Prepared in cooperation with the Southern Nevada Water Authority

\title{
Water-Surface Elevations, Discharge, and Water-Quality Data for Selected Sites in the Warm Springs Area near Moapa, Nevada
}

Open-Flle Report 2006-1311 



\section{Water-Surface Elevations, Discharge, and Water-Quality Data for Selected Sites in the Warm Springs Area near Moapa, Nevada}

By David A. Beck, Roslyn Ryan, Ronald J. Veley, Donald P. Harper, and Daron J. Tanko

Prepared in cooperation with the Southern Nevada Water Authority

Open-File Report 2006-1311 


\section{U.S. Department of the Interior DIRK KEMPTHORNE, Secretary}

\section{U.S. Geological Survey \\ Mark D. Myers, Director}

\section{U.S. Geological Survey, Reston, Virginia: 2006}

For product and ordering information:

World Wide Web: http://www.usgs.gov/pubprod

Telephone: 1-888-ASK-USGS

For more information on the USGS--the Federal source for science about the Earth, its natural and living resources, natural hazards, and the environment:

World Wide Web: http://www.usgs.gov

Telephone: 1-888-ASK-USGS

Any use of trade, product, or firm names is for descriptive purposes only and does not imply endorsement by the U.S. Government.

Although this report is in the public domain, permission must be secured from the individual copyright owners to reproduce any copyrighted materials contained within this report.

Suggested citation:

Beck, D.A., Ryan, R., Veley, R.J., Harper, D.P., and Tanko, D.J., 2006, Water-surface elevations, discharge, and waterquality data for selected sites in the Warm Springs area near Moapa, Nevada: U.S. Geological Survey Open-File Report 1311, 230 p. 


\section{Contents}

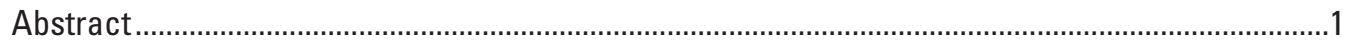

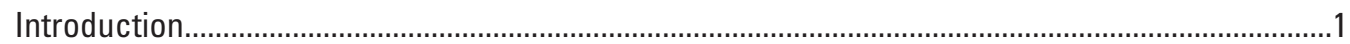

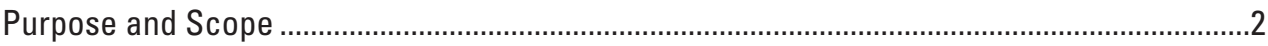

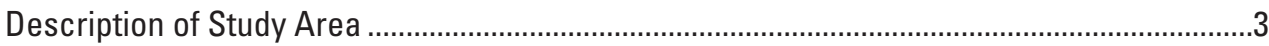

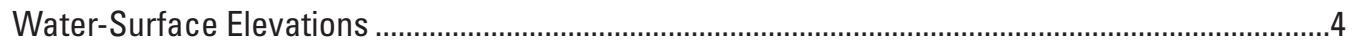

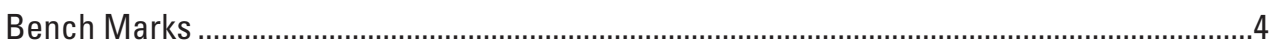

Reference Marks and Points ................................................................................................

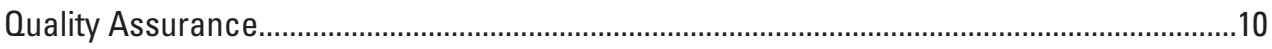

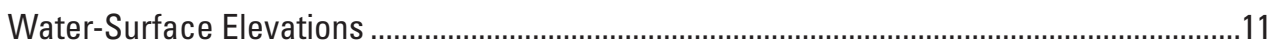

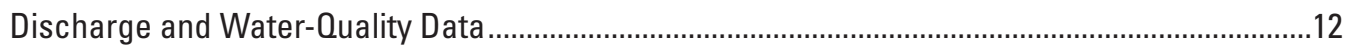

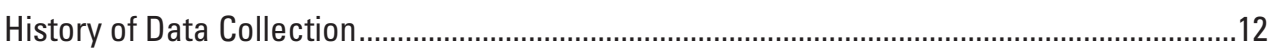

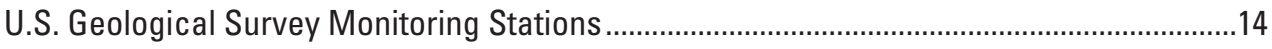

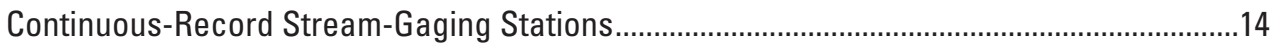

Partial-Record Stream-Gaging Stations .................................................................................14

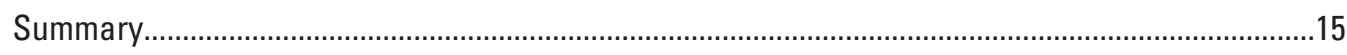

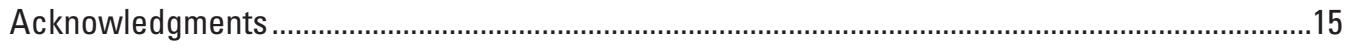

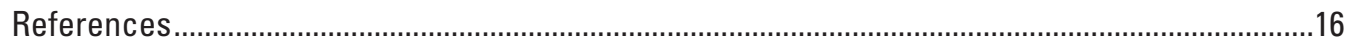

Appendix A. History of Water-Resources Development within the Warm Springs Area

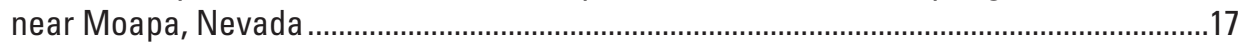

Appendix B. Water-Level, Discharge, and Water-Quality Data for Selected Monitoring Sites Within the Warm Springs Area near Moapa, Nevada .................................................35

Appendix C. National Geodetic Survey OPUS Solution Reports for Bench Marks Established in the Warm Springs Area near Moapa, Nevada............................................203

Appendix D. Discharge and Water-Quality Data Collected by the U.S. Geological Survey During September 10-12, 1963, in the Warm Springs Area near Moapa, Nevada............221

Appendix E. Discharge and Water-Quality Data Collected by the U.S. Geological Survey, U.S. Fish and Wildlife Service, Nevada Division of Water Resources, and Southern Nevada Water Authority on February 6-7, 2001, in the Warm Springs Area near Moapa, Nevada... 


\section{Figures}

Figure 1. Map showing location of study area and local features, Moapa Valley, Nevada ... 2

Figure 2. Map showing location of major spring groups, U.S. Geological Survey monitoring stations, and water-surface elevations on August 17, 2004, in the

Warm Springs area near Moapa, Nevada ...

Figure 3. Map showing location of permanent surface-elevation bench marks in the Warm Springs area near Moapa, Nevada

\section{Tables}

Table 1. Index to continuous-record and partial-record stream-gaging stations and miscellaneous sites in the Warm Springs area near Moapa, Nevada

Table 2. Elevation and location information for permanent land-surface bench marks in the Warm Springs area near Moapa, Nevada

Table 3. Elevations and descriptions of selected reference marks, points, and other features at continuous-recording and partial-record stations in the Warm Springs area near Moapa, Nevada

Table 4. Water-surface elevations measured on August 17, 2004, at continuousrecording and partial-record stations and miscellaneous sites in the Warm Springs area near Moapa, Nevada

\section{Conversion Factors, Datums, Discharge or Flow, Instantaneous Discharge, and Abbreviations and Acronyms}

Conversion Factors

\begin{tabular}{lcl}
\hline Multiply & By & To obtain \\
\hline acre & 4,047 & square meter \\
acre-foot (acre-ft) & 1,233 & cubic meter \\
centimeter $(\mathrm{cm})$ & 0.10 & millimeter \\
cubic foot per second $\left(\mathrm{ft}^{3} / \mathrm{s}\right)$ & 0.02832 & cubic meter per second \\
foot (ft) & 0.3048 & meter \\
inch (in.) & 2.54 & centimeter \\
mile (mi) & 1.609 & kilometer \\
square foot & 0.09290 & square meter \\
square mile $\left(\mathrm{mi}^{2}\right)$ & 2.590 & square kilometer \\
\hline
\end{tabular}

Temperature in degrees Celsius $\left({ }^{\circ} \mathrm{C}\right)$ may be converted to degrees Fahrenheit $\left({ }^{\circ} \mathrm{F}\right)$ as follows:

$$
{ }^{\circ} \mathrm{F}=\left(1.8 \times{ }^{\circ} \mathrm{C}\right)+32
$$

Temperature in degrees Fahrenheit $\left({ }^{\circ} \mathrm{F}\right)$ may be converted to degrees Celsius $\left({ }^{\circ} \mathrm{C}\right)$ as follows:

$$
{ }^{\circ} \mathrm{C}=\left({ }^{\circ} \mathrm{F}-32\right) / 1.8
$$




\section{Conversion Factors, Datums, Discharge or Flow, Instantaneous Discharge, and Abbreviations and Acronyms-Continued}

\section{Datums}

Vertical coordinate information is referenced to the North American Vertical Datum of 1988 (NAVD 88).

Horizontal coordinate information is referenced to the North American Datum of 1927 (NAD 27) and the North American Datum of 1983 (NAD 83).

Discharge or Flow

The rate that matter passes through a cross section of a stream channel or other water body per unit of time. The term commonly refers to the volume of water (including, unless otherwise stated, any sediment or other constituents suspended or dissolved in the water) that passes a cross section in a stream channel, flume, weir, canal, pipeline, etc., within a given period of time (cubic feet per second).

Instantaneous Discharge

The discharge at a particular instant of time (see also "Discharge").

Abbreviations and Acronyms

\begin{tabular}{ll}
\hline Abbreviations and Acronyms & Meaning \\
\hline BM & bench mark \\
DGPS & Differential Global Positioning System \\
DRI & Desert Research Institute \\
FWS & U.S. Fish and Wildlife Service \\
GPS & global positioning system \\
LVVWD & Las Vegas Valley Water District \\
MVID & Muddy Valley Irrigation District \\
MVWD & Moapa Valley Water District \\
NDWR & Nevada Division of Water Resources \\
NGS & National Geodetic Survey \\
NPC & Nevada Power Company \\
NWIS & National Water Information System \\
OPUS & Online Positioning User Service \\
Reclamation & Bureau of Reclamation \\
RM & reference mark \\
RP & reference point \\
SNWA & Southern Nevada Water Authority \\
UNAES & University of Nevada Agricultural Experiment station \\
USGS & U.S. Geological Survey \\
UTM & Universal Transverse Mercator \\
\hline
\end{tabular}


This page left intentionally blank. 


\title{
Water-Surface Elevations, Discharge, and Water-Quality Data for Selected Sites in the Warm Springs Area near Moapa, Nevada
}

\author{
By David A. Beck, Roslyn Ryan, Ronald J. Veley, Donald P. Harper, and Daron J. Tanko
}

\section{Abstract}

The U.S. Geological Survey, in cooperation with Southern Nevada Water Authority and the Nevada Division of Water Resources, operates and maintains a surface-water monitoring network of 6 continuous-record stream-flow gaging stations and 11 partial-record stations in the Warm Springs area near Moapa, Nevada. Permanent land-surface bench marks were installed within the Warm Springs area by the Las Vegas Valley Water District, the Southern Nevada Water Authority, and the U.S. Geological Survey to determine water-surface elevations at all network monitoring sites. Vertical datum elevation and horizontal coordinates were established for all bench marks through a series of Differential Global Positioning System surveys. Optical theodolite surveys were made to transfer Differential Global Positioning System vertical datums to reference marks installed at each monitoring site. The surveys were completed in June 2004 and watersurface elevations were measured on August 17, 2004. Watersurface elevations ranged from 1,810.33 feet above North American Vertical Datum of 1988 at a stream-gaging station in the Pederson Springs area to 1,706.31 feet at a station on the Muddy River near Moapa.

Discharge and water-quality data were compiled for the Warm Springs area and include data provided by the U.S. Geological Survey, Nevada Division of Water Resources, U.S. Fish and Wildlife Service, Moapa Valley Water District, Desert Research Institute, and Converse Consultants. Historical and current hydrologic data-collection networks primarily are related to changes in land- and water-use activities in the Warm Springs area. These changes include declines in ranching and agricultural use, the exportation of water to other areas of Moapa Valley, and the creation of a national wildlife refuge. Water-surface elevations, discharge, and water-quality data compiled for the Warm Springs area will help identify (1) effects of changing vegetation within the former agricultural lands, (2) effects of restoration activities in the wildlife refuge, and (3) potential impacts of ground-water withdrawals.

\section{Introduction}

The Warm Springs area, located in the northwestern end of Moapa Valley, Nev., (fig. 1) consists of a network of springs and seeps that form the headwaters of the Muddy River. Over time, this area has been home to the Anasazi and the Southern Paiute Indian tribes, outlaws, prospectors, Mormon settlers, and others (Baxter and Haworth, 1996; U.S. Fish and Wildlife, 1991). The availability of water has provided past and current inhabitants with the resource necessary to sustain life in a desert setting. In addition, nearby entities, such as the Moapa River Indian Reservation, the Moapa Valley Water District (MVWD), and the Nevada Power Company (NPC), use water obtained from the area. The Warm Springs area is home to the Moapa Valley National Wildlife Refuge. The refuge was established in 1979 to protect and secure the riparian habitat of an endangered native minnow, the Moapa dace (Moapa coriacea) (U.S. Fish and Wildlife, 1991). A brief history of water-resources development in the Warm Springs area is included in Appendix A.

The Warm Springs area is located approximately $60 \mathrm{mi}$ northeast of Las Vegas, which is one of the fastest growing metropolitan areas in the country. For more than 50 years, Las Vegas has used Lake Mead as its main source of drinking water. The ongoing growth of Las Vegas and the effects of the recent drought on the Colorado River have prompted water-resource managers to seek out and investigate additional sources of water. Presently (2006), the Nevada State Engineer is considering numerous applications to develop groundwater resources in basins adjacent to the upper Moapa Valley that would provide additional water to Las Vegas and Moapa Valley. It is not known what effects these proposed groundwater withdrawals will have on the riparian habitats and springs that form the Warm Springs area. Efforts are underway to acquire additional data to monitor for potential effects of these ground-water withdrawals. 


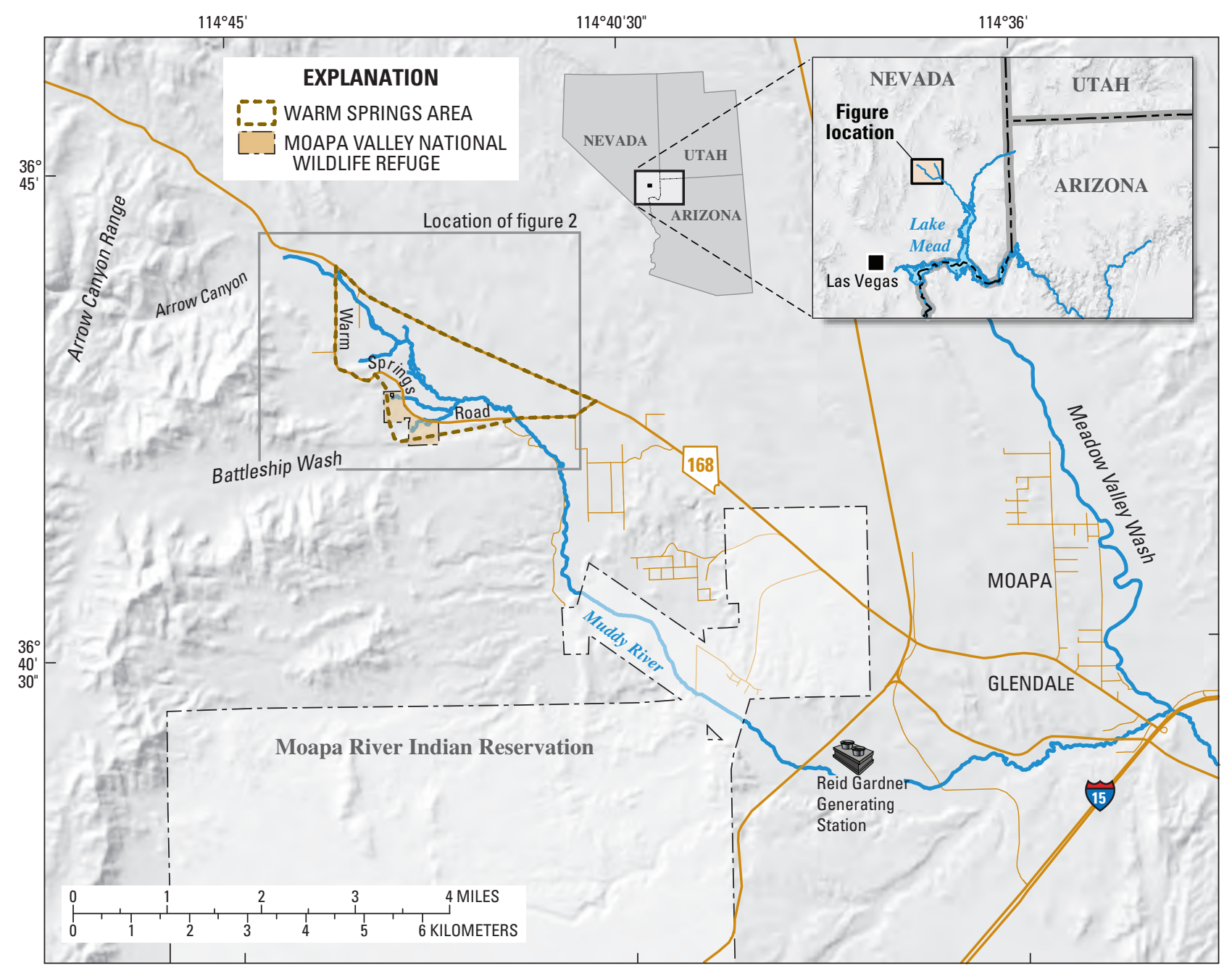

Figure 1. Location of study area and local features, Moapa Valley, Nevada.

As part of these efforts, the U.S. Geological Survey (USGS), in cooperation with the Southern Nevada Water Authority (SNWA), has completed a survey of water-surface elevations in the Warm Springs area. Bench marks (BMs), reference marks (RMs), reference points (RPs), and staff plates were established that will provide resource managers with tools to determine water-surface elevations at numerous monitoring sites in the area. These data will be used to assist in the efforts to determine what effects, if any, nearby groundwater withdrawals may have on the springs within the Warm Springs area.

\section{Purpose and Scope}

The primary purposes of this study are (1) to determine water-surface elevations in spring-fed pools and channels that currently are monitored by the USGS, and (2) to compile existing discharge and water-quality data within the Warm Springs area. For the purposes of this report, the Warm Springs area is defined as the area of the upper Moapa Valley upstream of the Muddy River Bridge at Warm Springs Road. The principle areas include the Muddy River flood plain and all the springs and seeps that are generally bounded by State Highway 168 and Warm Springs Road (fig. 2).

Permanent RMs and staff plates were installed near each of the hydrologic monitoring sites so that water-surface elevations could easily be obtained and related to land-surface datum. Land-surface datums used in this study were derived from permanent BMs established by the Las Vegas Valley Water District (LVVWD), SNWA, and USGS adjacent to the major spring groups and other monitoring sites. The elevations of these BMs were determined from a series of Differential Global Positioning System (DGPS) surveys. The elevations were transferred to the monitoring sites by optical theodolite surveys. 


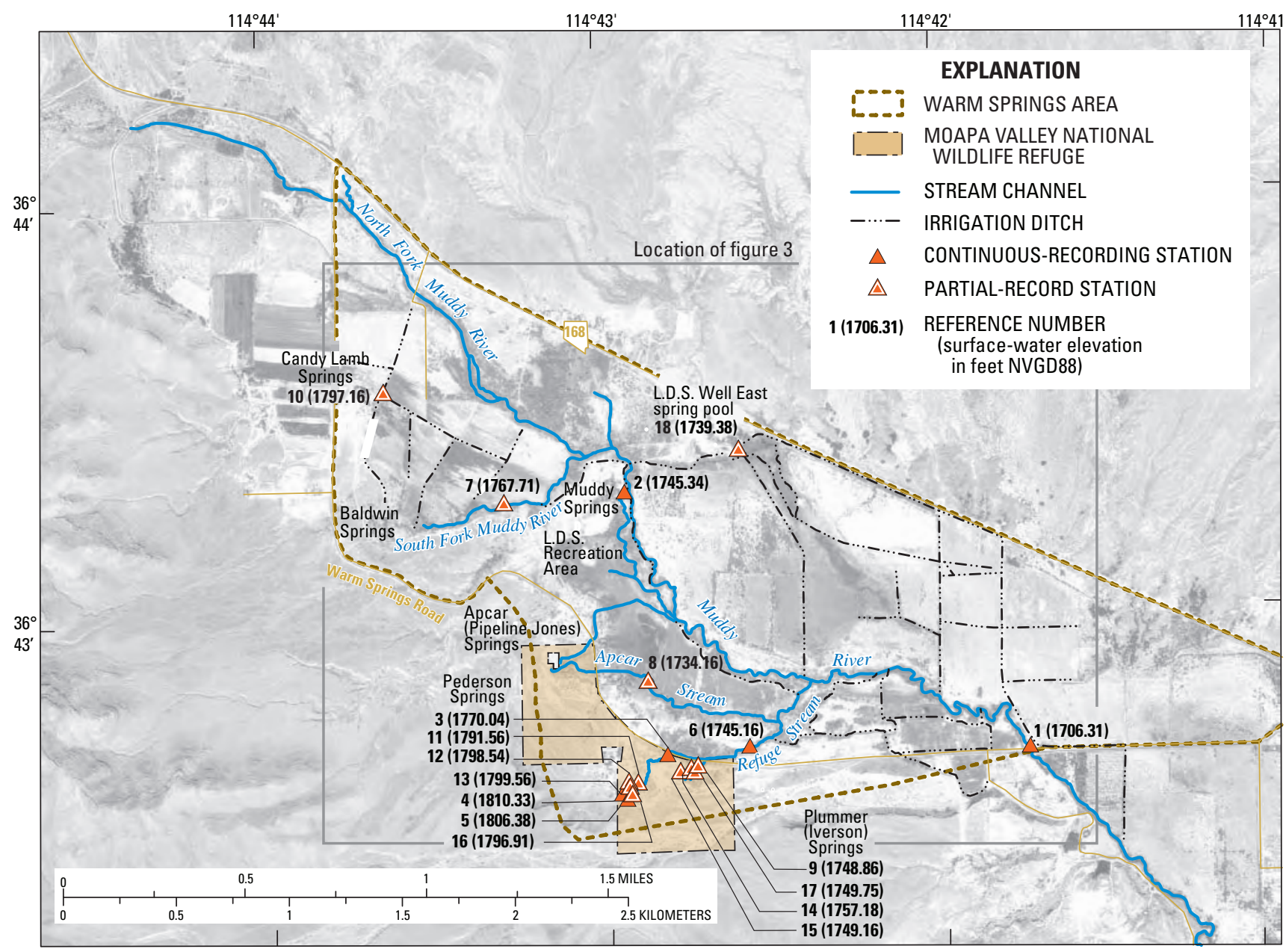

Figure 2. Location of major spring groups, U.S. Geological Survey monitoring stations, and water-surface elevations on August 17, 2004, in the Warm Springs area near Moapa, Nevada.

Existing discharge and water-quality data compiled for the Warm Springs area include data collected by the USGS and other agencies that manage, regulate, study, or use the water resources of the area. These data are included in this report, with measurements of water-surface elevations throughout the Warm Springs area made during this study, to support studies relating the condition of the springs to the regional ground-water flow system. Evaluation of the qualityassurance procedures for data collection by the other agencies is beyond the scope of this study. As a result, the USGS cannot verify the accuracy of the data provided.

As a supplement to data compilation, compendiums of water-resources development and data-collection networks are presented. Historical perspectives were based on (1) available data and references, (2) telephone interviews with many government and municipal officials, and (3) personal interviews with long-term residents within the Warm Springs area. Inclusion of the two compendiums in this report is intended to relate the historical development of the hydrologic monitoring network with land- and water-use changes in Moapa Valley.

\section{Description of Study Area}

The Warm Springs area, also known as the Muddy Springs area, is a network of springs and seeps that are located along the northeast slope of the Arrow Canyon Range (fig. 1). The area is bounded by Highway 168 to the north and northeast, Battleship Wash to the south, and Warm Springs Road to the west and southeast (fig. 1). There are six major spring groups within the study area that are generally aligned in a northwest-southeast direction: Cardy Lamb, Baldwin, Apcar, Muddy, Pederson, and Plummer (fig. 2). An unnamed spring area is located adjacent to Highway 168 near L.D.S. East well (fig 2, site 18); however, flow from this area discharges only intermittently. 
The Warm Springs area is located near the southern boundary of the White River ground-water flow system (Prudic and others, 1995). Discharge from the springs and seeps of the Warm Springs area is believed to be the largest and most southerly outflow from this ground-water system (Eakin, 1966). The physiography of the study area is characterized by north-trending mountains to the west and a broad alluvial basin to the east. The topography consists of normal-faulted terrains that form complex, heterogeneous geologic settings with unique local and regional characteristics.

The primary aquifers in the area generally are made up of carbonate rocks of Paleozoic age and sedimentary rocks of Tertiary age. The carbonate rocks form complex aquifers whose extents and thicknesses are largely unknown. These aquifers interconnect with aquifers of other rock types and, where deformed or fractured, have the potential to transmit ground water (Prudic and others, 1995).

The climate of the area is semiarid to arid with approximately $5 \mathrm{in}$. of annual precipitation, low humidity, and high evapotranspiration rates (Eakin, 1966; Mozejko, 1981). Recharge to the ground-water system supplying the Warm Springs area is primarily from precipitation in the high mountain ranges in east-central Nevada (Eakin, 1966). Ground-water discharge within the Warm Springs area is from evaporation, transpiration by plants, and flow from the springs.

The discharge channels of springs in the area and the main stem of the Muddy River primarily are meandering and shallow and contain moderate amounts of fine silt and organic debris. Vegetation within and along the channel banks include cattails (Typha spp.), willows (Salix spp.), mesquite (Prosopis pubescens), reeds, and non-native palm trees (Washingtonia filifera and Phoenix dactylifera) and Tamarisk (Tamarix spp.). Aquatic plants such as algae, spike rush (Eleocharis spp.), water nymph (Najas spp.), watercress (Nasturtium spp.), pondweed (Potamogeton spp.), and non-native eel grass (Vallisneria spp.) are abundant in most spring pools and slack water areas (Mozejko, 1981; U.S. Fish and Wildlife Service, 1995).

The Warm Springs area is home to numerous birds, mammals, and reptiles, including quail (Callipepla gambelii), roadrunners (Geococcyx californianus), songbirds, shorebirds, cottontail rabbits (Sylvilagus spp.), coyotes (Canis latrans), foxes, spiny soft-shell turtles (Amyda spinifera), and snakes. In addition to the aforementioned endangered Moapa dace, several other species in the area's waterways are listed as sensitive. These include the Moapa White River springfish (Crenichthys baileyi moapae), Moapa pebblesnail (Fluminicola avernalis), and the Moapa Warm Spring riffle beetle (Stenelmis moapa) (U.S. Fish and Wildlife Service, 1991, 1995).

\section{Water-Surface Elevations}

The USGS, in cooperation with SNWA and Nevada Division of Water Resources (NDWR), operates and maintains a surface-water network of 6 continuous-record stream-gaging stations and 11 partial-record stations in the Warm Springs area near Moapa, Nev. (table 1). To determine the elevation of the water surface at each monitoring site, BMs, RMs, and RPs were established at strategic locations within the Warm Springs area. For this report, a BM is defined as a permanent marker that was installed in the ground or on a structure and that has an established elevation based on the North American Vertical Datum of 1988 (NAVD 88). The elevations of these markers were derived from survey-grade differential global positioning system (GPS) instrumentation. A RM is defined as a permanent marker installed in the ground or on a structure in the vicinity of a gaging station. The elevations of the RMs were determined by optical theodolite surveys from a nearby bench mark. A RP is a permanent marker installed on a structure at a gaging station that allows direct measurement of water-surface elevation using a graduated measuring tape or ruler. The elevation of the RP also is determined by optical theodolite survey from a nearby bench mark. The elevations of the RMs and RPs in this report also were based on the NAVD 88.

Water-surface elevations at each of the monitoring stations were determined by reading the water level (stage) at the staff plate installed at each site. The elevation of each staff plate was determined from optical theodolite survey using nearby reference marks as control. Because staff plates have their own scale, the elevation of a water surface is obtained by converting stage value to differential GPS elevation.

\section{Bench Marks}

Permanent land-surface BMs used for this study were established by the LVVWD, Stantec (on contract with SNWA), and the USGS. BMs consist of either brass plates, steel bolts, or rebar set in concrete structures or survey-grade earth anchors. Photographs and descriptions of selected BMs used for this study are included in Appendix B and table 2, respectively. The locations of these BMs were selected on the basis of the long-term stability of the area or of the structure a BM was installed on and the proximity of each BM to each of the monitoring sites. The location of each BM is shown in figure 3. 
Table 1. Index to continuous-record and partial-record stream-gaging stations and miscellaneous sites in the Warm Springs area near Moapa, Nevada.

[Map site numbers for station locations are shown on figure 2. Latitude and longitude are shown in degrees, minutes, and seconds. Abbreviations: USGS, U.S. Geological Survey; NAD27, North American Vertical Datum of 1927; NV, Nevada; ft, foot]

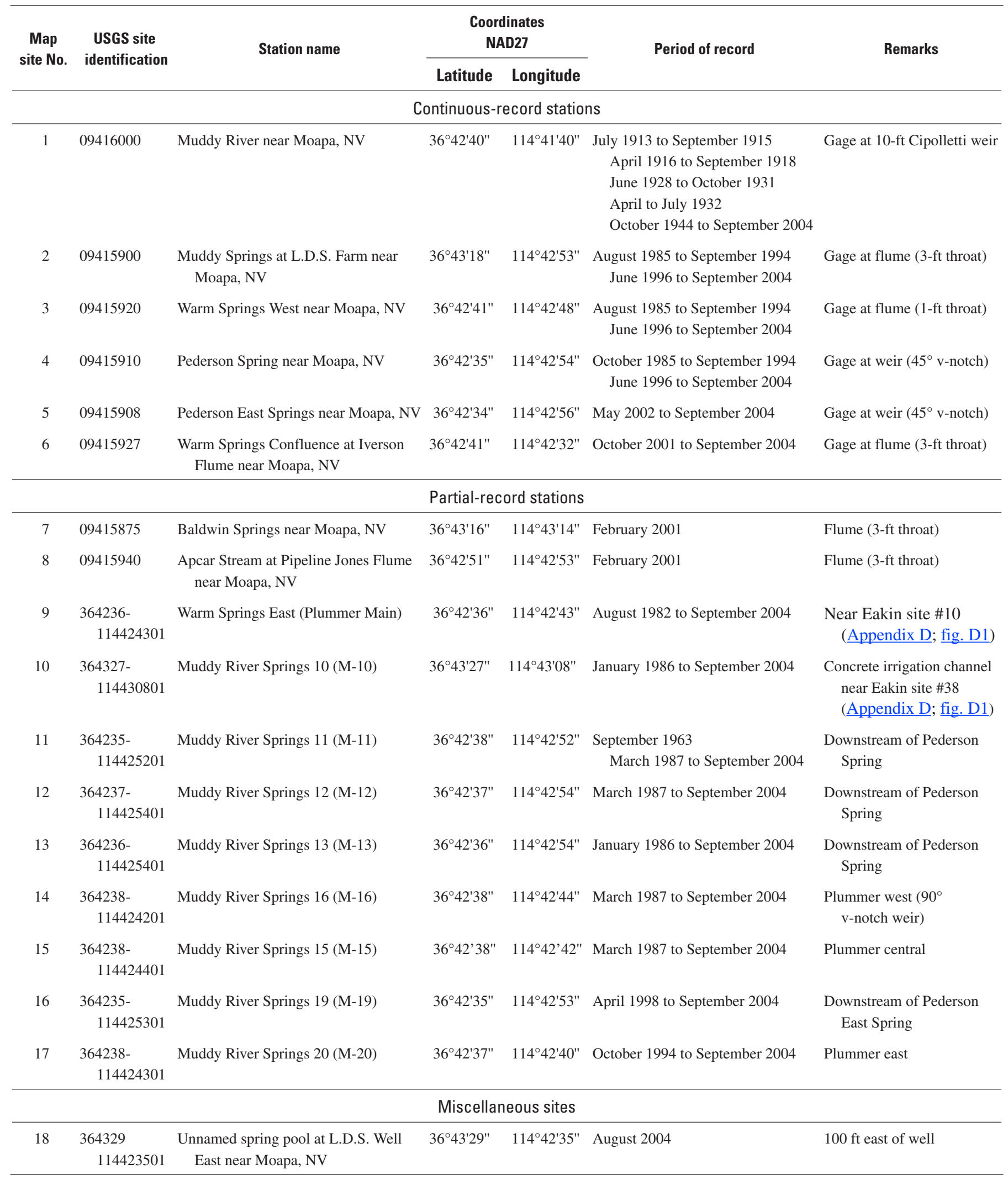


Table 2. Elevation and location information for permanent land-surface bench marks in the Warm Springs area near Moapa, Nevada.

[Map site numbers for bench mark locations are shown on figure 3. Elevation Ortho height is referenced to the North American Vertical Datum of 1988. Latitude and longitude are shown in degrees, minutes, and seconds. Occupation time: time, in hours, Global Positioning System was set up over a bench mark. Abbreviations: NAD 83, North American Datum of 1983; OPUS, Online Positioning User Service; USGS, U.S. Geological Survey; LVVWD, Las Vegas Valley Water District]

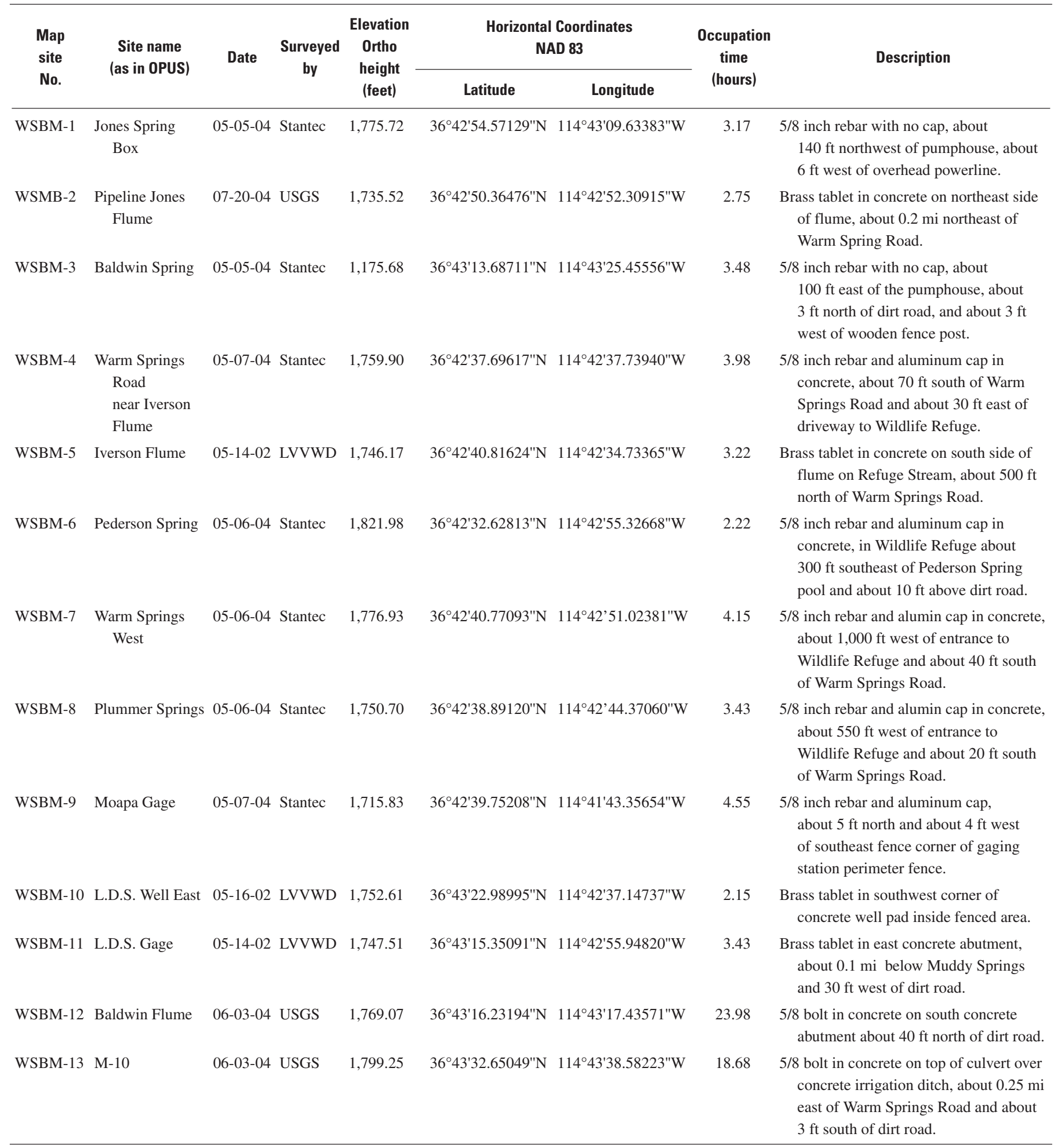




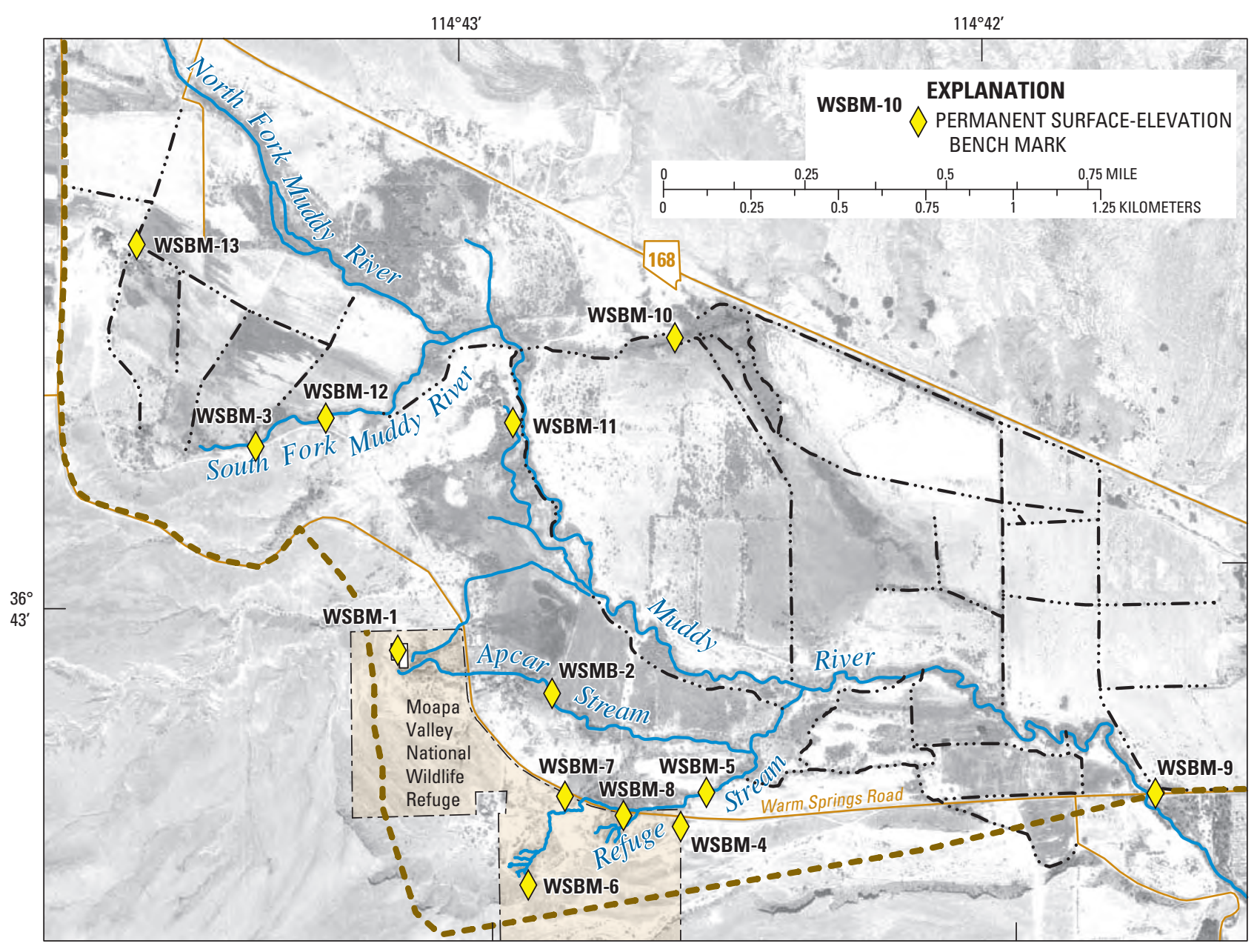

Figure 3. Location of permanent surface-elevation bench marks in the Warm Springs area near Moapa, Nevada.

Elevations and latitudes and longitudes for all the BMs in the study area were determined by applying DGPS surveying methods. The surveys consisted of setting up survey-grade DGPS equipment over each BM and processing the data through a National Geodetic Survey (NGS) web site. Equipment used by the LVVWD and Stantec and by the USGS for these surveys were the Trimble $5700^{\mathrm{TM}}$ and Ashtech ZExtreme ${ }^{\mathrm{TM}}$, respectively. According to manufacturer specifications, the relative accuracies of these units are $1 \mathrm{~cm}$ in the horizontal and $2 \mathrm{~cm}$ in the vertical.

The DGPS surveys of the study area ranged from just over 2 hours to almost 24 hours (table 2). When completed, the survey data were sent to the NGS Online Positioning User Service (OPUS) web site at http://www.ngs.noaa. gov/OPUS/. The GPS data files were then processed by OPUS using NGS computers and software to determine a BM positioning. The returned product, called the NGS OPUS Solution Report, lists the vertical datum, horizontal coordinates, and other related information. The accuracy of the OPUS corrected data is included with each individual sheet
(Dave Doyle, National Geodetic Survey, oral commun., 2004). The vertical datum and horizontal coordinates for each BM are summarized in table 2. Copies of the OPUS Solution Reports are included in Appendix C.

BMs at Jones Spring Box (WSBM-1), Baldwin Spring (WSBM-3), and Warm Springs Road near Iverson flume (WSBM-4) are included in table 2 and figure 3 but were not used to determine RM elevations at USGS monitoring sites for this study. They are included in this report to document their location in the event other BMs are destroyed.

\section{Reference Marks and Points}

Following the installation and survey of the land-surface BMs in the Warm Springs area, permanent RMs or RPs were established at each of the current USGS monitoring sites. Existing or new RMs established at continuous-record stream gages typically included brass monuments or anchor bolts embedded in concrete-filled areas or on other stable structures adjacent to the site. 
For the partial-record stations, staff plates were installed in the channel reaches where discharge measurements are periodically made. If there was no existing RM near the periodic site, fence posts were hammered into both banks of the channel. Where staff plates could not be installed, such as at site M-10, a RP with a 3/8-in. bolt was set into the vertical headwall of the culvert. The elevation of the water surface was then determined by measuring from the RP to the water surface using a graduated tape or ruler. Elevations and descriptions of the RMs and RPs for each site are given in table 3. Photographs of selected RMs and RPs are included in Appendix B for each site.

In addition to the RMs and RPs, optical theodolite surveys were done at each staff plate and at the top corners of each flume or weir. These additional points were surveyed to document the current conditions of existing structures and to help track changes that may occur in the future. This information also is included in table 3 .

Optical theodolite surveys were used to transfer BM datum (NAVD 88) to the permanent RMs and RPs established at all the current monitoring sites. A detailed description of the concepts and procedures of optical theodolite surveying is given by Kennedy (1988). The identification number of the BM used for each survey is shown in table 3. The approximate locations of the BM relative to the USGS monitoring sites are shown in Appendix B.

The equipment used to complete the optical theodolite surveys included an engineer's automatic, or self-leveling, instrument and a "Frisco-style" aluminum rod. The precision and accuracy for each survey were in accordance with procedures described by Kennedy (1988).

Table 3. Elevations and descriptions of selected reference marks, points, and other features at continuous-recording and partialrecord stations in the Warm Springs area near Moapa, Nevada.

[Map site numbers for station locations are shown on figure 2. Reference mark-item: RM-1, reference mark 1; RP-1, reference point 1; PZF, point of zero flow; F-1, top edge number 1 of a flume; W-1, top edge number 1 of a weir. Land-surface benchmark used: See table 1. Abbreviations: USGS, U.S. Geological Survey; NAD 83, North American Datum of 1983; NV, Nevada; ft, foot]

\begin{tabular}{|c|c|c|c|c|c|c|c|}
\hline $\begin{array}{l}\text { Map } \\
\text { site } \\
\text { No. }\end{array}$ & $\begin{array}{l}\text { USGS site } \\
\text { identifi- } \\
\text { cation No. }\end{array}$ & Station name & $\begin{array}{l}\text { Date } \\
\text { surveyed }\end{array}$ & $\begin{array}{l}\text { Reference } \\
\text { mark-item }\end{array}$ & $\begin{array}{c}\text { Elevation } \\
\text { NAD } 83 \\
\text { (feet) }\end{array}$ & $\begin{array}{c}\text { Land- } \\
\text { surface } \\
\text { benchmark } \\
\text { used }\end{array}$ & Description \\
\hline \multicolumn{8}{|c|}{ Continuous-recording stations } \\
\hline \multirow[t]{6}{*}{1} & 9416000 & $\begin{array}{l}\text { Muddy River near } \\
\text { Moapa, NV }\end{array}$ & $06-02-04$ & RM-1 & $1,709.68$ & WSBM-9 & Top of eyebolt on top of left bank wingwall above staff plate. \\
\hline & & & & RM-5 & $1,717.23$ & WSBM-9 & $\begin{array}{l}\text { Top center of "I" beam on top of wall on left bank downstream of } \\
\text { gage house. }\end{array}$ \\
\hline & & & & RM-6 & $1,717.67$ & WSBM-9 & Top of 2-inch pipe at the northeast corner of gage house platform. \\
\hline & & & & RM-7 & $1,719.74$ & WSBM-9 & $\begin{array}{l}\text { Top of large bolt securing Nevada Power } \\
\text { large white pipe along fence on left bank. }\end{array}$ \\
\hline & & & & RP-1 & $1,706.69$ & WSBM-9 & Top of fence post at left edge of water below gage house. \\
\hline & & & & Staff plate & $1,709.04$ & WSBM-9 & Top of staff plate $(3.34 \mathrm{ft})$ \\
\hline \multirow[t]{10}{*}{2} & 9415900 & $\begin{array}{l}\text { Muddy Springs at } \\
\text { L.D.S. Farm near }\end{array}$ & 06-03-04 & RM-3 & $1,745.42$ & WSBM-11 & $\begin{array}{l}\text { Top of 2-inch PVC pipe at downstream right-bank concrete } \\
\text { abutment wall. }\end{array}$ \\
\hline & & Moapa, NV & & RM-4 & $1,747.25$ & WSBM-11 & $\begin{array}{l}\text { Center round of the " } 9 \text { " in "93" written in the concrete abutment } \\
\text { on the right bank. }\end{array}$ \\
\hline & & & & RM-5 & $1,753.55$ & WSBM-11 & Chiseled square in concrete slab on walkway to gage. \\
\hline & & & & RP-1 & $1,747.93$ & WSBM-11 & Top of upstream right-bank edge of flume. \\
\hline & & & & RP-2 & $1,746.97$ & WSBM-11 & Nail in staff-plate backboard. \\
\hline & & & & PZF & $1,744.93$ & WSBM-11 & Bottom of upstream end of flume. \\
\hline & & & & F-1 & $1,748.04$ & WSBM-11 & Downstream right-bank top edge of flume. \\
\hline & & & & $\mathrm{F}-2$ & $1,748.13$ & WSBM-11 & Upstream right-bank top edge of flume. \\
\hline & & & & F-3 & $1,748.06$ & WSBM-11 & Downstream left-bank top edge of flume. \\
\hline & & & & $\mathrm{F}-4$ & $1,748.11$ & WSBM-11 & Upstream left-bank top edge of flume. \\
\hline \multirow[t]{8}{*}{3} & 9415920 & Warm Springs West near & 06-03-04 & RM-1 & $1,772.94$ & WSBM-7 & Painted circle on rock wall above gage. \\
\hline & & Moapa, NV & & RM-3 & $1,770.78$ & WSBM-7 & $\begin{array}{l}\text { Upstream streamward corner of concrete pad on left bank (no } \\
\text { mark). }\end{array}$ \\
\hline & & & & PZF & $1,769.12$ & WSBM-7 & Bottom of upstream end of flume. \\
\hline & & & & $\mathrm{F}-1$ & $1,772.30$ & WSBM-7 & Upstream left-bank top edge of flume. \\
\hline & & & & $\mathrm{F}-2$ & $1,772.31$ & WSBM-7 & Downstream left-bank top edge of flume. \\
\hline & & & & F-3 & $1,772.33$ & WSBM-7 & Downstream right-bank top edge of flume. \\
\hline & & & & F-4 & $1,772.27$ & WSBM-7 & Upstream right-bank top edge of flume. \\
\hline & & & & Staff plate & $1,772.13$ & WSBM-7 & Top of staff plate $(3.00 \mathrm{ft})$ \\
\hline
\end{tabular}


Table 3. Elevations and descriptions of selected reference marks, points, and other features at continuous-recording and partialrecord stations in the Warm Springs area near Moapa, Nevada.-Continued

[Map site numbers for station locations are shown on figure 2. Reference mark-item: RM-1, reference mark 1; RP-1, reference point 1; PZF, point of zero flow; F-1, top edge number 1 of a flume; W-1, top edge number 1 of a weir. Land-surface benchmark used: See table 1. Abbreviations: USGS, U.S. Geological Survey; NAD 83, North American Datum of 1983; NV, Nevada; ft, foot]

\begin{tabular}{|c|c|c|c|c|c|c|c|}
\hline $\begin{array}{l}\text { Map } \\
\text { site } \\
\text { No. }\end{array}$ & $\begin{array}{l}\text { USGS site } \\
\text { identifi- } \\
\text { cation No. }\end{array}$ & Station name & $\begin{array}{c}\text { Date } \\
\text { surveyed }\end{array}$ & $\begin{array}{l}\text { Reference } \\
\text { mark-item }\end{array}$ & $\begin{array}{c}\text { Elevation } \\
\text { NAD } 83 \\
\text { (feet) }\end{array}$ & $\begin{array}{c}\text { Land- } \\
\text { surface } \\
\text { benchmark } \\
\text { used }\end{array}$ & Description \\
\hline \multicolumn{8}{|c|}{ Continuous-recording stations-Continued } \\
\hline \multirow[t]{5}{*}{4} & 9415910 & $\begin{array}{l}\text { Pederson Spring near } \\
\text { Moapa, NV }\end{array}$ & 06-09--04 & RM-4 & $1,809.32$ & WSBM-6 & $\begin{array}{l}\text { Brass tablet in concrete in cylinder in ground, about } 40 \mathrm{ft} \\
\text { northwest of spring pool. }\end{array}$ \\
\hline & & & & RM-5 & $1,814.04$ & WSBM-6 & $\begin{array}{l}\text { Brass tablet in concrete in cylinder in ground, about } 45 \mathrm{ft} \text { east of } \\
\text { spring pool. }\end{array}$ \\
\hline & & & & RM-6 & $1,810.95$ & WSBM-6 & Top of anchor bolt on left bank (west) concrete wall. \\
\hline & & & & PZF & $1,809.82$ & WSBM-6 & Notch apex of weir plate. \\
\hline & & & & Staff plate & $1,812.22$ & WSBM-6 & Top of staff plate $(6.74 \mathrm{ft})$ \\
\hline \multirow[t]{5}{*}{5} & 9415908 & $\begin{array}{l}\text { Pederson East Spring near } \\
\text { Moapa, NV }\end{array}$ & 06-09-04 & RM-2 & $1,807.73$ & WSBM-6 & $\begin{array}{l}\text { Top of anchor bolt on west side of spring pool } \\
\text { that anchors steel supports for gage house. }\end{array}$ \\
\hline & & & & RM-3 & $1,807.62$ & WSBM-6 & $\begin{array}{l}\text { Brass tablet on top of upstream end of left-bank } \\
\text { concrete wall. }\end{array}$ \\
\hline & & & & RP-1 & $1,807.25$ & WSBM-6 & $\begin{array}{l}\text { Nail in staff plate backboard on left bank weir } \\
\text { wall. }\end{array}$ \\
\hline & & & & $\mathrm{PZF}$ & $1,806.04$ & WSBM-6 & Notch apex of weir plate. \\
\hline & & & & Staff plate & $1,807.59$ & WSBM-6 & Top of staff plate $(6.74 \mathrm{ft})$ \\
\hline \multirow[t]{9}{*}{6} & 9415927 & Warm Springs Confluence & 06-03-04 & RM-2 & $1,747.50$ & WSBM-5 & "X" on the L bracket. \\
\hline & & $\begin{array}{l}\text { at Iverson Flume near } \\
\text { Moapa, NV }\end{array}$ & & RM-3 & $1,746.58$ & WSBM-5 & $\begin{array}{l}\text { Top of 1-2-inch concrete anchor bolt on left } \\
\text { bank. }\end{array}$ \\
\hline & & & & RP-1 & $1,747.89$ & WSBM-5 & Top of upstream staff plate $(10.14 \mathrm{ft})$ \\
\hline & & & & RP-2 & $1,747.89$ & WSBM-5 & Top of downstream staff plate $(10.14 \mathrm{ft})$. \\
\hline & & & & PZF & $1,744.45$ & WSBM-5 & Bottom of upstream end of flume. \\
\hline & & & & F-1 & $1,747.65$ & WSBM-5 & Upstream right-bank top edge of flume. \\
\hline & & & & $\mathrm{F}-2$ & $1,747.63$ & WSBM-5 & Upstream left-bank top edge of flume. \\
\hline & & & & $\mathrm{F}-3$ & $1,747.59$ & WSBM-5 & Downstream left-bank top edge of flume. \\
\hline & & & & F-4 & $1,747.60$ & WSBM-5 & Downstream right bank top edge of flume. \\
\hline \multicolumn{8}{|c|}{ Partial-record stations } \\
\hline \multirow[t]{9}{*}{7} & 9415875 & $\begin{array}{l}\text { Baldwin Springs near } \\
\text { Moapa, NV }\end{array}$ & 06-02-04 & RM-1 & $1,769.04$ & WSBM-12 & $\begin{array}{l}\text { 3-8-inch bolt in middle of concrete abutment } \\
\text { on left bank. }\end{array}$ \\
\hline & & & & $\mathrm{RM}-2$ & $1,771.83$ & WSBM-12 & Top of fence post, 10 feet south of flume. \\
\hline & & & & RM-3 & $1,776.62$ & WSBM-12 & $\begin{array}{l}\text { Top edge of } 3-8 \text { inch lag bolt set horizontal in } \\
\text { railroad-tie fence post, about } 40 \mathrm{ft} \text { south of flume. }\end{array}$ \\
\hline & & & & PZF & $1,767.42$ & WSBM-12 & Bottom of upstream end of flume. \\
\hline & & & & F-1 & $1,770.61$ & WSBM-12 & Upstream left-bank top edge of flume. \\
\hline & & & & $\mathrm{F}-2$ & $1,770.58$ & WSBM-12 & Upstream right-bank top edge of flume. \\
\hline & & & & $\mathrm{F}-3$ & $1,770.57$ & WSBM-12 & Downstream left-bank top edge of flume. \\
\hline & & & & F-4 & $1,770.59$ & WSBM-12 & Downstream right-bank top edge of flume. \\
\hline & & & & Staff plate & $1,769.31$ & WSBM-12 & Top of staff plate $(27.14 \mathrm{ft})$ \\
\hline \multirow[t]{8}{*}{8} & 9415940 & $\begin{array}{l}\text { Apcar Stream at Pipeline } \\
\text { Jones Flume near }\end{array}$ & 07-20-04 & RM-1 & $1,735.19$ & WSBM-2 & $\begin{array}{l}\text { 5-8-inch bolt in downstream end of concrete } \\
\text { abutment on right bank. }\end{array}$ \\
\hline & & Moapa, NV & & RM-2 & $1,735.33$ & WSBM-2 & $\begin{array}{l}\text { 5-8-inch bolt in upstream end of concrete } \\
\text { abutment on right bank. }\end{array}$ \\
\hline & & & & PZF & $1,733.48$ & WSBM-2 & Bottom of upstream end of flume. \\
\hline & & & & $\mathrm{F}-1$ & $1,736.47$ & WSBM-2 & Upstream left-bank top edge of flume. \\
\hline & & & & $\mathrm{F}-2$ & $1,736.49$ & WSBM-2 & Upstream right-bank top edge of flume. \\
\hline & & & & $\mathrm{F}-3$ & $1,736.51$ & WSBM-2 & Downstream left-bank top edge of flume. \\
\hline & & & & F-4 & $1,736.49$ & WSBM-2 & Downstream right-bank top edge of flume. \\
\hline & & & & Staff plate & $1,736.79$ & WSBM-2 & Top of staff plate $(3.34 \mathrm{ft})$ \\
\hline
\end{tabular}


Table 3. Elevations and descriptions of selected reference marks, points, and other features at continuous-recording and partialrecord stations in the Warm Springs area near Moapa, Nevada.-Continued

[Map site numbers for station locations are shown on figure 2. Reference mark-item: RM-1, reference mark 1; RP-1, reference point 1; PZF, point of zero flow; F-1, top edge number 1 of a flume; W-1, top edge number 1 of a weir. Land-surface benchmark used: See table 1. Abbreviations: USGS, U.S. Geological Survey; NAD 83, North American Datum of 1983; NV, Nevada; ft, foot]

\begin{tabular}{|c|c|c|c|c|c|c|c|}
\hline $\begin{array}{l}\text { Map } \\
\text { site } \\
\text { No. }\end{array}$ & $\begin{array}{l}\text { USGS site } \\
\text { identifi- } \\
\text { cation No. }\end{array}$ & Station name & $\begin{array}{l}\text { Date } \\
\text { surveyed }\end{array}$ & $\begin{array}{l}\text { Reference } \\
\text { mark-item }\end{array}$ & $\begin{array}{l}\text { Elevation } \\
\text { NAD } 83 \\
\text { (feet) }\end{array}$ & $\begin{array}{l}\text { Land- } \\
\text { surface } \\
\text { benchmark } \\
\text { used }\end{array}$ & Description \\
\hline \multicolumn{8}{|c|}{ Partial-record stations-Continued } \\
\hline \multirow[t]{2}{*}{9} & \multirow[t]{2}{*}{$\begin{array}{l}364236- \\
114424301\end{array}$} & \multirow[t]{2}{*}{$\begin{array}{l}\text { Warm Springs East } \\
\text { (Plummer Main) }\end{array}$} & \multirow[t]{2}{*}{ 06-10-04 } & RM-1 & $1,751.08$ & WSBM-8 & $\begin{array}{l}\text { Top of well casing on right bank of Plummer } \\
\text { Main, about } 15 \mathrm{ft} \text { southwest of gage. }\end{array}$ \\
\hline & & & & Staff plate & $1,749.17$ & WSBM-8 & Top of staff plate (3.34 ft). \\
\hline \multirow[t]{4}{*}{10} & \multirow[t]{4}{*}{$\begin{array}{l}364327- \\
114430801\end{array}$} & \multirow[t]{4}{*}{$\begin{array}{l}\text { Muddy River Springs } 10 \\
\text { (M-10) }\end{array}$} & \multirow[t]{4}{*}{ 06-03-04 } & RM-1 & $1,799.46$ & WSBM-13 & $\begin{array}{l}\text { 3-8-inch bolt on top of concrete culvert, about } \\
15 \mathrm{ft} \text { northwest of bench mark. }\end{array}$ \\
\hline & & & & RM-2 & $1,800.51$ & WSBM-13 & $\begin{array}{l}\text { Nail in south side of telephone pole, about } 15 \mathrm{ft} \text { northwest of } \\
\text { bench mark. }\end{array}$ \\
\hline & & & & RP-1 & $1,798.38$ & WSBM-13 & 3-8-inch bolt in east face of concrete culvert. \\
\hline & & & & RP-2 & $1,799.12$ & WSBM-13 & $\begin{array}{l}\text { 3-8-inch bolt in north face of concrete culvert, } \\
\text { about } 15 \mathrm{ft} \text { northwest of bench mark. }\end{array}$ \\
\hline \multirow[t]{3}{*}{11} & \multirow{3}{*}{$\begin{array}{l}364235- \\
\quad 114425201\end{array}$} & \multirow{3}{*}{$\begin{array}{l}\text { Muddy River Springs } 11 \\
\qquad(\mathrm{M}-11)\end{array}$} & \multirow[t]{3}{*}{ 06-09-04 } & RM-1 & $1,795.09$ & WSBM-6 & Top of fence post on left bank. \\
\hline & & & & $\mathrm{RM}-2$ & $1,795.09$ & WSBM-6 & Top of fence post on right bank. \\
\hline & & & & Staff plate & $1,794.10$ & WSBM-6 & Top of staff plate (27.14 ft). \\
\hline \multirow[t]{3}{*}{12} & \multirow{3}{*}{$\begin{array}{l}364237- \\
\quad 114425401\end{array}$} & \multirow{3}{*}{$\begin{array}{l}\text { Muddy River Springs } 12 \\
\text { (M-12) }\end{array}$} & \multirow[t]{3}{*}{ 06-09-04 } & RM-1 & $1,801.76$ & WSBM-6 & Top of fence post on left bank. \\
\hline & & & & RM-2 & $1,801.49$ & WSBM-6 & Top of fence post on right bank. \\
\hline & & & & Staff plate & $1,801.22$ & WSBM-6 & Top of staff plate $(27.14 \mathrm{ft})$ \\
\hline \multirow[t]{3}{*}{13} & \multirow{3}{*}{$\begin{array}{l}364236- \\
114425401\end{array}$} & \multirow{3}{*}{$\begin{array}{l}\text { Muddy River Springs } 13 \\
\text { (M-13) }\end{array}$} & \multirow[t]{3}{*}{ 06-09-04 } & RM-1 & $1,802.83$ & WSBM-6 & Top of fence post on left bank. \\
\hline & & & & RM-2 & $1,804.33$ & WSBM-6 & Top of fence post on right bank. \\
\hline & & & & Staff plate & $1,801.91$ & WSBM-6 & Top of staff plate $(27.14 \mathrm{ft})$ \\
\hline \multirow[t]{4}{*}{14} & \multirow[t]{4}{*}{$\begin{array}{l}364238- \\
114424201\end{array}$} & \multirow{4}{*}{$\begin{array}{l}\text { Muddy River Springs } 16 \\
\quad \text { (Plummer } \\
\text { West) }\end{array}$} & \multirow[t]{4}{*}{ 06-10-04 } & RM-1 & $1,758.08$ & WSBM-8 & $\begin{array}{l}\text { Top of } 1 \text {-inch pipe in left bank, about } 20 \mathrm{ft} \\
\text { northeast of weir. }\end{array}$ \\
\hline & & & & W-1 & $1,757.37$ & WSBM-8 & Top of left-bank end of weir. \\
\hline & & & & $\mathrm{W}-2$ & $1,757.37$ & WSBM-8 & Top of right-bank end of weir. \\
\hline & & & & Staff plate & $1,757.79$ & WSBM-8 & Top of staff plate $(2.00 \mathrm{ft})$ \\
\hline \multirow[t]{2}{*}{15} & \multirow[t]{2}{*}{$\begin{array}{l}364238- \\
114424401\end{array}$} & \multirow[t]{2}{*}{$\begin{array}{l}\text { Muddy River Springs } 15 \\
\quad \text { (Plummer Central) }\end{array}$} & \multirow[t]{2}{*}{ 06-10-04 } & RM-1 & $1,753.55$ & WSBM-8 & $\begin{array}{l}\text { Top of fence post in concrete wall, about } 10 \mathrm{ft} \text { northwest of staff } \\
\text { plate. }\end{array}$ \\
\hline & & & & Staff plate & $1,751.24$ & WSBM-8 & Top of staff plate $(27.14 \mathrm{ft})$ \\
\hline \multirow[t]{3}{*}{16} & \multirow[t]{3}{*}{$\begin{array}{l}364235- \\
114425301\end{array}$} & $\begin{array}{l}\text { Muddy River Springs } 19 \\
\text { (M-19) }\end{array}$ & 06-09-04 & RM-1 & $1,800.88$ & WSBM-6 & Top of fence post on left bank. \\
\hline & & & & RM-2 & $1,800.96$ & WSBM-6 & Top of fence post on right bank. \\
\hline & & & & Staff plate & $1,799.51$ & WSBM-6 & Top of staff plate $(27.14 \mathrm{ft})$ \\
\hline 17 & $\begin{array}{l}364238- \\
\quad 114424301\end{array}$ & $\begin{array}{l}\text { Muddy River Springs } 20 \\
\text { (Plummer East) }\end{array}$ & 06-10-04 & RM-1 & $1,751.08$ & WSBM-8 & $\begin{array}{l}\text { Top of well casing on right bank of Plummer } \\
\text { Main, about } 15 \mathrm{ft} \text { southwest of staff plate. }\end{array}$ \\
\hline & & & & Staff plate & $1,751.84$ & WSBM-8 & Top of staff plate $(27.14 \mathrm{ft})$ \\
\hline
\end{tabular}

\section{Quality Assurance}

To ensure the accuracy of BM datums and coordinates, OPUS Solutions for each DGPS survey were run using the NGS GEOID configuration (1999 and 2003) for computing orthometric heights. In addition, three of the BMs—Jones Spring Box, Baldwin Spring, and L.D.S. gage were resurveyed by one of the other agencies. OPUS solution reports for these three sites are included in Appendix C.

LVVWD and Stantec surveyed Jones Spring Box at Apcar on February 6, 2004, and Baldwin springs near the pump house on May 5, 2004. Differences between the Jones Spring Box surveys were $2 \mathrm{~cm}$ in the vertical (orthometric height) and $3 \mathrm{~mm}$ in the north horizontal (UTM coordinate). 
Differences between the Baldwin Spring surveys were $1.4 \mathrm{~cm}$ in the vertical, $5 \mathrm{~mm}$ in the north horizontal, and $4 \mathrm{~mm}$ in the east horizontal (see OPUS reports, Appendix C).

Muddy Spring gage at L.D.S. Farm was surveyed by LVVWD and USGS on May 14, 2002, and June 2, 2004, respectively. Differences between the two surveys were $5 \mathrm{~mm}$ in the vertical, $2.1 \mathrm{~cm}$ in the north horizontal, and $5 \mathrm{~mm}$ in the east horizontal.

To ensure the accuracy of each optical theodolite survey, a series of operational checks were made on the instruments and rods. Visual inspections of equipment were made daily when in use, and peg tests were done to determine if instruments were in proper adjustment. A two-peg test was made before and after each series of levels. A complete description of the two-peg test procedure is given in a report by Kennedy (1988). At the same time the surveying instrument was peg-tested, the rod was checked by comparing it against an engineer's ruler.

\section{Water-Surface Elevations}

On August 17, 2004, water levels were obtained from the staff plates at all the USGS monitoring sites. The only exception was the water level at an unnamed spring-fed pool near well L.D.S Well East (fig. 2). The water-surface elevation of the pool which is located about $100 \mathrm{ft}$ east of the well was measured using the optical theodolite survey for the BM at the well. In early July 2004, flow was observed to be discharging from several pools in the area and flowing into the Muddy River. By August 17, 2004, most of the pools had completely dried up and water no longer discharged from the area. On October 1, 2004, water was observed to be emanating from the surveyed well pond and other nearby pools and discharging to the Muddy River.

The elevation of each water surface was adjusted to NAVD 88 using the results of the differential stadia surveys. The location and water-level elevations of the readings made on August 17, 2004, are shown on figure 2 and included in table 4.

Table 4. Water-surface elevations measured on August 17, 2004, at continuous-recording and partial-record stations and miscellaneous sites in the Warm Springs area near Moapa, Nevada.

[Map site numbers for station locations are shown on figure 2. Abbreviations: USGS, U.S. Geological Survey; NAD83, North American Vertical Datum of 1983; NV, Nevada; ft, foot]

\begin{tabular}{|c|c|c|c|c|}
\hline $\begin{array}{c}\text { Map } \\
\text { site No. }\end{array}$ & $\begin{array}{c}\text { USGS site } \\
\text { identification No. }\end{array}$ & Station name & $\begin{array}{l}\text { Staff plate } \\
\text { reading } \\
\text { (feet) }\end{array}$ & $\begin{array}{l}\text { Surface-water } \\
\text { elevation } \\
\text { NAD83 } \\
\text { (feet) }\end{array}$ \\
\hline \multicolumn{5}{|c|}{ Continuous-recording stations } \\
\hline 1 & 09416000 & Muddy River near Moapa, NV & 0.61 & $1,706.31$ \\
\hline 2 & 09415900 & Muddy Springs at L.D.S. Farm near Moapa, NV & .69 & $1,745.34$ \\
\hline 3 & 09415920 & Warm Springs West near Moapa, NV & .91 & $1,770.04$ \\
\hline 4 & 09415910 & Pederson Spring near Moapa, NV & 4.85 & $1,810.33$ \\
\hline 5 & 09415908 & Pederson East Spring near Moapa, NV & 5.54 & $1,806.38$ \\
\hline 6 & 09415927 & Warm Springs Confluence at Iverson Flume near Moapa, NV & 7.62 & $1,745.16$ \\
\hline \multicolumn{5}{|c|}{ Partial-record stations } \\
\hline 7 & 09415875 & Baldwin Springs Flume near Moapa, NV & 25.54 & $1,767.71$ \\
\hline 8 & 09415940 & Apcar Stream at Pipeline-Jones Flume near Moapa, NV & .71 & $1,734.16$ \\
\hline 9 & 364236114424301 & Warm Springs East (Plummer Main) & 3.03 & $1,748.86$ \\
\hline 10 & 364327114430801 & Muddy River Springs 10 (M-10) & ${ }^{1} 1.22$ & $1,797.16$ \\
\hline 11 & 364235114425201 & Muddy River Springs 11 (M-11) & 24.60 & $1,791.56$ \\
\hline 12 & 364237114425401 & Muddy River Springs 12 (M-12) & 24.46 & $1,798.54$ \\
\hline 13 & 364236114425401 & Muddy River Springs 13 (M-13) & 24.80 & $1,799.56$ \\
\hline 14 & 364238114424201 & Muddy River Springs 16 (Plummer West) & 1.40 & $1,757.18$ \\
\hline 15 & 364238114424401 & Muddy River Springs (Plummer Central) & 25.06 & $1,749.16$ \\
\hline 16 & 364235114425301 & Muddy River Springs 19 (M-19) & 24.55 & $1,796.91$ \\
\hline 17 & 364238114424301 & Muddy River Springs 20 (M-20) & 25.05 & $1,749.75$ \\
\hline \multicolumn{5}{|c|}{ Miscellaneous sites } \\
\hline 18 & & Unnamed spring pool at L.D.S. East Well near Moapa, NV & & ${ }^{2} 1,739.38$ \\
\hline
\end{tabular}

${ }^{1}$ Reading is the distance from the reference point (RP) down to the water surface in the channel.

${ }^{2}$ Determined by optical theodolite survey from bench mark WSBM-10. 


\section{Discharge and Water-Quality Data}

\section{History of Data Collection}

In July 1913, the first continuous-record stream-gaging station was established in the Warm Springs area by the Muddy Valley Irrigation District (MVID). The gage was constructed near its current location just upstream from the culvert at Warm Springs Road (site number 1, fig. 2). Gageheight record and discharge measurements were collected by the MVID from July 1913 to September 1915 and from April 1916 to September 1918. These records were furnished to the USGS; the monthly mean discharges were subsequently published in USGS Water Supply Paper 1049 (1947). The gage was reactivated in June 1928 by the University of Nevada Agricultural Experiment Station. Daily mean gage height and monthly runoff were furnished to the USGS from June 1928 to October 1931 and from April 1932 to July 1932. Monthly mean discharges for these periods also were published in Water Supply Paper 1049 (U.S. Geological Survey, 1947). The U.S. Bureau of Reclamation (Reclamation) reactivated the gage in October 1944 and constructed the 10-ft concrete Cipolletti weir (Appendix B, fig. B2). Reclamation collected continuous streamflow data until October 1948 when operation of the gage was turned over to the USGS. Daily mean discharges from 1944 to 1948 were computed by Reclamation and reviewed by the USGS. Daily mean discharges from 1944 to 1952 were subsequently published in Water Supply Paper 1243 (U.S. Geological Survey, 1954). Since 1952, the USGS has continued to operate and maintain the gage. Daily mean discharges for water years 1953 to 1960 were published annually in Water Supply Papers 1283 (1953), 1393 (1955), 1443 (1956), 1513 (1957), 1563 (1958), 1633 (1959), and 1713 (1960). For water years 1961 to 2004, the data were published in the USGS, Nevada District annual data report series (U.S. Geological Survey, Nevada District annual data reports, 1962-2004). A water year is the 12 month period from October 1 to September 30.

To analyze the gaging-station record as a means of characterizing spring discharges, a series of discharge measurements and estimates were made by the USGS at 40 sites in the Warm Springs area during September 10-12, 1963 (Eakin, 1964). As only a sketch map of these sites was available, a field reconnaissance was made during June 2004 to verify the location of each site and to obtain accurate coordinates. The coordinates, sketch map, and discharge and specific conductance data for these sites are included in Appendix D.

By the mid-1960s, the NPC withdrew ground water from wells in the northwest corner of the Warm Springs area as water supply for the Reid Gardner Generating Station about 3 mi downstream (fig. 1). In February 1966, NPC filed application with the Nevada State Engineer to pump additional water from these wells. In an agreement with the Muddy Valley Irrigation Company, NPC agreed to fund several "non-recording type weirs" on the major springs in the Warm Springs area. As part of the agreement, these hydraulic structures were to be under the jurisdiction of the State Engineer who would then measure the water levels on a periodic basis (Testolin and others, 1993). During August and September 1967, nine steel Parshall flumes were installed by the Desert Research Institute (DRI) under the direct supervision of the Nevada Division of Water Resources (NDWR). The nine flumes were installed at the following springs: Pipeline Jones, Flowing Well (Willow), Baldwin House Spring \#1 (South), Baldwin House \#2 (North), Baldwin Cuts, Baldwin Channel, Muddy (Big), Iverson, and Pederson. The locations, throat dimensions, and water-level data for eight of the nine flumes are included in Appendix B; waterlevel data were not available for the Flowing Well (Willow). Because flow rates were not included with the data provided by NDWR, discharges were computed for each water-level measurement using standard rating equations, from Leupold and Stevens (1987) for the reported size of each Parshall flume. Graphs and tables of the discharges for the period of record for each site are included in Appendix B. All the original nine flumes installed in 1967 have either been replaced or removed. The locations of the two Baldwin House Spring flumes near Cardy Lamb Springs and the Flowing Well (Willow) Flume could not be verified during this study; therefore, their exact locations are unknown.

Although not mentioned in Testolin and others (1993), NDWR reported an additional Parshall flume, Big Wash Flume, that was installed in October 1967 on the North Fork Muddy River about $500 \mathrm{ft}$ upstream of the confluence with South Fork Muddy River (fig. 2). Water-level readings from 1967 to 1984 for this site were provided by NDWR and are included in Appendix B, table B2. The flume washed out sometime after 1984 and currently is upside down on the south bank of the river (Appendix B, fig. B6). The flume dimensions, as reported by NDWR, were verified in the field, and discharges were computed for the periodic gageheight readings using the standard rating for a 3-ft Parshall flume (Leupold and Stevens, 1987). A graph and table of the computed discharges for Big Wash Flume are included in Appendix B (fig. B7, table B2).

Beginning October 1, 1977, records of flow for the Muddy River Power Diversion, about $100 \mathrm{ft}$ upstream of the USGS stream-gaging station at Warm Springs Road, Moapa (Appendix B, fig. B1) were provided by NPC to the USGS. Monthly mean discharges were published in the USGS Nevada District annual data reports for water years 1977 through 1985. Daily mean discharges were retrieved from the USGS National Water Information System (NWIS) database and are included in Appendix B (fig. B8, table B3). Annual mean daily discharge from the diversion for the period of record was $3.45 \mathrm{ft}^{3} / \mathrm{s}$.

In 1978, a new flume, reported by NDWR as the Garden Ditch Flume, was installed on the north spring tributary just inside the entrance gate to Apcar (Pipeline Jones) Springs 
(Appendix B, fig. B1). It is uncertain who installed the flume; however, field reconnaissance of the area in September 2004 indicated that the flume had been removed. The dimensions of the flume were obtained from a DRI report prepared for NPC as part of an evaluation of all flumes in the Warm Springs area (Wert and Pohlmann, 1992). Periodic water-level readings at this site through June 1992 also were provided by NDWR. Water levels, along with a graph and table of the computed discharges, are included in Appendix B (fig. B49, table B36).

In 1982, the USGS, in cooperation with local, State, and Federal agencies, began making periodic discharge measurements in the Warm Springs area as part of a long-term effort to characterize regional spring flow. By 1985, discharge measurements were being made at Warm Springs West (site 3, fig. 2), Muddy Springs at L.D.S. Farm (site 2, fig. 2), at Warm Springs East (site 9, fig. 2), and at Big Wash flume (fig. B5). The number of USGS periodic measurement sites continued to expand during the 1980s and 1990s and currently includes 11 partial-record stations (table 1). Graphs and tables of all discharge measurements made through September 2004 for all the sites are included in Appendix B.

In August 1985, the USGS, in cooperation with LVVWD and NDWR, installed continuous-stage recorders at the flumes at Warm Springs West and Muddy Springs at L.D.S Farm to document daily fluctuations in spring discharges. Daily mean discharges were computed for the spring flows at these gages and published in the USGS, Nevada District, annual data reports (1985-2004). Both stations are still operated and maintained by the USGS. Graphs and tables of daily mean discharges for the period of record for Warm Springs West and Muddy Springs at L.D.S Farm are included in Appendix B (fig. B42 and table B31, and fig. B46 and table B34, respectively).

In October 1986, the USGS, in cooperation with LVVWD and NDWR, installed an aluminum weir and continuous-stage recorder on the Pederson Springs pool (site 4, fig. 2). The purpose of this gage was to collect daily discharge data near the outlet of one of the major springs in the Moapa Valley National Wildlife Refuge. By early 2004, most of the palm trees surrounding the spring had been removed by the U.S. Fish and Wildlife Services (FWS), and in April 2004, a new weir was installed because water was leaking around the weir and the gage was not measuring flows accurately. Graphs and tables of daily mean discharges for the period of record are included in Appendix B (fig. B30, table B20).

By the early 1990s, only 5 of the original 10 flumes installed in 1967 were still being measured. Gage-height readings for Baldwin House \#1 and \#2 flumes stopped in June 1980, presumably because of construction of the L.D.S. pond at Cardy Lamb Springs (site 10, fig. 2). Readings at the Baldwin Cuts flume ended in August 1985 which was about 11 years after the MVWD began diverting flow from Baldwin Springs. Garden Ditch flume, mentioned in a report by DRI (Wert and Pohlmann, 1992), was reported to be in fair working condition in 1992; however, readings stopped after June 1992.
As conditions of the remaining flumes had significantly deteriorated, NPC contracted DRI in 1992 to evaluate the performance of each flume (Wert and Pohlmann, 1992). DRI recommended replacing the old steel flumes at Baldwin Springs Channel, Pipeline Jones, Pederson (Warm Springs West), Iverson, and Muddy (Big) Springs with new stainlesssteel flumes that would be more resistive to the corrosive springflows. The DRI report by Wert and Pohlmann (1992), also discussed an "L.D.S Pool flume" which was described as downstream of the pond at Cardy Lamb Spring: Replacement of this flume was not recommended by DRI because flow was controlled by the pond, which was being used as storage for irrigation.

During the summer of 1993, NDWR replaced the five remaining flumes and continued to make periodic water-level measurements at each site. These periodic measurements are included in the flume records provided by NDWR and are given in Appendix B (figs. B42, B46, B53, B63, B66 and tables B30, B33, B41, B49, B50).

In April 1997, Converse Consultants, on contract to NPC, began making quarterly field measurements of temperature and specific conductance at 18 spring and surface-water sites within the Warm Springs area. The spring and surface-water sampling is part of a comprehensive hydrologic-monitoring program that Converse Consultants manages in the Warm Springs area and vicinity. Converse Consultants submits an annual report to NPC summarizing all surface-water, groundwater, water-quality, and water-use data collected or compiled (Converse Consultants, 2004). The location of each spring sampling site, plus data graphs and tables, are included in Appendix B (figs. B9, B18 to B26, B32, B44, B48, B50, B51, $\mathrm{B} 54, \mathrm{~B} 55, \underline{\mathrm{B} 57}, \mathrm{~B} 61, \underline{\mathrm{B} 68}, \underline{\mathrm{B} 70}, \mathrm{~B} 71$ to $\mathrm{B} 74$ and tables B10 to $\underline{B} 17, \underline{B} 21, \underline{B} 32, \underline{B} 37, \underline{B} 38, \underline{B} 42, \underline{B} 48, \underline{B} 52$ to B55).

In December 1997, MVWD began collecting water samples from the pump houses at Baldwin and Apcar (Pipeline Jones) Springs. Samples are collected at these sites annually and are analyzed for major ions and selected dissolved constituents. Analyses of the water samples for 1997 through 2004 for the Baldwin and Apcar Springs are included in Appendix B (tables B39 and B43, respectively).

On June 1, 1998, FWS installed a staff gage and steel weir at the spring on the Plummer West tributary, one of the three tributaries of the Plummer Springs Group (Appendix B, fig. B9). This site, referred to as station M-16 by the USGS, has been measured by the USGS since 1987 . The staff gage was read several times a month by FWS from 1998 to 2002. Discharges were computed by applying the standard rating for a 90-degree v-notch weir (Rantz and others, 1982). Data collected at this site are given in Appendix B (tables B7 and B8). On October 26, 1998, FWS began making periodic discharge measurements in Plummer Main tributary (Appendix B, fig. B9). This site, also referred to as Warm Springs East, has been measured by the USGS since 1982. Periodic discharge measurements at this site were made by FWS using either a pygmy current meter or a Marsh- 
McBirney velocity meter. Several measurements were made each year until the site was discontinued on May 30, 2001. Graphs and tables of discharge data for the Warm Springs East site are included in Appendix B (fig. B10, tables B4 and B5).

On February 6 and 7, 2001, a series of discharge measurements were made within the Warm Springs area as part of a seepage study for the Muddy River. Discharge and water-quality data were collected by USGS, SNWA, FWS, and NDWR at 14 sites, including the 5 NDWR flumes and the 9 sites measured in September 1963 (Beck and Wilson, 2006). Location information and data collected at these sites are included in Appendix E.

A continuous-stage recorder was installed by the USGS, in cooperation with SNWA, at the Iverson flume on Refuge Stream on October 1, 2001 (fig. B65). At the time the gage was installed, flow was backed up at the flume because of palm trees and other debris blocking flow downstream. The stage-discharge relation for this station was developed and is maintained using current-meter measurements of discharge. A graph and tables of computed and daily mean discharges through September 2004 are included in Appendix B (fig. B66, tables B50 and B51)

By 2002, all the palm trees that surrounded the former recreational pool at Pederson East Spring in the Moapa Valley National Wildlife Refuge had been removed by FWS. On May 10, 2002, the USGS, in cooperation with SNWA and FWS, installed a recording gage with weir control. A graph and table of the daily mean discharges collected through September 2004 are included in Appendix B (fig. B27, table B18).

Water-quality samples were collected in 2004 by DRI at Pederson East Spring, M-13, Baldwin Springs, and Muddy Springs at L.D.S Farm. Field measurements of temperature, $\mathrm{pH}$, specific conductance, and dissolved oxygen were made and water samples were collected and analyzed for major ions and stable hydrogen and oxygen isotopes. Tables summarizing the field and laboratory results for each site are included in Appendix B (tables B19, B26, B35, and B44).

\section{U.S. Geological Survey Monitoring Stations}

Site identification numbers were assigned to each USGS monitoring station in this report, whether continuous or partial-record site. For all continuous-record and some partial-record sites, these numbers range from 8 to 10 digits and are designated in order of downstream direction along a main stream. For example, the complete 8-digit number for station 09416000 (Muddy River near Moapa) includes a 2-digit part number (09), plus the 6-digit downstream order number (416000). The part number refers to an area, the boundaries of which coincide with specified natural drainage boundaries. Records in this report are for sites in Part 09, the Colorado River Basin. When a station is added between two consecutively numbered stations, an additional digit is added to the upstream station number.
Most of the partial-record gaging stations in this report have site identification numbers based on the grid system of latitude and longitude. These numbers consist of 15 digits and provide a general geographic location and a unique number for each site. The first 6 digits denote the degrees, minutes, and seconds of latitude; the next 7 digits denote degrees, minutes, and seconds of longitude. The last two digits are sequential numbers for sites within a 1-second grid. For example, the site at Warm Springs East has a complete 15-digit number of 364236114424301 . This site is located at 36 degrees, 42 minutes, 36 seconds latitude and 114 degrees, 42 minutes, 43 seconds longitude. It is the first station recorded in that 1 -second grid. The description of geographic locations of a station may be refined, but the unique identification number remains unchanged.

\section{Continuous-Record Stream-Gaging Stations}

A continuous-record stream-gaging station is a site where data are collected with sufficient frequency to define daily mean values and variations within a day. Continuous-record gaging stations are equipped with instrumentation that records the gage height (stage) for the stream at selected frequencies, typically 15-minute intervals. These stage recordings are stored by a data logger and then later downloaded or transmitted into the USGS NWIS database. Discharge measurements are made at selected intervals, usually every 6 to 8 weeks. These data, together with supplemental information, are used to compute daily discharges (Rantz and others, 1982). The locations of the six continuous-record gaging stations currently operated within the Warm Springs area by the USGS, in cooperation with SNWA, are shown in figure 2. The sites also are listed in table 1 and include the following: Muddy River near Moapa (09416000), Muddy Springs at L.D.S. Farm near Moapa (09415900), Warm Springs West near Moapa (09415920), Pederson Spring near Moapa (09415910), Pederson East Springs near Moapa (09415908), and Warm Springs Confluence at Iverson Flume near Moapa (09415927). Site information, photographs, and graphs and tables for daily mean discharge for the period of record for these sites are included in Appendix B.

\section{Partial-Record Stream-Gaging Stations}

A partial-record stream-gaging station is a site where stage, discharge, or other hydrologic measurements are made one or more times during a year but at a frequency insufficient to develop a daily record. There is no instrumentation recording gage height at these sites. Measurements of gage height and corresponding discharge are done manually by field personnel. The USGS currently monitors 11 partialrecord gaging stations in the Warm Springs area. These sites typically are visited and measured every 6 months. Eight of the 11 stations are within two of the major spring 
groups, Pederson and Plummer. The locations of all partialrecord gaging stations are shown in figure 2 and given in table 1. Sites in the Pederson Spring Group include: Station 364235114425201 (M-11), Station 364237114425401 (M-12), Station 364236114425401 (M-13), Station 364235114425301 (M-19). Sites in the Plummer Spring Group include: Warm Springs East (364236114424301), Muddy River Springs 16 (364238114424201 or M-16), 364238114424401 (M-15 or Plummer Central), and Muddy River Springs 20 (364238114424301). Other partial-record sites include Muddy River Springs M-10 (364327114430801), Baldwin Springs near Moapa (09415875), and Apcar Stream at Pipeline Jones flume near Moapa (09415940). Site information, photographs, and graphs and tables of discharge measurements for the period of record for these sites are included in Appendix B.

\section{Summary}

The U.S. Geological Survey (USGS), in cooperation with Southern Nevada Water Authority and Nevada Division of Water Resources (NDWR), operates and maintains a surfacewater network of 6 continuous-record stream-gaging stations and 11 partial-record stations in the Warm Springs area near Moapa, Nevada. Permanent land-surface bench marks were installed in the Warm Springs area by the Las Vegas Valley Water District, the Southern Nevada Water Authority, and the USGS to determine water-surface elevations at these gagingstations. Vertical datum elevations and horizontal coordinates were established for all bench marks through a series of Differential Global Positioning System (DGPS) surveys. DGPS vertical datums were transferred to reference marks and points installed at each monitoring site using optical theodolite surveys. All surveys were completed by June 2004, and watersurface elevations were measured on August 17, 2004. Watersurface elevations ranged from 1,810.33 ft at Pederson Spring to $1,706.31 \mathrm{ft}$ at Muddy River near Moapa.

All USGS discharge and water-quality data published through September 30, 2004, for the Warm Springs area were compiled for this study. Additional discharge and waterquality data were provided by other agencies that manage, regulate, study, or use the water resources of the area. Periodic water-level readings for 10 flumes were provided by NDWR. U.S. Fish and Wildlife Service provided discharge data for springs within the Moapa Valley National Wildlife Refuge. Additional water-quality data were provided by the Moapa Valley Water District (MVWD), Desert Research Institute (DRI), and Converse Consultants.

Chronologies of water-resources development and hydrologic data collection are included in this report to illustrate the relation of the hydrologic monitoring network with historical and contemporary land- and water-use changes in the Warm Springs area. Prior to 1950, the Warm Springs area consisted of a few ranches that derived their water from individual springs or wells. From the 1950s to the late 1960s, most of the small ranches eventually merged into one working ranch with large land areas watered by an intricate network of irrigation ditches. Recreational facilities were established to take advantage of the warm spring waters for year-round aquatic and outdoor activities. The first exportation of water from springs in the study area was for supply to a nearby power plant and to growing communities to the south. As a result of these activities, flumes were installed near the major spring groups to monitor effects of water withdrawals and diversions.

Toward the late 1970s, environmental concerns resulted in the creation of the Moapa Valley National Wildlife Refuge that eventually terminated two of the three recreational developments. Additional hydrologic monitoring was started to characterize the water resources within the refuge for the protection and management of the Moapa dace. During the 1980s, additional ground-water and surface-water sources were tapped to meet the growing capacity of the powerplant. To provide better monitoring of the effects of water withdrawals, additional gages were installed and existing flumes were upgraded. In the 1990s, the wildlife refuge was expanded and additional monitoring sites were established.

In the past 4 years, two new recording gages were installed and major improvements were made to an existing site. With the completion of the water-surface surveys and the compilation of discharge and water quality data, this upgraded network will help identify potential effects on the water resources as a result of (1) changes in vegetation within the former agricultural lands, (2) changes within the Wildlife Refuge due to restoration activities, (3) continued withdrawal of ground water within the valley, and (4) potential withdrawals of ground water from adjacent basins.

\section{Acknowledgments}

In appreciation to those who submitted the materials used in this report, the authors thank Tim Mayer, U.S. Fish and Wildlife Service, for providing discharge data for Plummer West and Plummer Main; Desi Brantley, Nevada Division of Water Resources, for providing gage-height readings and other information for the flumes; Susan Rose, MVWD; Jim Thomas, Desert Research Institute; and Anna Draa and Jay Dixon, Converse Consultants, for providing water-quality data. The authors also thank Phil Swain, Moapa Band of Paiutes; Amy Sprunger-Allworth, U.S. Fish and Wildlife Service; Gary Holt, L.D.S. Recreational Area; Richard Willer, NPC; Van Robinson, MVWD; and Gary Scoppettone, USGS, for providing historical information. Special thanks go to Jim and Iris Haworth and Richard and Lorraine Pedersen for providing historical perspectives and photos, and to Shane Wade for his knowledge of the area and for his assistance on our many field trips. 


\section{References}

Baxter, Clint, and Haworth, Jim, 1996, Howard Hughes, his other empire and his man: New York, Vantage Press, Inc., 219 p.

Beck, D.A., and Wilson, J.W., 2006, Synoptic discharge, water-property, and p.H. measurements for Muddy River Spings Area and Muddy River, Nevada: U.S. Geological Survey Scientific Investigations Report 2006-5237.

Converse Consultants, 2004, Groundwater level monitoring program-2003 Annual Report: Moapa, Nevada, 26 p.

Eakin, T.E., 1964, Ground-water appraisal of Coyote Spring and Kane Spring Valleys and Muddy River Springs area, Lincoln and Clark Counties, Nevada: Nevada Department of Conservation and Natural Resources, Ground-Water Resources Reconnaissance Series, Report 25, 40 p.

Eakin, T.E., 1966, A regional interbasin groundwater system in the White River area, southeastern Nevada: Water Resources Research, v. 2, p 251-271.

Hafner, A.L., 1967, 100 years on the Muddy: Springville, Utah, Art City Publishing Company, 384 p.

Holt, R.L., History of the Paiute Indians of Utah: accessed July 22, 2004, at http://www.onlineutah.com/paiutehistory. shtml.

Kennedy, E.J., 1988, Levels at streamflow gaging stations: U.S. Geological Survey Open-File Report 88-710, 42 p.

Leupold and Stevens, 1987, Stevens Water Resources Data Book (4th ed.): Beverton, Oreg., Leupold and Stevens, $190 \mathrm{p}$.

Mozejko, Dr. Al, 1981, Environmental assessment-Proposed land acquisition for Moapa dace (Moapa coriacea), an endangered species, Clark County, Nevada (rev. ed.): Portland, Oregon, U.S. Department of Interior, U.S. Fish and Wildlife Service, $101 \mathrm{p}$.

Prudic, D.E., Harrill, J.R., and Burbey, T.J., 1995, Conceptual evaluation of regional ground-water flow in the carbonaterock province of the Great Basin, Nevada, Utah, and adjacent states: U.S. Geological Survey Professional Paper 1409-D, $102 \mathrm{p}$.

Rantz, S.E., and others, 1982, Measurement and computation of streamflow-Volume 1, measurement of stage and discharge; Volume 2, Computation of Discharge: U.S. Geological Survey Water-Supply Paper 2175, 631 p.

Scoppettone, G.G., Burge, H.L., Tuttle, P.L., Parker, M., and Parker, N.K., 1987, Life history and status of the Moapa dace (Moapa coriacea): Seattle, Washington, U.S. Fish and Wildlife Service, National Fisheries Research Center, 77 p.
Scoppettone, G.G., Burge, H.L., and Tuttle, P.L., 1992, Life history, abundance, and distribution of Moapa dace (Moapa Coriacea), Great Basin Naturalist, v. 52, no. 3, p. 216-225.

Southern Nevada Water Authority, 2003, Survey of wells and stream gages in the Black Mountains area, California Wash Basin, Coyote Spring Valley, Garnet Valley, Hidden Valley and the Muddy River Springs Area, Nevada: Acheampong, S., Donovan, D., and Wallen, M., Project Team, May 2003, $13 \mathrm{p}$.

Testolin, W., Owsley, K., Coache, B., and King, J., 1993, Upper Muddy River flume replacement: State of Nevada Department of Conservation and Natural Resources Division of Water Resources, unpaginated.

U.S. Fish and Wildlife Service, 1991, A plan for the futureMoapa Valley National Wildlife Refuge, Nevada: U.S. Department of Interior, U.S. Fish and Wildlife Service, 8 p.

U.S. Fish and Wildlife Service, 1995, Recovery plan for the rare aquatic species of the Muddy River ecosystem, First Revision (Original Approved: February 14, 1983): U.S. Department of Interior, U.S. Fish and Wildlife Service, Portland, Oregon, 60 p.

U.S. Geological Survey, 1947, Summary of records of surface waters at stations on tributaries in lower Colorado River Basin 1888-1938: U.S. Geological Survey Water-Supply Paper 1049, p. 147-149.

U.S. Geological Survey, 1952-1961, Surface water supply of the United States. Annual reports as follows: 1952, Water Supply Paper 1243; 1953, Water Supply Paper 1283; 1955, Water Supply Paper 1393; 1956, Water Supply Paper 1443; 1957, Water Supply Paper 1513; 1958, Water Supply Paper 1563; 1959, Water Supply Paper 1633; 1960, Water Supply Paper 1713.

U.S. Geological Survey, 1954, Compilation of records of surface waters of the United States through September 1950, Part 9. Colorado River Basin: U.S. Geological Survey Water-Supply Paper 1313, p. 566-567.

U.S. Geological Survey, 1963, Surface water records of Nevada, 1963: U.S. Geological Survey Water-Data Report, $128 \mathrm{p}$.

U.S. Geological Survey, 1962-2004, Water resources data for Nevada, water years 1961-2004-volume 1; U.S. Geological Survey Water-Data Reports NV-61-1 to NV-04-1 (published annually).

U.S. Geological Survey, 2005, National Water Information System (NWIS) database, accessed 2005 at http://waterdata. usgs.gov/nwis.

Wert, B.L., and Pohlmann, K.F., 1992, Upper Muddy stream gaging program: Desert Research Institute, 8 p. 


\section{Appendix A. History of Water-Resources Development within the Warm Springs Area Near Moapa, Nevada}


This page left intentionally blank. 


\section{History of Water Resources Development}

The Warm Springs area has a rich history of farming, ranching, and recreation. The first known dwellers within the area were the Anasazi and the Southern Paiute Indians (Baxter and Haworth, 1996). Little is known about the Anasazi in southern Nevada. By the early 1800s, the Paiutes had sizable populations along the Muddy and Virgin Rivers (Holt, Ronald, accessed July 22, 2004 http://www.onlineutah. com/paiutehistory.shtml). Although most of these riverine and desert groups were primarily foragers and hunters, the Paiutes were known to also have irrigated crops, such as corn, squash, melons, and wheat, along the banks of the Muddy River (Mozejko, 1981). In addition to using the river as a source of irrigation and drinking supply, the Paiutes also used it for ceremonial rites, which are still practiced today within the Moapa Paiute Indian Reservation (Phil Swain, Moapa Band of Paiutes, oral commun., 2004).

From the 1870 s to the early 1880 s, Warm Springs was cohabited by Indians, outlaws, and prospectors. The first known ranch in the Warm Springs area was started in 1871 with several cattle and horses rustled by a fugitive bank robber from Texas. He built a rock house just north of the current Church of the Latter Day Saints (L.D.S.) Recreation Area (Baxter and Haworth, 1996). He called the ranch Stone Cabin Springs and worked it until his death in 1882.

The first Mormon settlers arrived in the Warm Springs area in 1889 and cleared and irrigated about 30 acres to grow alfalfa and cotton. Although several other ranches subsequently sprang up in the area, the longest worked ranch was the Home Ranch, which began about 1910. It was located north of Warm Springs Road, across from the Pederson Spring area. From 1910 to 1950, the Home Ranch changed ownership frequently but continued to be used primarily for farming and ranching. The largest parcel of land irrigated during this period was about 60 acres (Baxter and Haworth, 1996). By the 1940s, several of the larger springs in the area had gained popularity with locals and visitors for camping, swimming, and bathing (Jim Haworth, local resident, oral commun., 2004).

In 1950, Francis Taylor acquired the Home Ranch and changed the name to Warm Springs Ranch. Taylor eventually expanded the size of the ranch to about 1,200 acres, which was used, in part, to experiment with different pasture grasses and to breed cattle suitable for the desert environment (Baxter and Haworth, 1996). A large mansion that still exists and bears his name (fig. A1) was built adjacent to a large spring-fed pool (Muddy Springs) that is the source of flow discharging from the current L.D.S. Recreation Area. During the 1950s and early 1960s, large amounts of water were diverted from the springs when a network of approximately 6.5 miles of irrigation ditches, mostly concrete (fig. A2), were installed throughout the valley (Jim Haworth, local resident, oral commun., 2004). Only a few of these irrigation ditches are in use today as most have been abandoned or are unusable (fig. A2).
At the same time that the Warm Springs Ranch was expanding under Taylor's proprietorship, the 1950s ushered in two private recreational developments. The first was called the 7-12 Warm Springs Resort, which was located in the area currently known as the Pederson Springs area; it consisted of trailer parking, two swimming pools, a snack bar, and residential housing. The small pool (fig. A3) was filled directly by discharge from a spring below the pool, and the larger pool (fig. A4) was filled by diverting discharge from a spring. The second development became known as the Desert Oasis Warm Springs Resort, which encompassed most of the area currently called the Plummer Springs area but also included the former pool which is now known as Pederson East Spring (fig. A5). By the 1990s, the Desert Oasis Warm Springs Resort had developed into a private time-share/spa that ultimately included trailer parking, a spa, a swimming pool, ponds, a 5,000- $\mathrm{ft}^{2}$ mansion, and a water slide (figs. A6, $\underline{\mathrm{A} 7}$, and $\underline{\mathrm{A} 8}$ ).

In 1954, the Moapa Valley Water Company and the Overton Water District entered into a joint agreement to pump water from the Warm Springs area to residential, business, and dairy establishments to the south (Hafner, 1967). A small spring on a hillside on Francis Taylor's ranch was selected for a pump house and developed to create a discharge of about $2 \mathrm{ft}^{3} / \mathrm{s}$. In 1960, the pump house was installed on what is now called the Apcar (Pipeline Jones) Springs (fig. A9). Water $\left(1 \mathrm{ft}^{3} / \mathrm{s}\right)$ and land (1 acre) at the spring were donated to the Moapa Valley Water Company by Francis Taylor (Baxter and Haworth, 1996). Frederick Apcar subsequently purchased approximately 45 acres of land surrounding the spring and used the area primarily for his own private recreation. Apcar enlarged and concreted one of the springs and constructed a large swimming pool (fig. A9; Baxter and Haworth, 1996). A new pump house was constructed at Apcar Springs during the summer of 2004 by the Moapa Valley Water District (fig. A9).

In the mid-1960s, a coal-fired powerplant (Reid Gardner Generating Station) was constructed along the east bank of the Muddy River about 3 mi southeast of the Warm Springs area (fig. 1). Water required for plant operations initially was obtained from the Muddy River near the plant and from several wells owned by Clarvid Lewis located in the northwest corner of Warm Springs area (Richard Willer, Nevada Power Company, oral commun., 2004). By the early 1970s, the NPC constructed a diversion and pumping station along the north bank of the Muddy River about $100 \mathrm{ft}$ upstream of the USGS stream-gaging station at Warm Springs Road (fig. A10). Water is pumped directly from the river and transmitted by pipeline to the powerplant.

In 1968, shortly after the death of Francis Taylor, Howard Hughes, having seen the Warm Springs area during a test flight, purchased the entire Warm Springs Ranch. Although Hughes owned the Ranch for nearly 8 years, he reportedly never set foot on it (Baxter and Haworth, 1996). By the 
early to mid-1970s, water diverted for irrigation for ranch operations reached its maximum (Jim Haworth, local resident, oral commun., 2004). Water demand, however, continued to grow in the rest of Moapa Valley, and in 1974 the MVWD installed a pump house at Baldwin Springs (fig. A11). This pump house is still operating; however, the amount of water withdrawn, 6.5 acre-ft during 2003 (Converse Consultants, 2004), is significantly less than the amount pumped from Apcar Springs.

In 1978, 2 years after the death of Howard Hughes, the Warm Springs Ranch was purchased by the L.D.S. Church. After a couple of years, the cattle operation started to decline, and the church planted fruit and nut trees, hoping to develop the ranch as a welfare farm (Gary Holt, L.D.S. Recreation Area, oral commun., 2004). The experimental welfare farm was unsuccessful, and by the mid-1980s the Church had leased most of its water rights to NPC and sold off all but about 73 acres of the Ranch. The remaining church property, which kept the name of the Warm Springs Ranch (fig. A12) was subsequently developed into a recreational center for L.D.S. Stakes in southern Nevada. The area is now called the L.D.S. Recreational Area and includes a large swimming pool (fig. A12), campgrounds, and the renovated Francis Taylor mansion (fig. A1). The mansion survived a fire in 1987 that destroyed many of the old Warm Springs Ranch homes, barns, and corrals. The spring-fed pond is still used for swimming, and the large swimming pool is periodically filled with water from the spring-fed pond. The L.D.S. Recreation Area hosts numerous group outings and uses ground water pumped from a private well to support on-site residential and campground facilities.

In 1979, approximately 90 acres of land that included most of the 7-12 Warm Springs Resort and a small part of the Desert Oasis Warm Springs Resort was deemed by the Federal government as habitat for the endangered Moapa dace (Moapa coriacea). The property was purchased by the government and was designated as the Moapa Valley National Wildlife Refuge. The U.S. Fish and Wildlife Service (FWS) assumed custody of the refuge and began a long-term restoration program.

Development of another recreational area on L.D.S. church property was attempted in the early 1980s at the northwest end of the valley. Although the development reportedly was built by Lee Earl (Richard Pedersen, local resident, oral commun., 2004), the area has been called Cardy Lamb (Scoppettone and others, 1987). A large concrete pond and a bathhouse were built about $400 \mathrm{ft}$ east of Warm Springs
Road (fig. A13). The pond was built over one of the springs that had previously supplied irrigation water through the original concrete-ditch network to fields east of the area. The facility never materialized and the property eventually was sold (Richard Pedersen, oral commun., 2004). Water from the pond is used by the current owner to irrigate several nearby fields for livestock grazing. An underground drainage pipe connects the pond to the irrigation ditches.

In the early 1980s, NPC significantly increased the capacity of the Reid Gardner Generating Station. Although additional water was available from their Meadow Valley wells, the quality of the water was poor; consequently the company began purchasing water rights from the L.D.S. Church and other private owners in the Warm Springs area (Richard Willer, Nevada Power Company, oral commun., 2004). Currently, NPC pumps water from about 12 wells and 1 surface-water diversion from the Muddy River near Moapa (another intake pump was installed in 1999) in the Warm Springs area.

By 1986, most of the existing 7-12 Warm Springs Resort recreational facilities within the initial refuge boundary had been removed. These included the trailer hookups, swimming pools, and snackbar. The current conditions of the areas where the two swimming pools had been located are shown in figures A3 and A4. The Desert Oasis Warm Springs Resort continued to operate until a fire swept through the area in 1994. After the fire, the resort essentially remained unused until 1997 when the property was purchased by Del Webb and turned over to the FWS to be incorporated as part of the Moapa Valley National Wildlife Refuge (Amy SprungerAllworth, U.S. Fish and Wildlife Service, oral commun., 2004).

In 2001, the Federal government purchased the 45 acres adjacent to Apcar Spring and incorporated that property as part of the wildlife refuge. By spring 2002, the FWS had removed the former recreational pool at Pederson East Spring and many of the palm trees within the Pederson Spring Group (fig. A5) and had began restoration projects in the Plummer and Apcar Spring areas.

Farming and ranching continues today within the Warm Springs area, but land usage has dropped significantly since its peak in the mid-1970s. The set of aerial photographs in figure A14 depict the difference in the amount of acreage irrigated during 1976 and 2003. Estimated acreage irrigated in 1976 was about 600 acres compared with about 100 acres in 2003. 


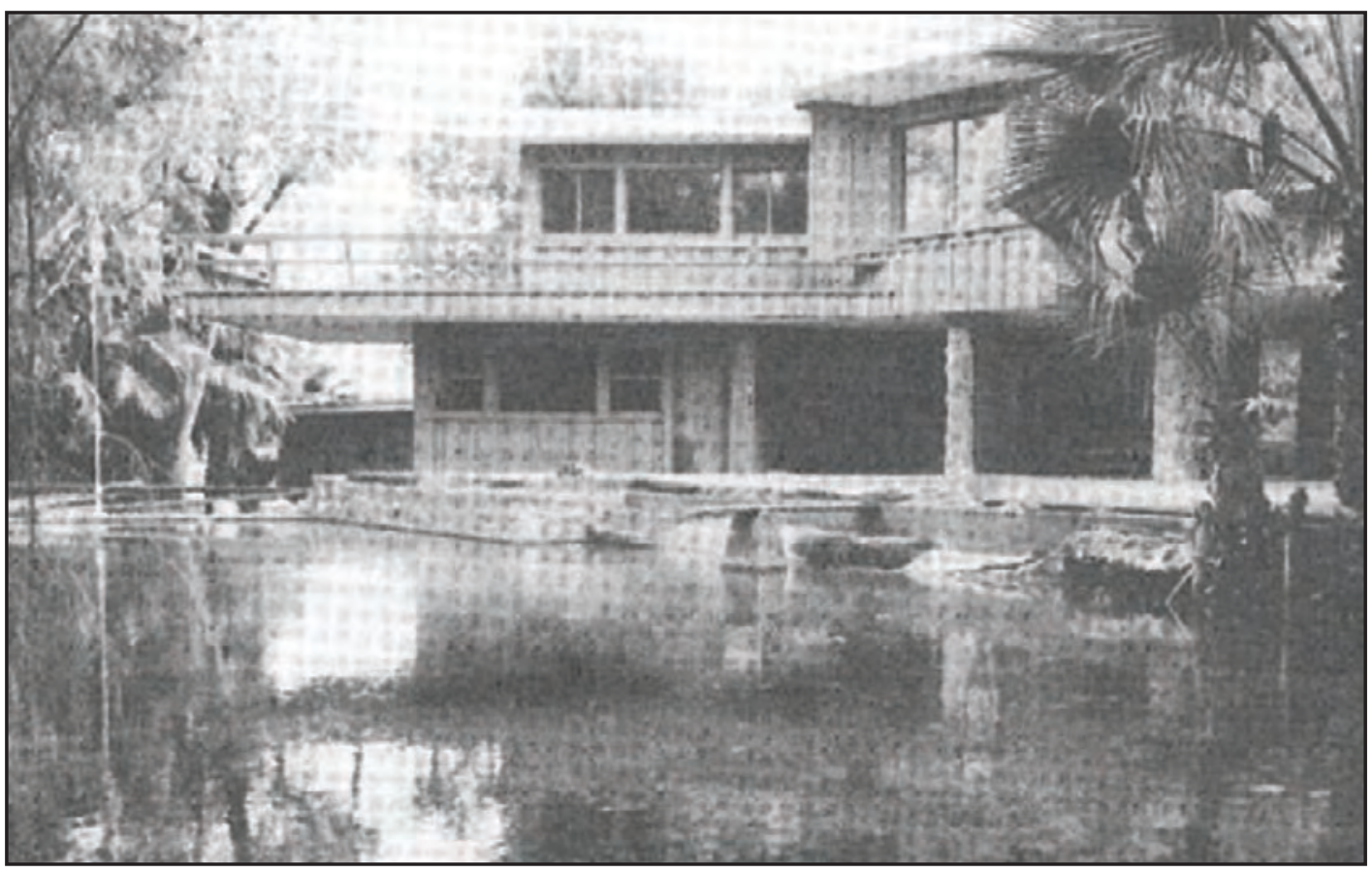

A. View of the mansion during the mid-1970s. Photograph from Baxter (1996).

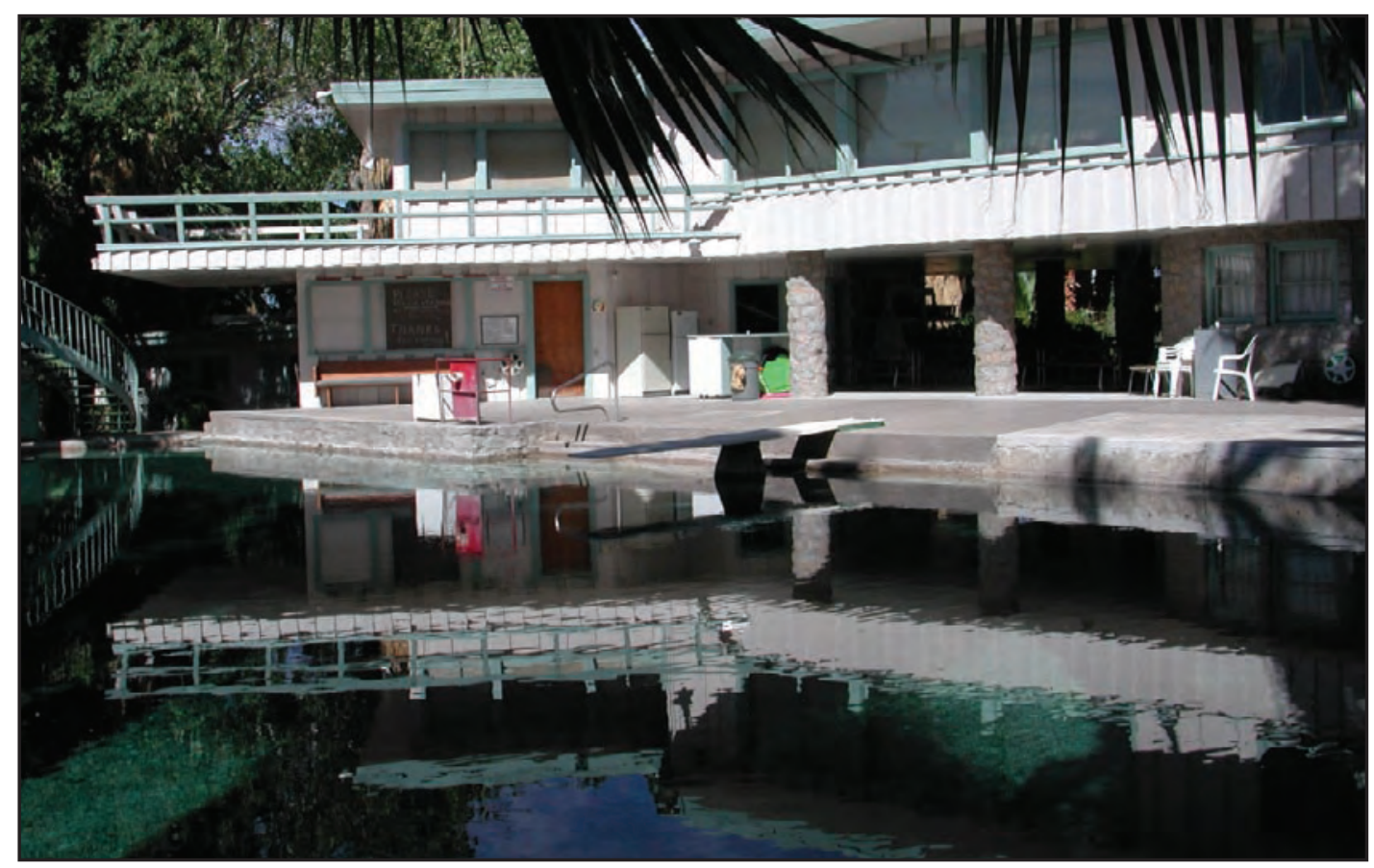

B. View of the mansion in July 2004. Photographed by D. Beck.

Figure A1. Francis Taylor mansion, built in the 1950s in the Warm Springs area near Moapa, Nevada. 


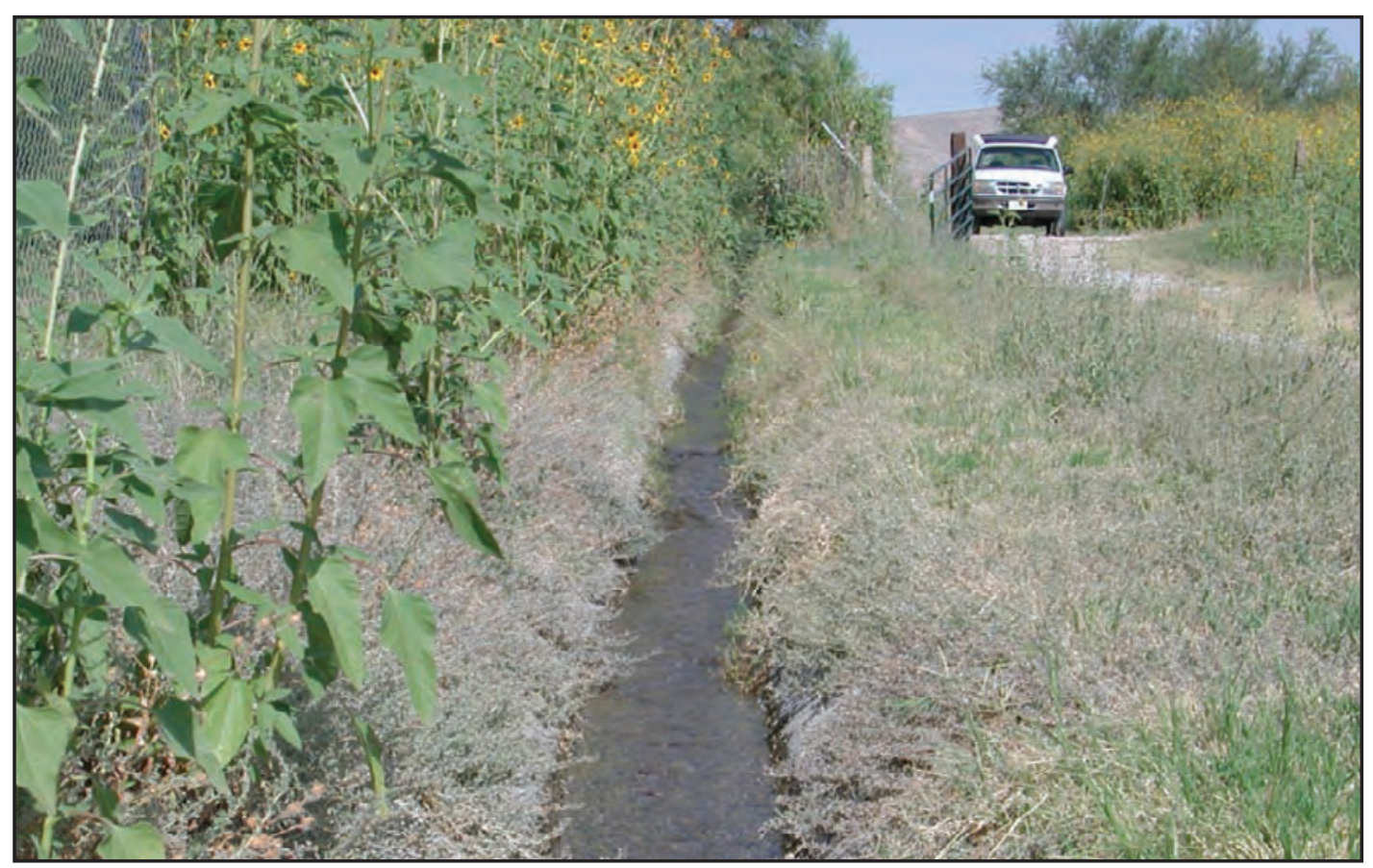

A. Concrete irrigation ditch east of Cardy Lamb Swimming Pond.

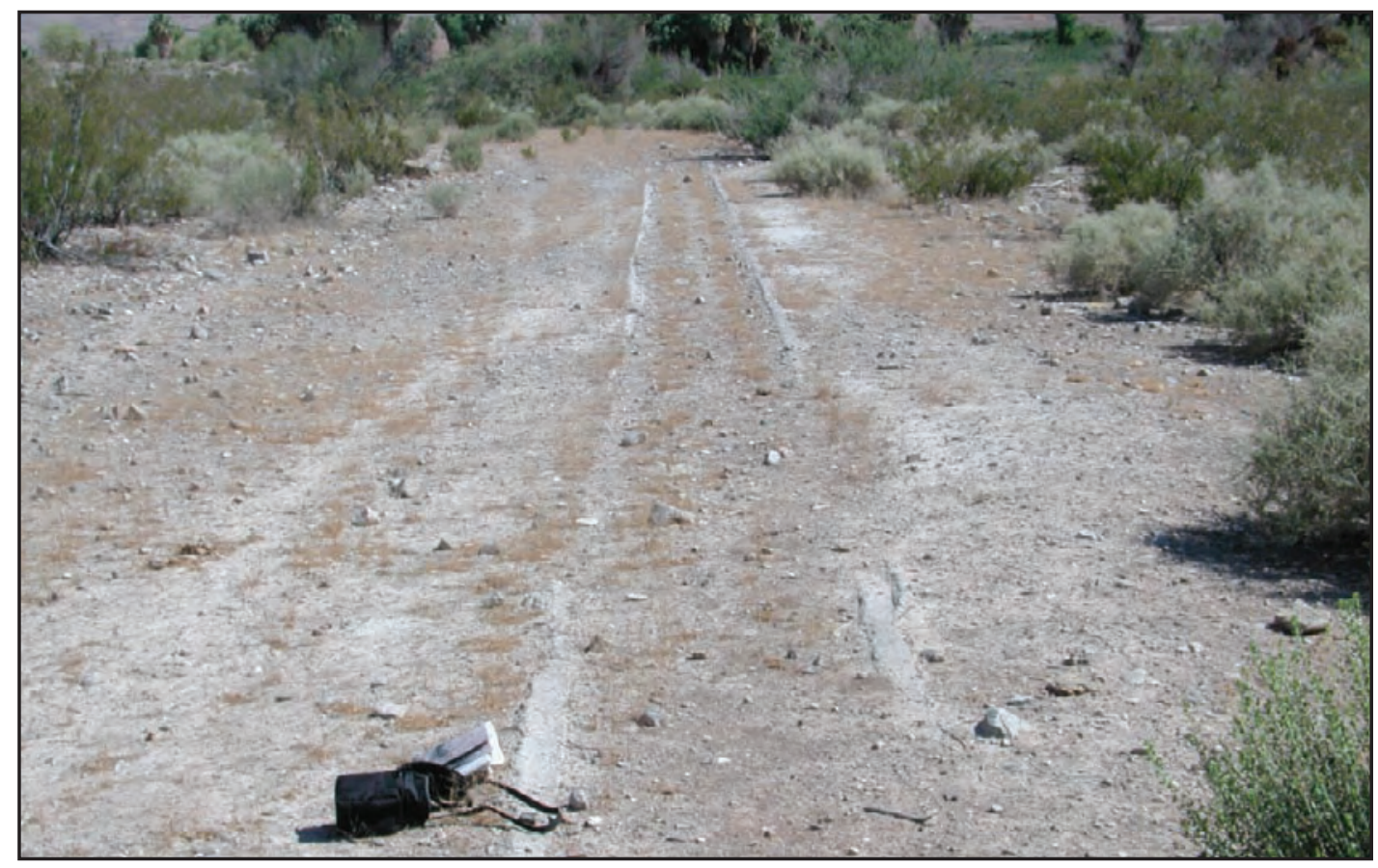

B. Former concrete irrigation ditch south of Cardy Lamb Swimming Pond that has been completely filled in with dirt.

Figure A2. Concrete irrigation ditches near Cardy Lamb Swimming Pond in the Warm Springs area near Moapa, Nevada. Both views photographed in June 2004 by D. Beck. 


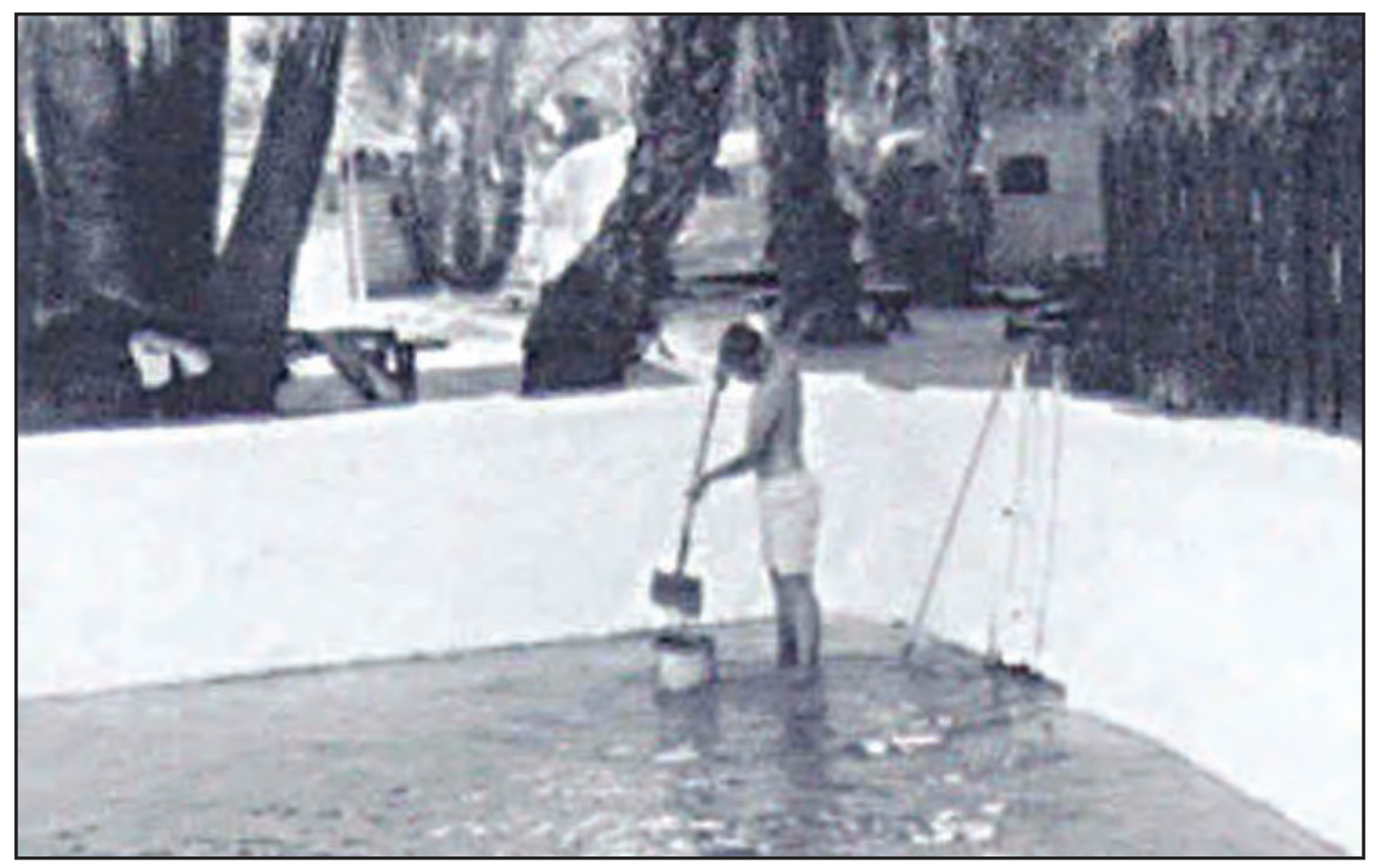

A. Former 7-12 Warm Springs Resort small swimming pool during the 1950s. Photograph courtesy of R. \& L. Pederson.

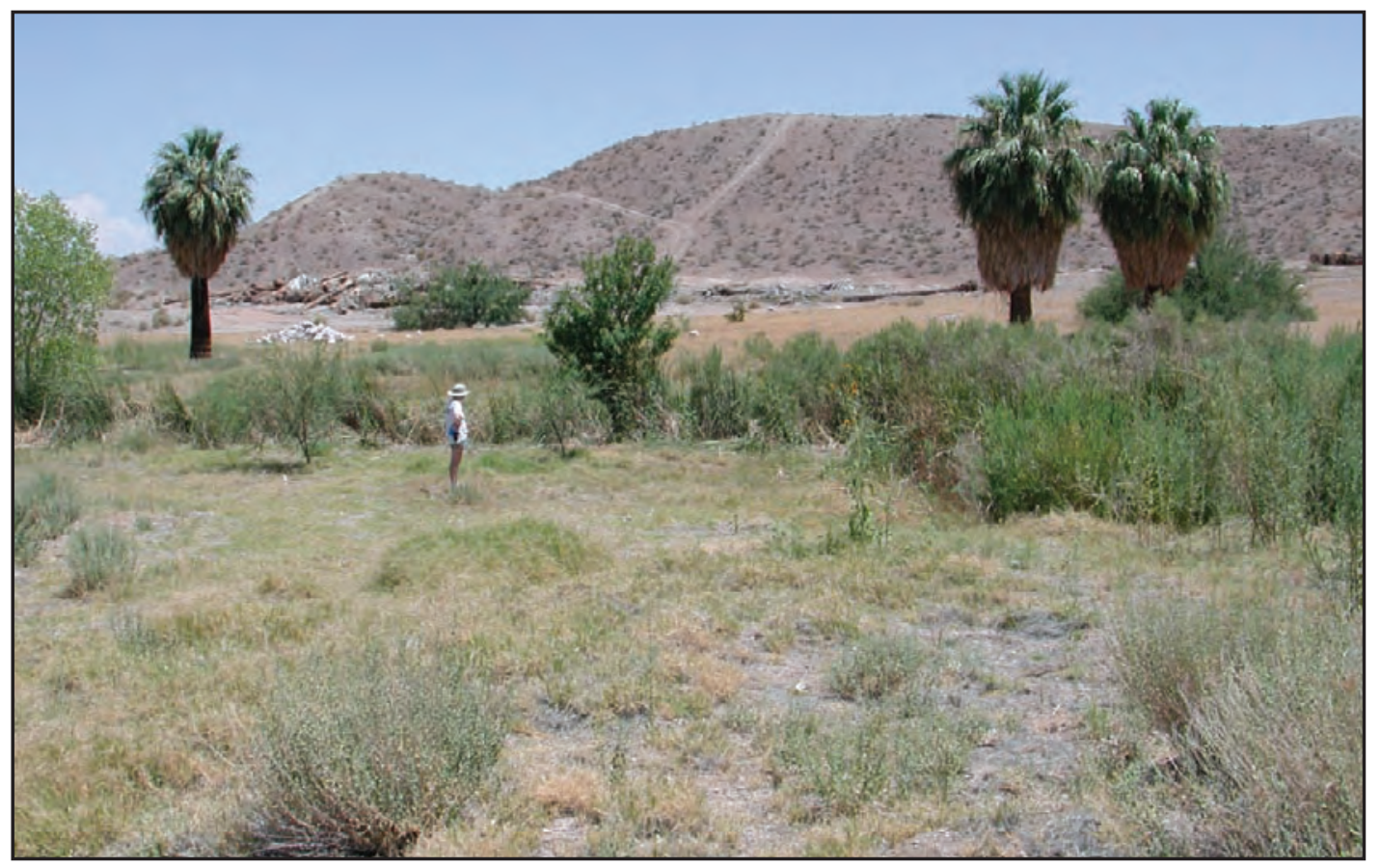

B. Same area after small swimming pool, trailer hookups, and palm trees were removed by the U.S. Fish and Wildlife Service. Photographed in June 2004 by D. Beck.

Figure A3. Former Warm Springs Resort small swimming pool, Warm Springs area near Moapa, Nevada. 


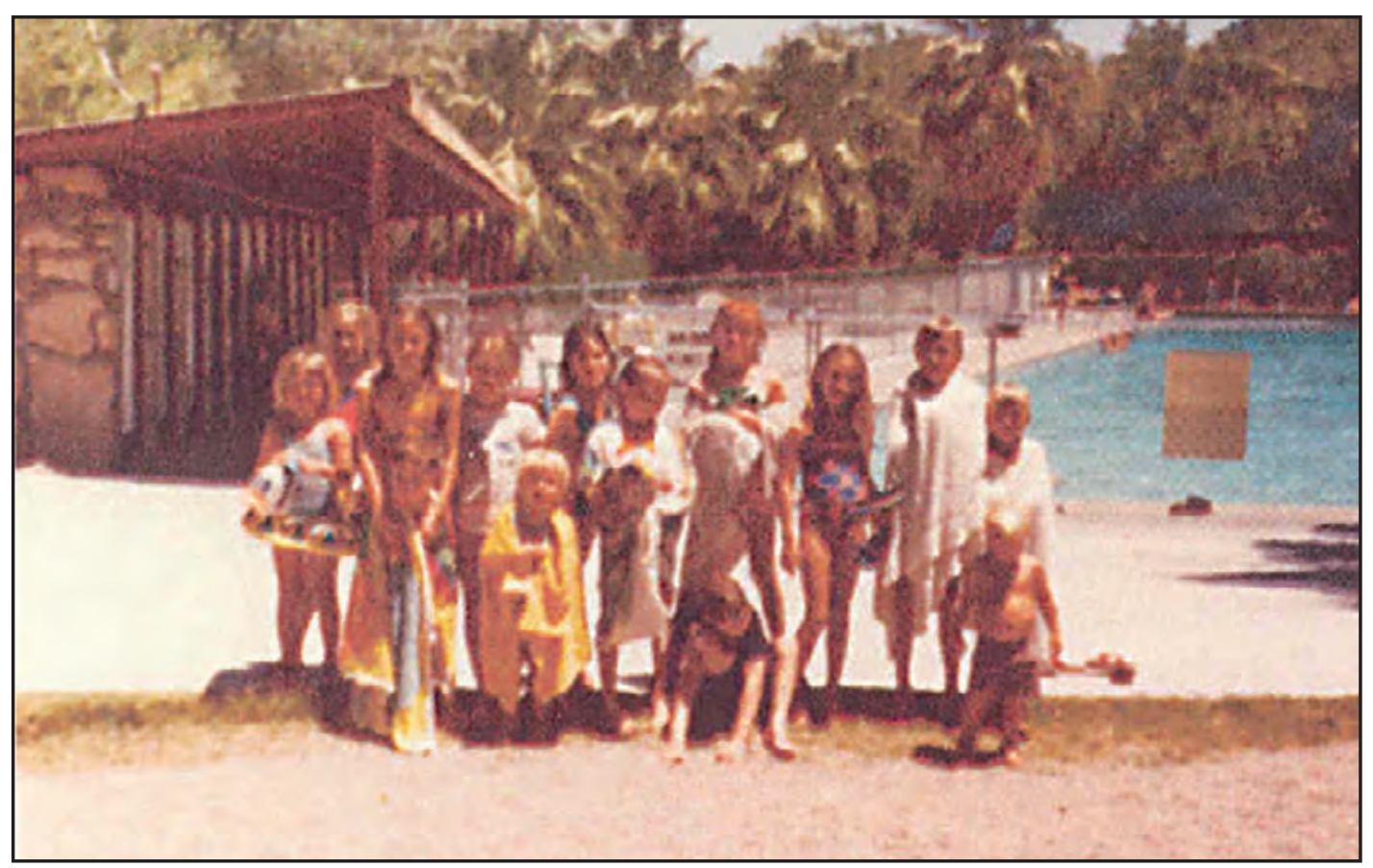

A. Former 7-12 Warm Springs Resort large swimming pool during the 1960s. Photograph courtesy of R.\& L. Pederson.

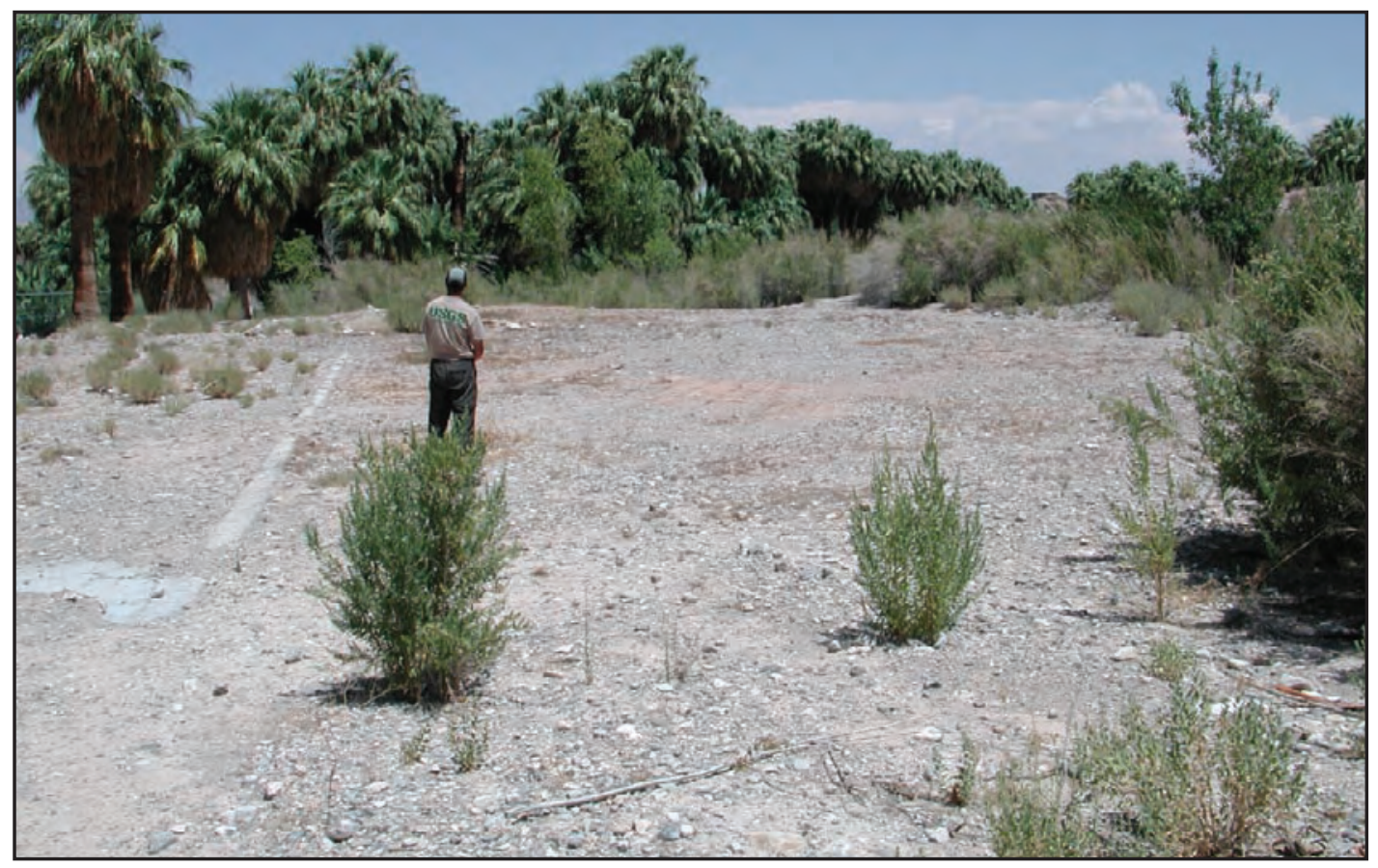

B. Same area after large swimming pool, bathhouse, and snackbar were removed by the U.S. Fish and Wildlife Service. Photographed in June 2004 by D. Beck.

Figure A4. Former Warm Springs Resort large swimming pool, Warm Springs area near Moapa, Nevada. 


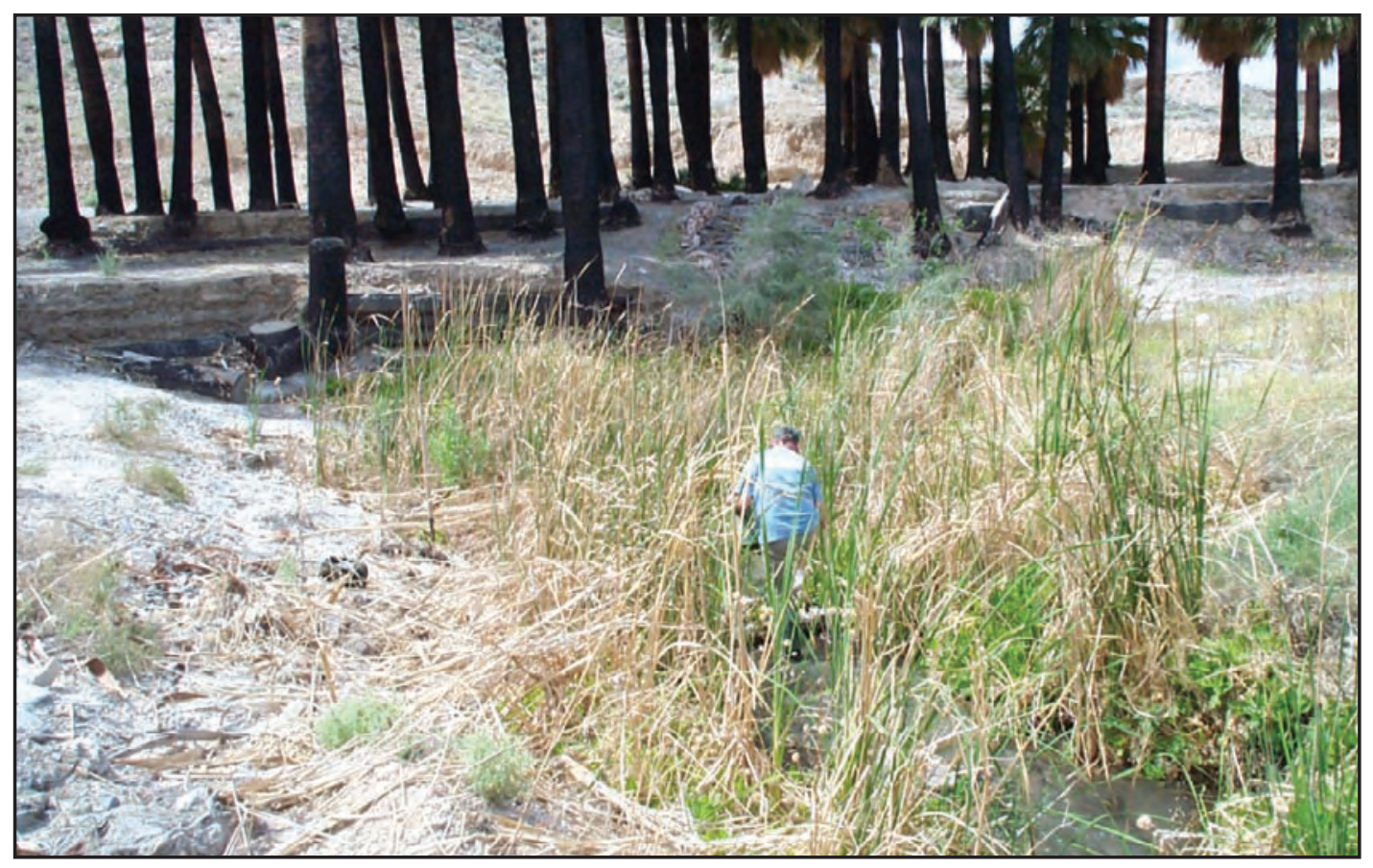

A. View in April 2000 of the spring and site of the former recreational pool.

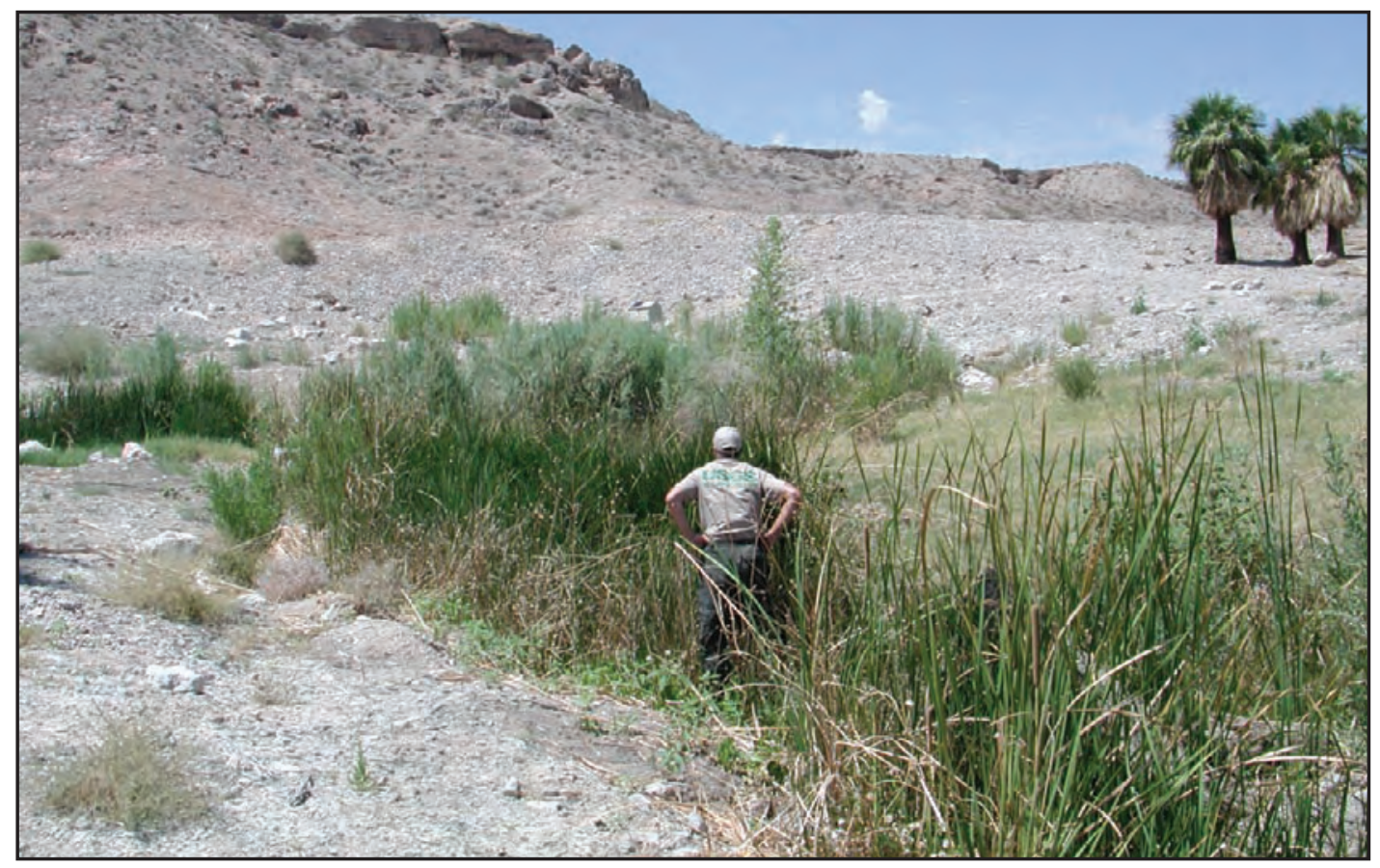

B. Same view in July 2004 after the pool structure and palm trees had been removed. Photograph by D. Beck.

Figure A5. Pederson East Spring in the Moapa Valley National Wildlife Refuge near Moapa, Nevada. 


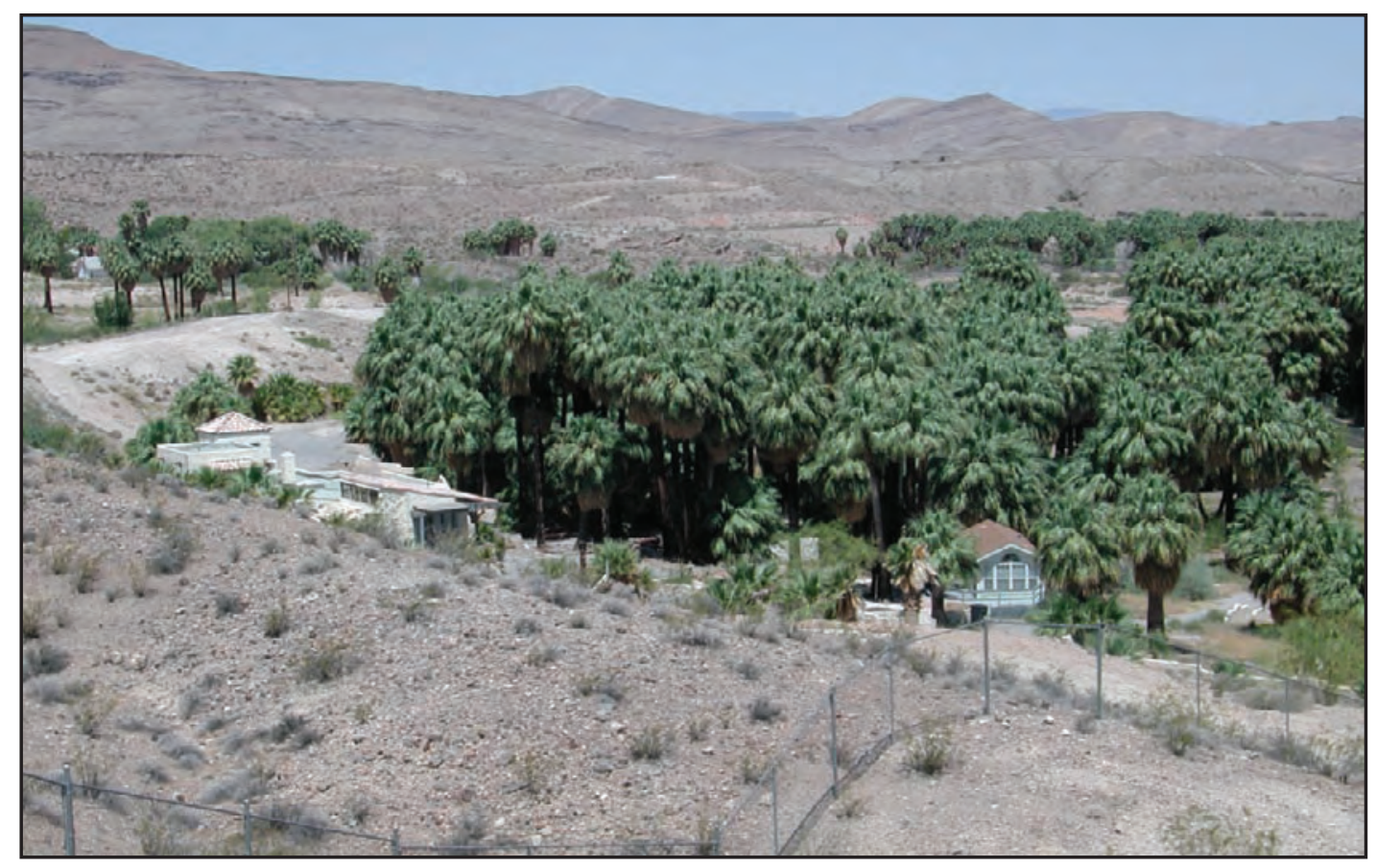

A. View of the mansion and spring area.

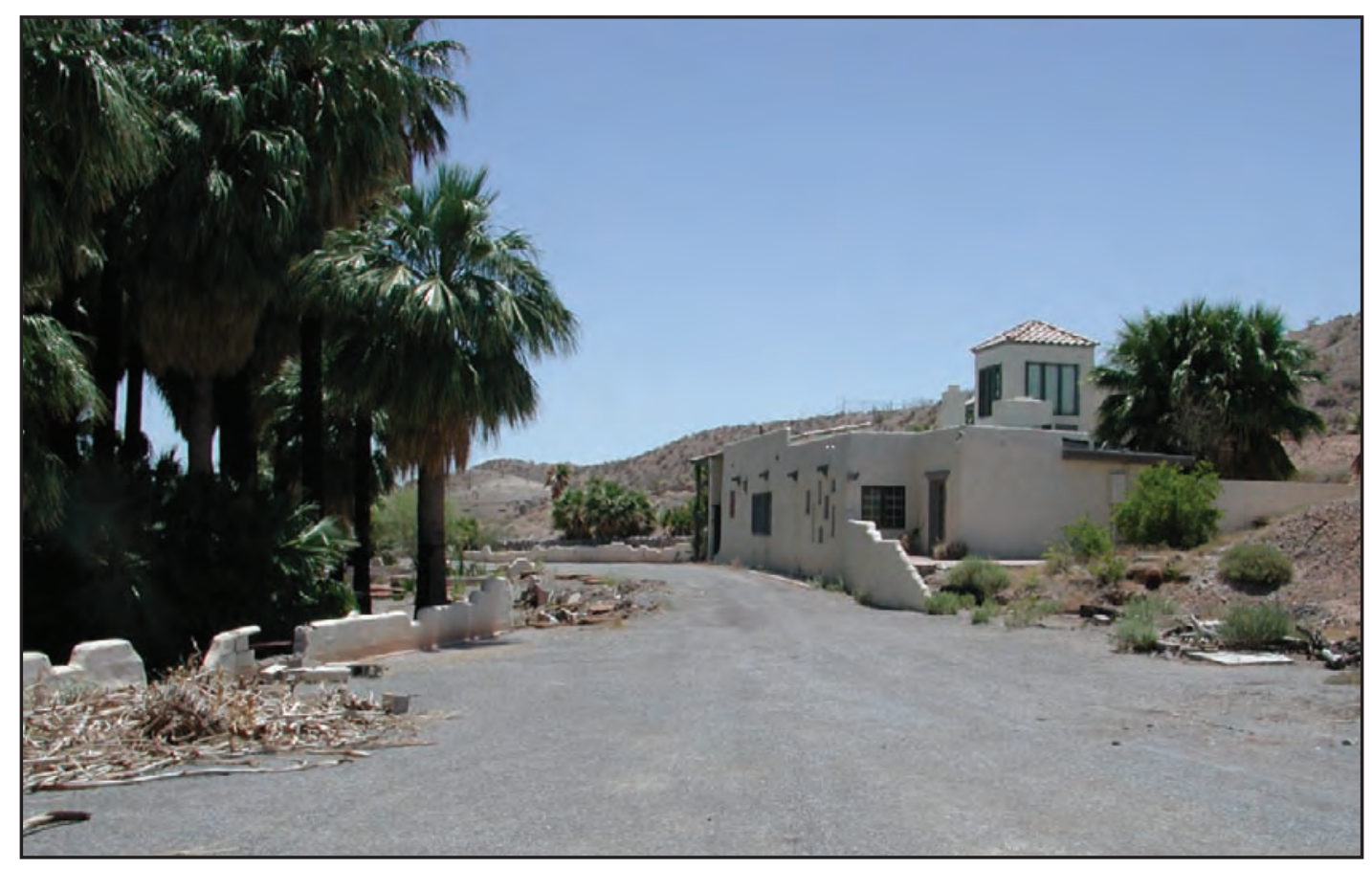

\section{B. View of the mansion and parking area.}

Figure A6. Former Desert Oasis Warm Springs Resort in the Warm Springs area near Moapa, Nevada. Both views photographed in July 2004 by D. Beck. 


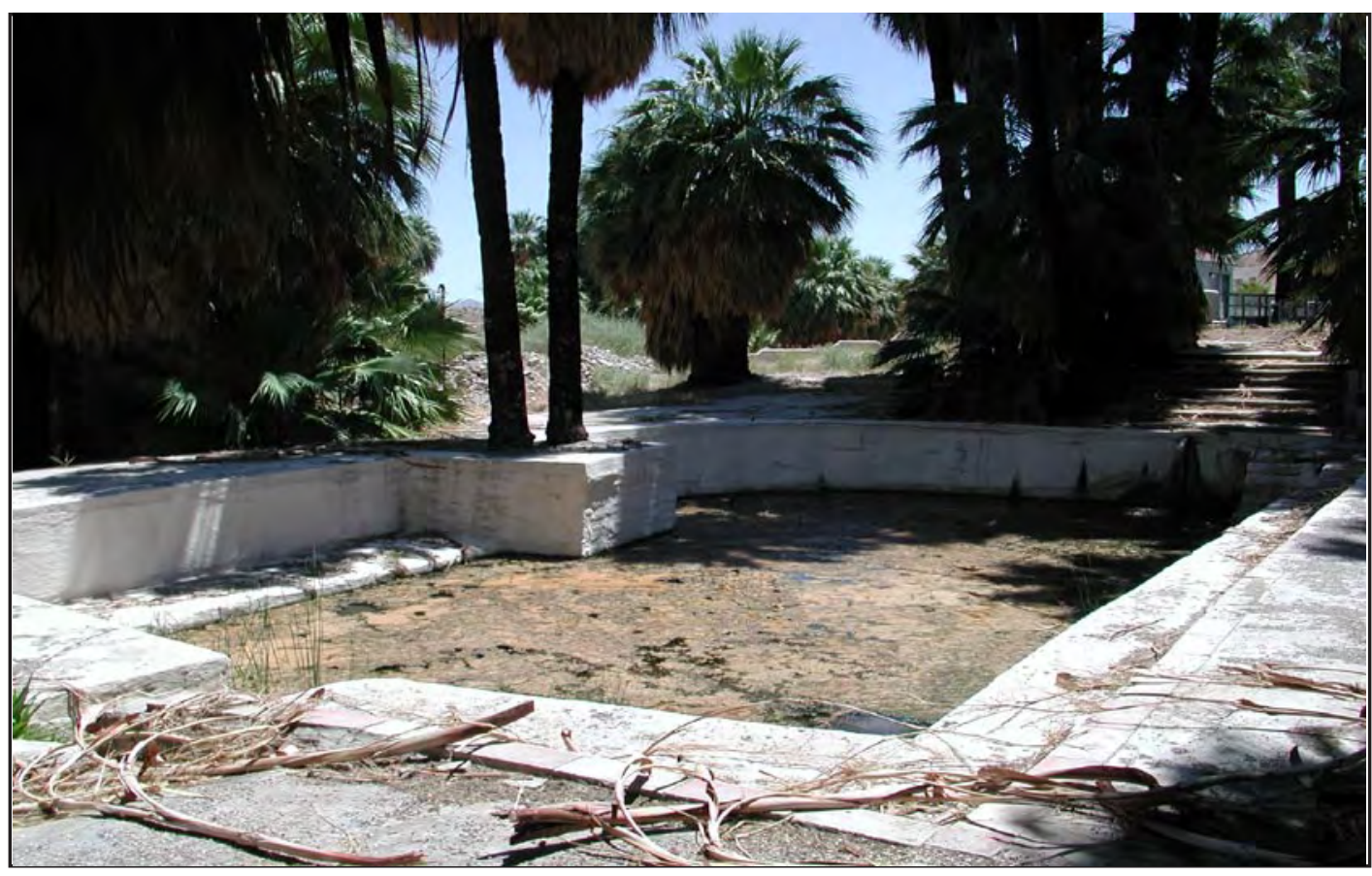

\section{A. Spring-fed swimming pool.}

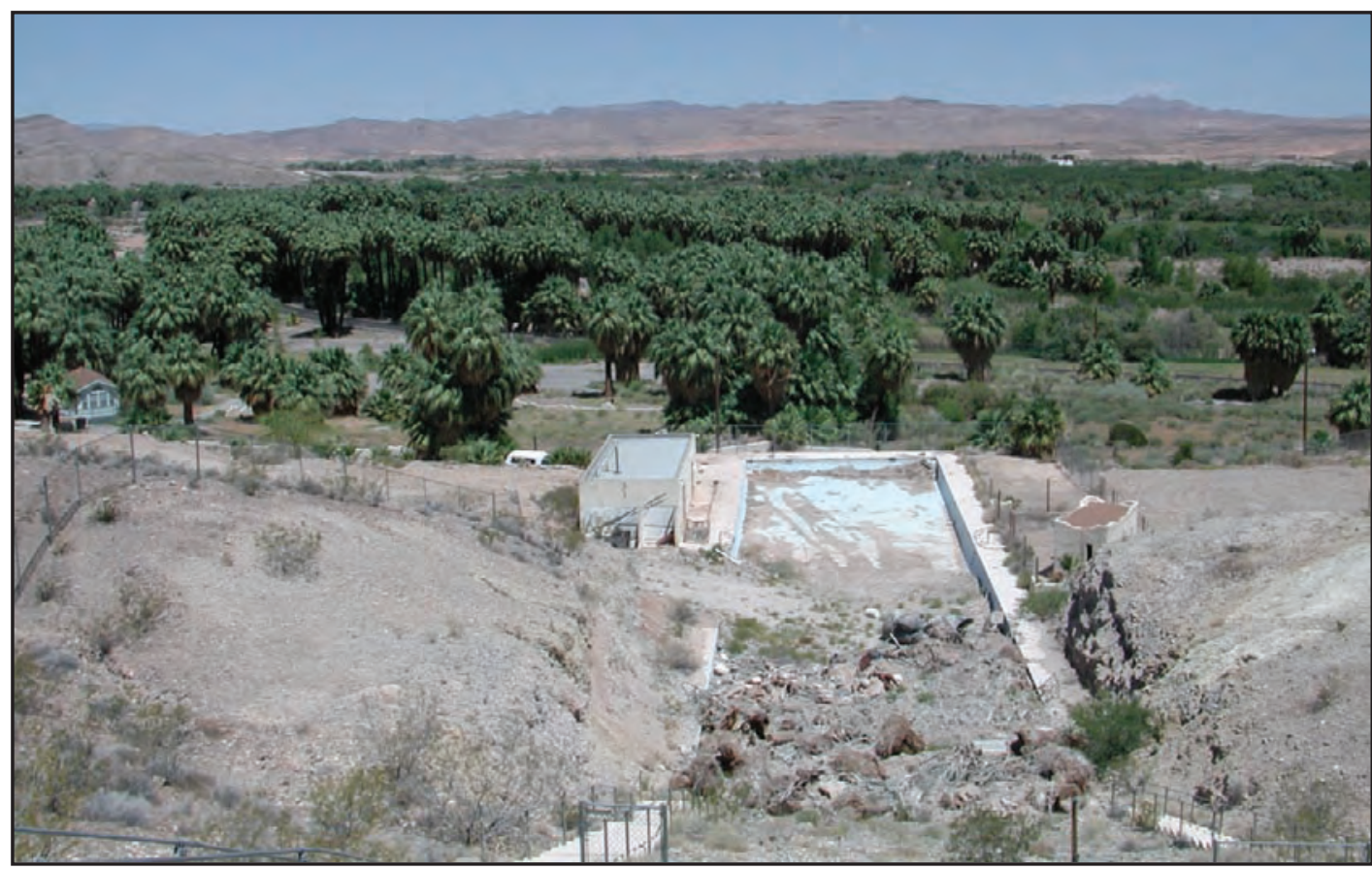

\section{B. Remains of a water slide and pool.}

Figure A7. Recreational facilities of the former Desert Oasis Warm Springs Resort in the Warm Springs area near Moapa, Nevada. Both views photographed in July 2004 by D. Beck. 


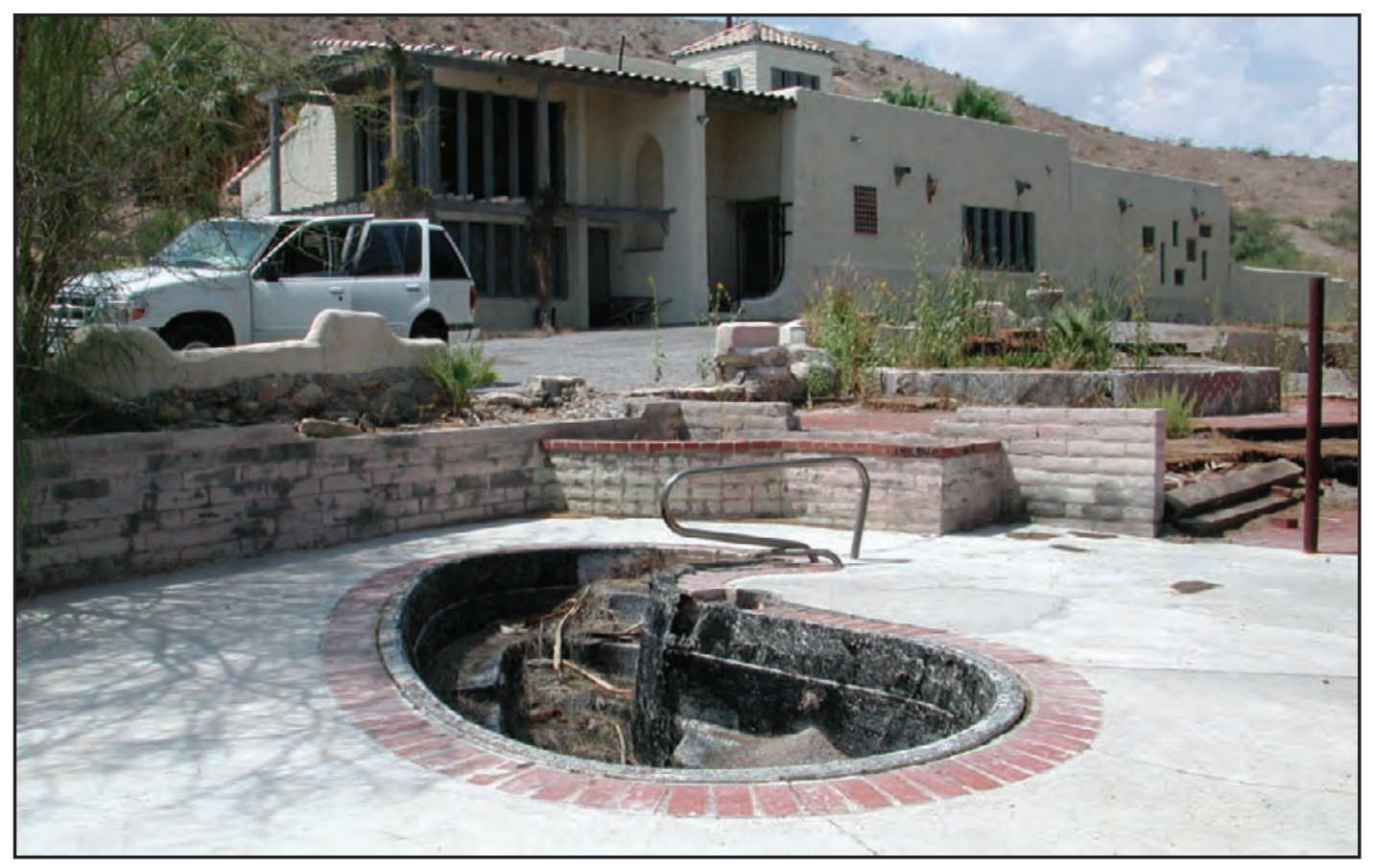

Figure A8. View of the spa and mansion at the former Desert Oasis Warm Springs resort in the Warm Springs area near Moapa, Nevada. Photographed in July 2004 by D. Beck. 


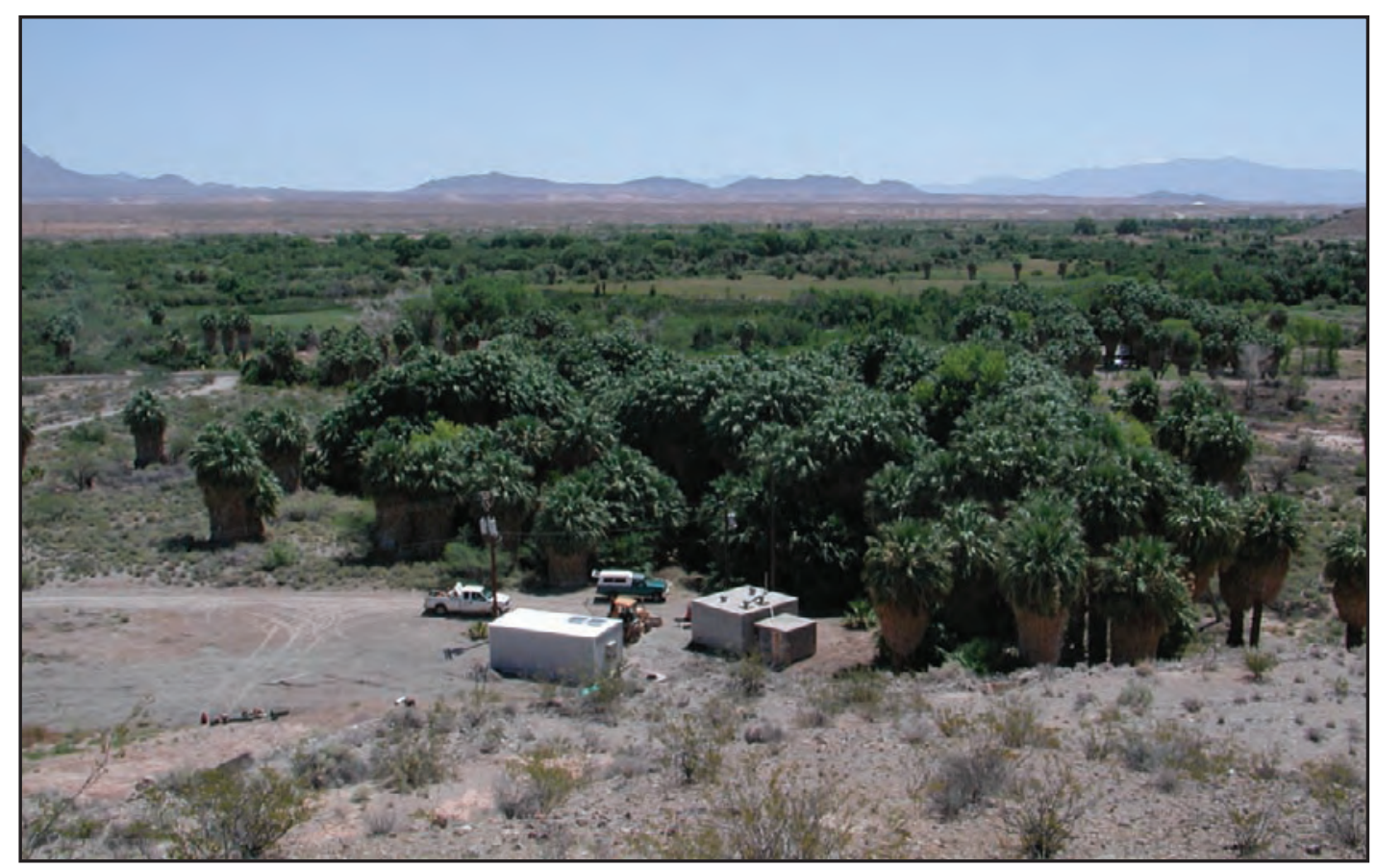

A. View of Moapa Valley Water District's old (right) and new (left) pump houses in the foreground.

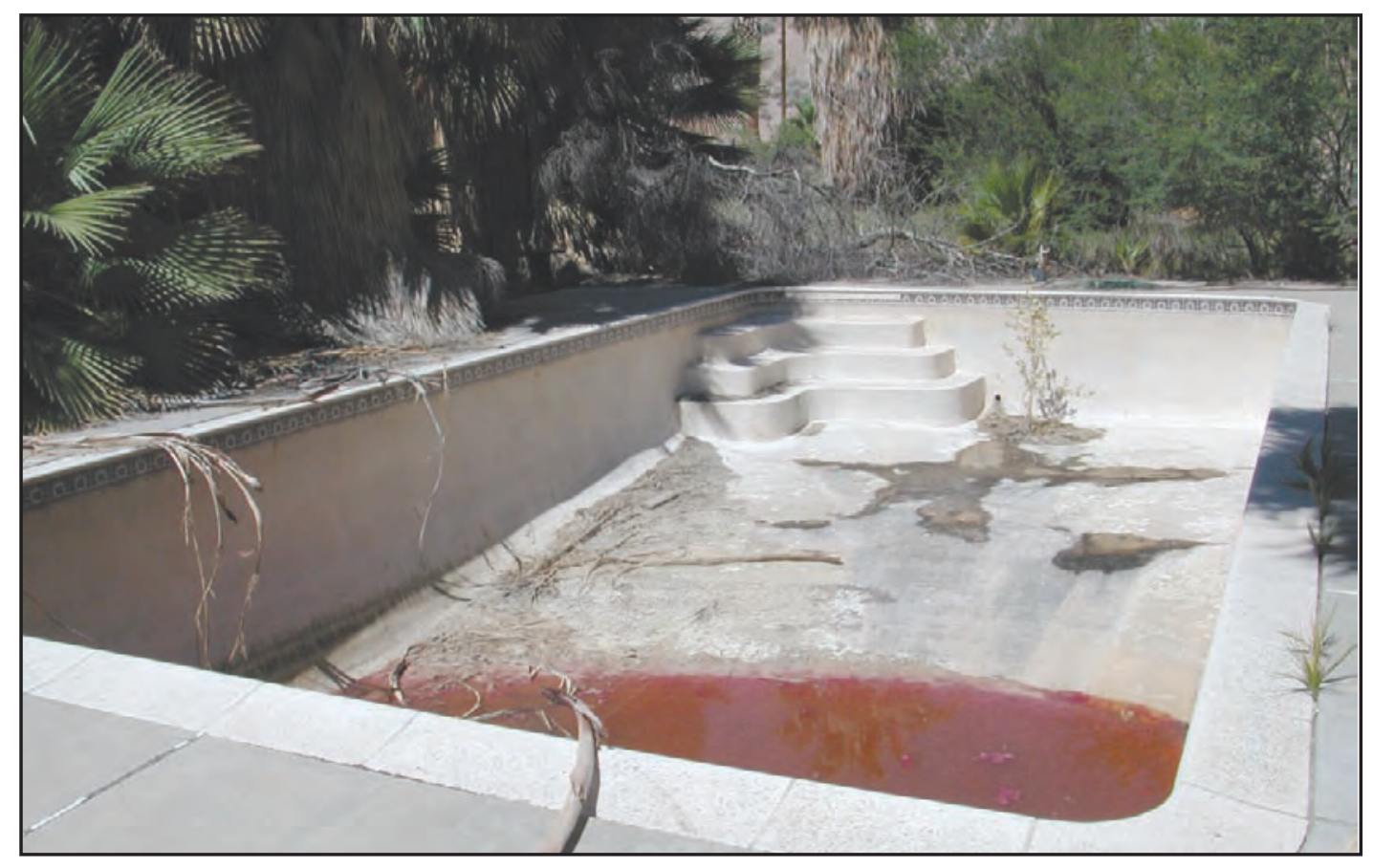

B. View of former swimming pool built by Frederick Apcar around 1980.

Figure A9. View of Apcar (Pipeline Jones) Springs in the Warm Springs area near Moapa, Nevada. Both views photographed in June 2004 by D. Beck. 


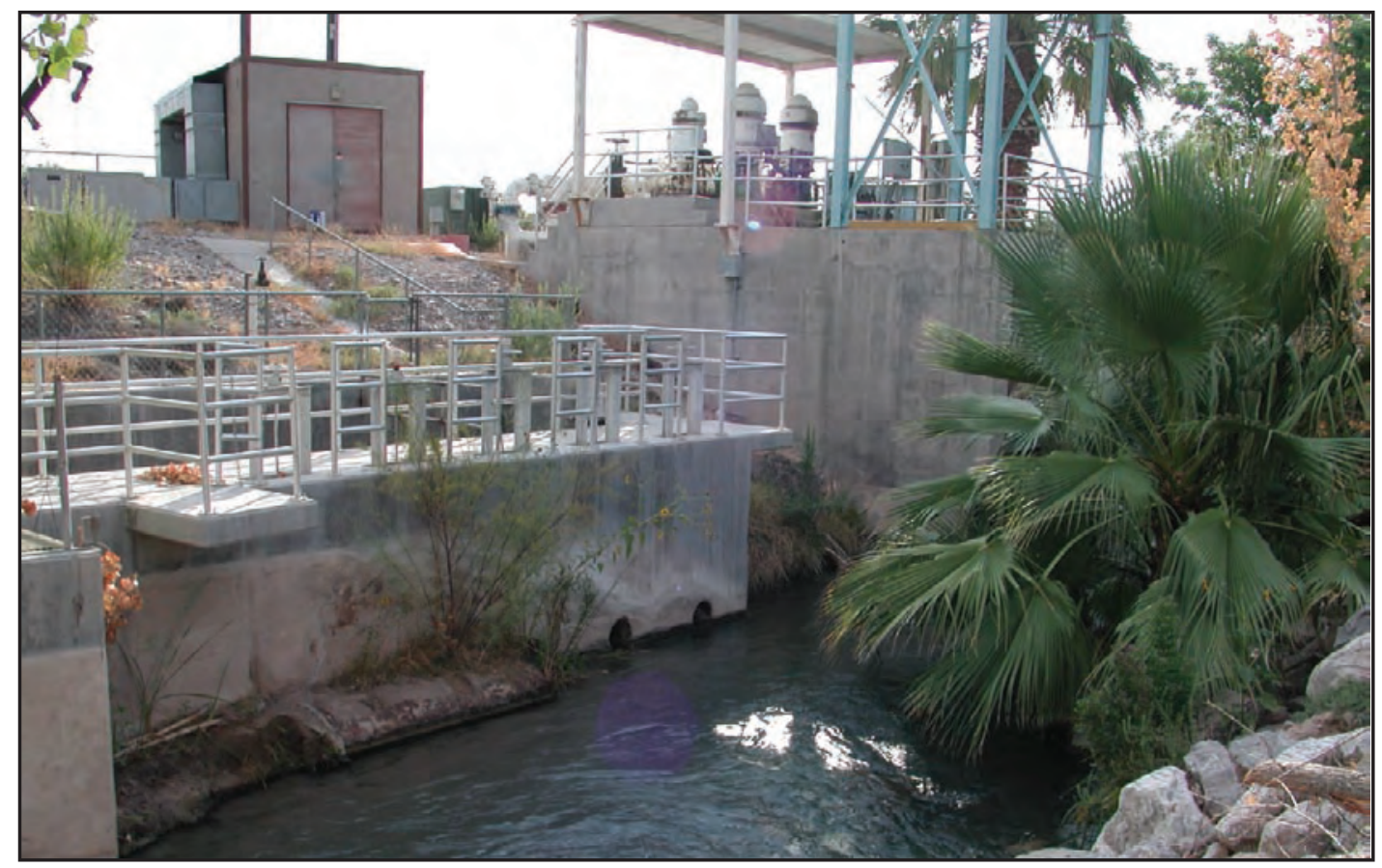

Figure A10. View looking downstream at Nevada Power Company water diversion and pumping station on the Muddy River, in the Warm Springs area near Moapa, Nevada. The diversion is about 100 feet upstream of the U.S. Geological Survey streamflow-gaging station at Warm Springs Road. Photographed in February 2004 by D. Beck.

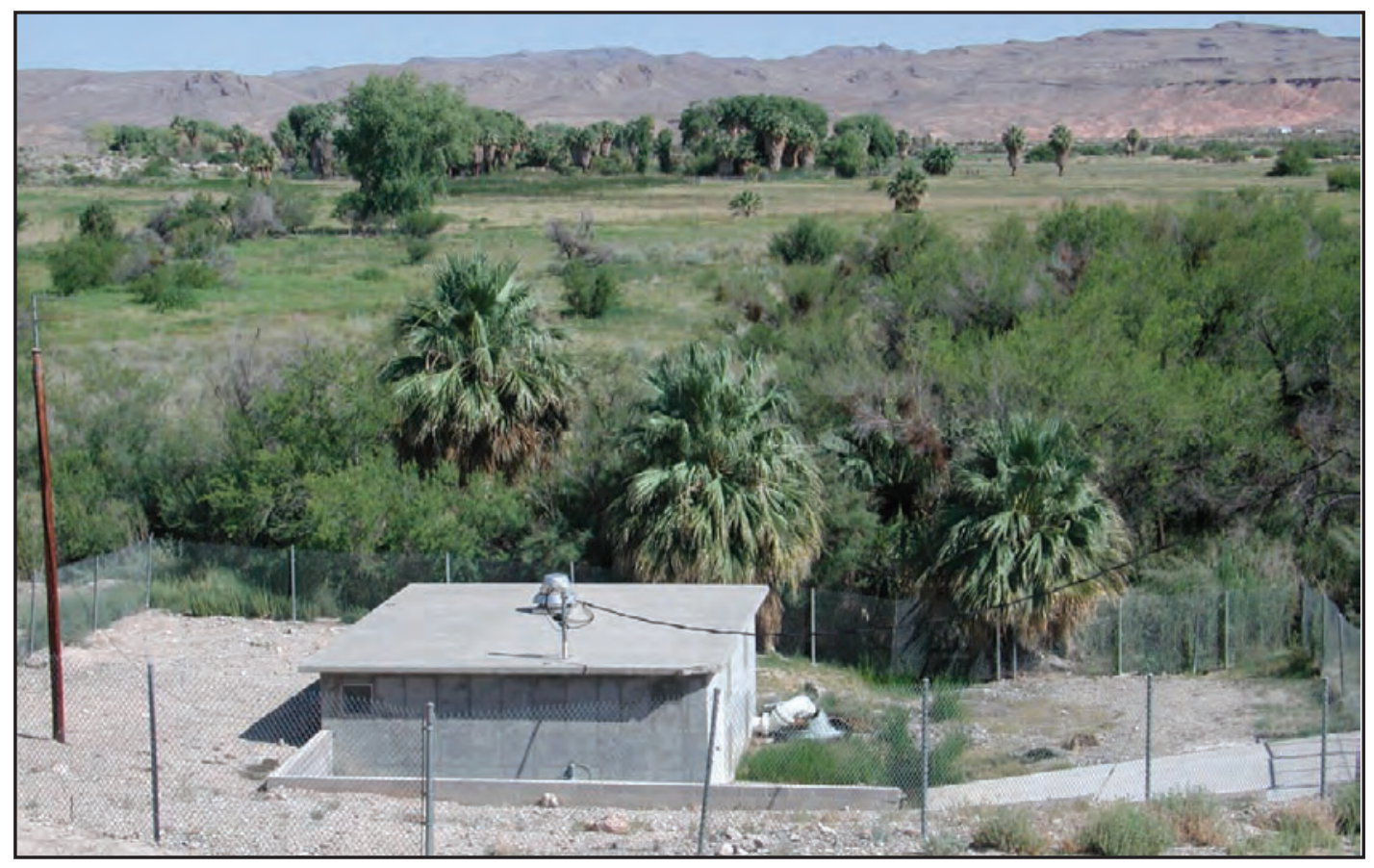

Figure A11. View of the Baldwin Springs area and the Moapa Valley Water District pump house in the Warm Springs area near Moapa, Nevada. Photographed in June 2004 by D. Beck. 


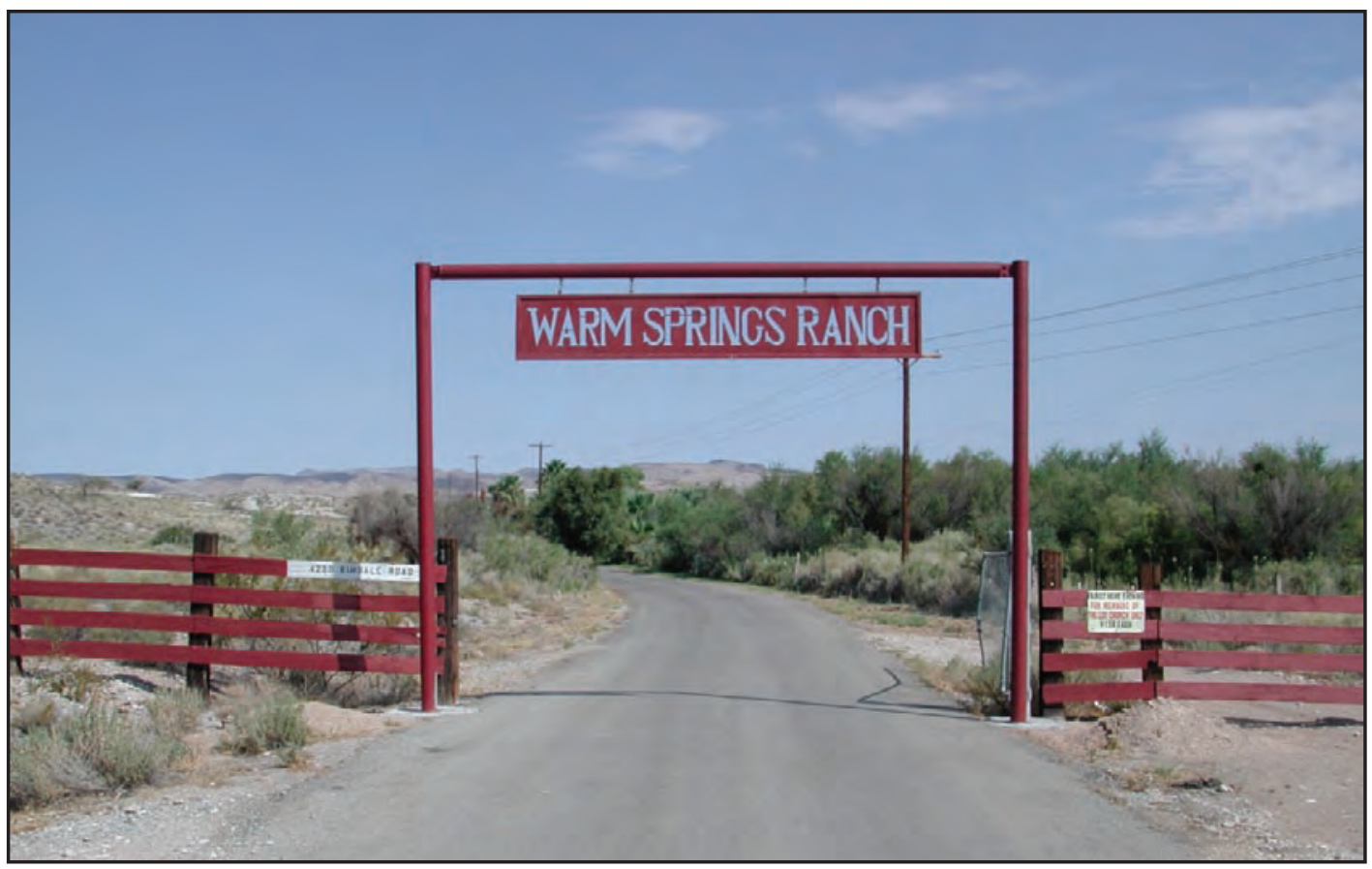

\section{A. Entrance to the recreation area.}

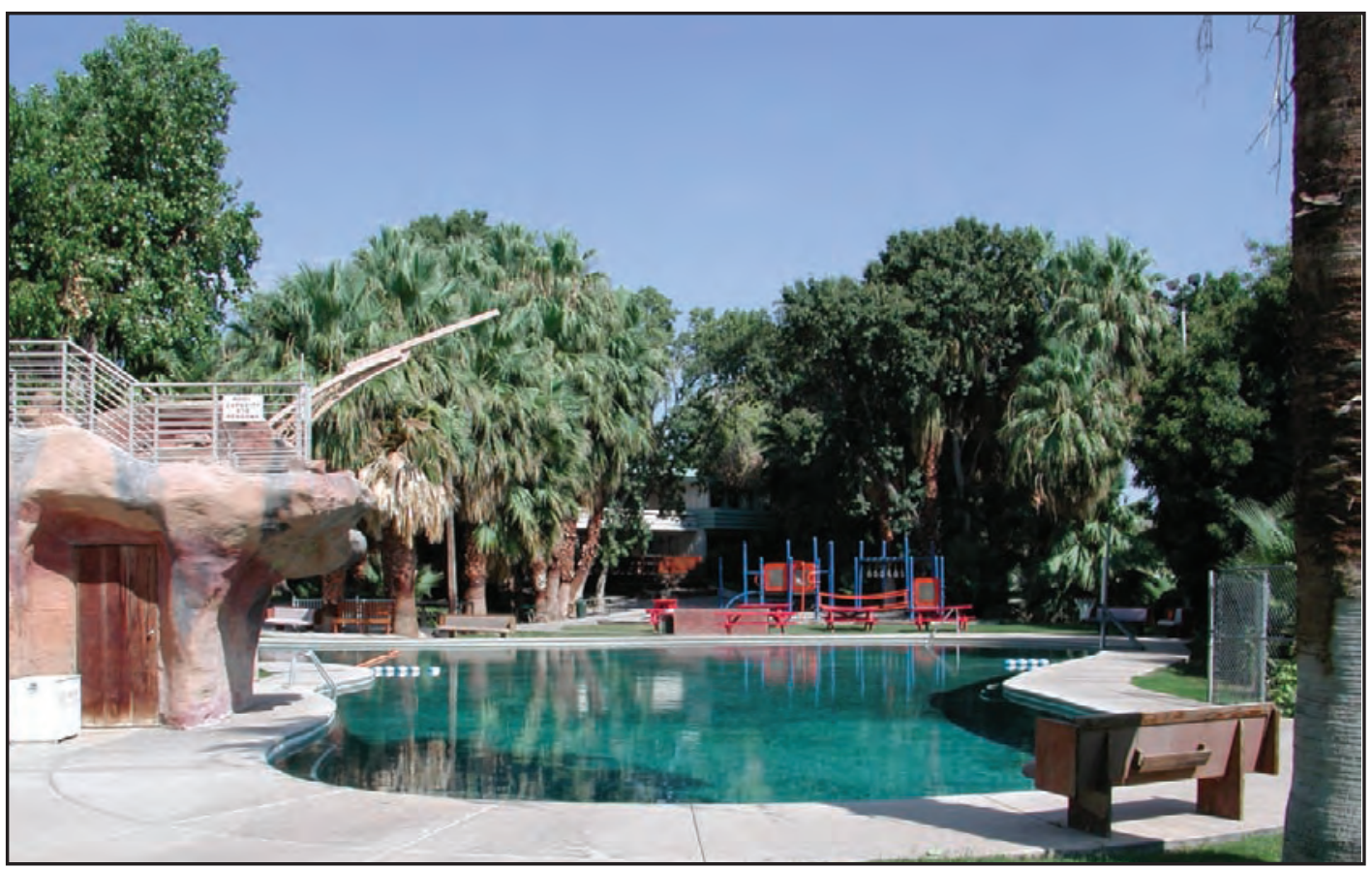

\section{B. Swimming pool in the recreation area.}

Figure A12. Church of the Latter Day Saints Recreational Area in the Warm Springs area near Moapa, Nevada. Both views photographed in June 2004 by D. Beck. 


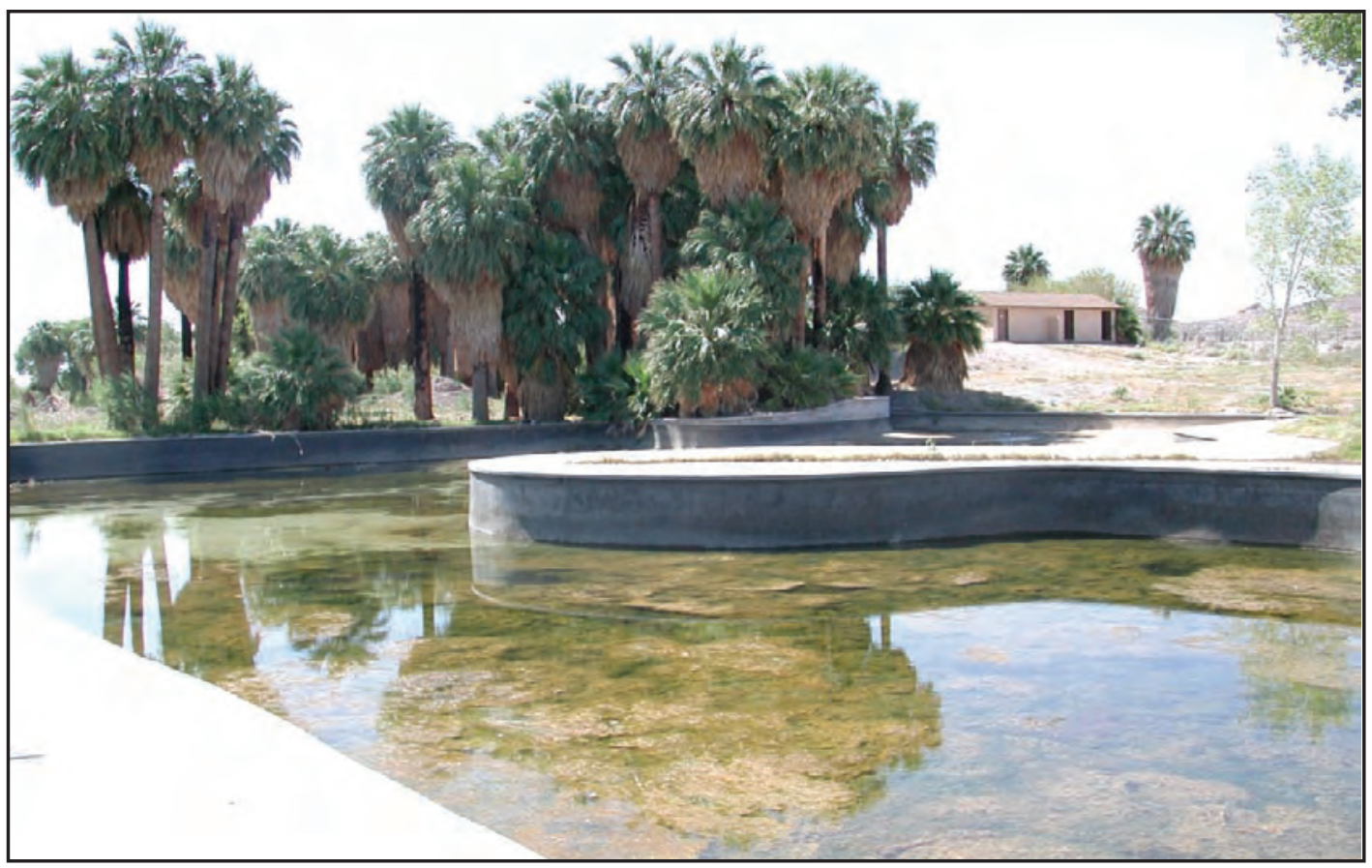

A. View of spring-fed pond and bathhouse, with pond nearly drained. Photographed in June 2004. Photographed in June 2004 by D. Beck.

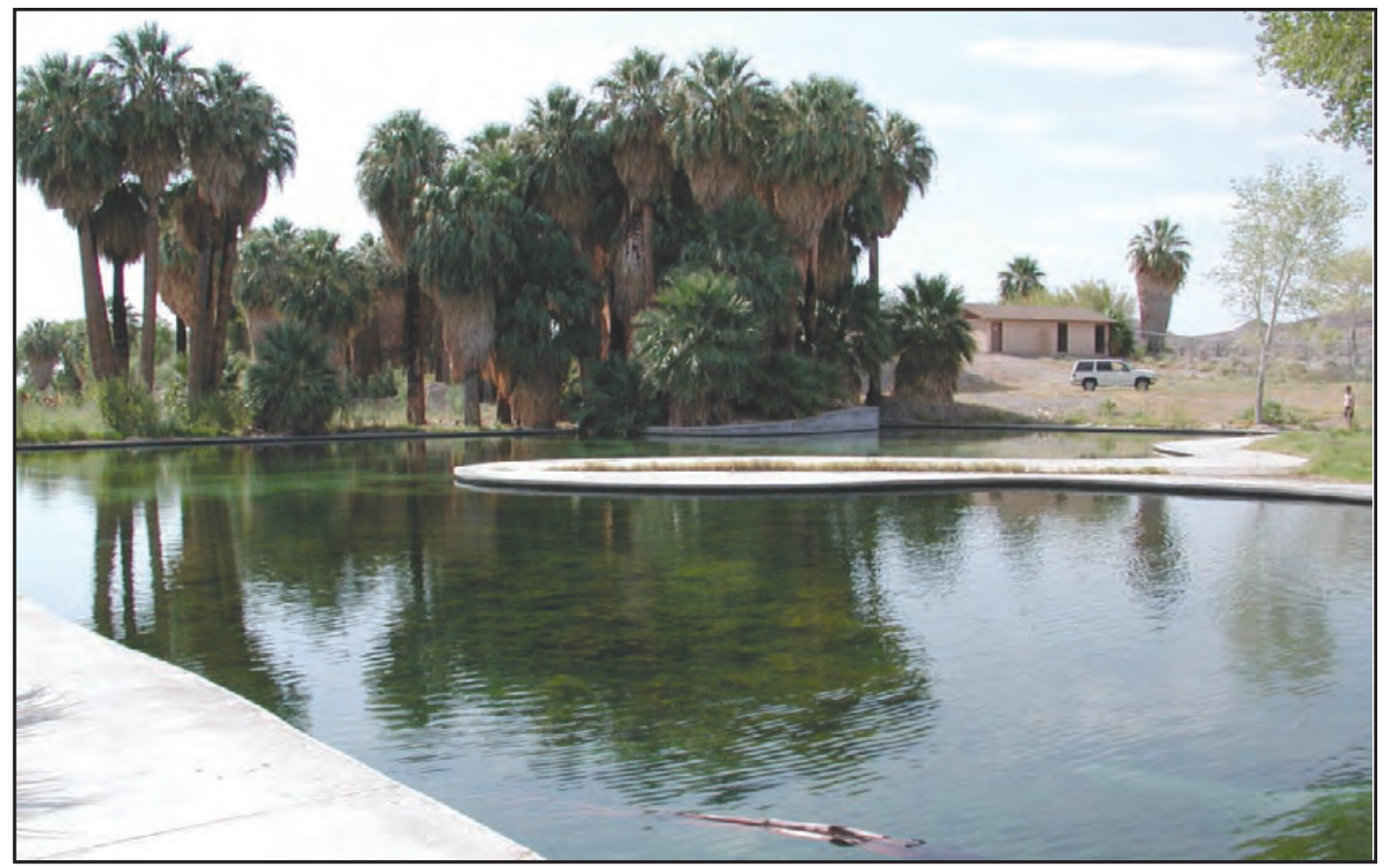

B. View of pond when fully filled. Photographed in September 2004 by D. Beck.

Figure A13. Church of the Latter Day Saints Recreation Area at Cardy Lamb Springs, in the Warm Springs area, near Moapa, Nevada. 
1976

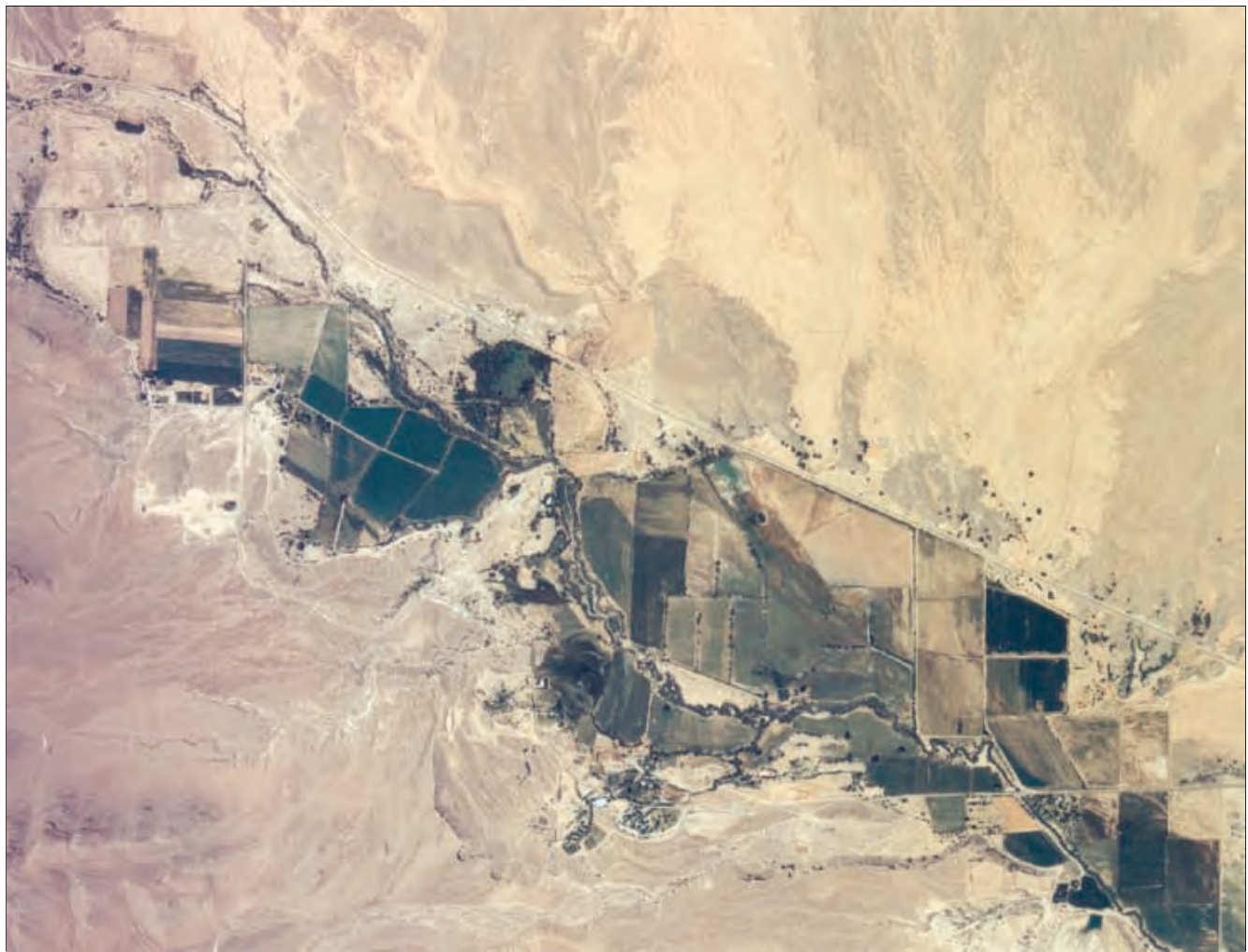

2003

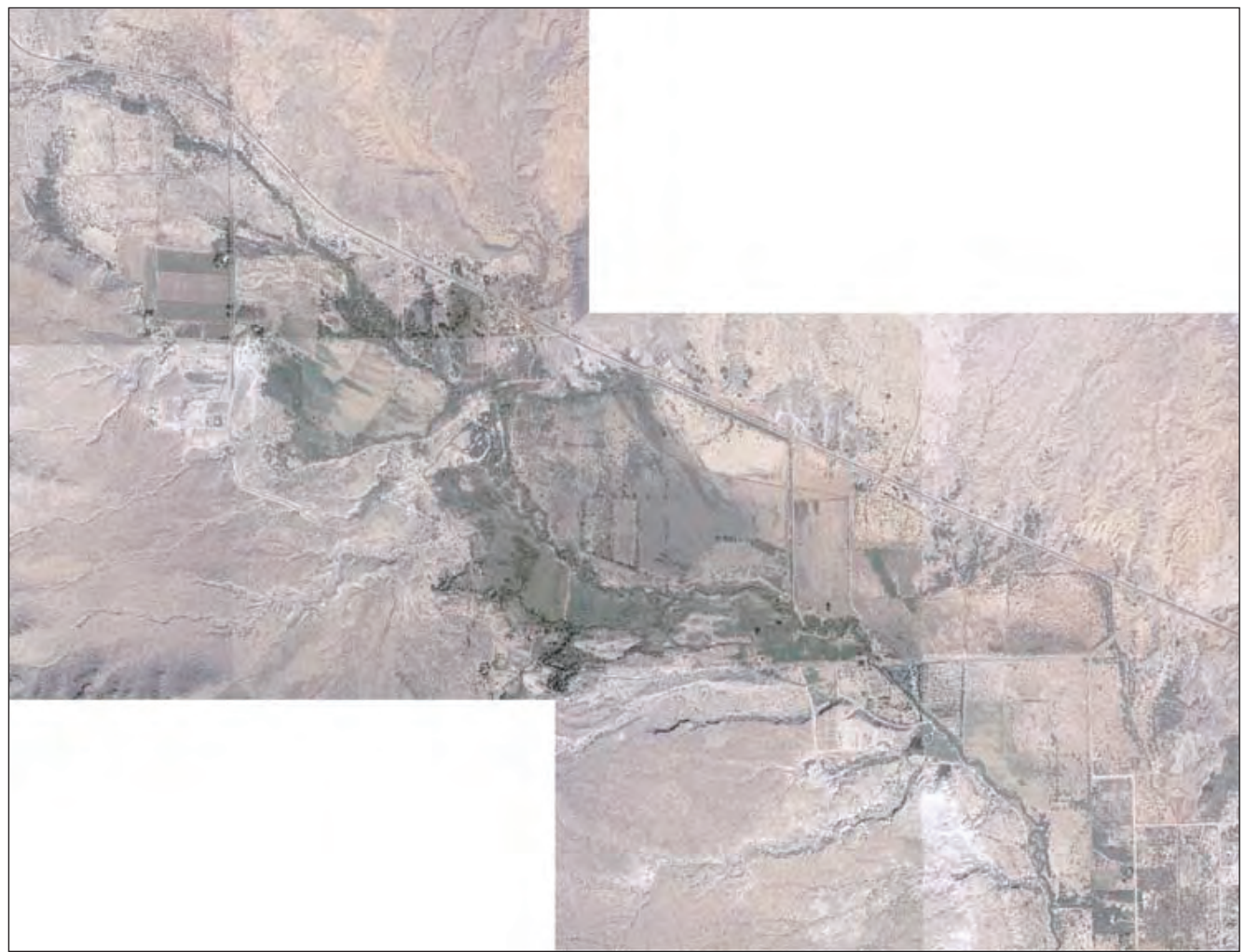

Figure A14. Irrigated acreage in the Warm Springs area near Moapa, Nevada, in 1976 and 2003. 
This page left intentionally blank. 

Appendix B. Water-Level, Discharge, and Water-Quality Data for Selected Monitoring Sites Within the Warm Springs Area Near Moapa, Nevada 
This page left intentionally blank. 


\section{Muddy River}

The following sites are included within this section:

09416000 Muddy River near Moapa, Nevada (1913-2004)

Big Wash Flume near Moapa, Nevada (1967-84)

09415950 Muddy River Power Diversion near Moapa, Nevada (1978-85) 


\section{Muddy River near Moapa, Nevada}

The stream-gage at Muddy River near Moapa originally was established by the Muddy Valley Irrigation District (MVID) on July 1, 1913, at its present location upstream of Warm Springs Road (fig. B1). Water-level record and discharge measurements were collected by the MVID from July 1913 to September 1915 and from April 1916 to September 1918. The gage was reactivated in June of 1928 by the University of Nevada Agricultural Experiment Station (UNAES). Daily mean gage height and monthly discharge were collected by the UNAES from June 1928 to October 1931 and from April 1932 to July 1932. The Bureau of Reclamation (Reclamation) reactivated the gage October 21, 1944, and collected continuous streamflow data until October 1, 1948, when the operation of the gage became the responsibility of the U.S. Geological Survey. Flow is diverted about $100 \mathrm{ft}$ upstream of the gage by the Nevada Power Company for use at the Reid Gardner Generating Station about $3 \mathrm{mi}$ downstream of the gage (fig. 1). The hydraulic control for this site is the $10-\mathrm{ft}$ concrete Cipolletti weir, which was installed by the USBR in 1944 just upstream from the Warm Springs Road crossing (fig. B2).

Daily mean discharges for the period of record are plotted on figure B3 and listed in table B1. Photographs of the bench and reference marks established for this gage on June 2, 2004, are shown in figure B4. 


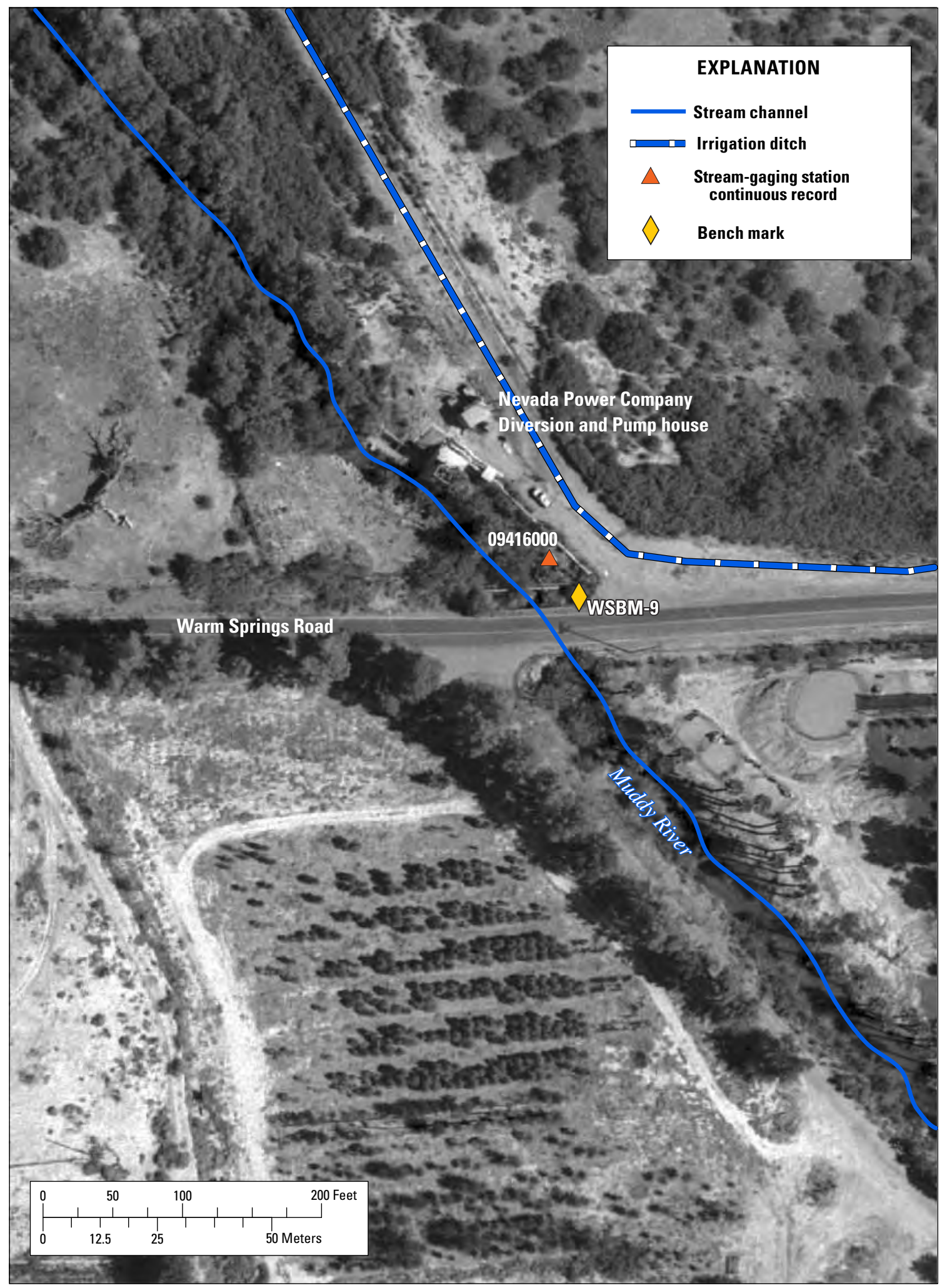

Figure B1. Location of Muddy River stream-gaging station (09416000), bench mark WSBM-9, and Nevada Power Company's diversion and pump house in the Warm Springs area near Moapa, Nevada. 


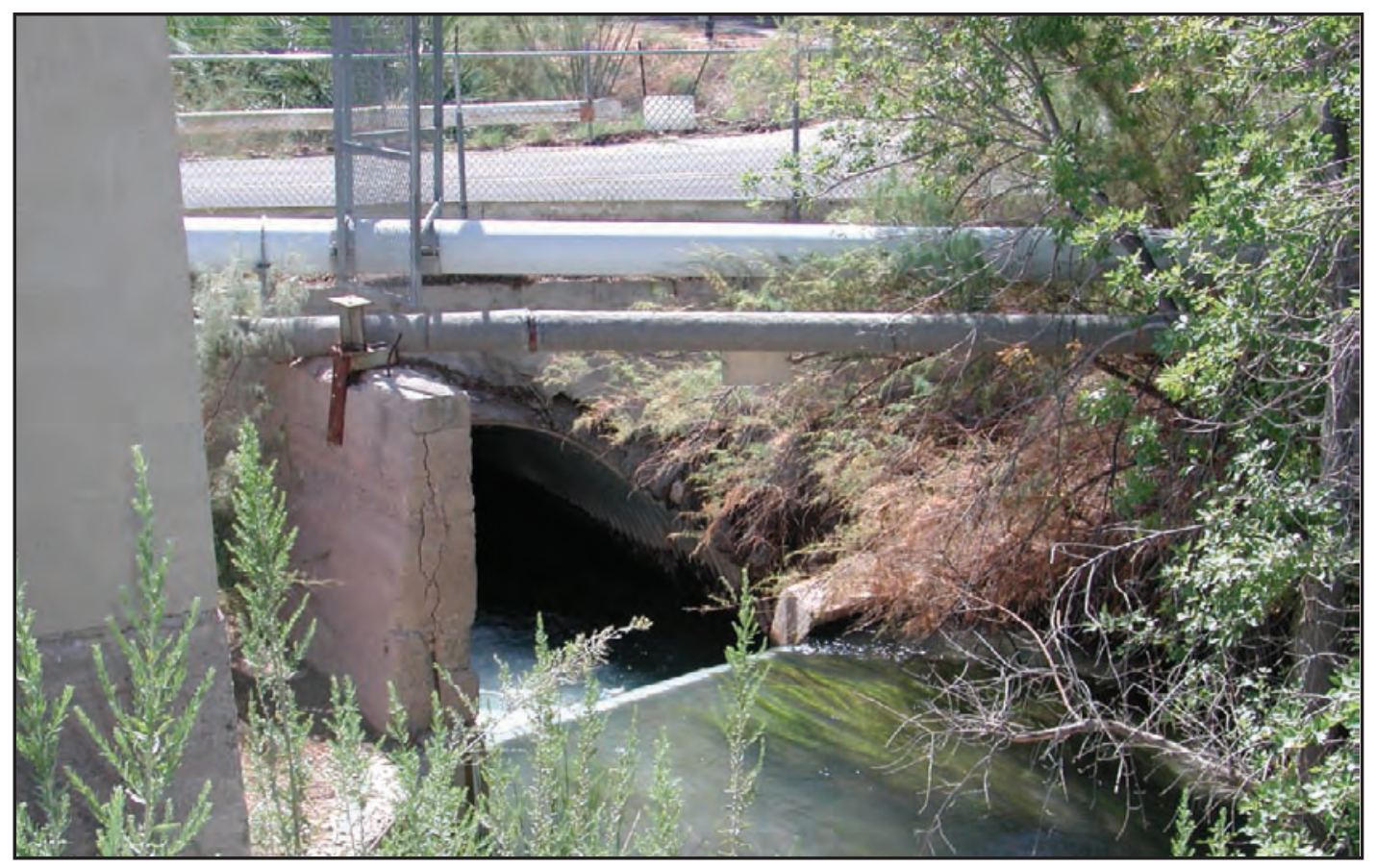

Figure B2. View looking downstream of the Cipolletti weir upstream of Warm Springs Road at the Muddy River stream-gaging station (09416000) in the Warm Springs area near Moapa, Nevada. Photographed in June 2004 by D. Beck. 

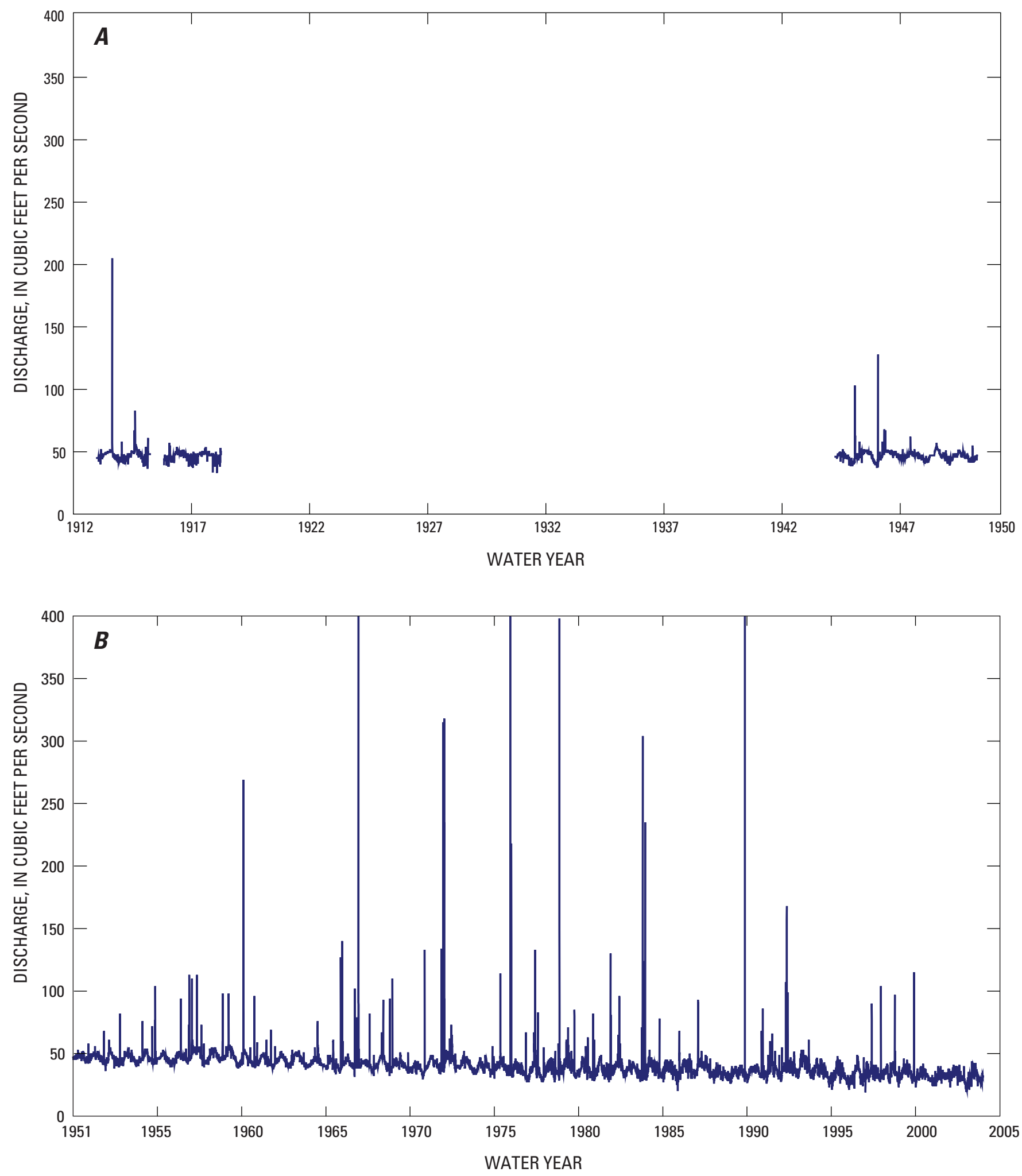

Figure B3. Daily mean discharges for stream-gaging station 09416000, Muddy River near Moapa, Nevada, for $(A)$ water years 1913-15, 1916-18, and 1944-47, and (B) water years 1951-2004. 
42 Water-Surface Elevations, Discharge, and Water-Quality Data in the Warm Springs Area near Moapa, Nevada

Table B1. Daily mean discharges for continuous-recording stream-gaging station 09416000 Muddy River near Moapa, Nevada, water years 1913-2004.

Table B1 data are available in an Excel data base for download at URL: http://pubs.water.usgs.gov/ofr2006-1311. 


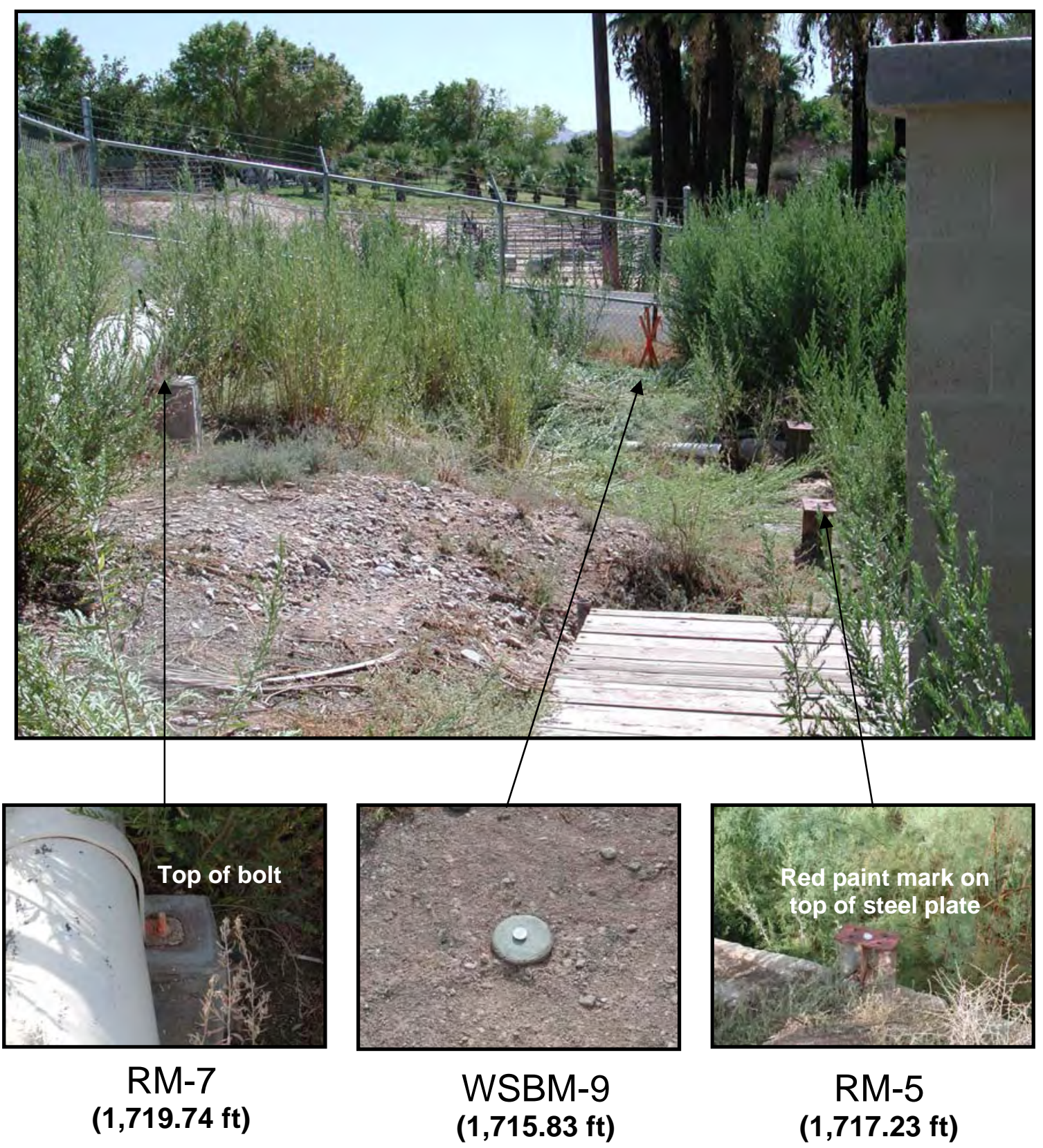

Figure B4. Location and elevation of bench mark WSBM-9 and reference marks RM-5 and RM-7 at streamgaging station 09416000, Muddy River near Moapa, Nevada, June 2, 2004, elevation in feet above NGVD 88. Photographed by D. Beck. 


\section{Big Wash Flume near Moapa, Nevada}

A 3-ft Parshall flume was installed on Big Wash (North Fork Muddy River) on October 11, 1967, by the Nevada Division of Water Resources (NDWR). The flume was located approximately $500 \mathrm{ft}$ upstream of the confluence with South Fork Muddy River (fig. B5). The source of water in the river originates from springs and seeps located in the uppermost northwest drainage of the Warm Springs area.

Data provided by NDWR show that water levels in the flume were generally measured monthly from October 11 , 1967 to July 18, 1984. Several gaps occur in the record, the largest two occurring from March 1969 to February 1974 and from May 1981 to March 1984. Information provided by NDWR did not indicate whether a new flume had been installed after any of these gaps, but the information did note that a 3 -ft flume was in use for the entire period of record. The former flume site was visited by the U.S. Geological Survey on September 16, 2004, and a 3-ft steel Parshall flume was observed upside down on the south bank of the river (fig. B6).

As only water-level measurements were provided by NDWR, discharge rates were computed using a standard rating equation for the 3 -ft Parshall flume (Leupold and Stevens, 1987). A plot of the computed discharges from October 1967 to July 1984 is shown in figure B7. A complete listing of the water-level measurements and computed discharges are included in table B2. Discharges computed from October 1967 to March 1969 are substantially less than the computed discharges for the remainder of the period. Although flow may have been bypassing the flume at that time, documentation was unavailable to verify it. 


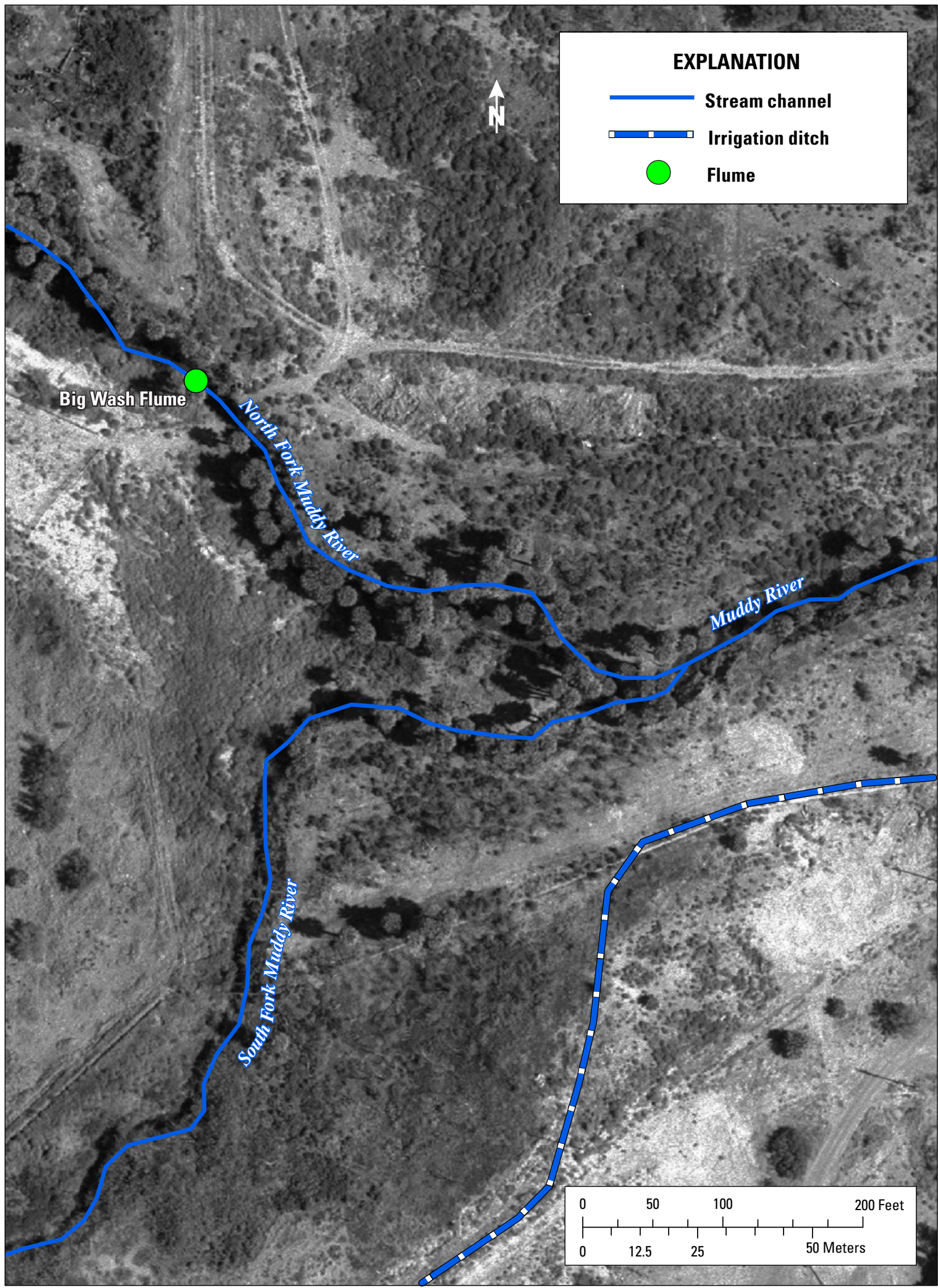

Figure B5. Location of former Big Wash flume site on the North Fork Muddy River in the Warm Springs area near Moapa, Nevada. 


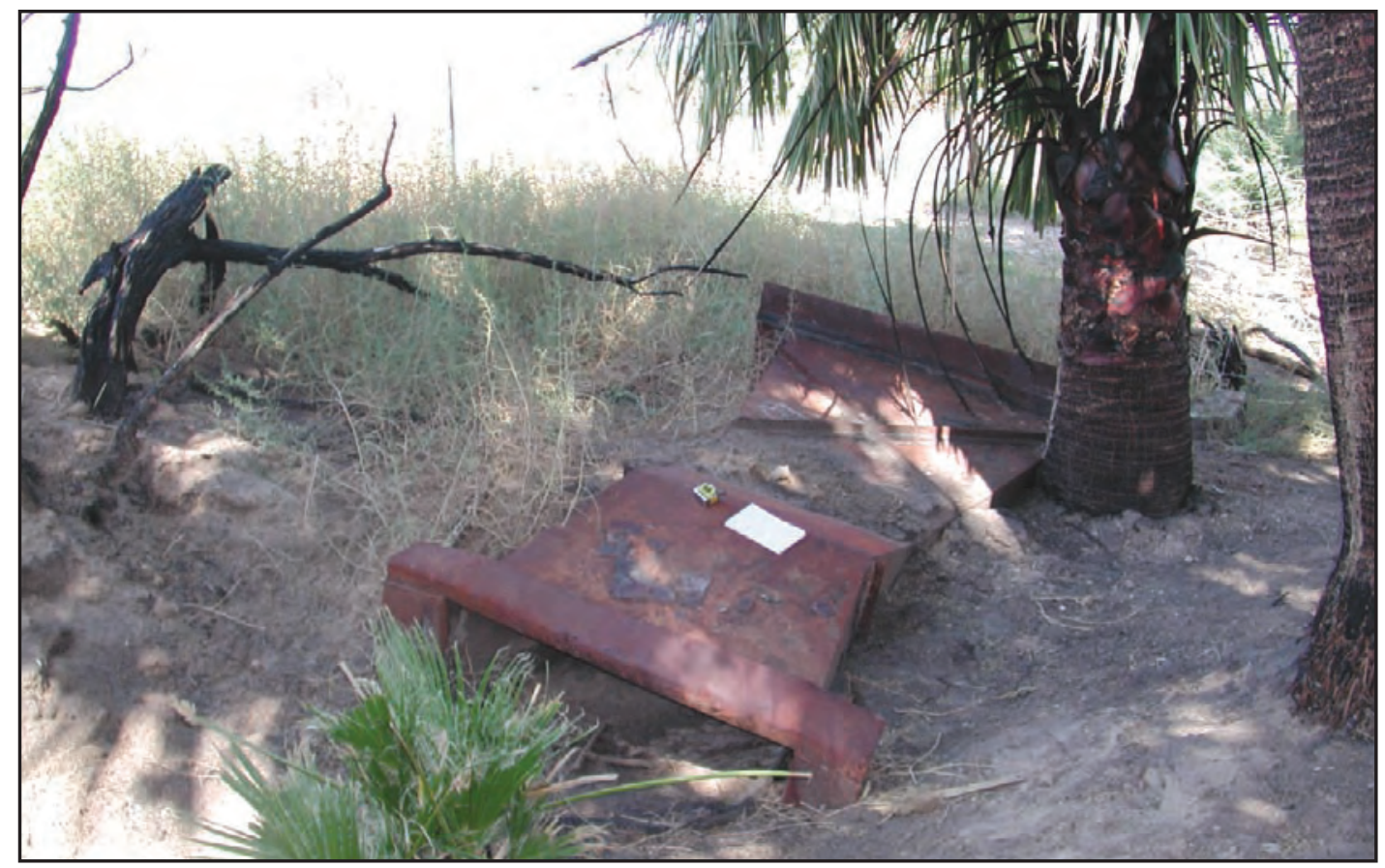

Figure B6. Former Big Wash flume on right bank of North Fork Muddy River in the Warm Springs area, near Moapa, Nevada. The flume is about 500 feet upstream of confluence with South Fork Muddy River. Photographed in September 2004 by D. Beck.

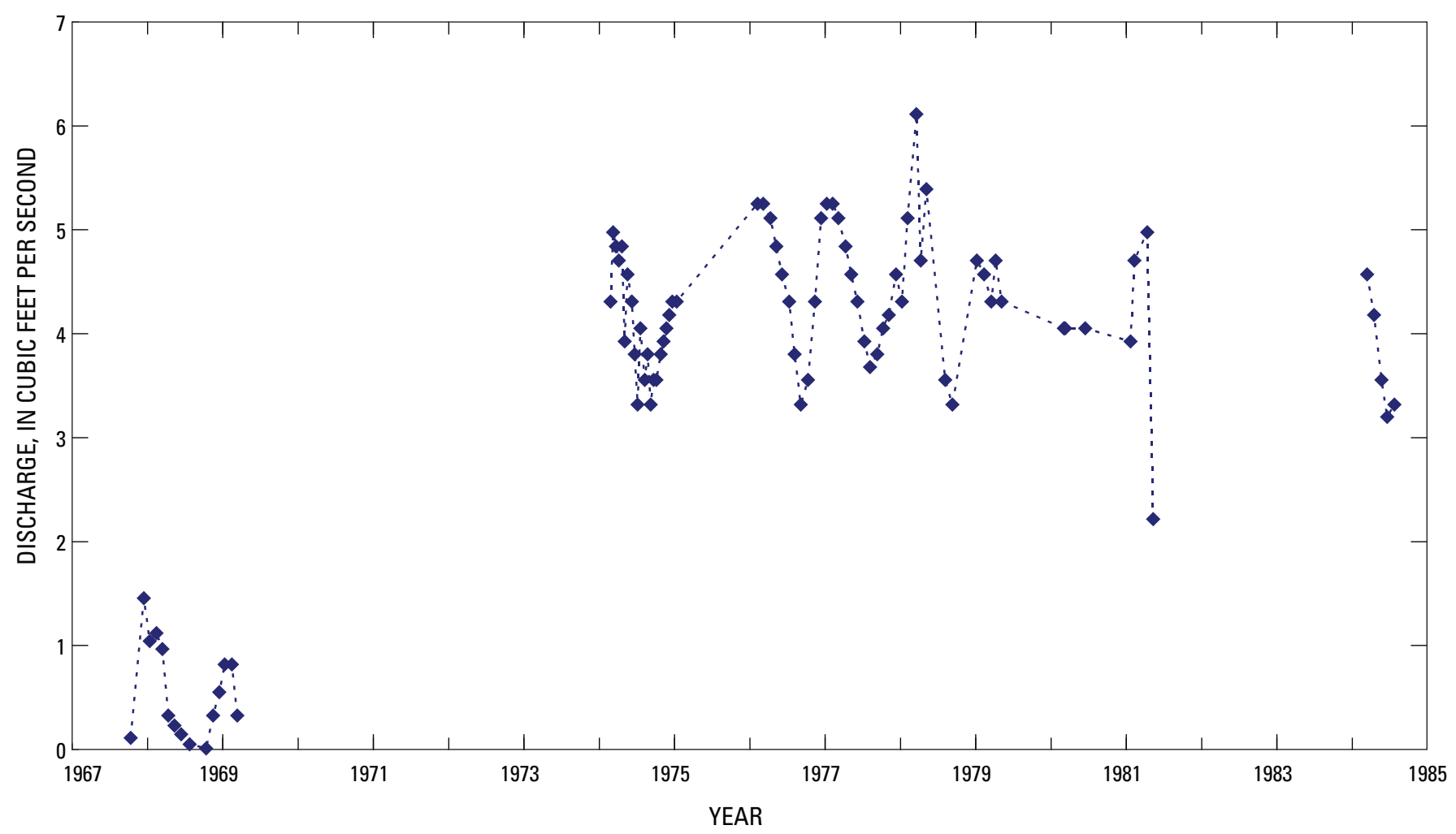

Figure B7. Instantaneous discharges for the Big Wash flume in the Warm Springs area near Moapa, Nevada, 1967-69, 1974-81, and 1984. 
Table B2. Water levels and instantaneous discharges for Big Wash flume, near Moapa, Nevada, 1967-84.

Table B2 data are available in an Excel data base for download at URL: http://pubs.water.usgs.gov/ofr2006-1311. 


\section{Muddy River Power Diversion and Pump House near Moapa, Nevada}

In the early 1970s, the Nevada Power Company (NPC) constructed a diversion and pump house along the north bank of the Muddy River approximately $100 \mathrm{ft}$ upstream of the U.S. Geological Survey (USGS) stream-gaging station at Warm Springs Road (fig. B1). Water is pumped directly from the stream and transmitted through a pipeline to the Reid Gardner Generating Station (fig. 1) about 3 mi southeast of the gage. The NPC provided the USGS with pumpage data from October 1, 1977, to September 30, 1985. Daily mean discharges for the period were computed and published in the USGS, Nevada District, annual data report series between water years 1978 and 1986). See figure B8 and table B3 for a graph and a table, respectively, of the daily mean discharges. Annual mean daily discharge from the diversion for water years 1978 to 1985 was $3.45 \mathrm{ft}^{3} / \mathrm{s}$. 


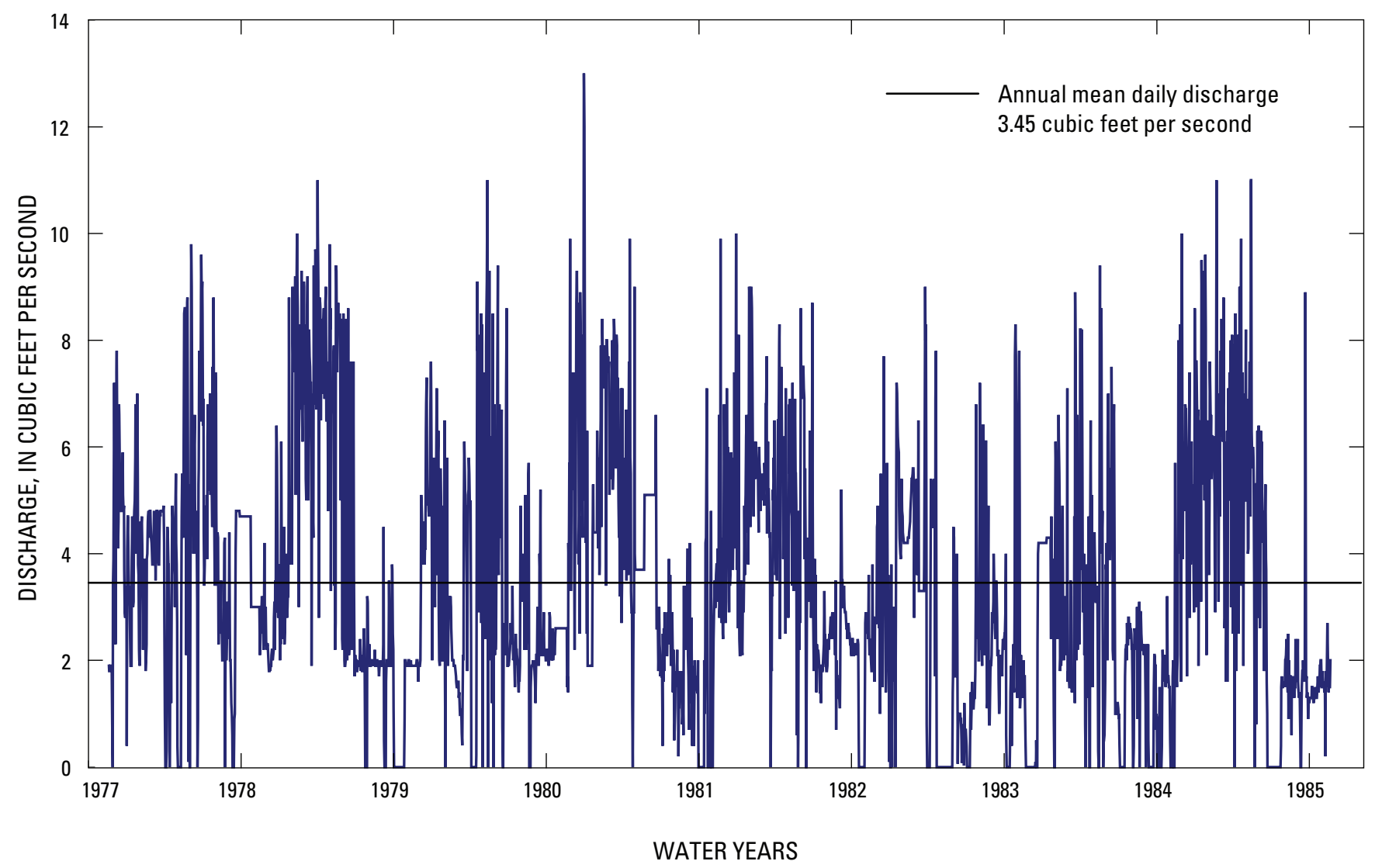

Figure B8. Daily mean discharges for the Muddy River power diversion in the Warm Springs area, near Moapa, Nevada, water years 1978-85. Pumping data was provided to U.S. Geological Survey by Nevada Power Company. 
Table B3. Daily mean discharges for the Muddy River Power Diversion near Moapa, Nevada (09415950), water years 1978-85. $\underline{\text { Table B3 }}$ data are available in an Excel data base for download at URL: $\underline{\text { htp://pubs.water.usgs.gov/ofr2006-1311. }}$ 


\section{Plummer Springs Group}

The following sites are included within this section:

364236114424301 Warm Springs East (Plummer Main) near Moapa, Nevada (1982-2004)

364238114424401 Muddy River Springs 15 (M-15) near Moapa, Nevada (1987-2004)

364238114424201 Muddy River Springs 16 (M-16) near Moapa, Nevada (1987-2004)

364238114424301 Muddy River Springs 20 (M-20) near Moapa, Nevada (1994-2004)

Converse Consultant Water-Quality Site S1a (1997-2004)

Converse Consultant Water-Quality Slte S1b (1997-2004)

Converse Consultant Water-Quality Site S34 (1997-2004)

Converse Consultant Water-Quality Site S42 (1997-2004)

Converse Consultant Water-Quality Site S43 (1997-2004)

Converse Consultant Water-Quality Site-S44 (1997-2004)

Converse Consultant Water-Quality Site-S44a (1997-2004)

Converse Consultant Water-Quality Site S56 (1997-2004) 


\section{Warm Springs East (Plummer Main) near Moapa, Nevada}

The partial-record stream-gaging station at Warm Springs East was established by the U.S. Geological Survey (USGS) on August 2, 1982, and is located about $70 \mathrm{ft}$ downstream of the confluence with Plummer East tributary and about $180 \mathrm{ft}$ upstream of Warm Springs Road (fig. B9). Flow in Warm Springs East is the combined discharge from all springs and seeps on that part of the Moapa Valley National Wildlife Refuge, formerly known as the Desert Oasis Warm Springs Resort. Periodic discharge measurements have been made by the USGS since 1982. Discharge measurements for the period of record are plotted in figure B10 and listed in table B4.
In October 1998, the U.S. Fish and Wildlife Service (FWS) installed a staff plate in the channel and made periodic discharge measurements through May 2002. The FWS discharge measurements are also plotted on figure B10 and are listed in table B5.

Photographs of the staff plate and bench mark, and of the reference mark established by the USGS at the Warm Springs East stream-gaging station on June 10, 2004, are shown in figure B11. 


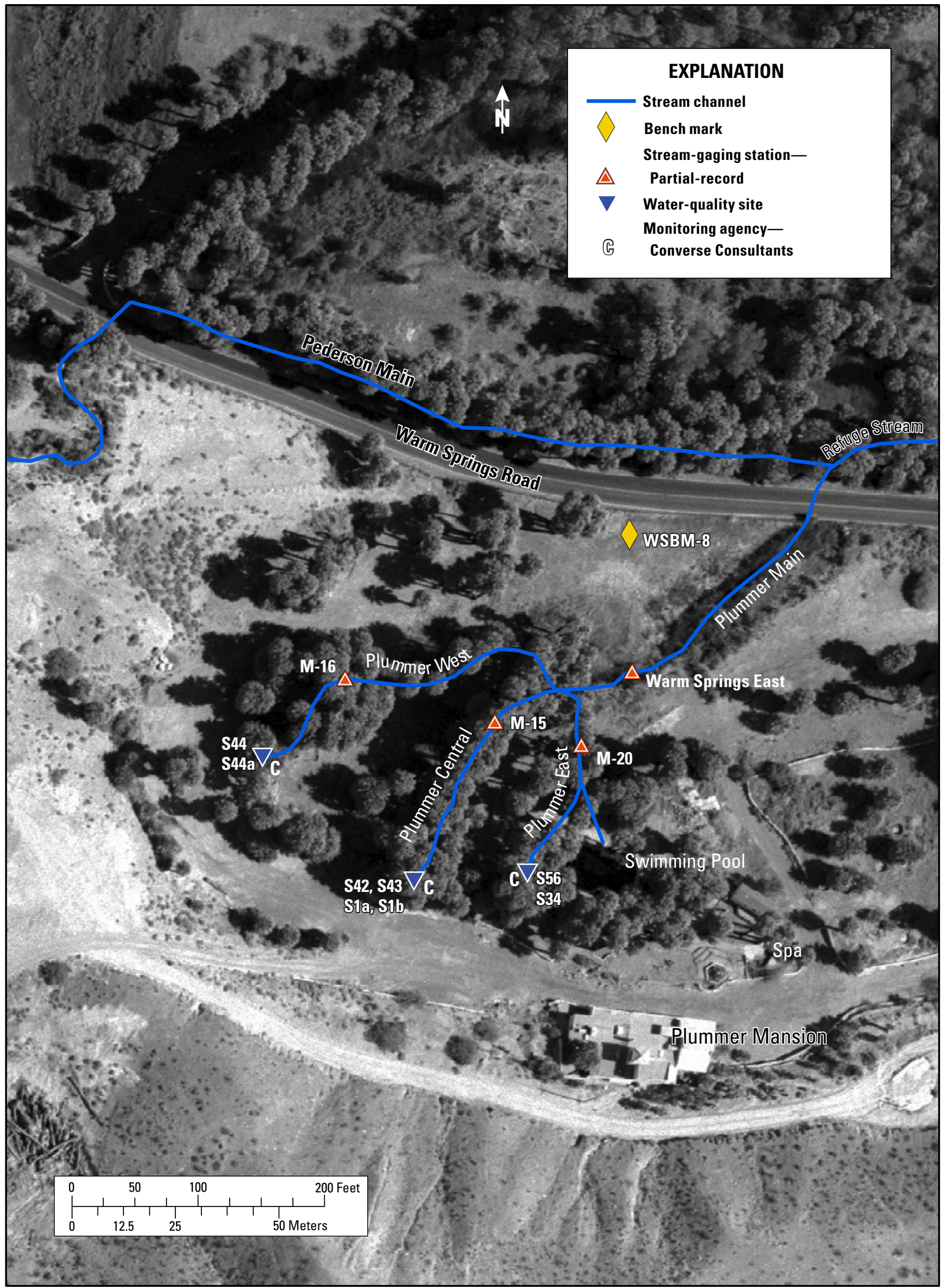

Figure B9. Location of Plummer Springs Group stream-gaging station, monitoring sites, and bench mark WSBM-8 in the Warm Springs area near Moapa, Nevada. 
Water-Surface Elevations, Discharge, and Water-Quality Data in the Warm Springs Area near Moapa, Nevada

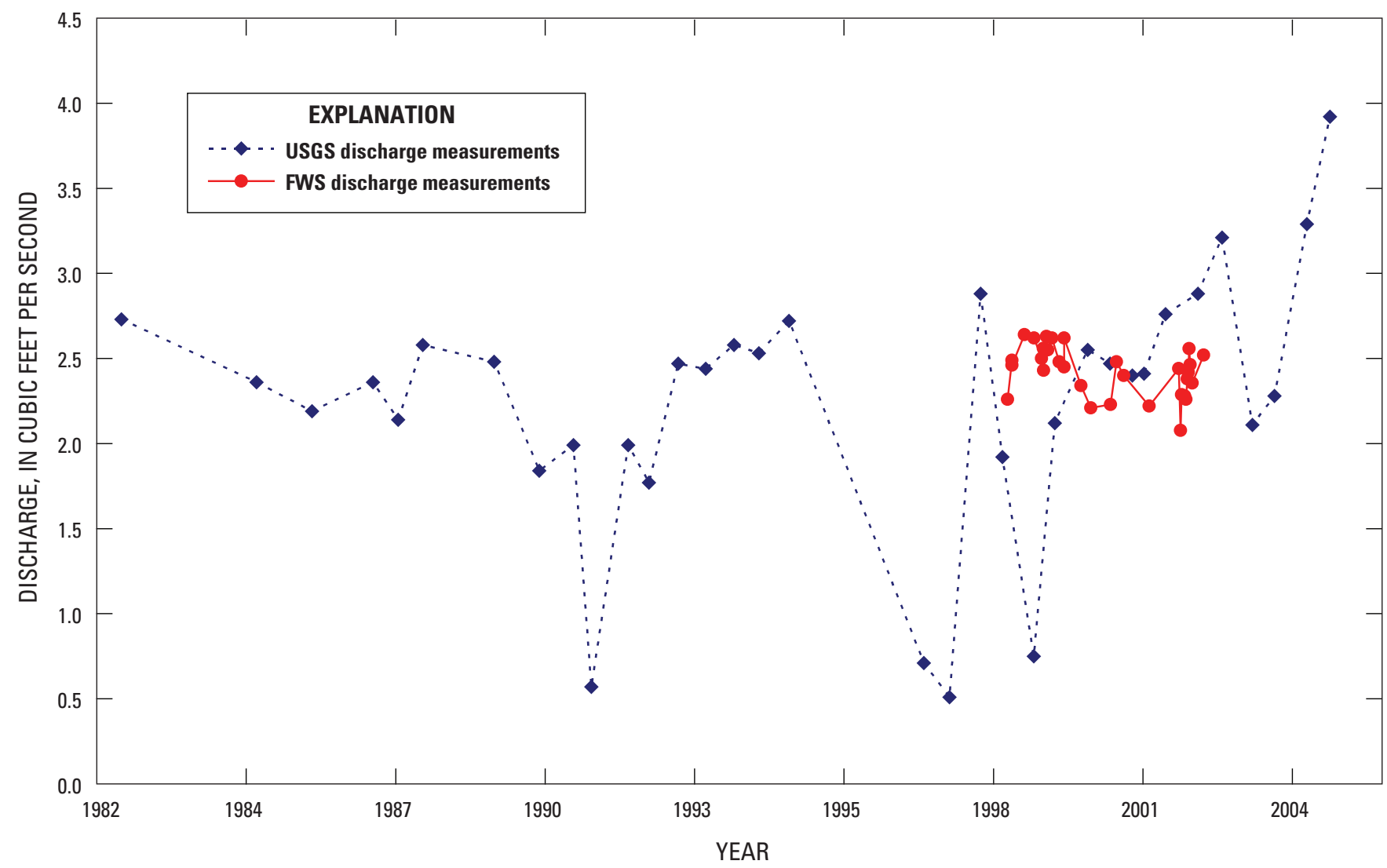

Figure B10. Periodic discharge measurements for partial-record stream-gaging station 364236114424301 Warm Springs East (Plummer Main) near Moapa, Nevada, 1982-2004. Data from U.S. Geological Survey (USGS) National Water Information System (NWIS) database, accessed 2005 at http://waterdata.usgs.gov and U.S. Fish and Wildlife Service (FWS). 
Table B4. Periodic discharge measurements for partial-record stream-gaging station 364236114424301 Warm Springs East (Plummer Main) near Moapa, Nevada, 1982-2004.

[Data from U.S. Geological Survey (USGS) National Water Information System (NWIS) data base, accessed 2005 at http://waterdata.usgs.gov]

Table B4 data are available in an Excel data base for download at URL: http://pubs.water.usgs.gov/ofr2006-1311. 
Table B5. Periodic discharge measurements for partial-record stream-gaging station 364236114424301 Warm Springs East (Plummer Main) near Moapa, Nevada, 1998-2002.

[Data provided by U.S. Fish and Wildlife Service]

$\underline{\text { Table B5 }}$ data are available in an Excel data base for download at URL: $\underline{\text { http://pubs.water.usgs.gov/ofr2006-1311. }}$ 

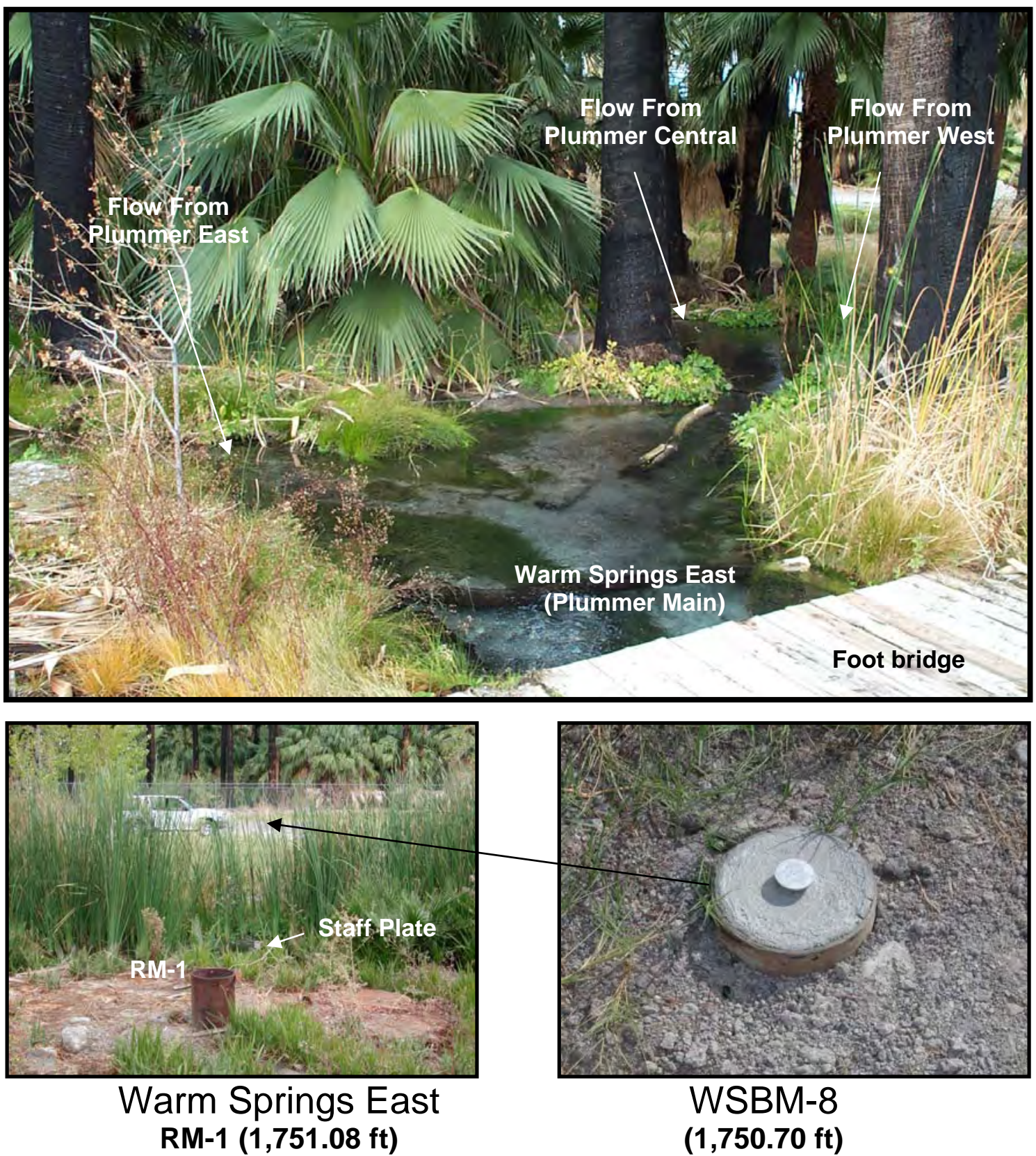

Figure B11. Location of bench mark WSBM-8 and reference mark RM-1 for stream-gaging station 364236114424301 Warm Springs East near Moapa, Nevada. Photographed June 10, 2004 by D. Beck. Elevation bench and reference marks in feet above NAVD 88. 


\section{Muddy River Springs 15 (M-15) near Moapa, Nevada}

The partial-record gaging station at Muddy River Springs 15 (M-15) was established by the U.S. Geological Survey (USGS) on March 12, 1987, and is about $40 \mathrm{ft}$ upstream of the confluence with the Plummer West tributary (fig. B9). Discharge at Muddy River Springs 15 originates upstream from several springs just west of a large swimming pool that was installed by the former Desert Oasis Warm Springs Resort. The area is now part of the Moapa Valley National Wildlife Refuge managed by the U.S. Fish and Wildlife
Service (FWS). The FWS removed many of the former resort's recreational facilities and currently is restoring the springs. Periodic discharge measurements have been made by the USGS since 1987. Discharge measurements for the period of record are plotted in figure B12 and listed in table B6.

Photographs of the staff plate and reference mark established for the Muddy River Springs 15 monitoring site on June 10, 2004, are included in figure B13. 


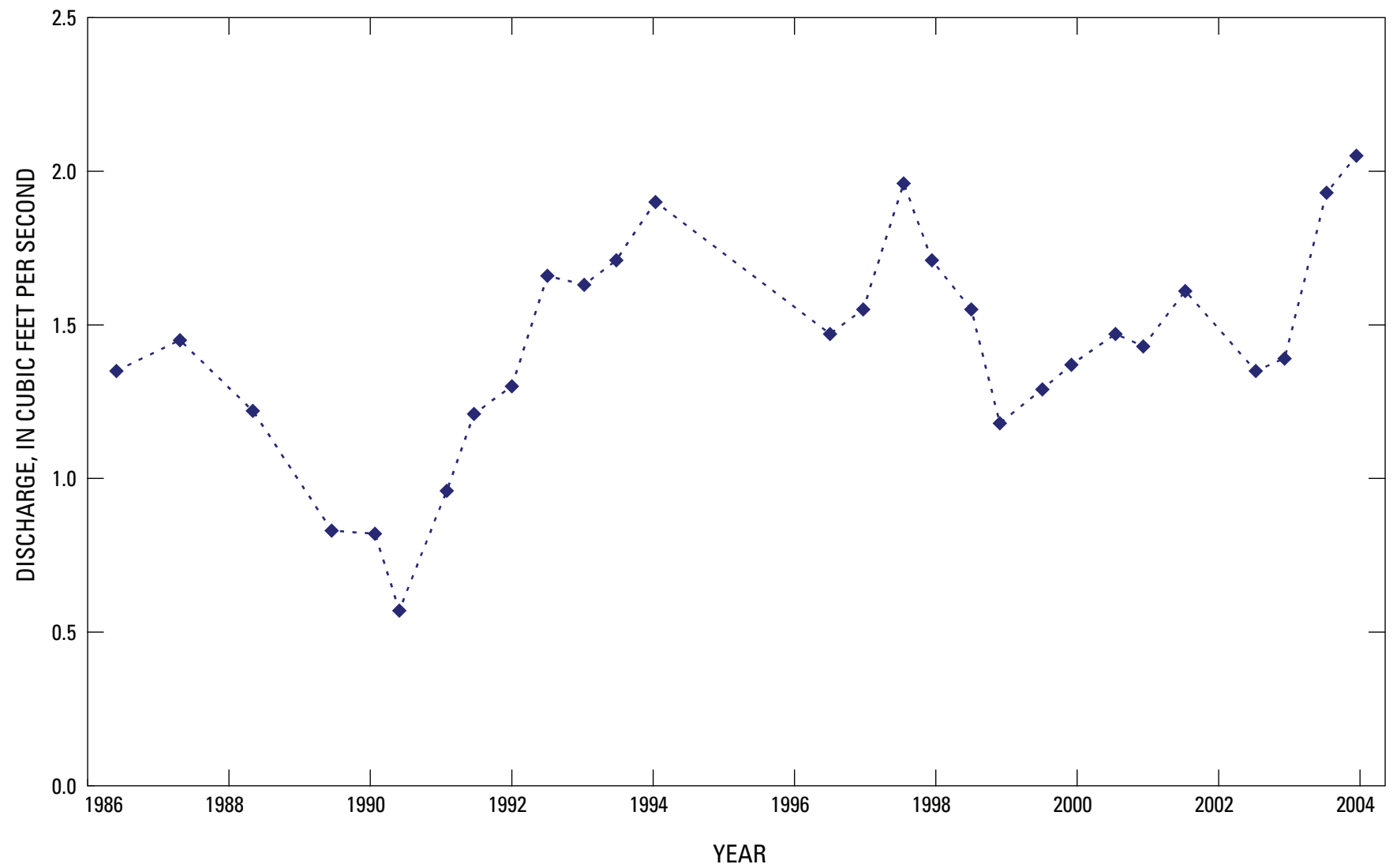

Figure B12. Periodic discharge measurements for partial-record stream-gaging station 364238114424401, Muddy River Springs 15 (M-15) near Moapa, Nevada, 1987-2004. Data from U.S. Geological Survey National Water Information System (NWIS) database, accessed 2005 at http://waterdata.usgs.gov. 
Table B6. Periodic discharge measurements for partial-record stream-gaging station 364238114424401 Muddy River Springs 15 (M-15) near Moapa, Nevada, 1987-2004.

$\underline{\text { Table B6 }}$ data are available in an Excel data base for download at URL: $\underline{\text { http://pubs.water.usgs.gov/ofr2006-1311. }}$ 

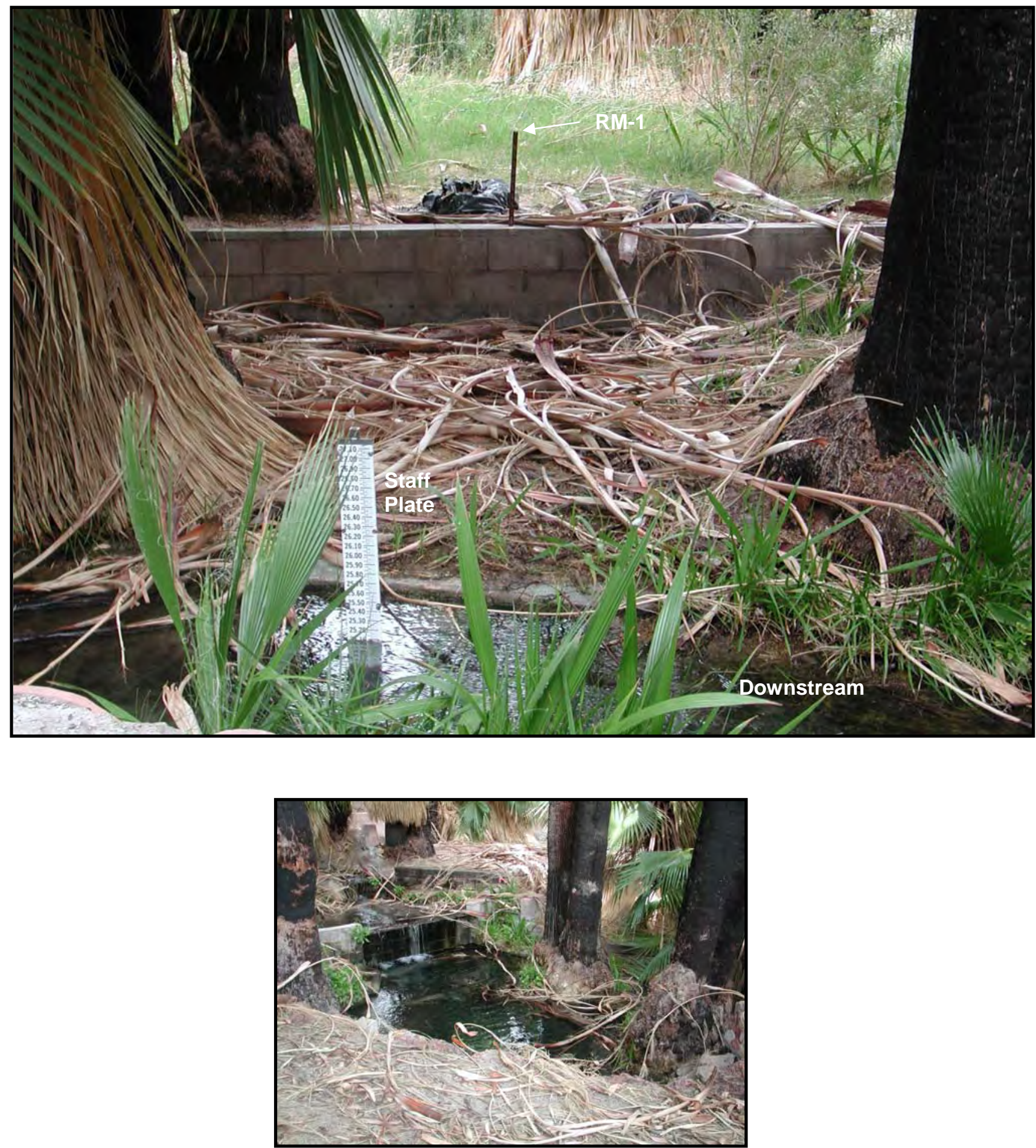

Pond upstream of M-15

Figure B13. Location of staff plate and reference mark (RM-1) at station 364238114424401 Muddy River Springs 15 (M-15) near Moapa, Nevada, and view of upstream pond. Photographed June 10, 2004 by D. Beck. 


\section{Muddy River Springs 16 (M-16) near Moapa, Nevada}

The partial-record gaging station at Muddy River Springs 16 (M-16) was established by the U.S. Geological Survey (USGS) on March 12, 1987, and is about $225 \mathrm{ft}$ upstream of the confluence with the Plummer Central tributary (fig. B9). Discharge at Muddy River Springs 16 originates from a spring-fed pond just upstream of the gage. The area around the spring had previously been developed for trailers and recreational vehicles by the former Desert Oasis Warm Springs Resort. The area is now part of the Moapa Valley National Wildlife Refuge. U.S. Fish and Wildlife Service (FWS) has removed many of the resort's facilities and is currently restoring the springs. Periodic discharge measurements have been made by the USGS since 1987. Discharge measurements for the period of record are plotted in figure B14 and listed in table B7.
In March 1998, the FWS installed a 90-degree v-notch weir and staff plate in the channel. From 1998 to January 2002, FWS made periodic water-level measurements at the weir as well as two measurements of discharge. Discharges for the water-level measurements were computed using a standard weir rating (Rantz, 1982) and are plotted in figure B14. The computed and manual discharge measurements are listed in table B8.

Photographs of the FWS weir and staff plate and of the USGS reference mark established on June 10, 2004, are included in figure B15. On May 26, 2005, the weir, staff plate, and reference mark were observed to have been destroyed as a result of restoration work at the refuge. 


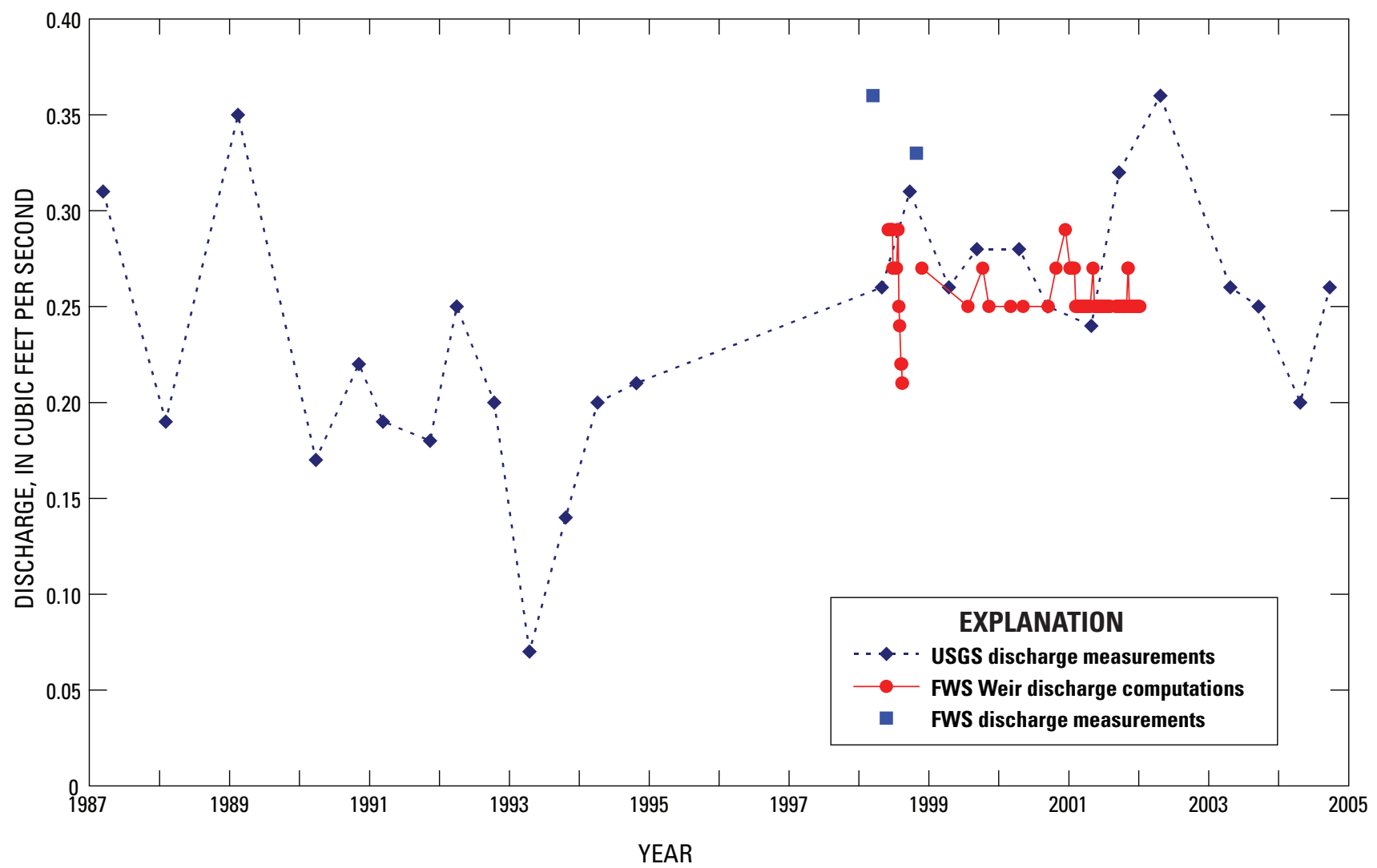

Figure B14. Periodic discharge measurements for partial-record stream-gaging station 364238114424201 Muddy River Springs (M-16) near Moapa, Nevada. Data from U.S. Geological Survey (USGS) National Water Information System (NWIS) database, accessed 2005, at http: //waterdata.usgs.gov, and U.S. Fish and Wildlife Service (FWS). 
Table B7. Periodic discharge measurements for partial-record stream-gaging station 364238114424201 Muddy River Springs 16 (M-16) near Moapa, Nevada, 1987-2004.

$\underline{\text { Table B7 }}$ data are available in an Excel data base for download at URL: $\underline{\text { http://pubs.water.usgs.gov/ofr2006-1311. }}$ 
Table B8. Periodic discharge measurements and weir discharge computations for partial-record stream-gaging station 364238114424201 Muddy River Springs 16 (M-16) near Moapa, Nevada, 1998-2002.

[Data from U.S. Fish and Wildlife Service]

$\underline{\text { Table B8 }}$ data are available in an Excel data base for download at URL: $\underline{\text { http://pubs.water.usgs.gov/ofr2006-1311. }}$ 

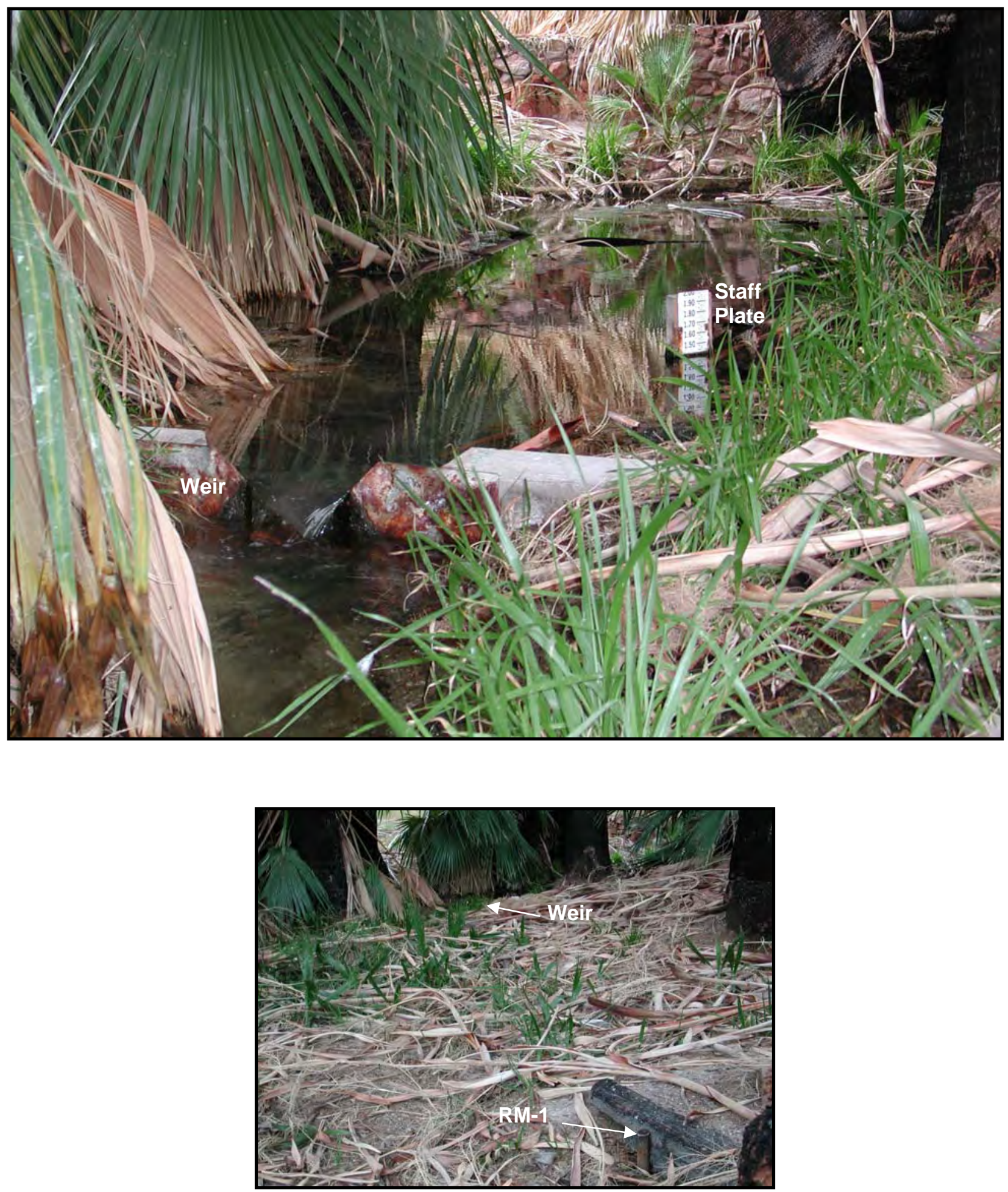

RM-1

(1,758.08 ft)

Figure B15. Location of U.S. Fish and Wildlife Service weir and staff plate, and reference mark (RM-1) at partial-record stream-gaging station 364238114424201 Muddy River Springs 16 (M-16) near Moapa, Nevada. Photographed June 10, 2004 by D. Beck. Elevation of RM-1 in feet above NAVD 88. 


\section{Muddy River Springs 20 (M-20) near Moapa, Nevada}

The partial-record gaging station at Muddy River Springs 20 (M-20) was established by the U.S. Geological Survey (USGS) on October 25, 1994, and is about $50 \mathrm{ft}$ upstream of the confluence of Plummer East with the Plummer Main tributary (fig. B9). Flow at Muddy River Springs 20 originates upstream of several springs that had been used to fill a large swimming pool previously operated by the former Desert Oasis Warm Springs Resort. The area is now part of the Moapa Valley National Wildlife Refuge. The U.S. Fish and Wildlife Service (FWS) has removed many of the resort's recreational facilities and currently is restoring the springs. Periodic discharge measurements have been made by the USGS since 1994. Discharge measurements for the period of record are plotted in figure B16 and listed in table B9.

Photograph of the staff plate established for the Muddy River Springs 20 monitoring station on June 10, 2004, is included in figure B17. On May 26, 2005, the large swimming pool upstream of the gage was observed to have been removed as part of the restoration program at the refuge. 


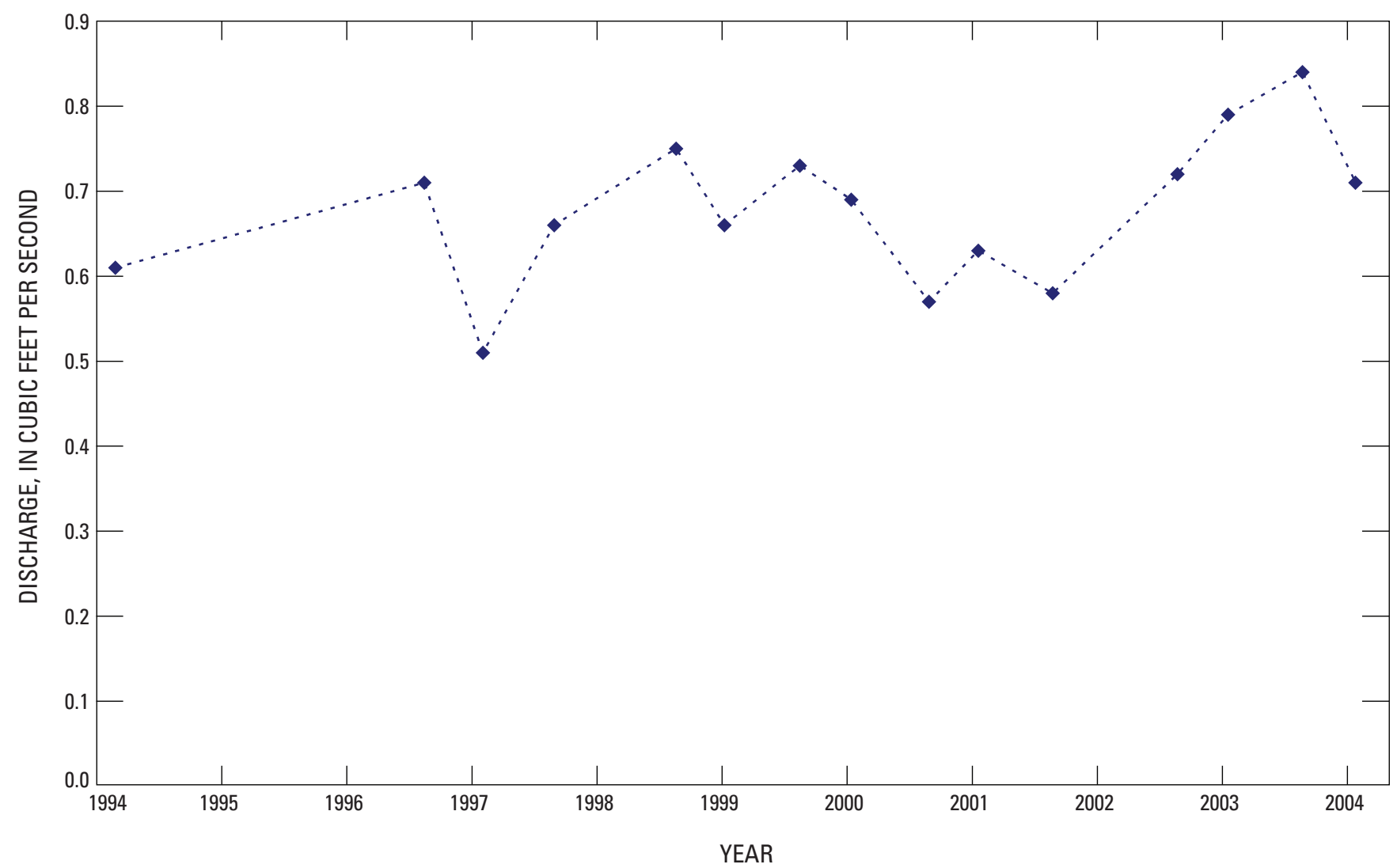

Figure B16. Periodic discharge measurements for partial-record stream-gaging station 364238114424301 Muddy River Springs 20 (M-20) near Moapa, Nevada, 1994-2004. Data from U.S. Geological Survey (USGS) National Water Information System (NWIS) data base, accessed 2005 at http://waterdata.usgs.gov 
Table B9. Periodic discharge measurement for partial-record stream-gaging station 364238114424301 Muddy River Springs 20 (M-20) near Moapa, Nevada, 1994-2004.

[Data from U.S. Geological Survey (USGS) National Water Information System (NWIS) data base, accessed 2005 at http://waterdata.usgs.gov]

Table B9 data are available in an Excel data base for download at URL: http://pubs.water.usgs.gov/ofr2006-1311. 

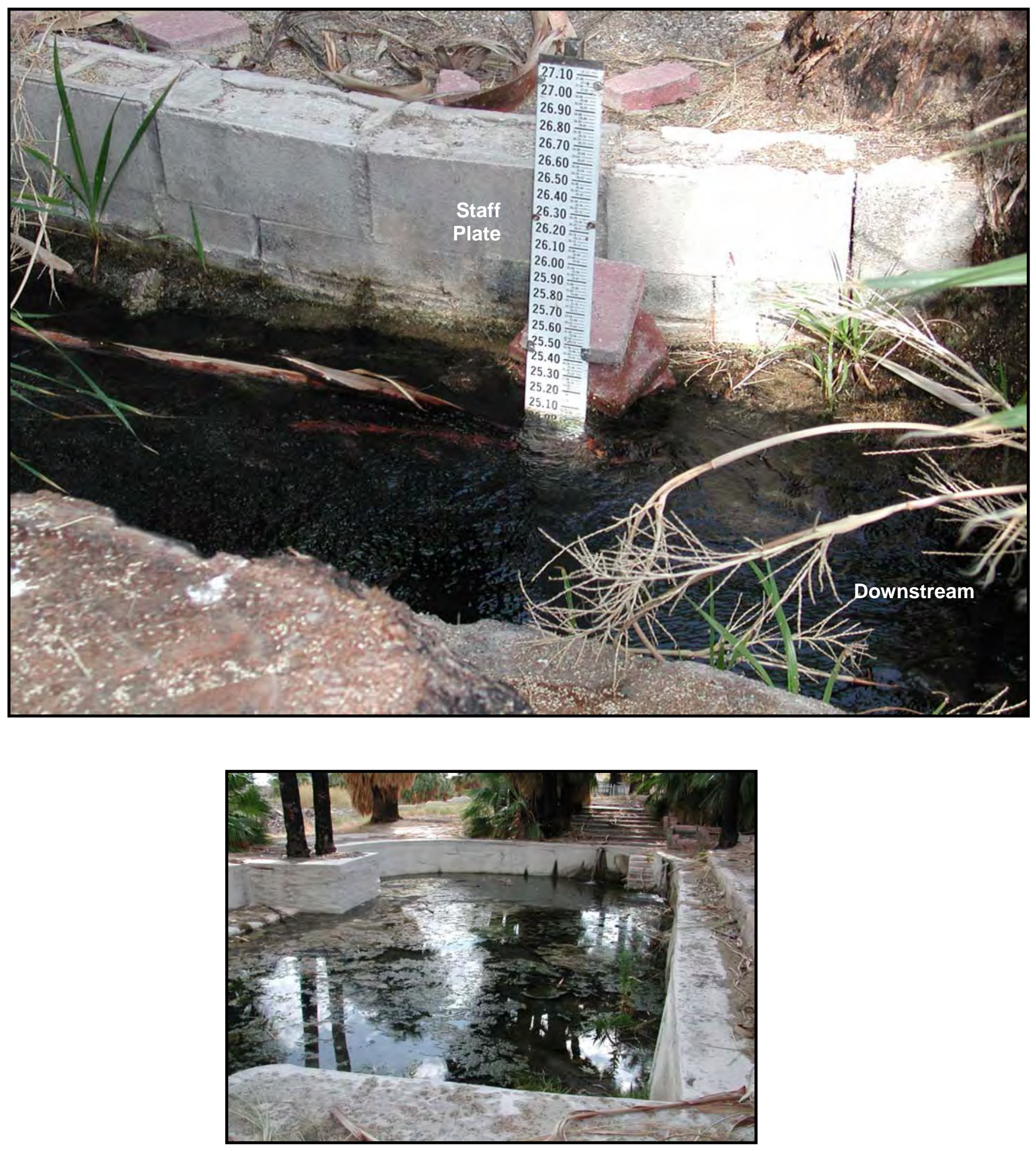

Swimming pool upstream of M-20

Figure B17. Location of the staff plate at partial-record stream-gaging station 364238114424301 Muddy River Springs 20 (M-20) near Moapa, Nevada, and view of the spring-fed swimming pool upstream of the gage. Photographed June 10, 2004 by D. Beck. 


\section{Miscellaneous Water-Quality Sites in the Plummer Springs Group near Moapa, Nevada}

Converse Consultants, on contract with Nevada Power Company, have been measuring water temperature and specific conductance at selected spring sites in the Warm Springs area since 1997. Eight springs were measured within the Plummer Springs Group on the Moapa Valley National Wildlife Refuge and were designated, by Converse Consultants (2004) as sites S1a, S1b, S34, S42, S43, S44, S44a, and S56. Sites S44 and S44a were tributary to Plummer West; sites S1a, S1b, S42, and S43 were tributary to Plummer Central; and sites S34 and S56 were tributary to Plummer East (fig. B9). Quarterly measurements have been made by Converse Consultants since April 1997. Water-temperature and specific-conductance measurements for the period of record are plotted in

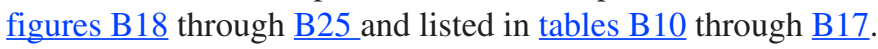

By December 2004, restoration work on the springs within the refuge had destroyed all the sampling sites listed above. As a result, Converse Consultants are now measuring water temperature and specific conductance at the U.S. Geological Survey partial-record stations at Muddy River Springs 15, 16, and 20 (fig. B9). 
Water-Surface Elevations, Discharge, and Water-Quality Data in the Warm Springs Area near Moapa, Nevada

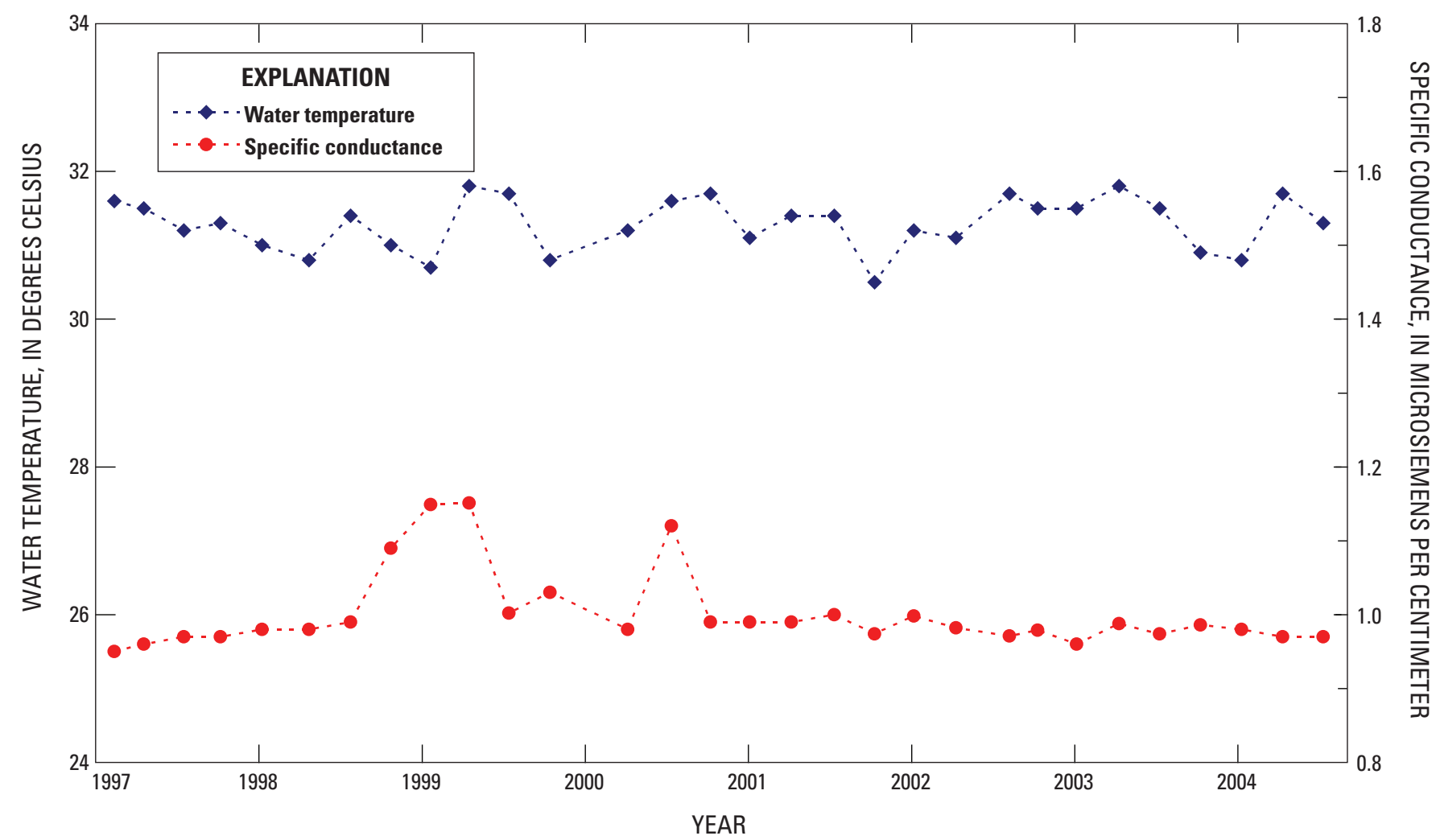

Figure B18. Water-temperature and specific-conductance measurements by Converse Consultants at site S1a in the Plummer Springs Group near Moapa, Nevada, 1997-2004. 


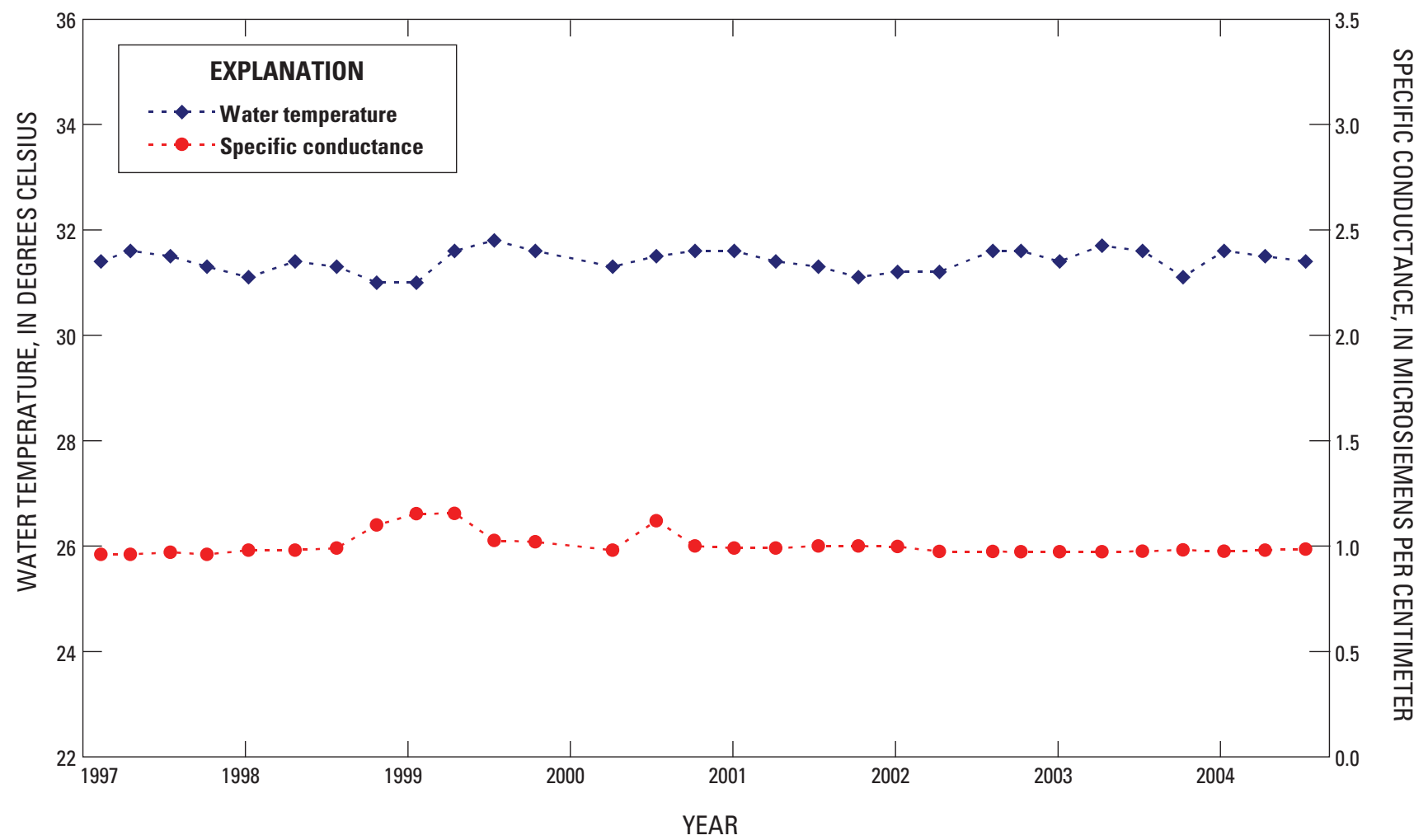

Figure B19. Water-temperature and specific-conductance measurements by Converse Consultants at site S1b in the Plummer Springs Group near Moapa, Nevada, 1997-2004. 
Water-Surface Elevations, Discharge, and Water-Quality Data in the Warm Springs Area near Moapa, Nevada

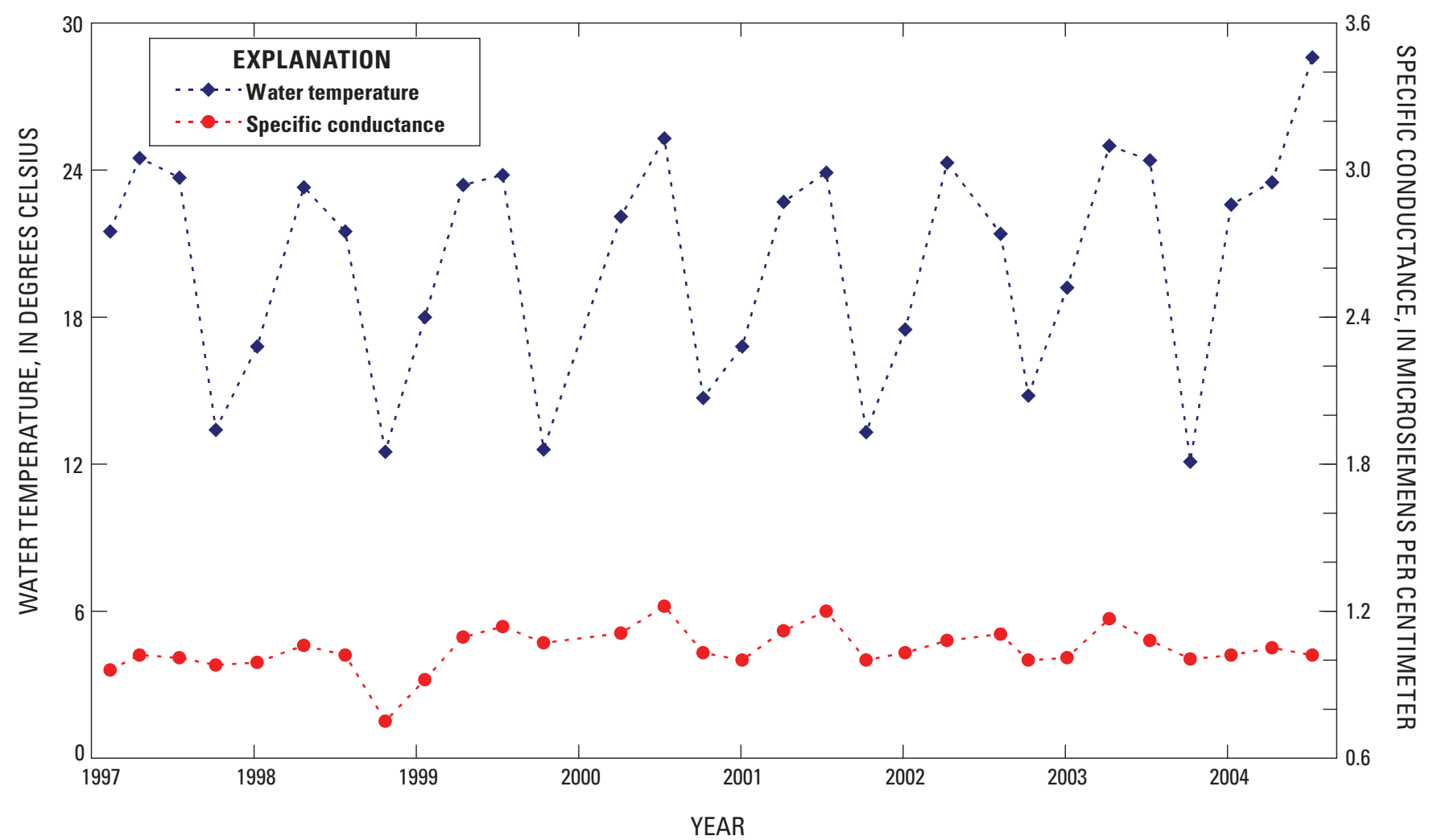

Figure B20. Water-temperature and specific-conductance measurements by Converse Consultants at site S34 in the Plummer Springs Group near Moapa, Nevada, 1997-2004. 


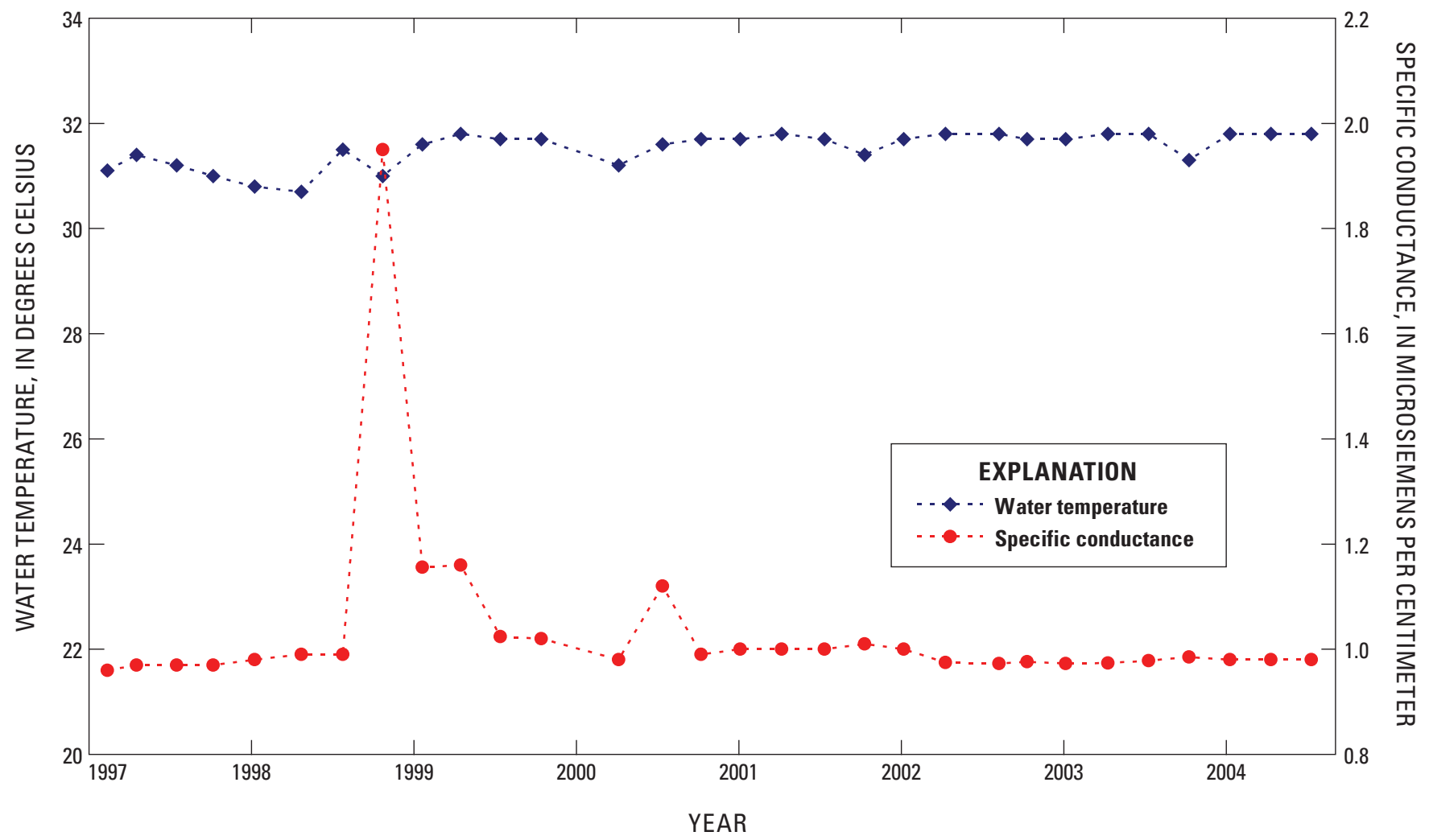

Figure B21. Water-temperature and specific-conductance measurements by Converse Consultants at site $\$ 42$ in the Plummer Springs Group near Moapa, Nevada, 1997-2004. 
Water-Surface Elevations, Discharge, and Water-Quality Data in the Warm Springs Area near Moapa, Nevada

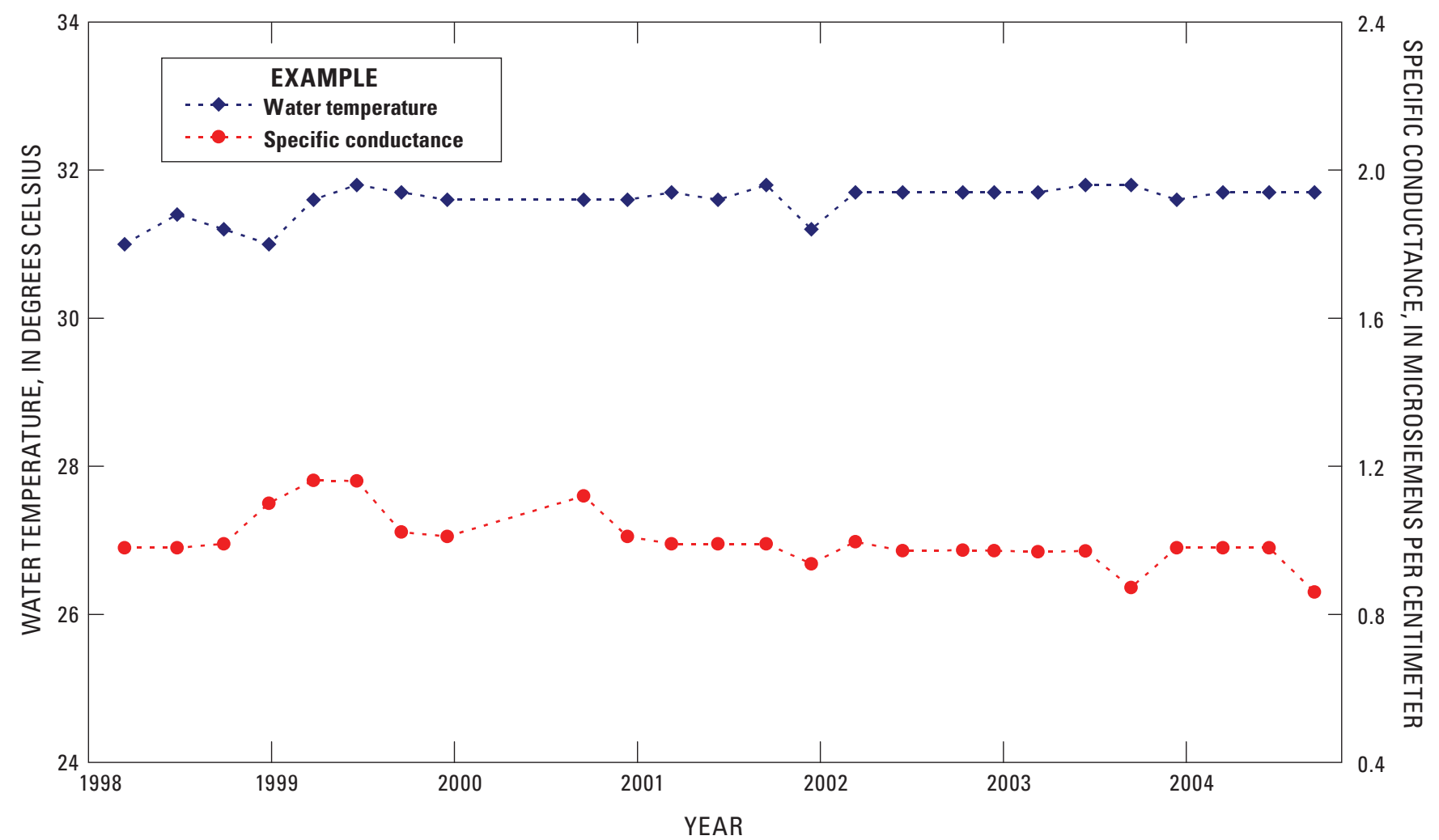

Figure B22. Water-temperature and specific-conductance measurements by Converse Consultants at site S43 in the Plummer Springs Group near Moapa, Nevada, 1997-2004. 


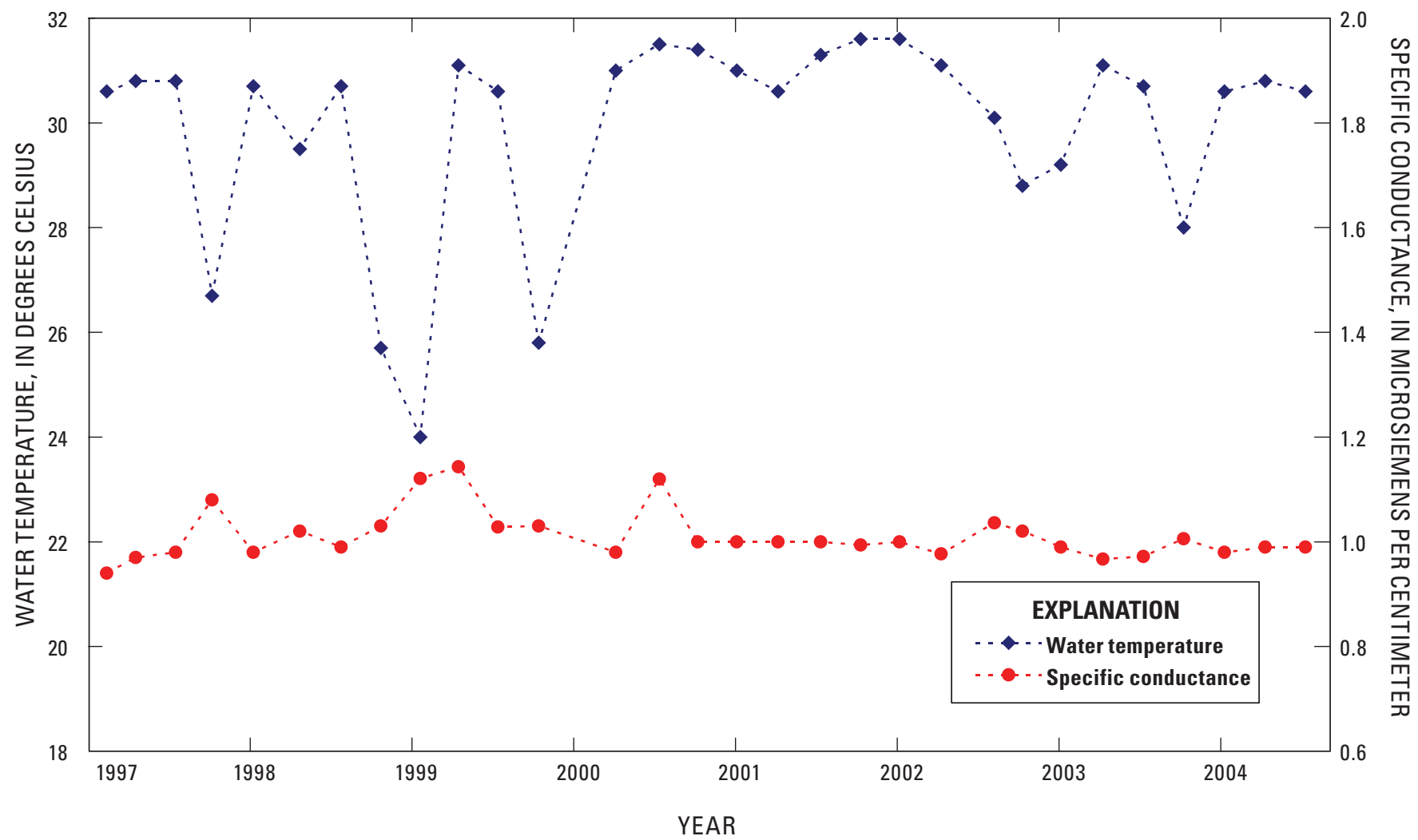

Figure B23. Water-temperature and specific-conductance measurements by Converse Consultants at site S44 in the Plummer Springs Group near Moapa, Nevada, 1997-2004. 
Water-Surface Elevations, Discharge, and Water-Quality Data in the Warm Springs Area near Moapa, Nevada

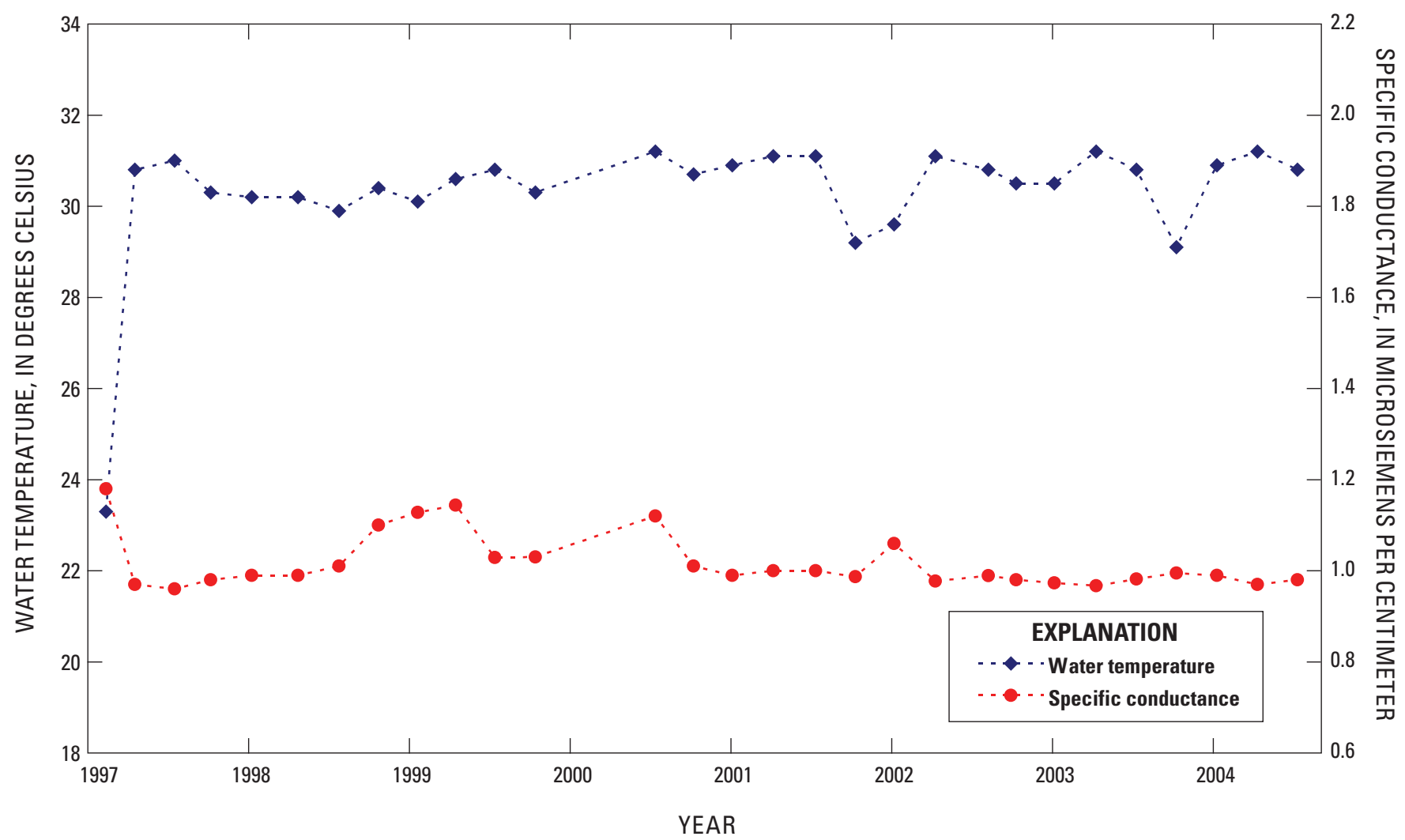

Figure B24. Water-temperature and specific-conductance measurements by Converse Consultants at site S44a in the Plummer Springs Group near Moapa, Nevada, 1997-2004. 


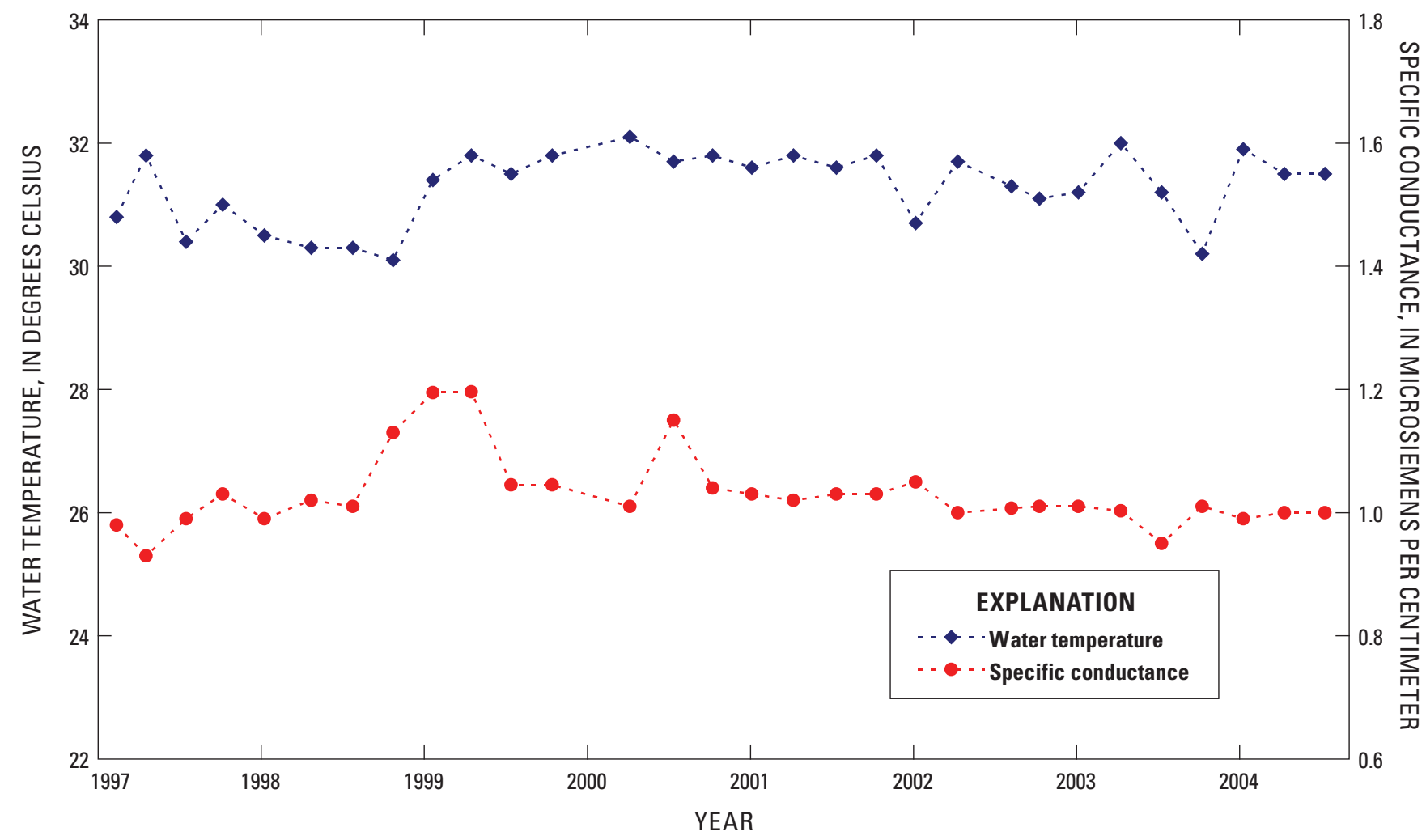

Figure B25. Water-temperature and specific-conductance measurements by Converse Consultants at site S56 in the Plummer Springs Group near Moapa, Nevada, 1997-2004. 
Table B10. Water-temperature and specific-conductance measurements by Converse Consultants at site S1a in the Plummer Springs Group near Moapa, Nevada, 1997-2004.

$\underline{\text { Table B10 }}$ data are available in an Excel data base for download at URL: $\underline{\text { http://pubs.water.usgs.gov/ofr2006-1311. }}$ 
Table B11. Water-temperature and specific-conductance measurements by Converse Consultants at site S1b in the Plummer Springs Group near Moapa, Nevada, 1997-2004.

$\underline{\text { Table B11 data are available in an Excel data base for download at URL: http://pubs.water.usgs.gov/ofr2006-1311. }}$ 
Table B12. Water-temperature and specific-conductance measurements by Converse Consultants at site S34 in the Plummer Springs Group near Moapa, Nevada, 1997-2004.

Table B12 data are available in an Excel data base for download at URL: http://pubs.water.usgs.gov/ofr2006-1311. 
Table B13. Water-temperature and specific-conductance measurements by Converse Consultants at site S42 in the Plummer Springs Group near Moapa, Nevada, 1997-2004.

$\underline{\text { Table B13 }}$ data are available in an Excel data base for download at URL: http://pubs.water.usgs.gov/ofr2006-1311. 
Table B14. Water-temperature and specific-conductance measurements by Converse Consultants at site S43 in the Plummer Springs Group near Moapa, Nevada, 1997-2004.

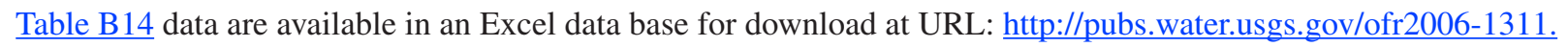


Table B15. Water-temperature and specific-conductance measurements by Converse Consultants at site S44 in the Plummer Springs Group near Moapa, Nevada, 1997-2004.

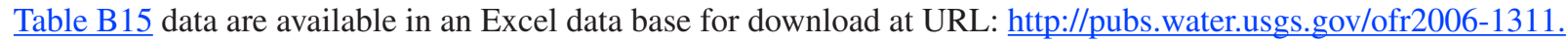


Table B16. Water-temperature and specific-conductance measurements by Converse Consultants at site S44a in the Plummer Springs Group near Moapa, Nevada, 1997-2004.

$\underline{\text { Table B16 }}$ data are available in an Excel data base for download at URL: http://pubs.water.usgs.gov/ofr2006-1311. 
Table B17. Water-temperature and specific-conductance measurements by Converse Consultants at site S56 in the Plummer Springs Group near Moapa, Nevada, 1997-2004.

Table B17 data are available in an Excel data base for download at URL: http://pubs.water.usgs.gov/ofr2006-1311. 
This page left intentionally blank. 


\section{Pederson Springs Group}

The following sites are included within this section:

09415908 Pederson East Spring near Moapa, Nevada (2002-04)

09415910 Pederson Spring near Moapa, Nevada (1987-2004)

364235114425201 Muddy River Springs 11 (M-11) near Moapa, Nevada (1987-2004)

364237114425401 Muddy River Springs 12 (M-12) near Moapa, Nevada (1987-2004)

364236114425401 Muddy River Springs 13 (M-13) near Moapa, Nevada (1986-2004)

364235114425301 Muddy River Springs 19 (M-19) near Moapa, Nevada (1998-2004)

09415920 Warm Springs West near Moapa, Nevada (1967-2005) 


\section{Pederson East Spring near Moapa, Nevada}

A continuous-record stream-gaging station was established by the U.S. Geological Survey (USGS) on Pederson East Spring on May 9, 2002. The hydraulic control is a 90-degree v-notch weir that was installed by the U.S. Fish and Wildlife Service in collaboration with the Southern Nevada Water Authority and the U.S. Bureau of Reclamation. Pederson East Spring is about $100 \mathrm{ft}$ north of the Moapa Valley National Wildlife Refuge service road (fig. B26) and is part of a cluster of springs that drain to the northeast. Flow from Pederson East Spring joins with discharge from Pederson Spring about $200 \mathrm{ft}$ downstream from the gage.
Daily mean discharges for the period of record are plotted on figure B27 and listed in table B18. Photographs of the gage and weir, and selected reference marks established for this gage on June 9, 2004, are shown in figure B28.

Water samples were collected at this site on January 12, and May 18, 2004, by the Desert Research Institute (DRI) and analyzed for major ions and stable hydrogen and oxygen isotopes. The results of the analyses are shown in table B19. 


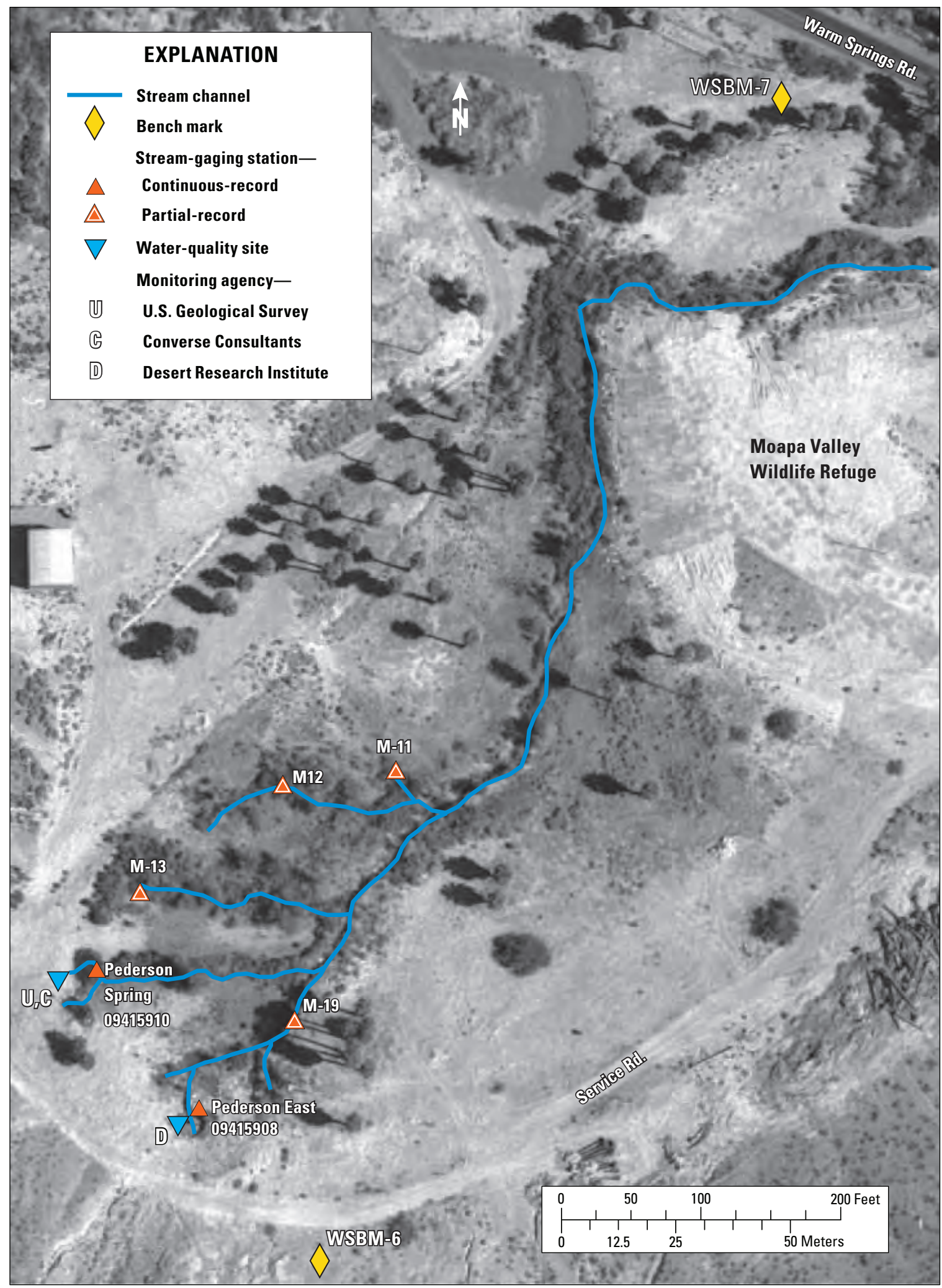

Figure B26. Location of Pederson Springs Group monitoring sites and bench marks WSBM-6 and WSBM-7 in the Warm Springs area near Moapa, Nevada. 
Water-Surface Elevations, Discharge, and Water-Quality Data in the Warm Springs Area near Moapa, Nevada

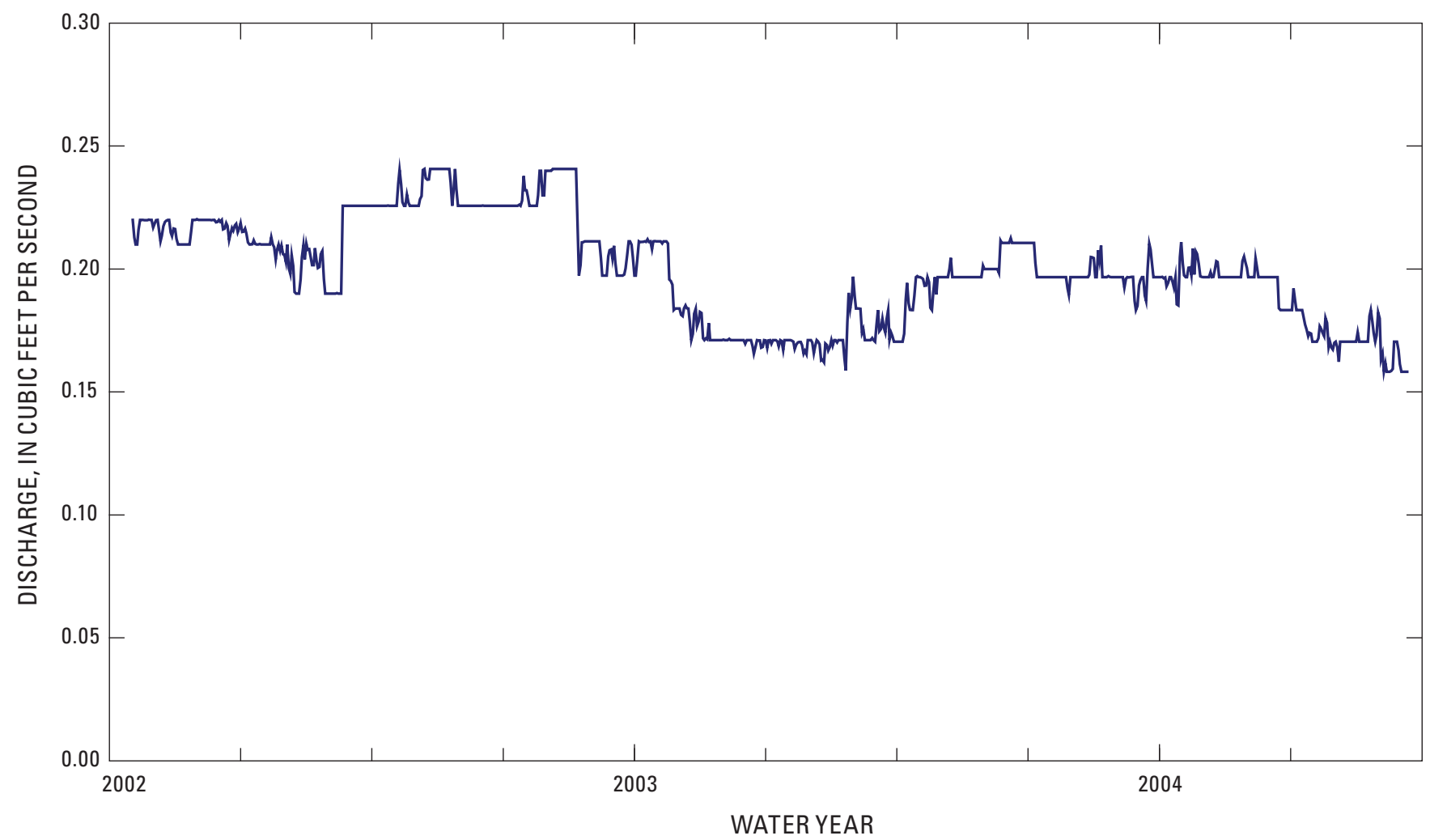

Figure B27. Daily mean discharges for continuous-record stream-gaging station 09415908 Pederson East Spring near Moapa, Nevada, water years 2002-04. 
Table B18. Daily mean discharges for continuous-record stream-gaging station 09415908 Pederson East Spring near Moapa, Nevada, water years 2002-04.

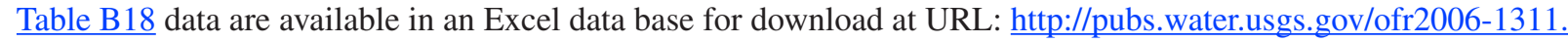




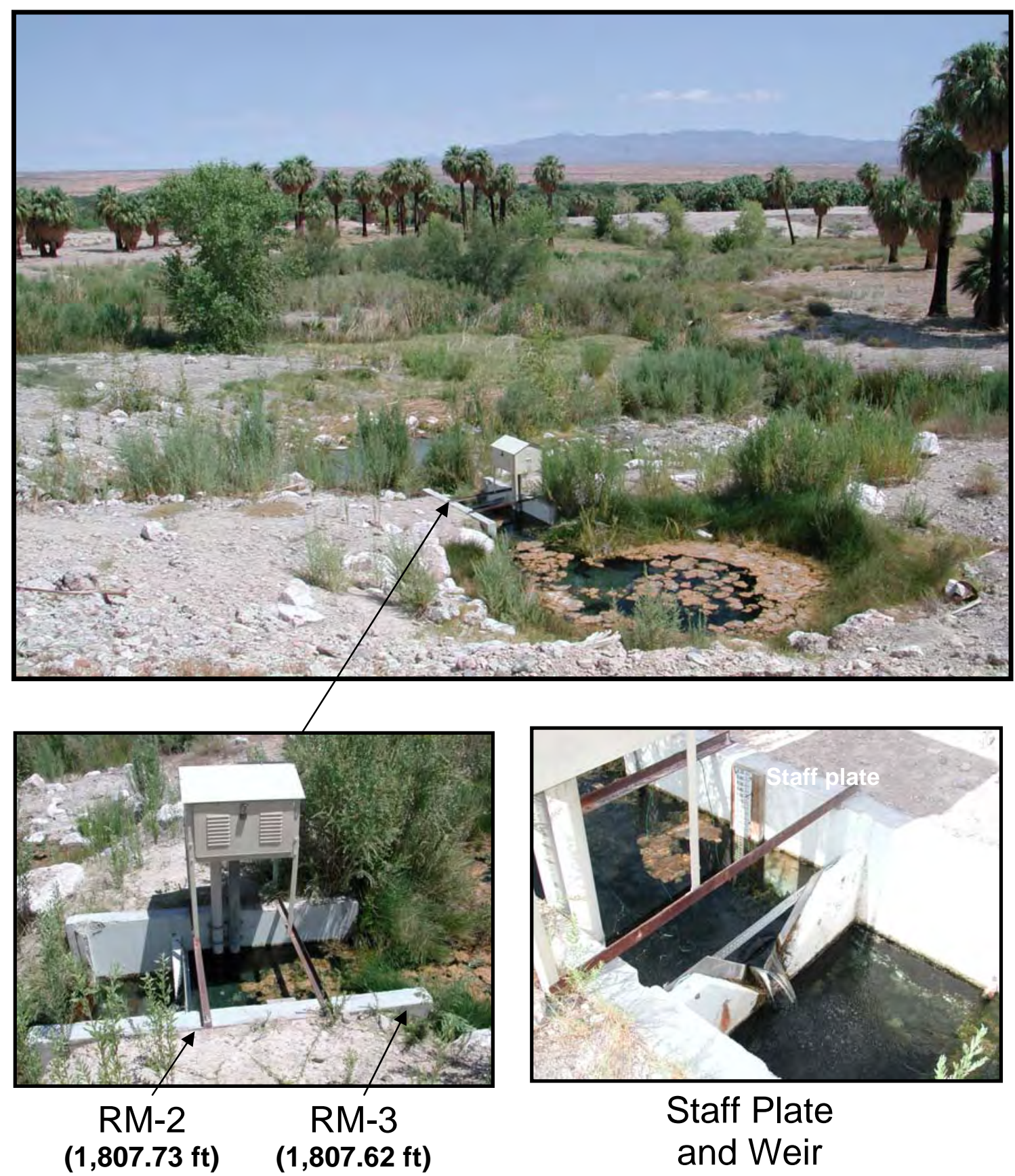

Figure B28. Location of staff plate and selected reference marks (RM) for station 09415908 Pederson East Spring in the Moapa Valley National Wildlife Refuge near Moapa, Nevada. Photographed June 9, 2004 by D. Beck. Elevation in feet above NAVD 88. 
Table B19. Water-quality data collected by Desert Research Institute at continous-record stream-gaging station 09415908 Pederson East Spring near Moapa, Nevada, January 12 and May 18, 2004.

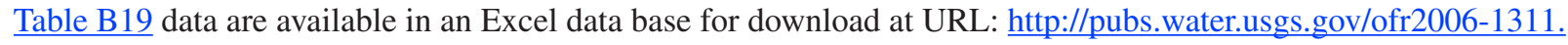




\section{Pederson Spring near Moapa, Nevada}

A continuous-record stream-gaging station with 45 degree v-notch aluminum weir was established by the U.S. Geological Survey (USGS) on Pederson Spring on October 1, 1986. Pederson Spring is about $50 \mathrm{ft}$ northeast of the Moapa Valley National Wildlife Refuge service road (fig. B26) and is part of a cluster of springs that drains to the northeast. Flow from Pederson Spring joins with discharge from Pederson East Spring about $250 \mathrm{ft}$ downstream from the gage. Reclamation of the spring and an adjacent area by the U.S. Fish and Wildlife Service began in 2002; a new weir, with 45 degree v-notch, was installed on April 27, 2004 (fig. B29). The new weir was installed because water was leaking around the old weir and the gage was not measuring the flows accurately.
Daily mean discharges for the period of record are plotted on figure B30 and listed in table B20. Photographs of the gage and weir and of selected reference marks established for this gage on June 9, 2004, are shown in figure B31.

Water-quality data are available for this site from Converse Consultants and the USGS. Beginning April 22, 1997, Converse Consultants began quarterly water temperature and specific conductance measurements. Data collected from 1997 through December 2004 are plotted on figure B32 and listed in table B21.

Water samples were collected by the USGS on July 30, 2003, as part of the National Water-Quality Assessment Program. An extensive suite of analyses were made, and the results are listed in table B22. 


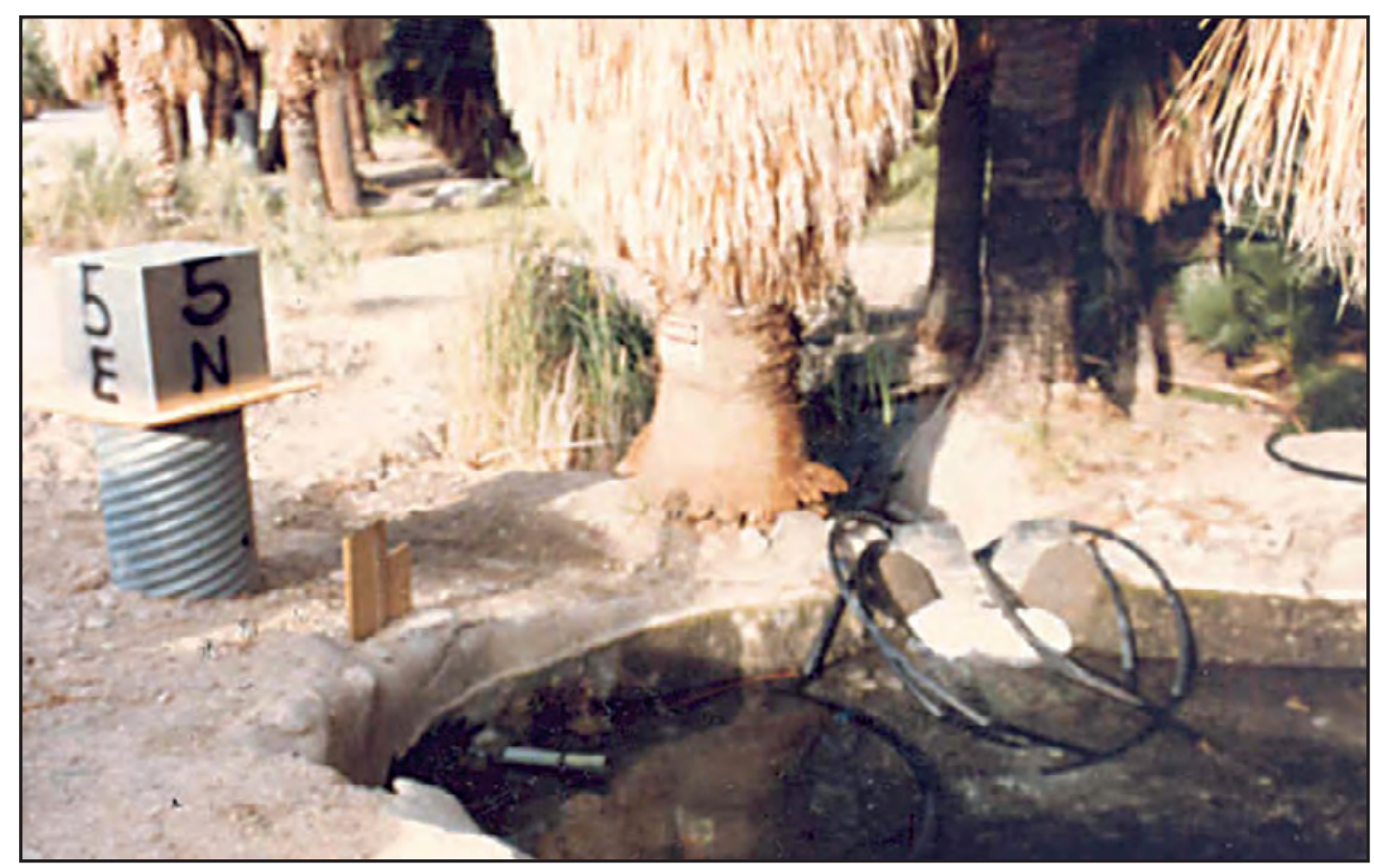

\section{A. View of first weir being installed in 1986.}

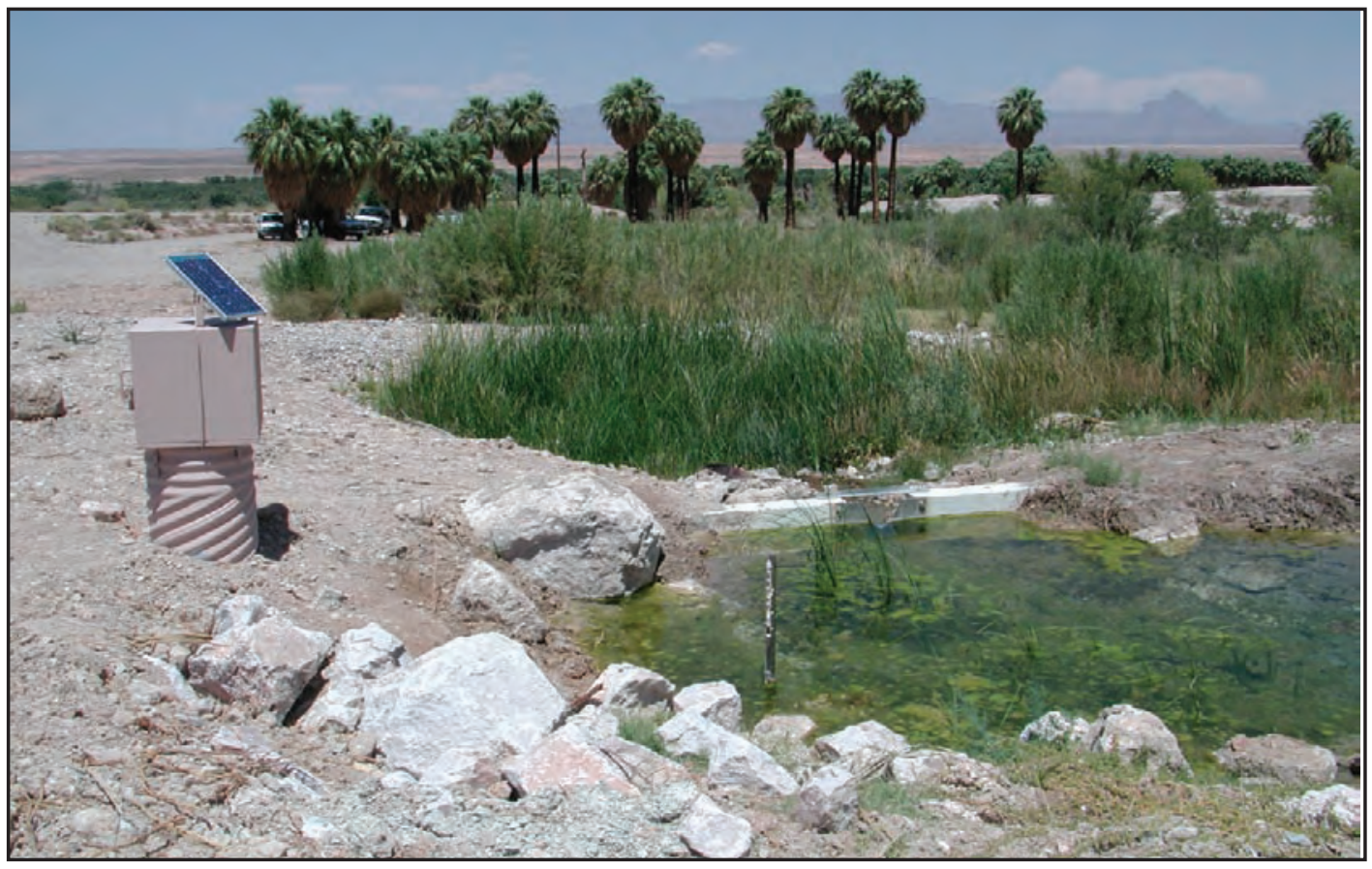

\section{B. View of new weir installed in 2004.}

Figure B29. Looking downstream at continuous-record stream-gaging station 09415910 Pederson Spring near Moapa, Nevada. 
Water-Surface Elevations, Discharge, and Water-Quality Data in the Warm Springs Area near Moapa, Nevada

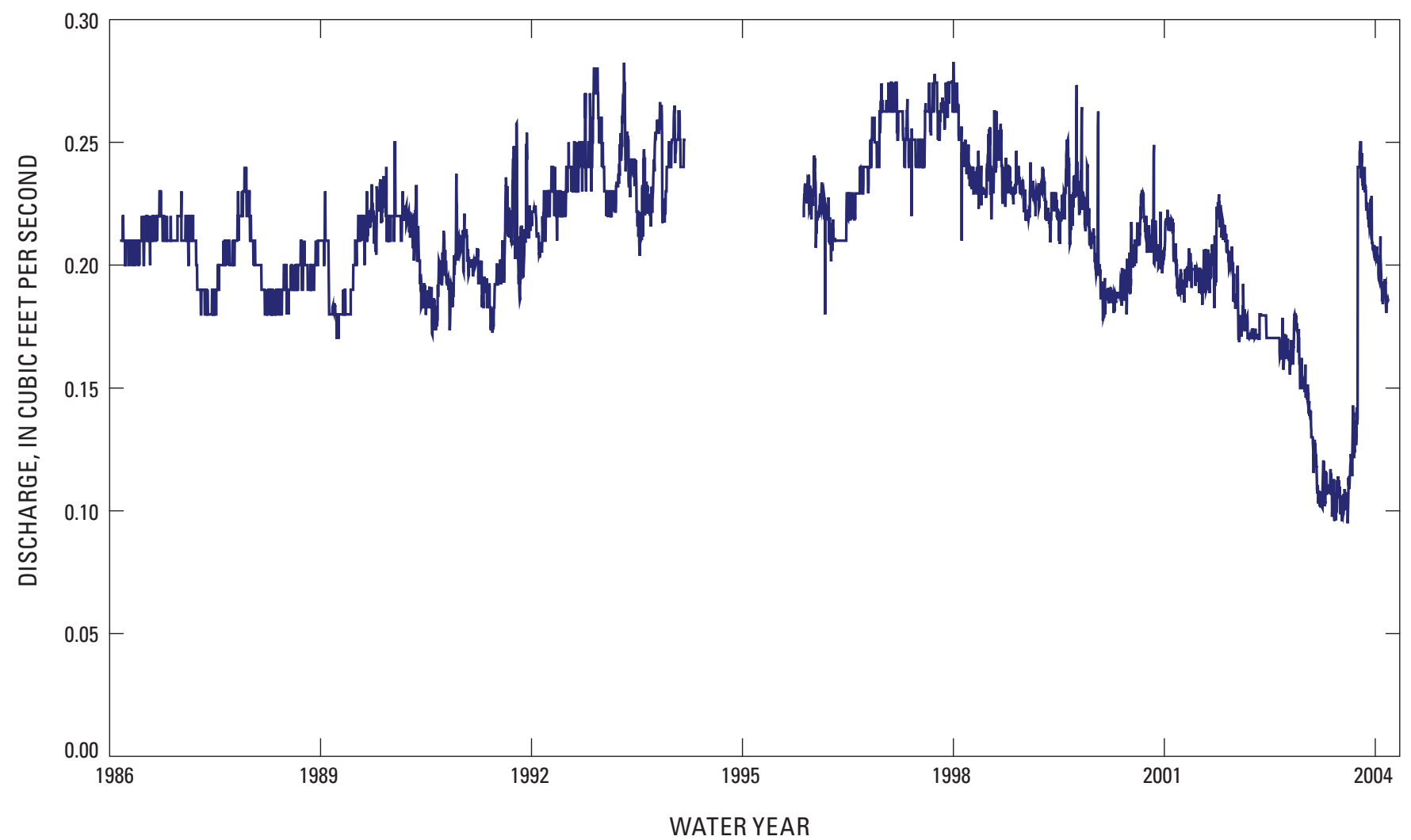

Figure B30. Daily mean discharges for continuous-record stream-gaging station 09415910 Pederson Spring near Moapa, Nevada, water years 1987-2004. 
Table B20. Daily mean discharges for continuous-record stream-gaging station 09415910 Pederson Spring near Moapa, Nevada, water years 1987-2004.

Table B20 data are available in an Excel data base for download at URL: http://pubs. water.usgs.gov/ofr2006-1311. 


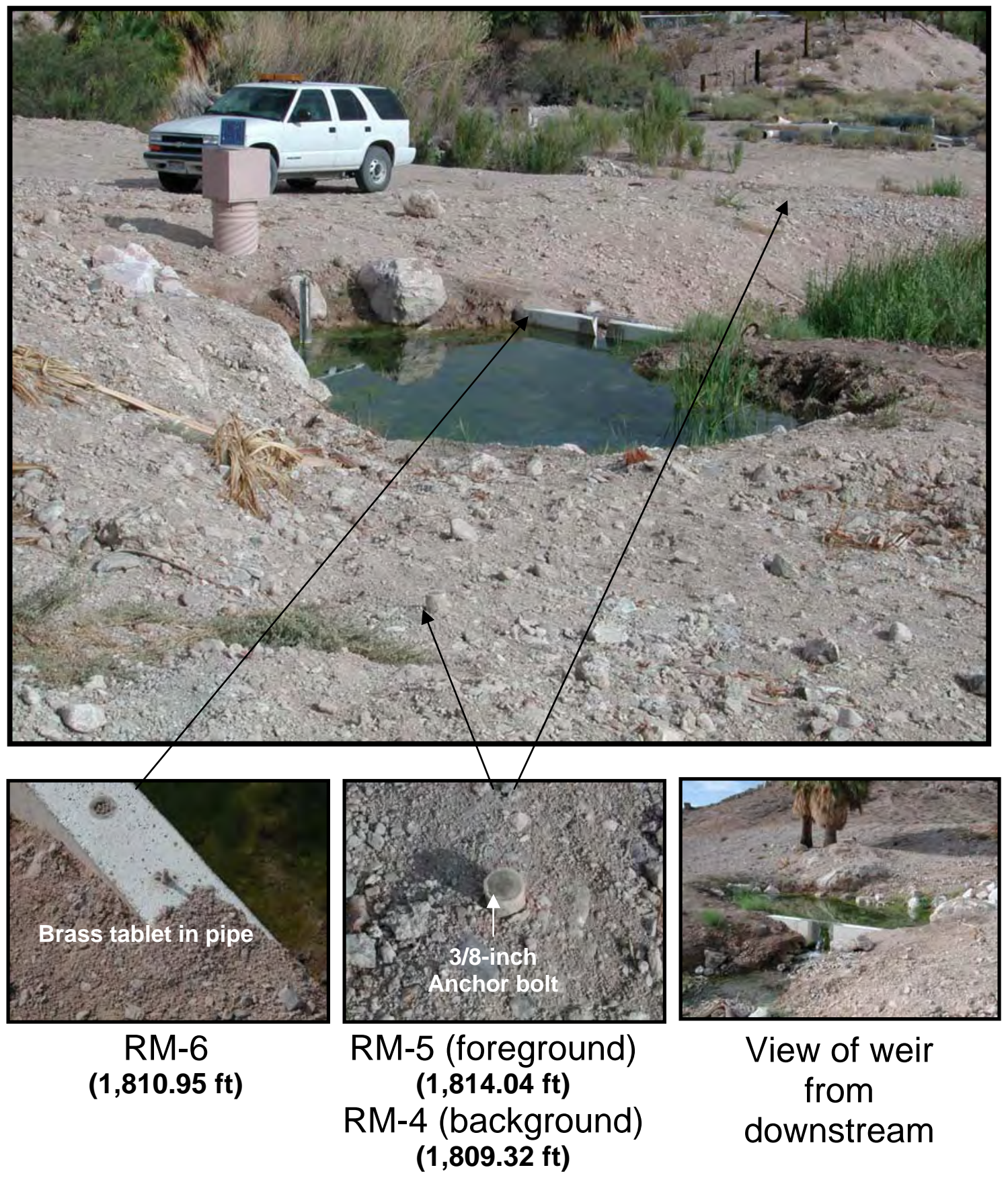

Figure B31. Location of selected reference marks (RM) at continuous-record stream-gaging station 09415910 Pederson Spring in the Moapa Valley National Wildlife Refuge near Moapa, Nevada. Photographed June 9, 2004 by D. Beck. Elevation in feet above NAVD 88. 


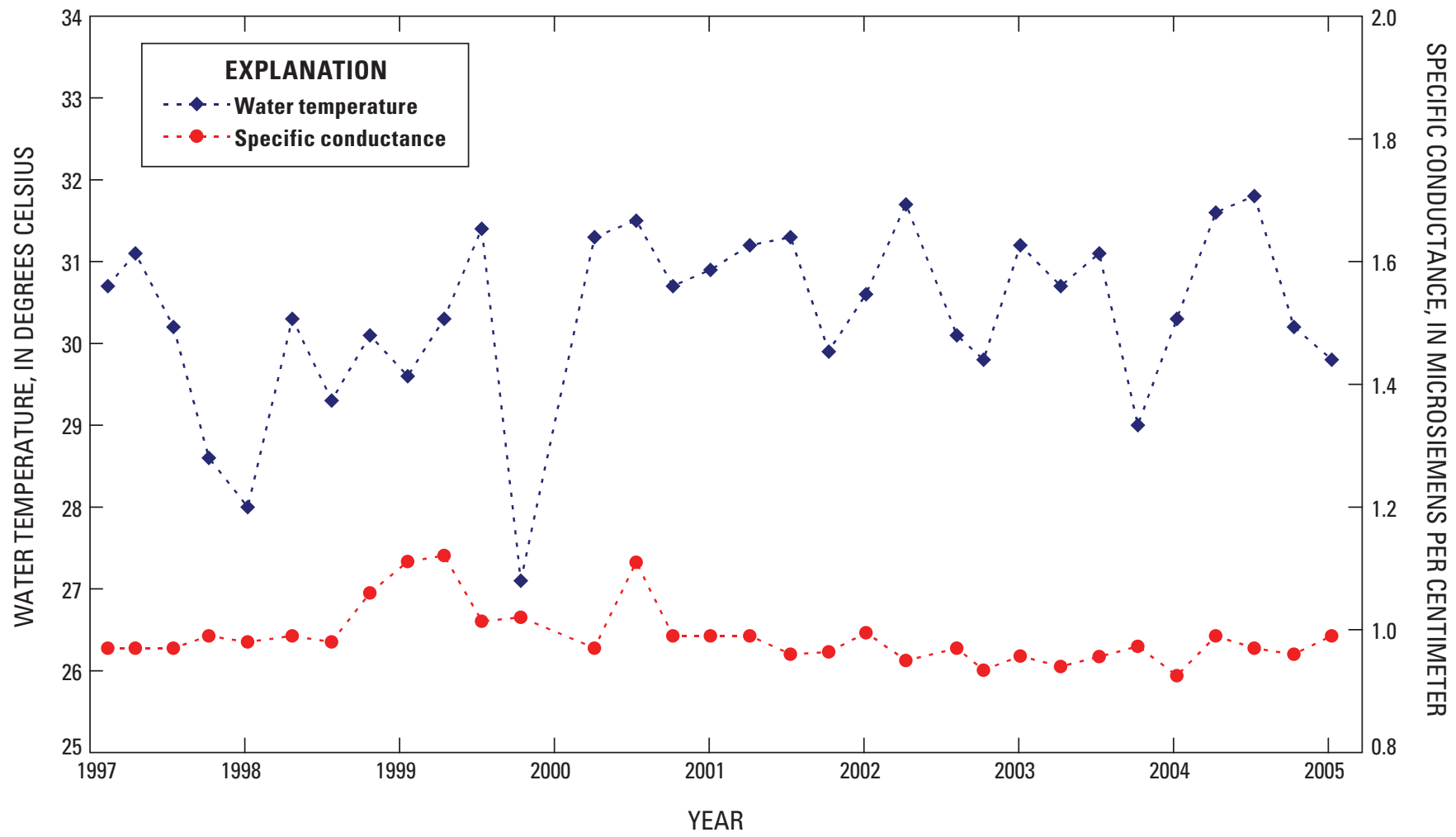

Figure B32. Water-temperature and specific-conductance measurements by Converse Consultants for station 09415910 Pederson Spring near Moapa, Nevada, 1997-2005. 
Table B21. Water-temperature and specific-conductance measurements by Converse Consultants at station 09415910 Pederson Spring near Moapa, Nevada, 1997-2005.

Table B21 data are available in an Excel data base for download at URL: http://pubs.water.usgs.gov/ofr2006-1311. 
Table B22. Water-quality data collected for continuous-record stream-gaging station 09415910 Pederson Spring near Moapa, Nevada, July 30, 2003.

Table B22 data are available in an Excel data base for download at URL: http://pubs.water.usgs.gov/ofr2006-1311. 


\section{Muddy River Springs 11 (M-11) near Moapa, Nevada}

The partial-record stream-gaging station at Muddy River Springs 11 (M-11) was established by the U.S. Geological Survey (USGS) on March 12, 1987, and is about $50 \mathrm{ft}$ upstream of the main channel that drains the combined flow of Pederson and Pederson East spring tributaries (fig. B26). Discharge at Muddy River Springs 11 originates about 20 ft upstream and is part of a cluster of springs known as the Pederson Spring Group that drains to the northeast.
Periodic discharge measurements have been made by the USGS since March 1987. Discharge measurements for the period of record are plotted in figure B33 and listed in table B23. Photographs of the staff plate and a selected reference mark established for the Muddy River Springs 11 monitoring site on June 9, 2004, are included in figure B34. 


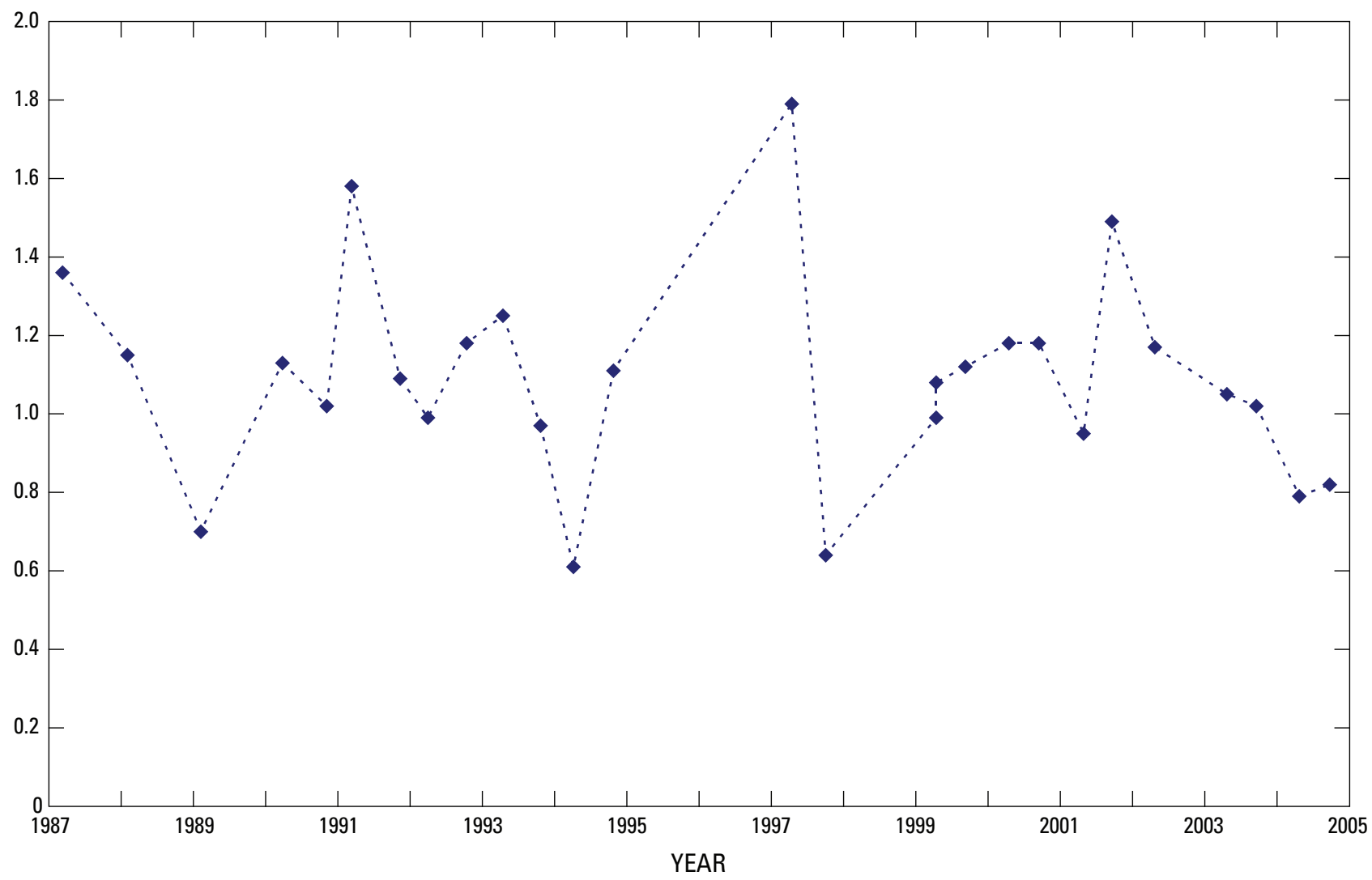

Figure B33. Periodic discharge measurements for partial-record stream-gaging station 364235114425201 Muddy River Springs 11 (M-11) near Moapa, Nevada, 1987-2004. 
Table B23. Periodic discharge measurements for partial-record stream-gaging station 364235114425201 Muddy River Sprngs 11 (M-11) near Moapa, Nevada, 1987-2004.

Table B23 data are available in an Excel data base for download at URL: http://pubs.water.usgs.gov/ofr2006-1311. 


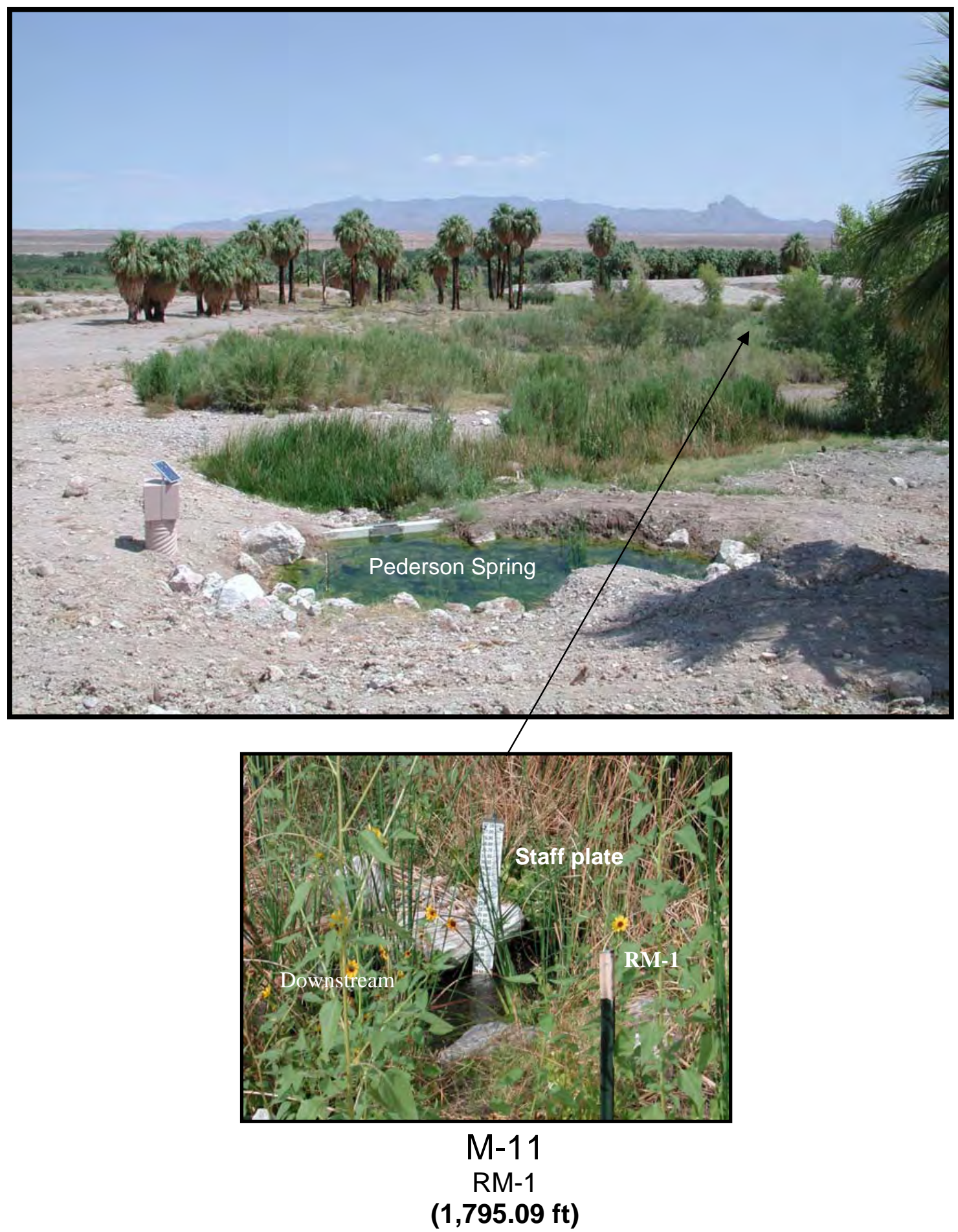

Figure B34. Location of staff plate and reference mark (RM-1) for partial-record stream-gaging station Muddy River Springs 11 (M-11) in the Moapa Valley National Wildlife Refuge near Moapa, Nevada. Photographed June 9, 2004 by D. Beck. Elevation in feet NAVD 88. 


\section{Muddy River Springs 12 (M-12) near Moapa, Nevada}

The partial-record stream-gaging station at Muddy River Springs 12 was established by the U.S. Geological Survey (USGS) on March 12, 1987, and is about $150 \mathrm{ft}$ upstream of the confluence with the main channel that drains the combined flows from Pederson and Pederson East Spring tributaries (fig. B26). Flow at Muddy River Springs 12 originates approximately $10 \mathrm{ft}$ upstream and is part of a cluster of springs known as the Pederson Spring Group that drains to the northeast.
Periodic discharge measurements have been made by the USGS since March 1987. Discharge measurements for the period of record are plotted in figure B35 and listed in table B24. Photographs of the staff plate and a selected reference mark established for the Muddy River Springs 12 monitoring site on June 9, 2004, are included in figure B36. 


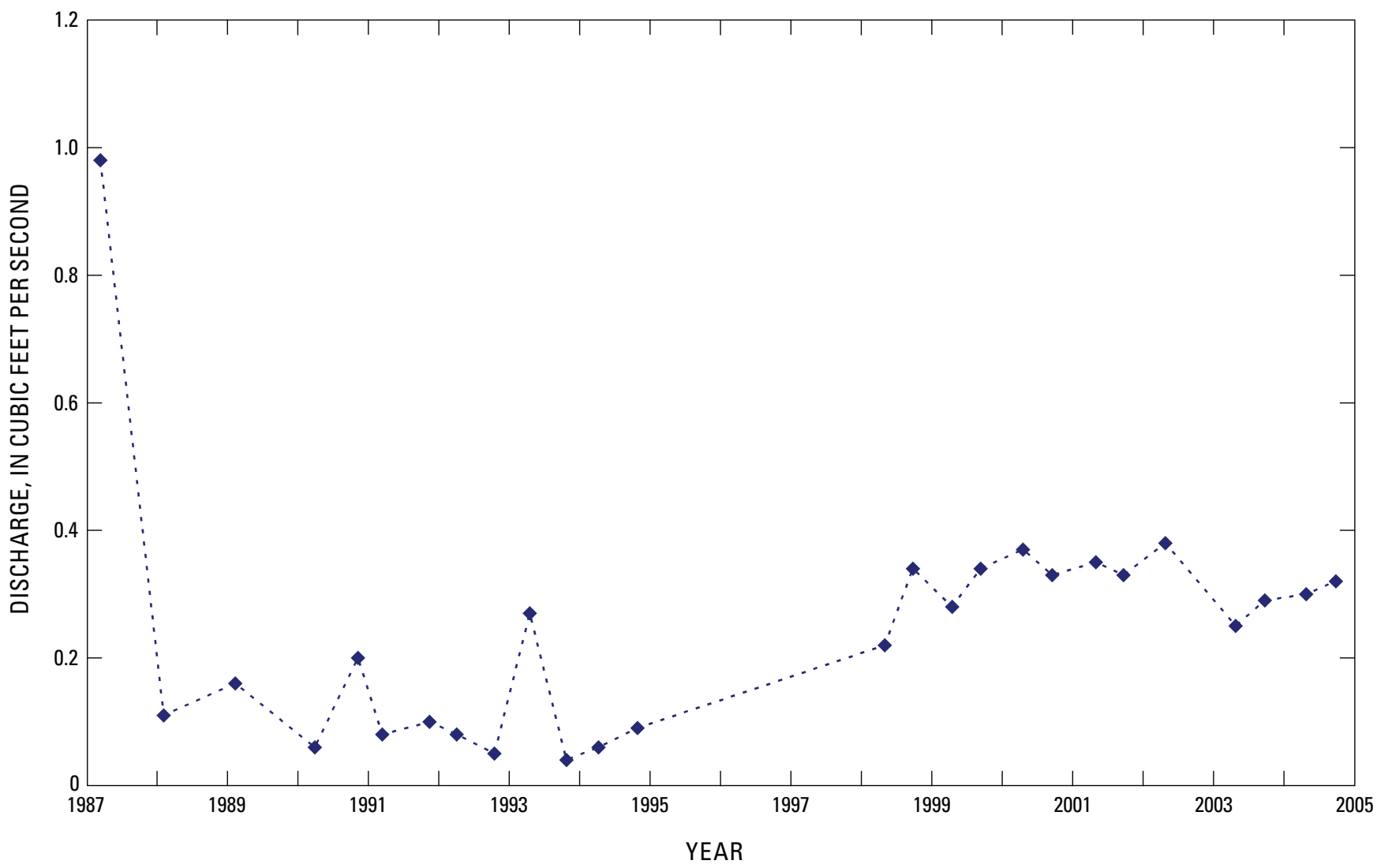

Figure B35. Periodic discharge measurements for partial-record stream-gaging station 364237114425401 Muddy River Springs 12 (M-12) near Moapa, Nevada, 1987-2004. 
Table B24. Periodic discharge measurements for partial-record stream-gaging station 364237114425401 Muddy River Springs 12 (M-12) near Moapa, Nevada, 1987-2004.

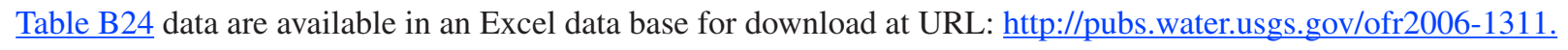




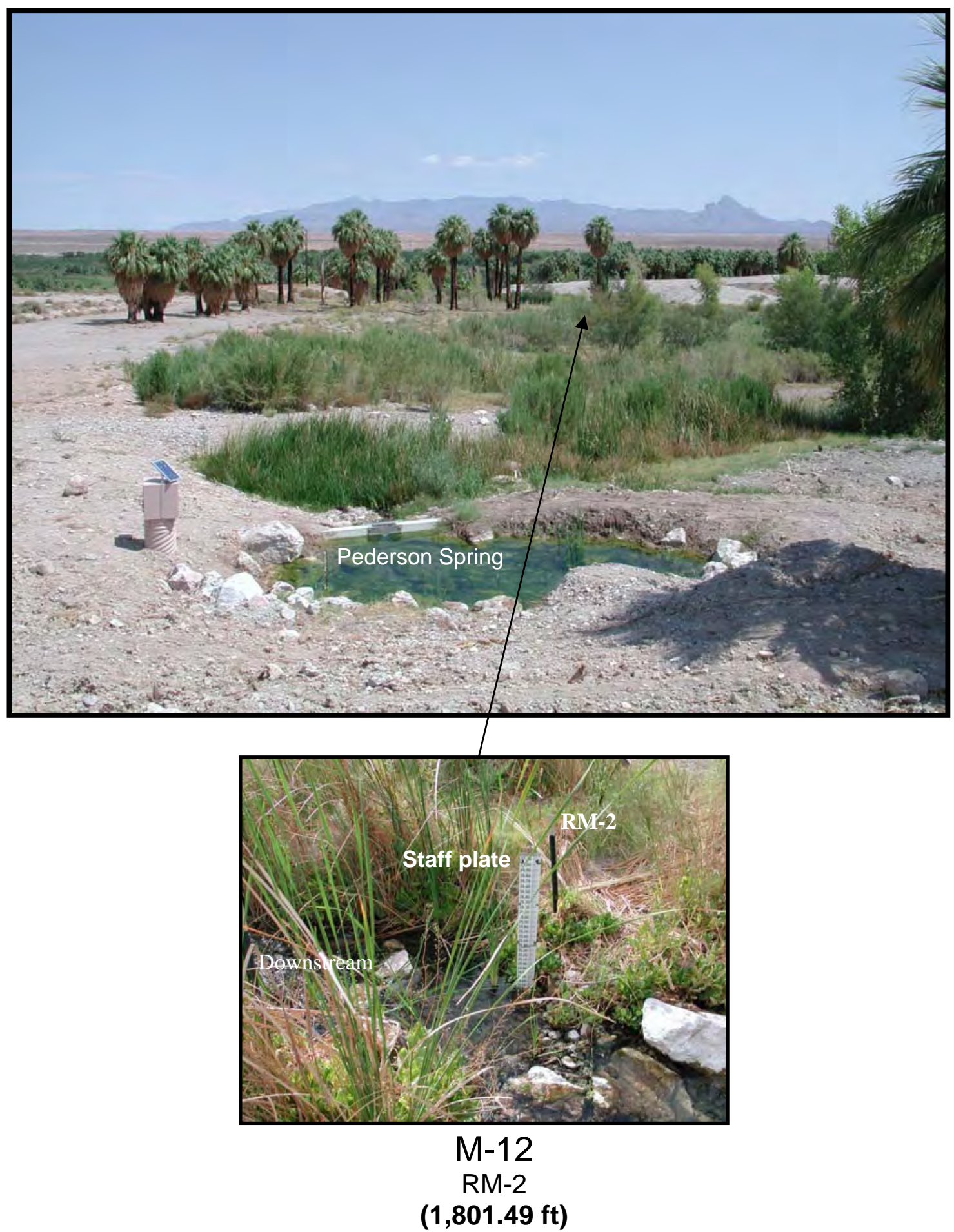

Figure B36. Location of staff plate and reference mark (RM-2) for partial-record stream-gaging station Muddy River Springs 12 (M-12) in the Moapa Valley National Wildlife Refuge near Moapa, Nevada. Photographed June 9, 2004 by D. Beck. Elevation in feet above NAVD 88. 


\section{Muddy River Springs 13 (M-13) near Moapa, Nevada}

The partial-record stream-gaging station at Muddy River Springs 13 was established by the U.S. Geological Survey (USGS) on January 28, 1986, and is about $150 \mathrm{ft}$ upstream of the confluence with the main channel that drains the combined flows from Pederson and Pederson East Spring tributaries (fig. B26). Flow at Muddy River Springs 13 originates approximately $25 \mathrm{ft}$ upstream and is part of a cluster of springs known as the Pederson Spring Group that drains to the northeast.
Periodic discharge measurements have been made by the USGS since January 1986. Discharge measurements for the period of record are plotted in figure B37 and listed in table B25. Photographs of the staff plate and a selected reference mark established for the Muddy River Springs 13 monitoring site on June 9, 2004, are included in figure B38.

Water samples were collected at this site on January 12 and May 18, 2004, by Desert Research Institute (DRI) and analyzed for major ions, physical and chemical parameters (dissolved oxygen, $\mathrm{pH}$, and water temperature), and stable hydrogen and oxygen isotopes. The results of the analyses are shown in table B26. 


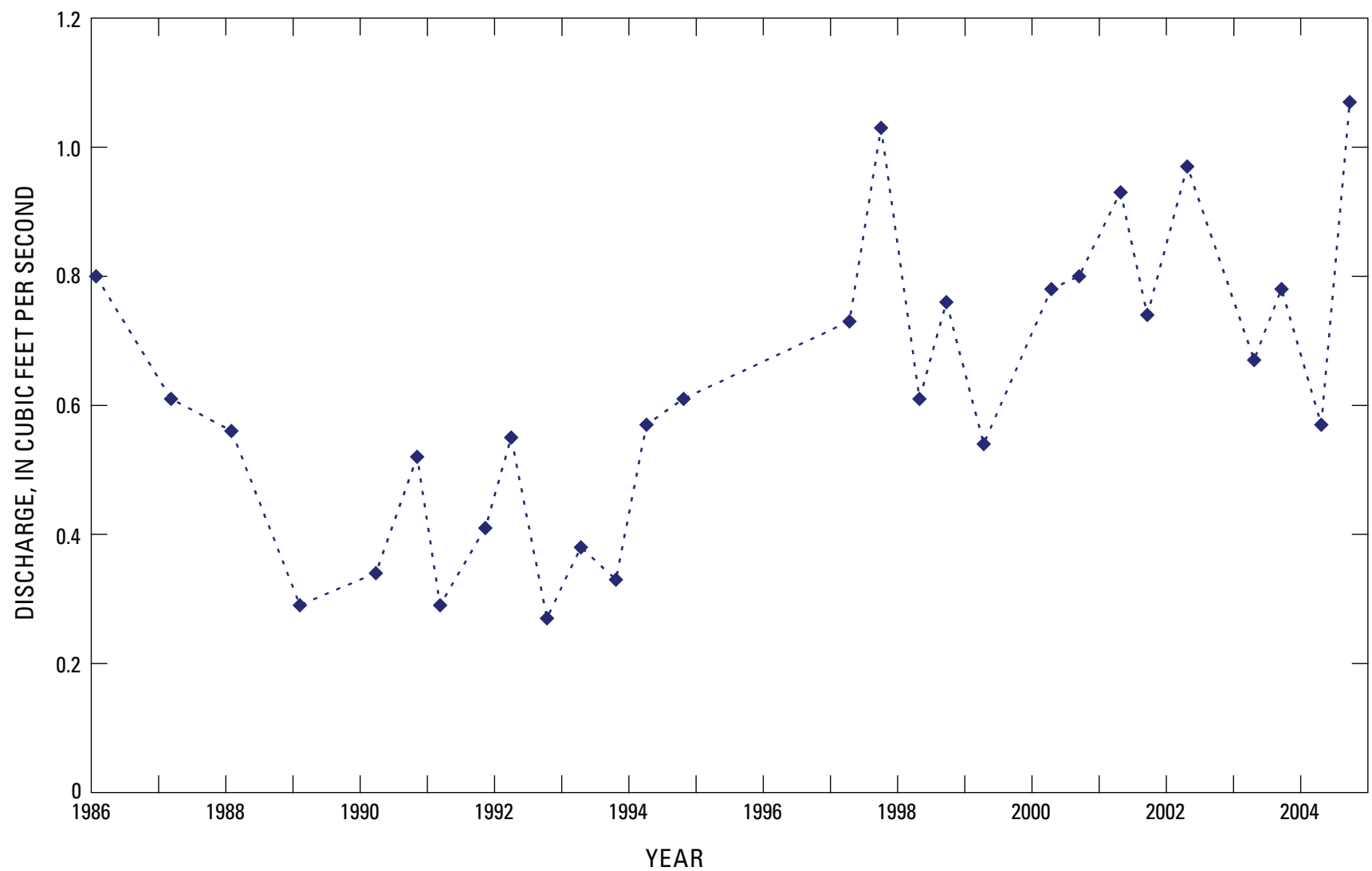

Figure B37. Periodic discharge measurements for stream-gaging station 364236114425401 Muddy River Springs 13 (M-13) near Moapa, Nevada, 1986-2004. 
Table B25. Periodic discharge measurements for partial-record stream-gaging station 36426114425401 Muddy River Springs 13 (M-13) near Moapa, Nevada, 1986-2004.

Table B25 data are available in an Excel data base for download at URL: http://pubs.water.usgs.gov/ofr2006-1311. 


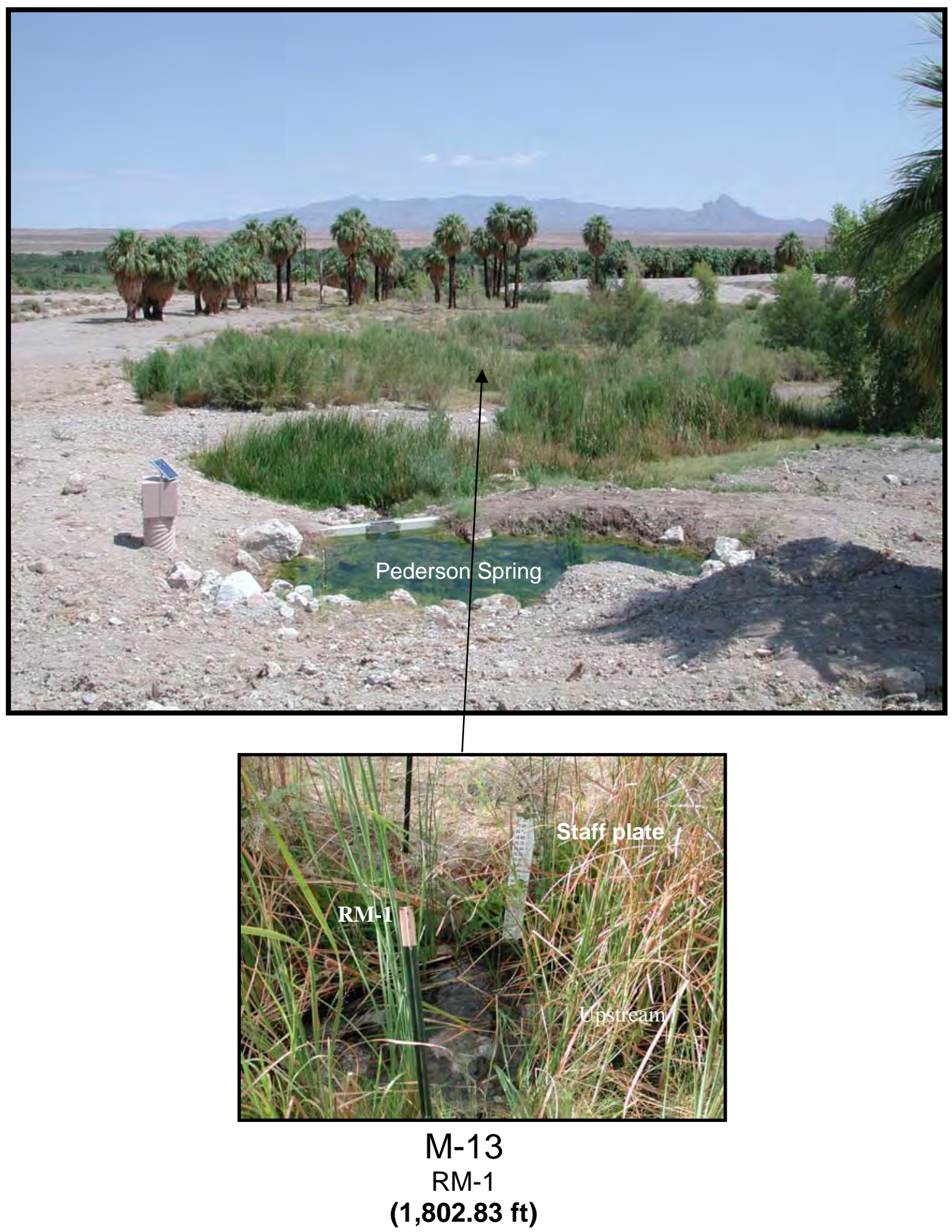

Figure B38. Location of staff plate and reference mark (RM-1) for partial-record stream-gaging station Muddy River Springs 13 (M-13) in the Moapa Valley National Wildlife Refuge near Moapa, Nevada. Photographed June 9, 2004 by D. Beck. Elevation in feet above NAVD 88. 
Table B26. Water-quality data collected by Desert Research Institute at station 364236114425401 Muddy River Springs 13 (M-13) near Moapa, Nevada, January 12 and May 18, 2004.

Table B26 data are available in an Excel data base for download at URL: http://pubs.water.usgs.gov/ofr2006-1311. 


\section{Muddy River Springs 19 (M-19) near Moapa, Nevada}

The partial-record stream-gaging station at Muddy River Springs 19 (M-19) was established by the U.S. Geological Survey (USGS) on April 28, 1990, and is about $100 \mathrm{ft}$ downstream from the Pederson East Spring gage (fig. B26). Flow at Muddy River Springs 19 originates from water discharging at the Pederson East Spring pool and from three other spring pools downstream of the gage. Flow at M-19 drains to the northeast and joins with flow from Pederson Spring approximately $50 \mathrm{ft}$ downstream.
Periodic discharge measurements have been made by the USGS since April 1998. Discharge measurements for the period of record are plotted in figure B39 and listed in table B27. Photographs of the staff plate and a selected reference mark established for the Muddy River Springs 19 monitoring site on June 9, 2004, are included in figure B40. 
Water-Surface Elevations, Discharge, and Water-Quality Data in the Warm Springs Area near Moapa, Nevada

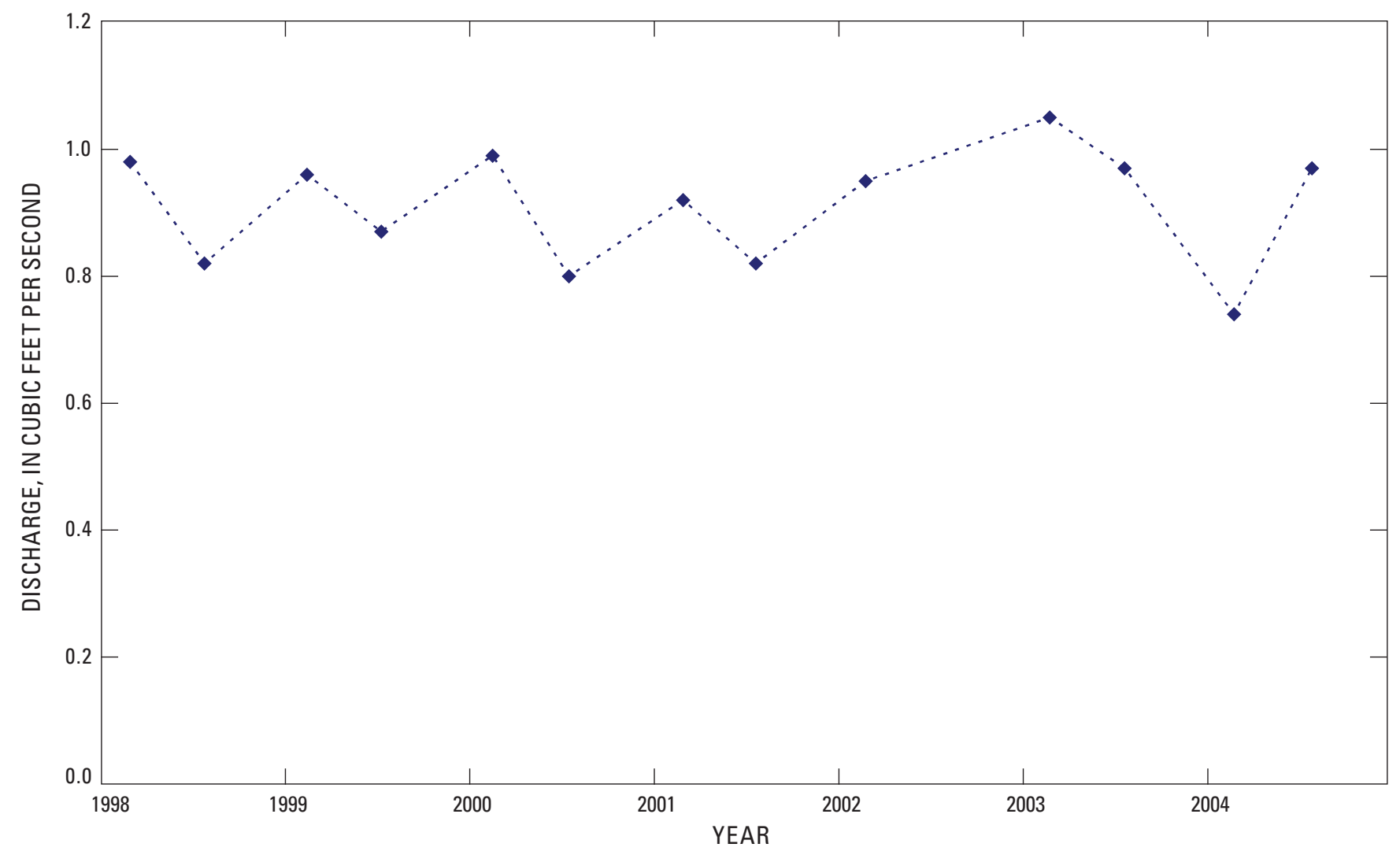

Figure B39. Periodic discharge measurements for partial-record stream-gaging station 3642235114425301 Muddy River Springs 19 (M-19) near Moapa, Nevada, 1998-2004. 
Table B27. Periodic discharge measurements for partial-record stream-gaging station 364235114425301 Muddy River Springs 19 (M-19) near Moapa, Nevada, 1998-2004.

Table B27 data are available in an Excel data base for download at URL: http://pubs. water.usgs.gov/ofr2006-1311. 


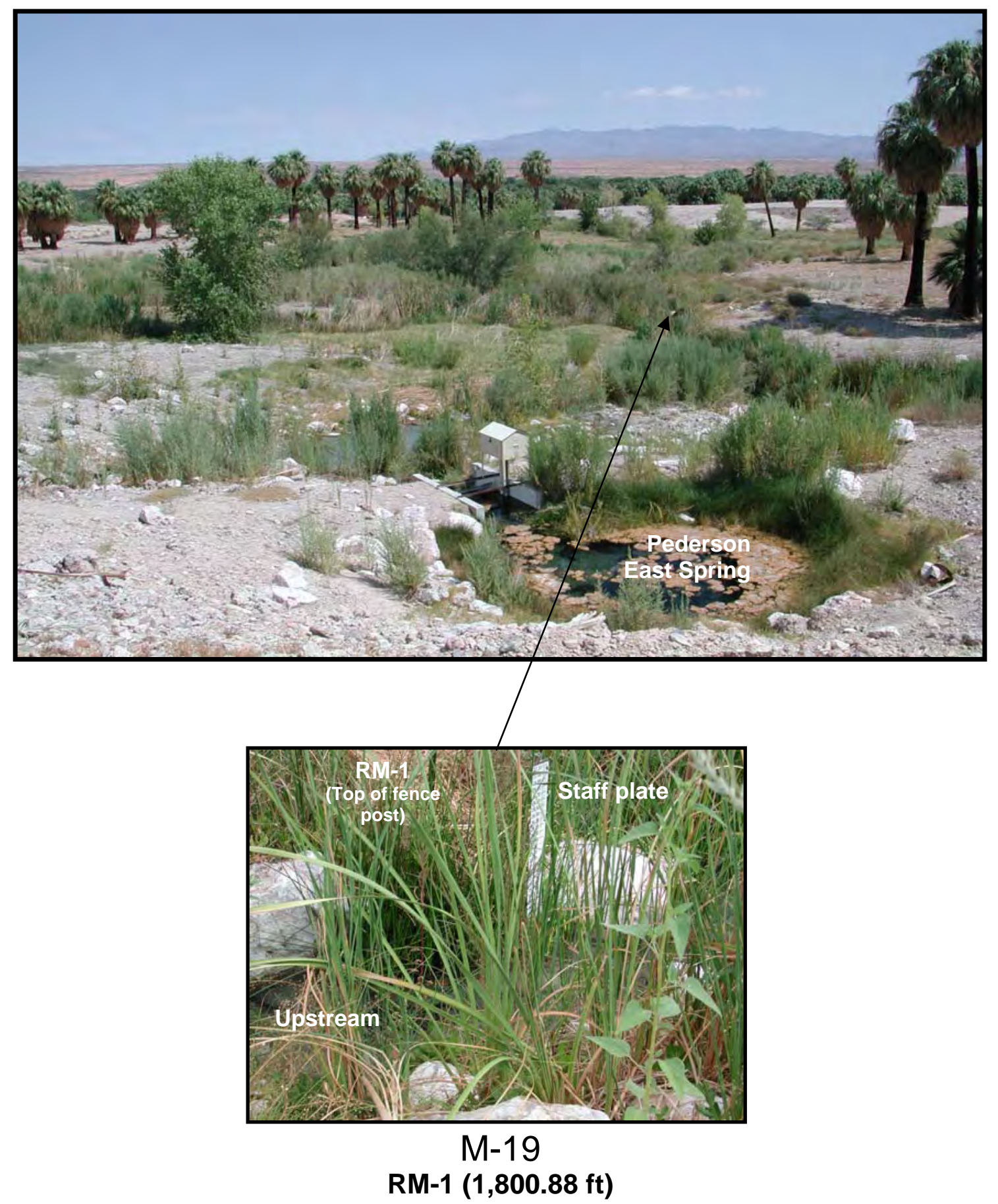

Figure B40. Location of staff plate and reference mark (RM-1) for partial-record stream-gaging station Muddy River Springs 19 (M-19) in the Moapa Valley National Wildlife Refuge near Moapa, Nevada. Photographed June 9, 2004 by D. Beck. Elevation in feet above NAVD 88. 


\section{Warm Springs West near Moapa, Nevada}

A 1.5-foot (ft) Parshall flume was installed at the Warm Springs West stream-gaging station on September 20, 1967, by the Nevada Division of Water Resources (NDWR). Initially called the Pederson flume by NDWR, the exact location is unknown, but the flume is believed to have been installed in the vicinity of the current gage, just upstream of Warm Springs Road (fig. B41). At this site, the flume would have monitored the total flow discharging from all springs associated with the Pederson Spring Groups (fig. B26). Downstream from the flume, flow discharges under Warm Springs Road and then turns sharply to the east after exiting the culvert. About $0.1 \mathrm{mi}$ below the culvert, flow merges with discharge draining the Plummer (Iverson) Spring Group.

Data provided by NDWR show that water levels at the Pederson flume generally were measured monthly from October 1967 to July 1981. A large gap in the record is evident from August 1971 to March 1974. Additional data provided by NDWR showed that a 1-ft Parshall flume, called the U.S. Fish and Wildlife Flume, was installed on May 6, 1981. The exact location of this flume also is unknown, but it is believed that it was near the location of the current gage. Water levels were concurrently measured at the Pederson and the Fish and Wildlife flumes during May, June, and July 1981. Water levels for the Fish and Wildlife Flume were measured daily from June 29, 1981, to September 27, 1981, and measured somewhat monthly from October 1981 to June 1986. Measurements were not available for July 1986 to July 1993 when a new 1-ft Parshall flume was installed. Monthly measurements resumed and continued though February 2005.
As only water-level measurements were provided by NDWR, discharge rates were computed using standard equations for the 1.5-ft and 1-ft Parshall flumes (Leupold and Stevens, 1987). Plots of the computed discharges from October 1967 to February 2005 are shown in figure B42. Listings of the water-level measurements and computed discharges are included in table B28 for October 1967 to July 1981; table B29 for May 1981 to June 1986; and table B30 for July 1993 to February 2005. Computed discharges from March 1974, after the large gap in record, until July 1981 are significantly lower than all other computed discharges. Although not noted in the records received from NDWR, the drop in discharge probably was the result of flow bypassing the flume.

A continuous-stage recorder was installed by the U.S. Geological Survey (USGS) on August 22, 1985, and maintained through September 30, 1994. The gage was reactivated in June 1996 and is routinely maintained as part of the current monitoring network. Daily mean discharges computed for the period of record have been included on the plot in figure B42 and listed in table B31. Photographs of the current flume and bench mark, and a selected reference mark established for this gage on June 3, 2004, are shown in figure B43.

Quarterly measurements of water temperature and specific conductance made at this gage from April 1997 to March 2005 were provided from Converse Consultants. These data are plotted on figure B44 and listed in table B32. 


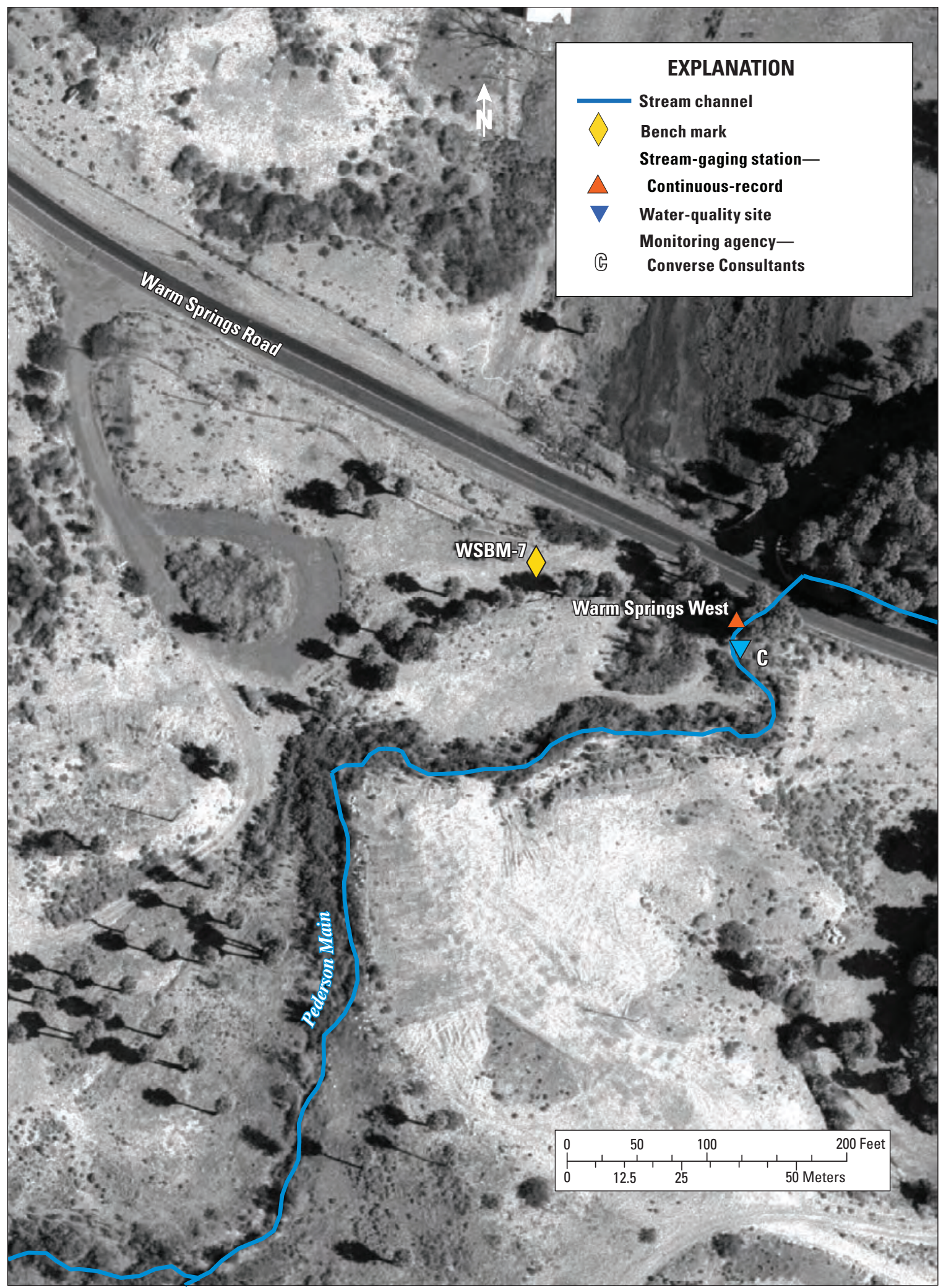

Figure B41. Location of continuous-record stream-gaging station 09415920 Warm Springs West and bench mark WSBM-7 in the Warm Springs area near Moapa, Nevada. 


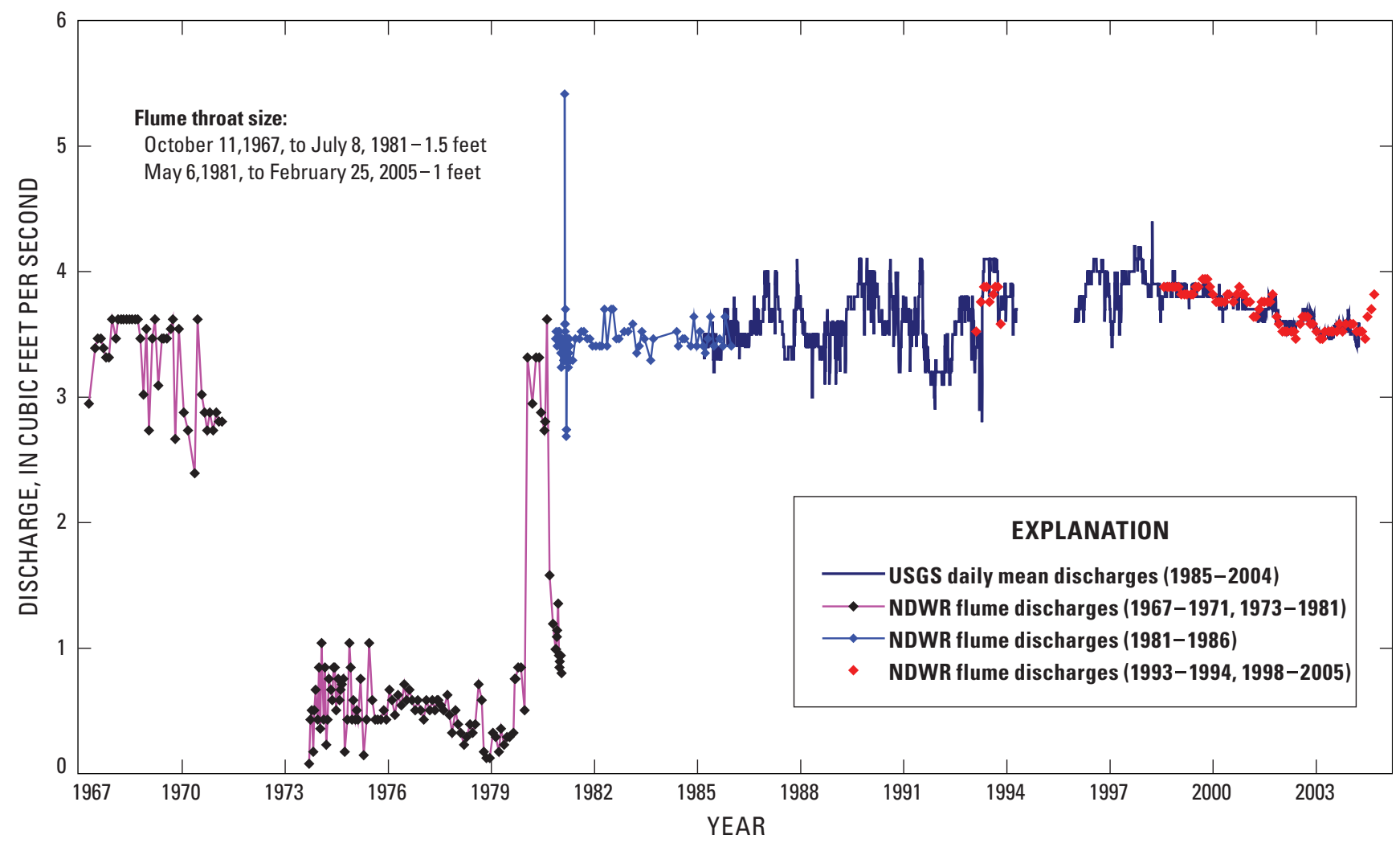

Figure B42. Instantaneous and daily mean discharges for continuous-record stream-gaging station 09415920 Warm Springs West near Moapa, Nevada, 1967-2005. Data from U.S. Geological Survey (USGS) National Water Information System (NWIS) data base, accessed 2005 at http://waterdata.usgs.gov. NDWR, Nevada Division of Water Resources. 
Table B28. Water levels and computed instantaneous discharges for Pederson Flume near Moapa, Nevada, 1967-81.

[Data from Nevada Division of Water Resources.]

Table B28 data are available in an Excel data base for download at URL: http://pubs.water.usgs.gov/ofr2006-1311. 
Table B29. Water levels and computed instantaneous discharges for U.S. Fish and Wildlife Service flume near Moapa, Nevada, $1981-86$.

[Data from Nevada Division of Water Resources.]

Table B29 data are available in an Excel data base for download at URL: http://pubs.water.usgs.gov/ofr2006-1311. 
Table B30. Water levels and computed instantaneous discharges for U.S. Fish and Wildlife Service flume near Moapa, Nevada, 1993-2005.

[Water levels provided by Nevada Division of Water Resources.]

Table B30 data are available in an Excel data base for download at URL: http://pubs.water.usgs.gov/ofr2006-1311. 
Table B31. Daily mean discharges for continuous-record stream-gaging station 09415920 Warm Springs West near Moapa, Nevada, water years 1985-2004.

[Data from U.S. Geological Survey (USGS) National Water Information System (NWIS) data base, accessed 2005 at http://waterdata.usgs.gov]

Table B31 data are available in an Excel data base for download at URL: http://pubs.water.usgs.gov/ofr2006-1311. 

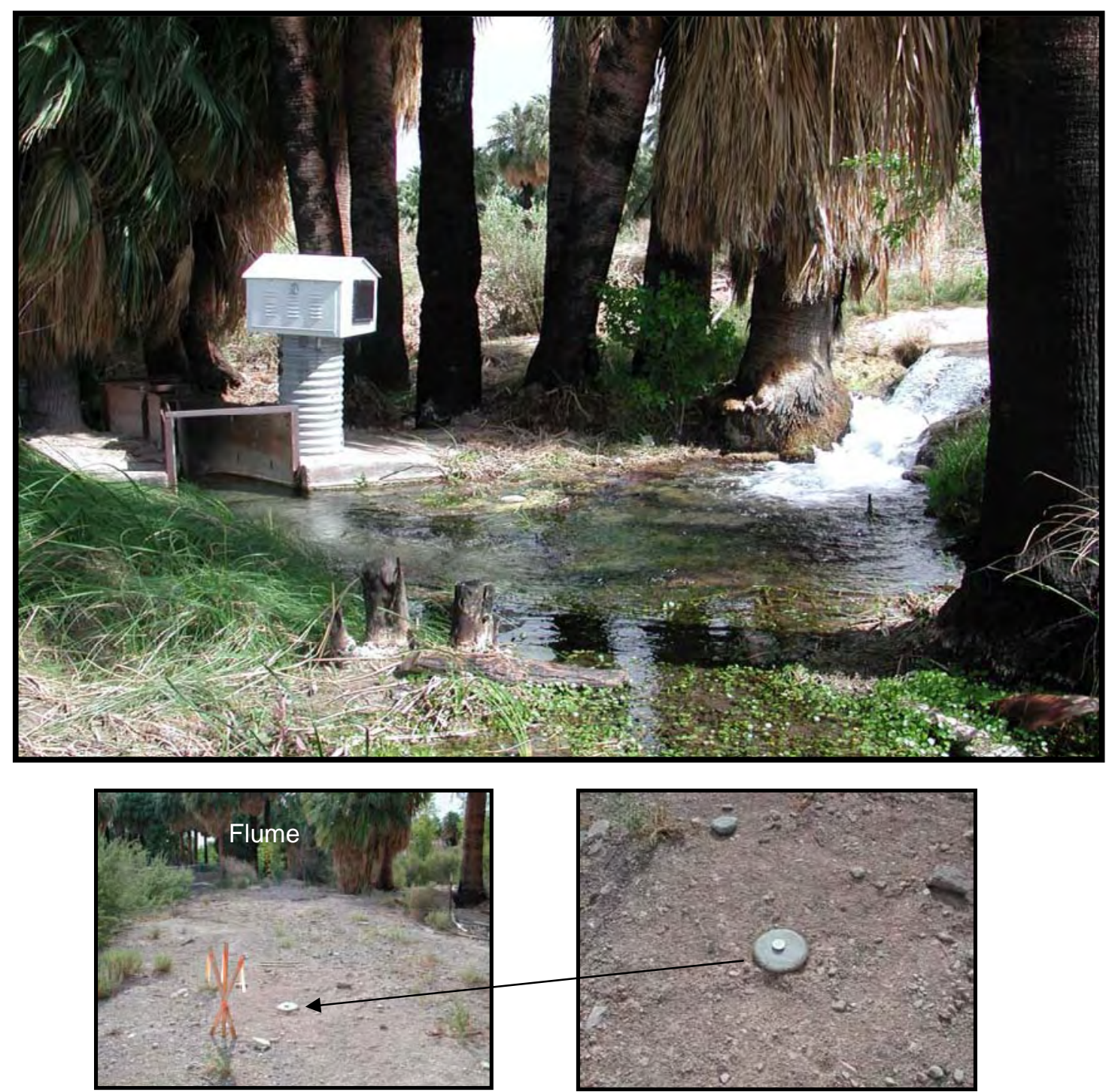

WSBM-7

$(1,776.93 \mathrm{ft})$

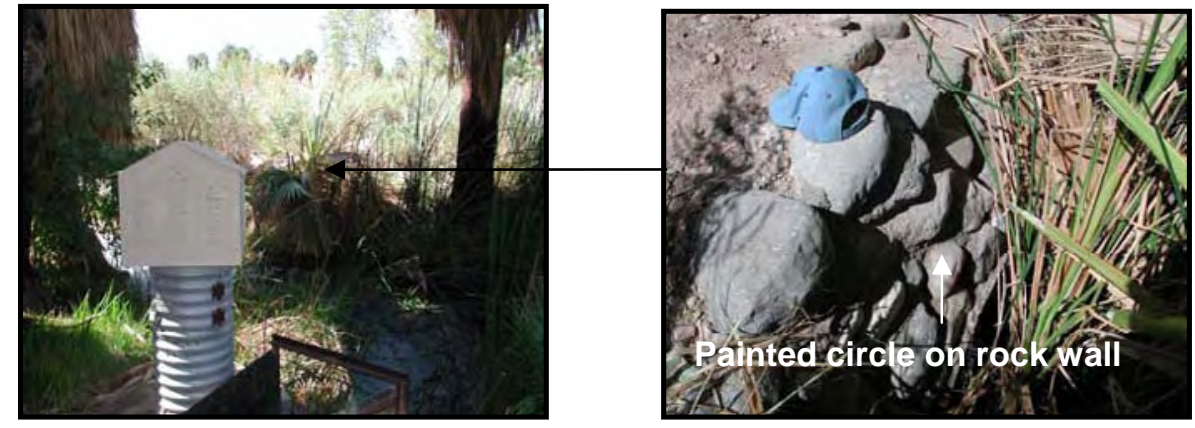

RM-1

$(1,772.94 \mathrm{ft})$

Figure B43. Location of bench mark WSBM-7 and reference mark RM-1 for continuous-record stream-gaging station 09415920 Warm Springs West near Moapa, Nevada. The top picture shows the stream-gaging station photographed in 2001. Elevation of bench and reference marks in feet above NAVD 88. 


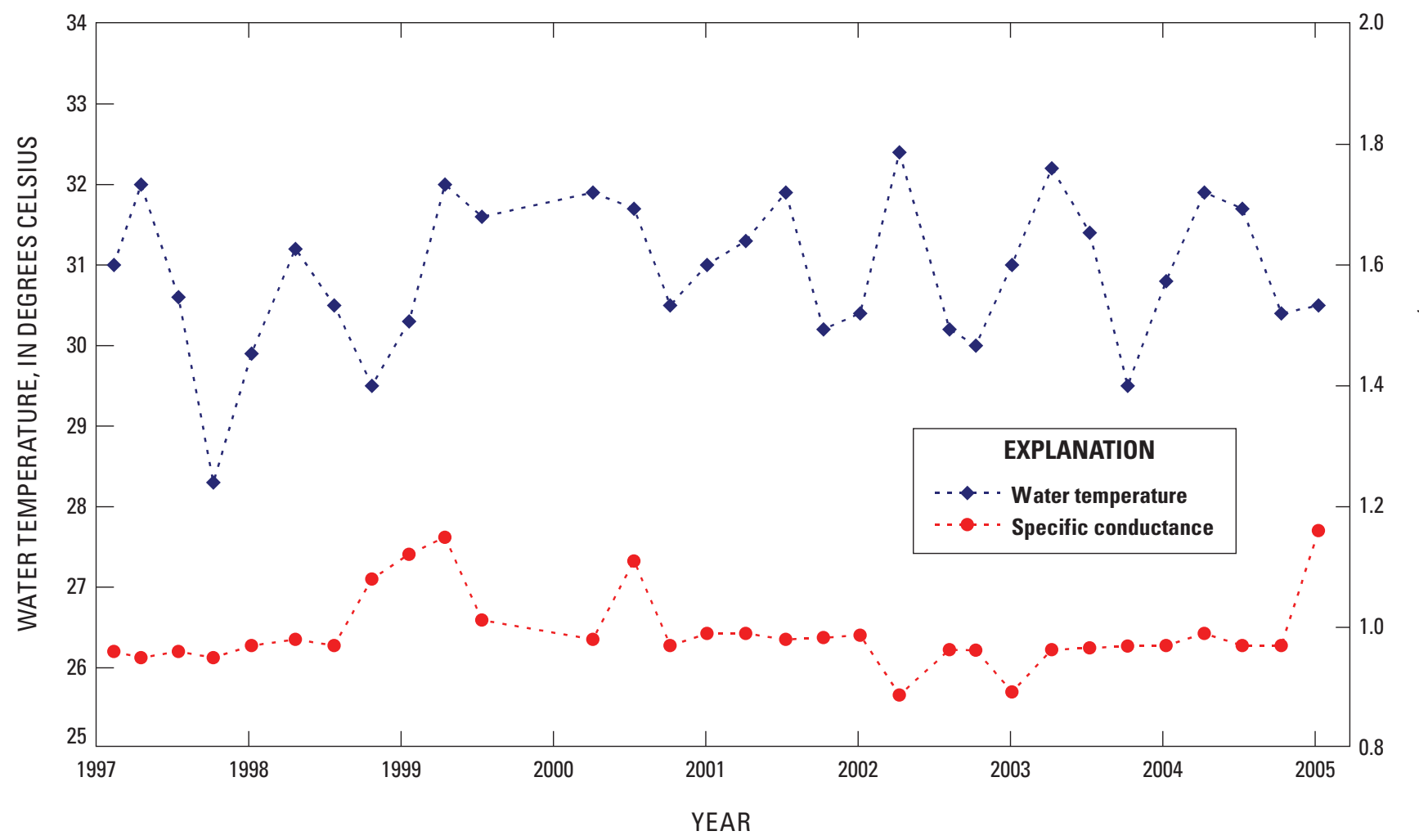

Figure B44. Water temperature and specific conductance measurements for continuous-record stream-gaging station 09415920 Warm. Springs West near Moapa, Nevada, 1997-2005. Data provided by Converse Consultants. 
Table B32. Water-temperature and specific-conductance measurements by Converse Consultants at continuous-record streamgaging station 09415920 Warm Springs West near Moapa, Nevada, 1997-2005.

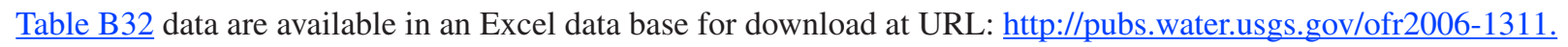




\section{Muddy Springs}

The following site is included within this section:

09415900 Muddy Springs at L.D.S. Farm near Moapa, Nevada (1967-2005) 


\section{Muddy Springs at L.D.S. Farm near Moapa, Nevada}

A 1-foot (ft) Parshall flume was installed on Muddy (Big) Springs on August 25, 1967, by the Nevada Division of Water Resources (NDWR). The flume was located approximately 0.1 mi downstream from the former Francis Taylor mansion (fig. B45) located on the L.D.S. Recreation Area. Although there are several springs in the area, most flow emanates from a large spring-fed pond on the northwest side of the mansion. Discharge from the spring-fed pond is directed around both sides of the mansion and converges just north of the large swimming pool. From there, flow generally drains to the south and joins with Muddy River about $0.5 \mathrm{mi}$ downstream. Springflow is frequently diverted to fill the large swimming pool.

Data provided by NDWR show that water levels in the 1-ft flume were measured monthly from August 1967 to August 1971. Measurements were not available between September 1971 and February 1974 at which time a larger (3-ft) Parshall flume was installed. Monthly measurements resumed and continued until November 1987, although during July and August 1981, daily readings were recorded. Between December 1987 to July 1993 only six measurements were made. On July 16, 1993, a new 3-ft Parshall flume was installed and monthly measurements resumed. Because only water-level measurements were provided by NDWR, discharge rates were computed using standard equations for the $1-\mathrm{ft}$ and 3-ft Parshall flumes (Leupold and Stevens, 1987). Discharges for October 1967 to February 2005 are shown in figure B46. A complete listing of the water-level measurements and computed discharges is included in table B33.

A continuous-stage recorder was installed on the flume by the U.S. Geological Survey on August 22, 1985, and maintained until September 30, 1994. The gage was reactivated in June 1996 and is routinely maintained as part of the current monitoring network. Daily mean discharges computed for the period of record are also plotted on figure B46 and listed in table B34. Photographs of the current flume, bench mark, and selected reference marks established for this gage on June 3, 2004, are shown in figure B47.

Water samples were collected at this site on May 18, 2004, by Desert Research Institute (DRI) and analyzed for major ions, water temperature, and stable hydrogen and oxygen isotopes. The results of the analyses are shown in table B35. 


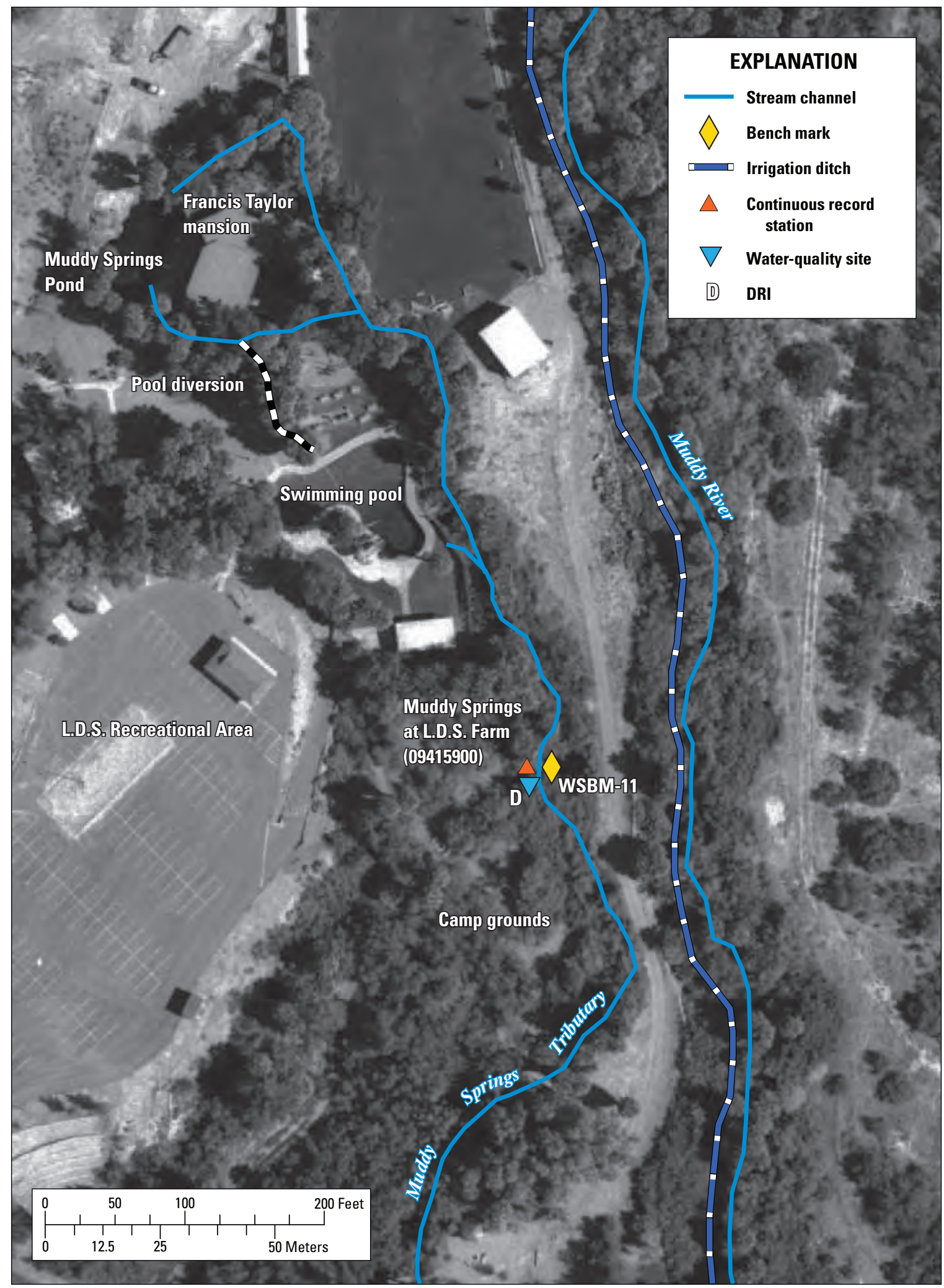

Figure B45. Location of Muddy Springs at Latter Day Saints (L.D.S.) Farm continuous-record stream-gaging station, L.D.S. Recreational Area, Desert Research Institute monitoring site, and bench mark WSBM-11 in the Warm Springs area near Moapa, Nevada. 


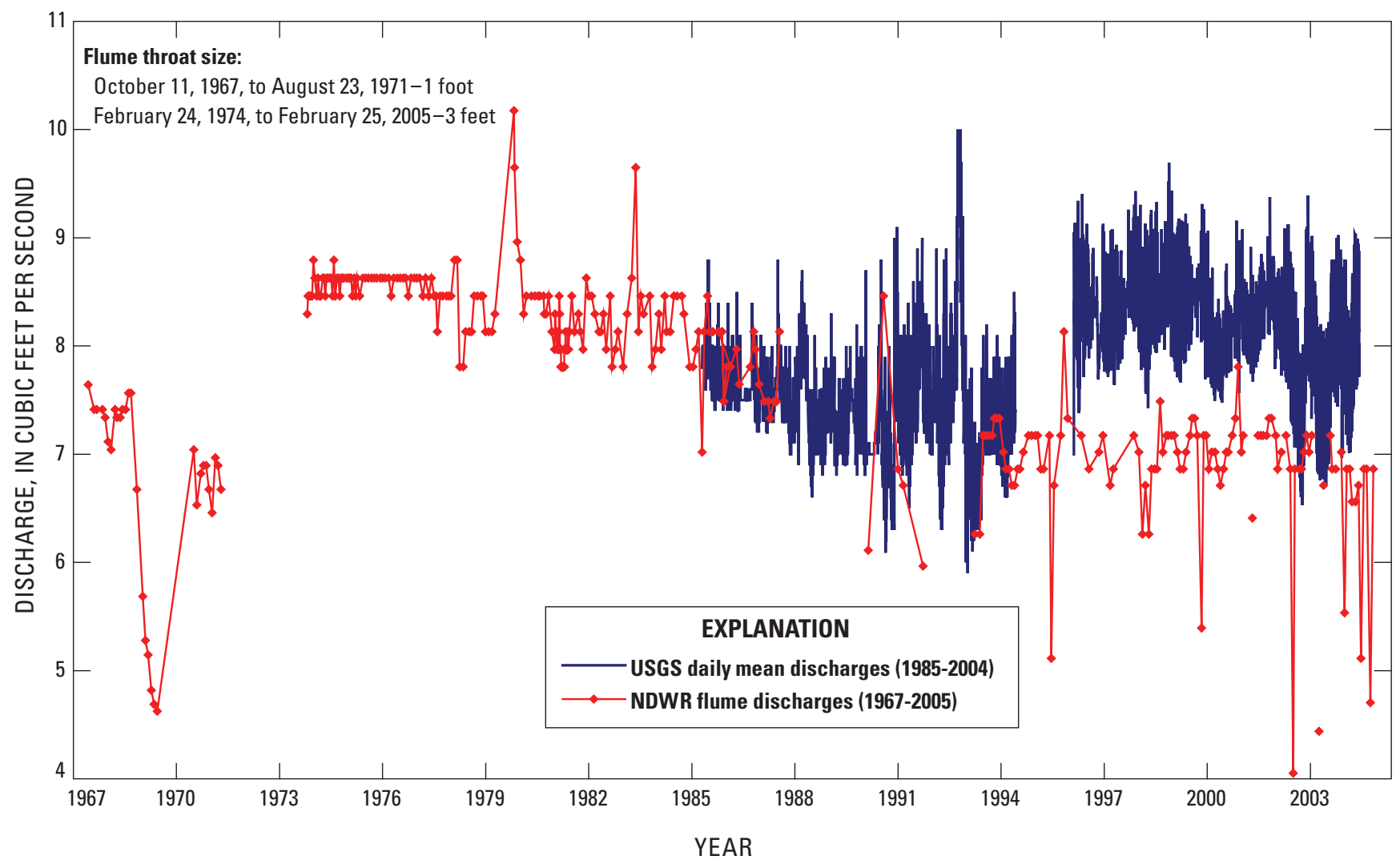

Figure B46. Instantaneous and daily mean discharge for continuous-record stream-gaging station 09415900 Muddy Springs at Latter Day Saints (L.D.S.) Farm near Moapa, Nevada, 1967-2005. Data from U.S. Geological Survey (USGS) National Water Information System (NWIS) data base, accessed 2005 at http://waterdata.usgs.gov. NWDR, Nevada Division of Water Resources. 
Table B33. Water levels and computed instantaneous discharges for continuous-record stream-gaging 097415900 Muddy Springs at L.D.S. Farm near Moapa, Nevada, 1967-2005.

Table B33 data are available in an Excel data base for download at URL: http://pubs.water.usgs.gov/ofr2006-1311. 
Table B34. Daily mean discharges for continuous-record stream-gaging station 09415900 Muddy Springs at L.D.S. Farm near Moapa, Nevada, water years 1985-2004.

Table B34 data are available in an Excel data base for download at URL: http://pubs.water.usgs.gov/ofr2006-1311. 


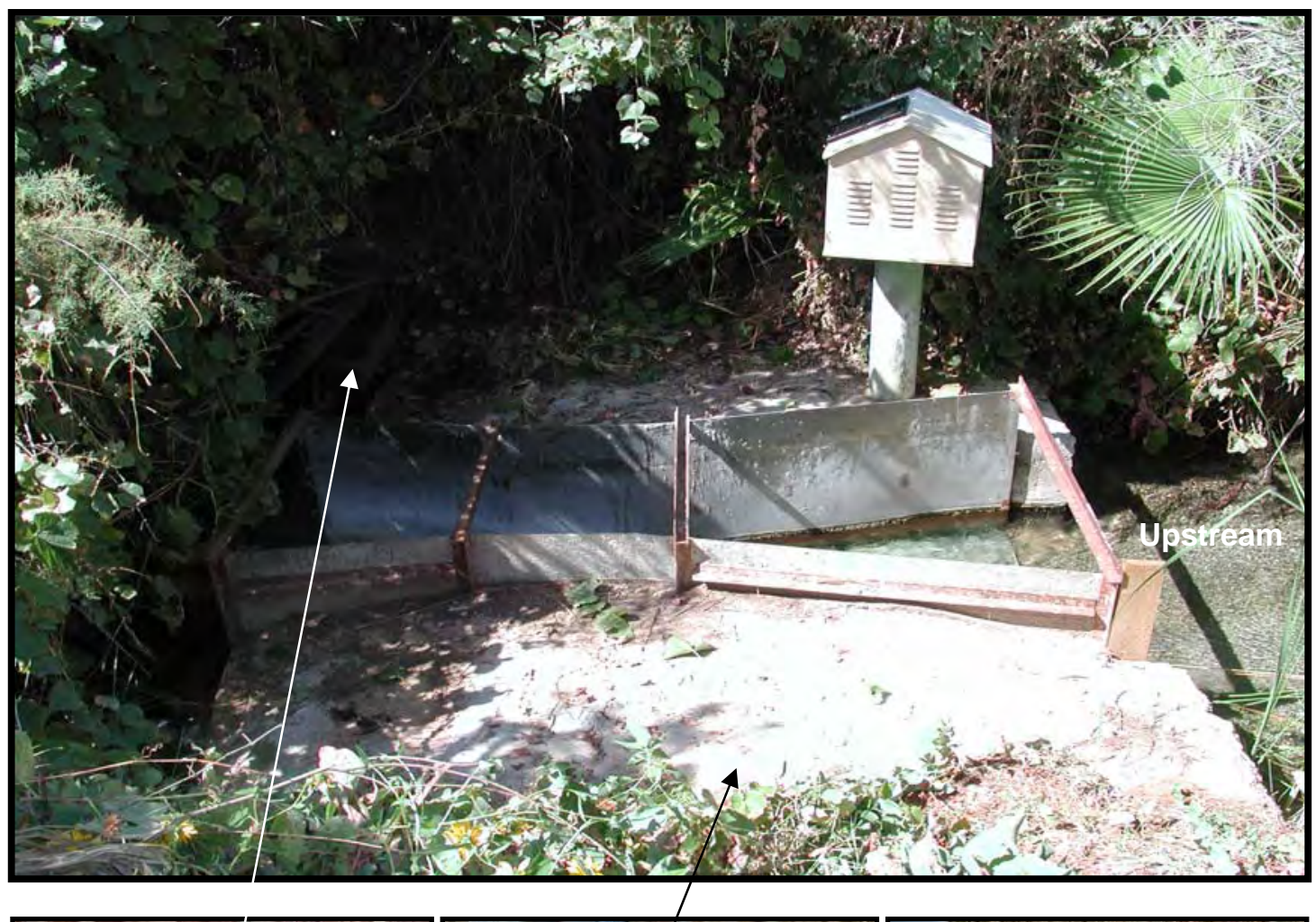

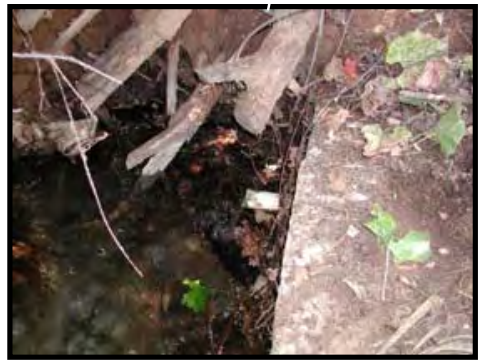

RM-3

$(1,745.14 \mathrm{ft})$

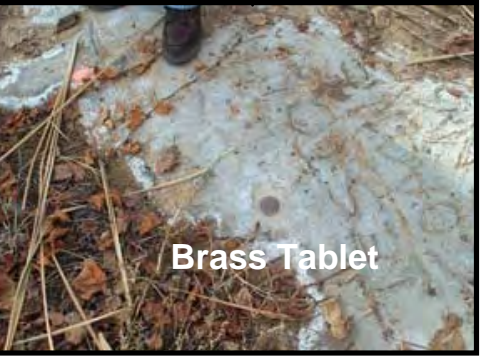

WSBM-11

$(1,747.23 \mathrm{ft})$

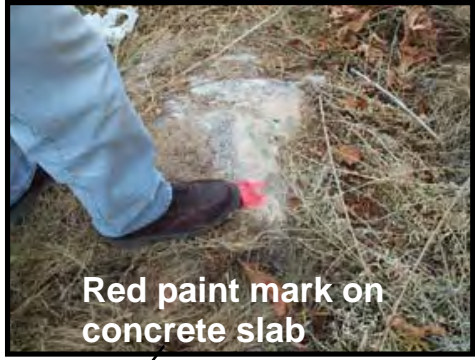

RM-5

$(1,753.27 \mathrm{ft})$

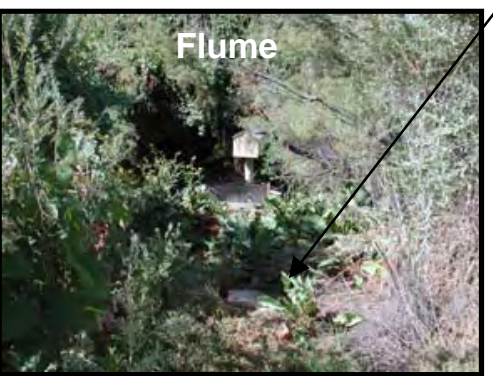

Figure B47. Location of bench mark WSBM-11 and reference marks RM-3 and RM-5 at stream-gaging station 09415900 Muddy Springs at L.D.S. Farm near Moapa, Nevada. Photographed June 3, 2004 by D. Beck. Elevation of bench and reference marks in feet above NAVD 88. 
Table B35. Water-quality data collected by Desert Research Institute for continuous-record stream-gaging at station 09415900 Muddy Springs at L.D.S. Farm near Moapa, Nevada, May 18, 2004.

Table B35 data are available in an Excel data base for download at URL: http://pubs.water.usgs.gov/ofr2006-1311. 


\section{Apcar (Pipeline Jones) Springs}

The following sites are included within this section:

Garden Ditch Flume (1978-92)

North Tributary Water-Quality Site (1997-2005)

South Tributary Water-Quality Site (1997-2005)

Apcar Pumphouse Water-Quality Site (1997-2004) 


\section{Apcar (Pipeline Jones) Springs near Moapa, Nevada}

Apcar Springs is about 0.1 mi west of Warm Springs Road in the south-central part of the Warm Springs area (fig. 2). Currently, two channels, the North Tributary and South Tributary, discharge water from the Apcar Spring area. The North Tributary drains to the northeast through a culvert under Warm Springs Road (fig. B48). Downstream of Warm Springs Road, flow continues in a dirt channel to the north for about $0.1 \mathrm{mi}$ and then turns to the northeast. About 0.2 mi farther, the channel turns to the southeast and continues until it is just south of the confluence of Muddy Springs tributary and Muddy River (fig. 2). Most of the ditch between Warm Springs Road and the confluence is thickly overgrown. Near the confluence, flow from the ditch is directed into an old concrete irrigation trough that distributes water to the southeast fields, ultimately terminating into Refuge Stream about 0.4 mi downstream (fig. 2). The South Tributary generally drains to the east, eventually becoming Apcar Stream, which terminates into Refuge Stream about $0.55 \mathrm{mi}$ downstream from the Warm Springs Road crossing (fig. 2). In 1960, a pump house (fig. B48) was constructed at the springs by the then Moapa Valley Water Company to supply water for residential and commercial areas within the southern towns of Moapa Valley.

A 9-inch (in.) Parshall flume was installed on Garden Ditch on January 4, 1978, by the Nevada Division of Water Resources (NDWR). This flume is reported to have been located on the North Tributary just upstream of the culvert at Warm Springs Road (fig. B48) (Testolin and others, 1993). The flume is no longer there; however, remnant pieces of concrete litter the area. Data provided by NDWR show that water-level measurements for the 9-in flume generally were made monthly from January 1978 until June 1981 and daily from July through September 1981. Monthly measurements resumed in October 1981 and ended in November 1987. No measurements were made from December 1987 until June 1990. From June 1990 to June 1992, only six measurements were made. No measurements are available after June 26, 1992. Because only water-level measurements were provided by NDWR, discharge rates were computed using a standard equation for the 9-in Parshall flume (Leupold and Stevens, 1987). Computed discharges from January 1978 to June 1992 are shown in figure B49. Waterlevel measurements and computed discharges are given in table B36.

In April 1997, Converse Consultants, on contract with Nevada Power Company, began quarterly field measurements of water temperature and specific conductance on the North and South Tributaries (fig. B48). Measurements for the North and South Tributary sites through March 2005 were provided by Converse Consultants and are plotted in figures B50 and $\underline{\text { B51 }}$ and listed in tables B37 and B38, respectively.

In December 1997, the Moapa Valley Water District (MVWD) began collecting water samples from a spigot at the Apcar Springs old pump house (fig. B48). Water samples generally are collected annually by MVWD and analyzed by Southwest Analytical, Inc., for major ions, trace metals, and selected chemical parameters ( $\mathrm{pH}$, specific conductance, total dissolved solids, and alkalinity). Although a new pump house was constructed during the summer of 2004 (fig. B48), all water-quality data provided by MVWD were from the original pump house (Susan Rose, Moapa Valley Water District, oral commun., 2005). The results of the analyses of the samples collected from December 1997 to August 2004 are given in table B39. 


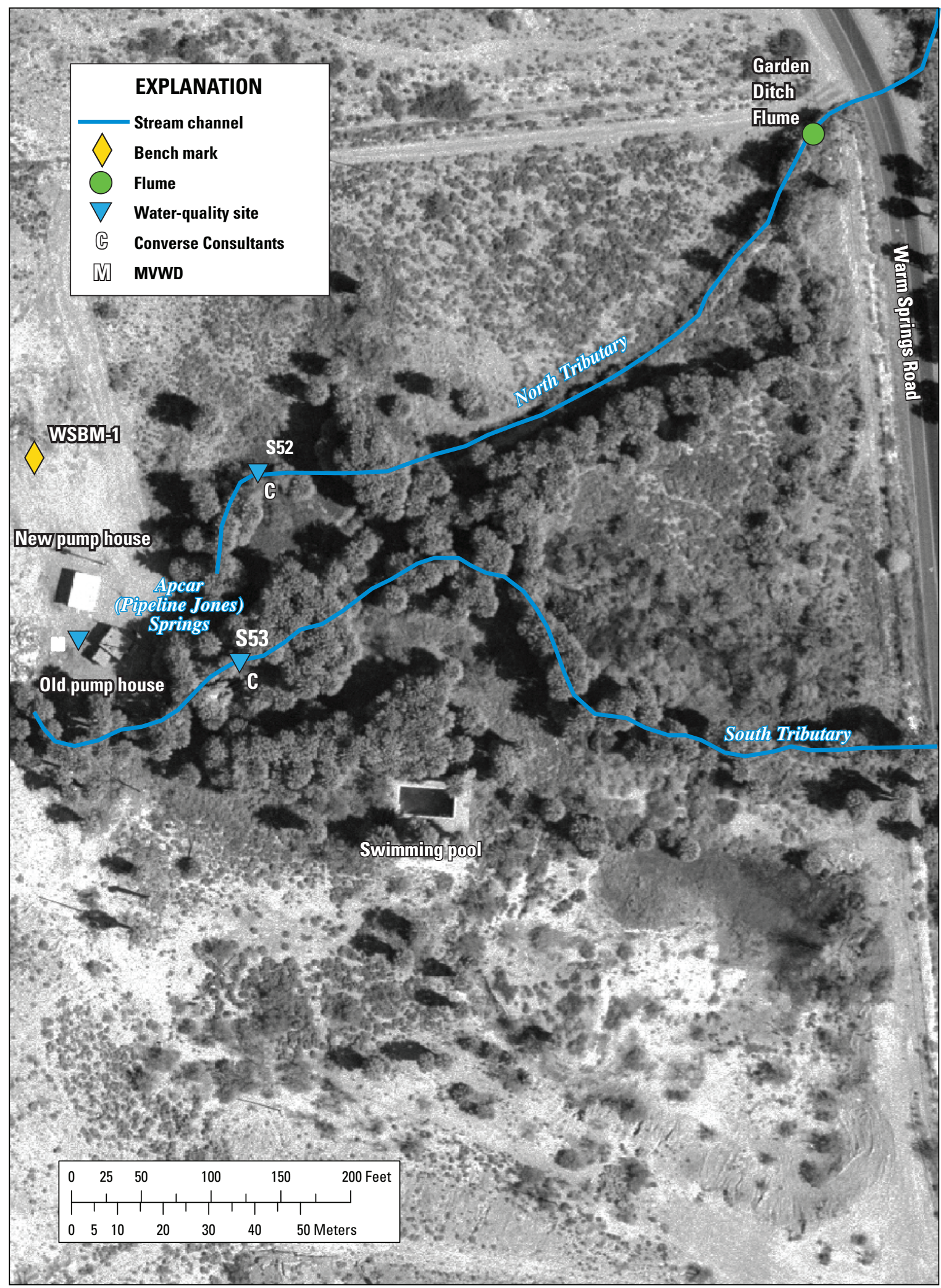

Figure B48. Location of Apcar (Pipeline Jones) Springs, pump houses, monitoring sites, and bench mark WSBM-1 in the Warm Springs area near Moapa, Nevada. 


\section{Garden Ditch Flume at Apcar (Pipeline Jones) Springs near Moapa, Nevada}

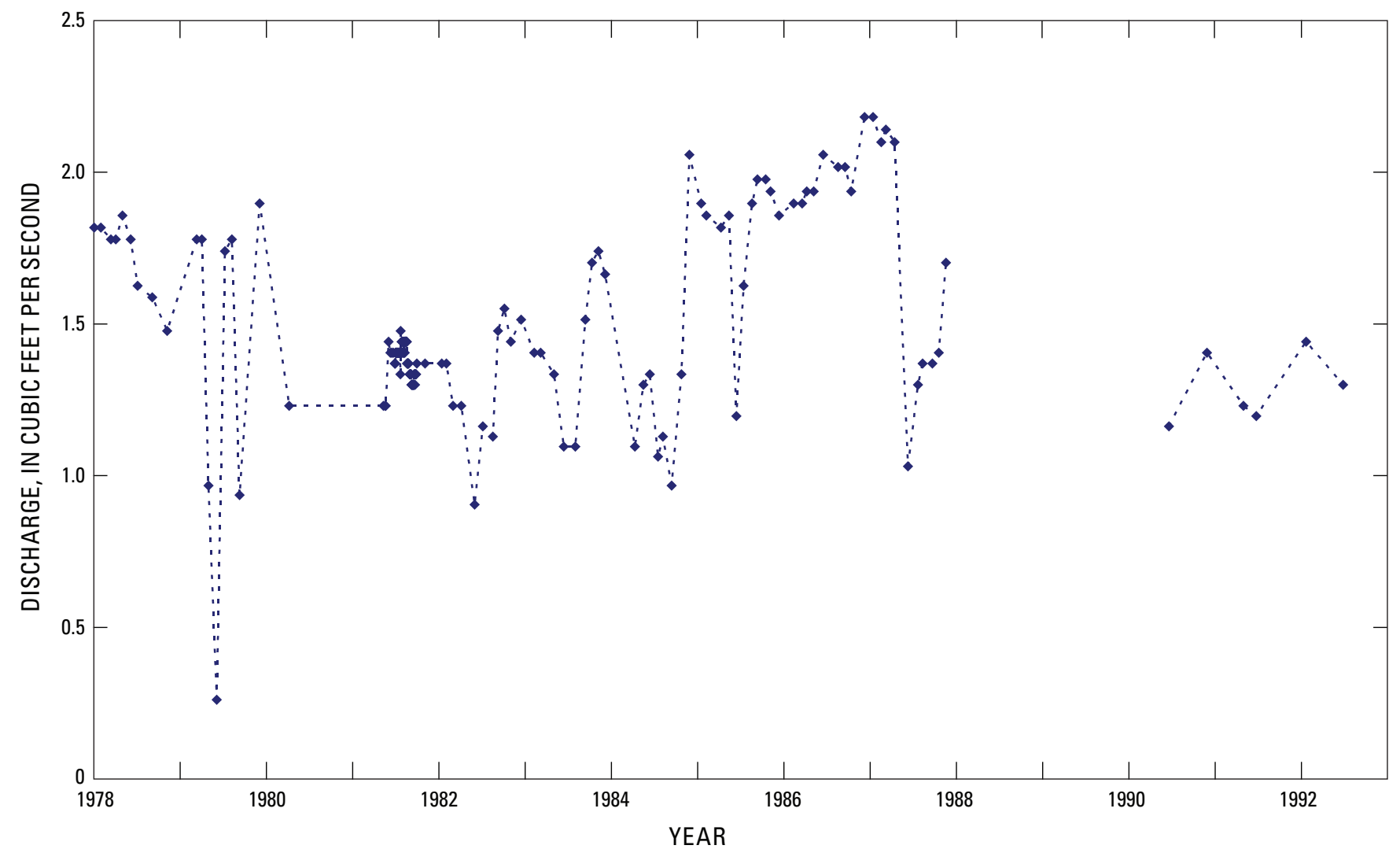

Figure B49. Instantaneous discharges computed from water-level measurements provided by Nevada Division of Water Resources for Garden Ditch Flume on North Tributary at Apcar (Pipeline Jones) Springs near Moapa, Nevada, $1978-92$. Data provided by Nevada Division of Water Resources. 
Table B36. Instantaneous discharges computed from water-level measurements for Garden Ditch Flume on North Tributary at Apcar (Pipelne Jones) Springs near Moapa, nevada, 1978-92.

[Data provided by Nevada Division of Water Resources.]

Table B36 data are available in an Excel data base for download at URL: http://pubs.water.usgs.gov/ofr2006-1311. 


\section{Water-Quality Sites at Apcar (Pipeline Jones) Springs near Moapa, Nevada}

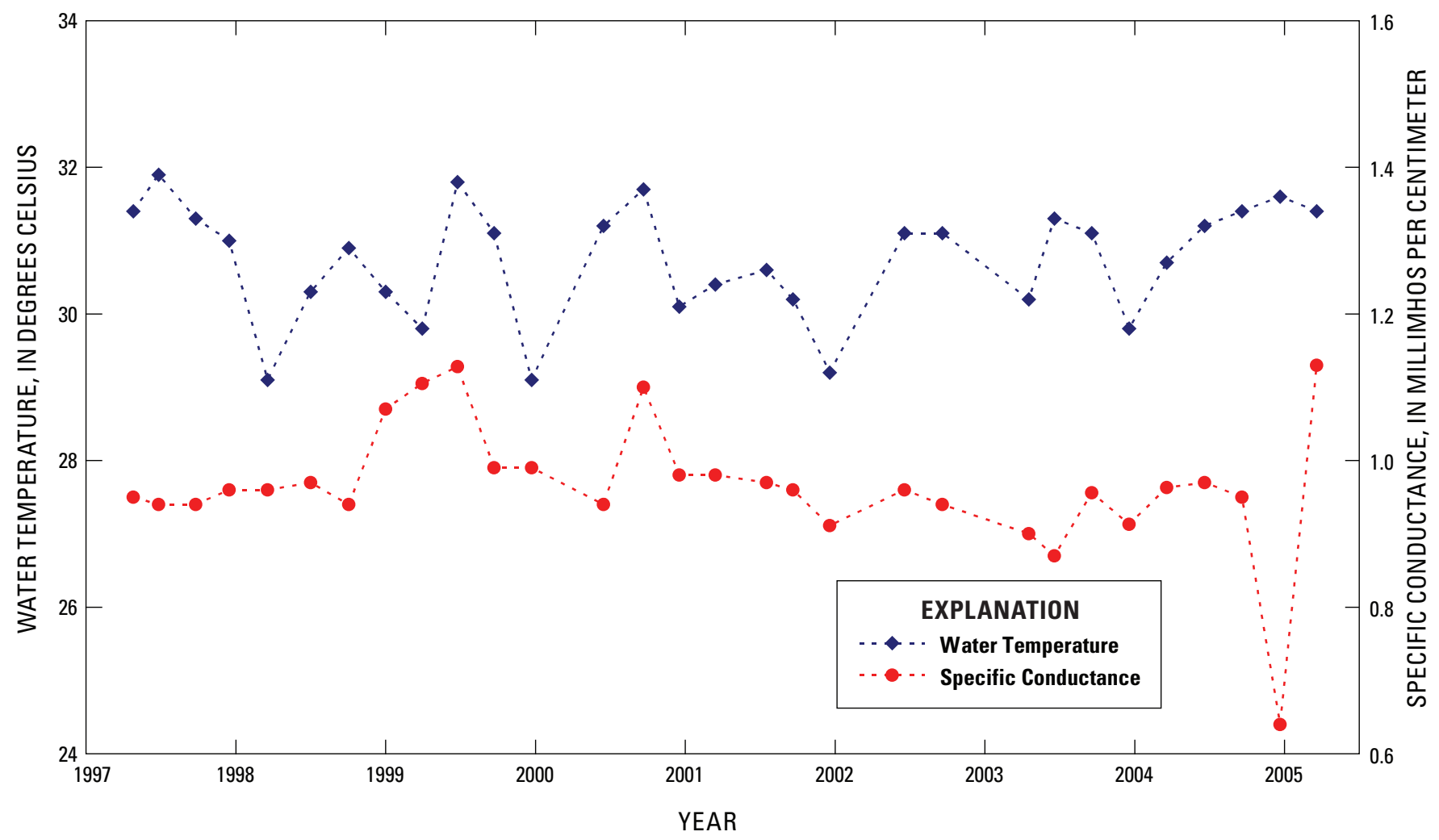

Figure B50. Water-temperature and specific-conductance measurements provided by Converse Consultants for site S52 on North Tributary at Apcar (Pipeline Jones) Springs near Moapa, Nevada, 1997-32005. 


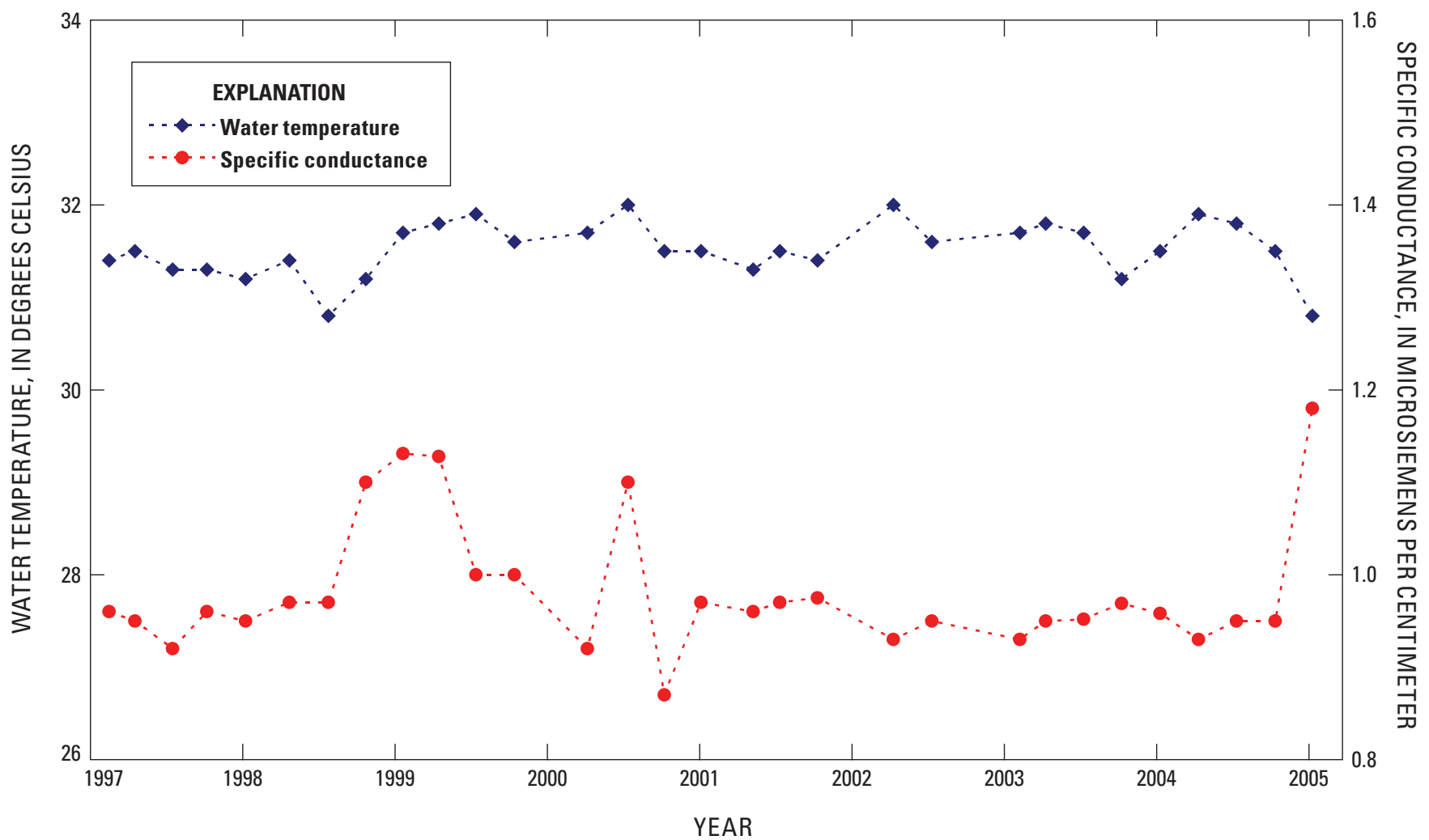

Figure B51. Water-temperature and specific-conductance measurements provided by Converse Consultants for site S53 on South Tributary at Apcar (Pipeline Jones) Springs near Moapa, Nevada, 1997-2005.. 
Table B37. Water-temperature and specific-conductance measurements provided by Converse Consultants for site S52 on North Tributary at Apcar (Pipeline Jones) Springs near Moapa, Nevada, 1997-2005.

Table B37 data are available in an Excel data base for download at URL: http://pubs.water.usgs.gov/ofr2006-1311. 
Table B38. Water-temperature and specific-conductance measurements provided by Converse Consultants for site S53 on South Tributary at Apcar (Pipeline Jones) Springs near Moapa, Nevada, 1997-2005.

Table B38 data are available in an Excel data base for download at URL: http://pubs.water.usgs.gov/ofr2006-1311. 
148 Water-Surface Elevations, Discharge, and Water-Quality Data in the Warm Springs Area near Moapa, Nevada

Table B39. Water-quality data for pump house at Apcar (Pipeline Jones) Springs, near Moapa, Nevada, 1997-2004.

Table B39 data are available in an Excel data base for download at URL: http://pubs.water.usgs.gov/ofr2006-1311. 


\section{Baldwin Springs}

The following sites are included within this section:

Baldwin Cuts Flume (1967-85)

09415875 Baldwin Springs Flume near Moapa, Nevada (1967-2005)

Baldwin Springs Flume Water-Quality Site (1997-2005)

Baldwin Springs Pump House Water-Quality Sites (1997-2004) 


\section{Baldwin Springs near Moapa, Nevada}

Baldwin Springs is about 0.2 mi north of Warm Springs Road and about 0.5 mi west of the L.D.S. Recreation Area (fig. 2). Discharge from the springs generally trends to the northeast, and contributes most of the flow of the South Fork Muddy River (fig. B52). In 1974, a pump house was constructed in the spring area by the Moapa Valley Water District (MVWD) to supply additional water to southern areas of the valley. Water not diverted at the springs is discharged directly into the channel about $20 \mathrm{ft}$ north of the pump house (fig. B52).

A 9-inch (in.) Parshall flume, called Baldwin Cuts Flume, was installed at Baldwin Springs on October 11, 1967, by the Nevada Division of Water Resources (NDWR). The exact location of the flume is unknown, but it is believed to have been installed just downstream from the pump house. Data provided by NDWR show that water-level measurements for the 9-in. flume generally were made monthly October 1967 to August 1971, February 1974 to June 1981, and October 1981 to August 1985. During July, August, and September 1981, daily measurements were recorded. Because only water-level measurements were provided by NDWR, discharge rates were computed using a standard equation for the 9-in. Parshall flume (Leupold and Stevens, 1987). Computed discharges for October 1967 to August 1985 are shown in figure B53. A complete listing of the water-level measurements and computed discharges is given in table B40.

About the same time that the Baldwin Cuts flume was installed, a 1-foot (ft) Parshall flume, the Baldwin Springs Flume, was installed by NDWR on the South Fork Muddy River about $0.25 \mathrm{mi}$ downstream from the pump house and about $75 \mathrm{ft}$ north of Kimball Road (fig. B54). Data provided by NDWR show that monthly readings generally were made from October 1967 to August 1971. Similar to Baldwin Cuts flume, no measurements were made from September 1971 to January 1974. On February 22, 1974, a larger 2-ft Parshall flume was installed and monthly measurements were made until July 1984. On July 15, 1993, a new 2-ft Parshall flume was installed and monthly measurements were made through February 2005. Because only water-level measurements were provided by NDWR, discharge rates for this site were computed using standard equations for the 1-ft and 2-ft Parshall flumes (Leupold and Stevens, 1987). Computed discharges from October 1967 to February 2005 are given in figure B53, which also includes the measurements computed for the Baldwin Cuts Flume. A complete listing of the waterlevel measurements and computed discharges is given in table B41.

In April 1997, Converse Consultants, on contract with Nevada Power Company, began making quarterly field measurements of water temperature and specific conductance at the Baldwin Springs Flume. Measurements were compiled through March 2005 and are plotted in figure B55 and listed in table B42.

On June 2, 2004, the U.S. Geological Survey established bench mark WSBM-12 (table 2) and several reference marks (table 3 ) at Baldwin Springs Flume to determine watersurface elevations. Photographs of the flume, bench mark, and selected reference marks are included in figure B56.

In December 1997, the Moapa Valley Water District (MVWD) began collecting water samples from a spigot at the Baldwin Springs pump house (fig. B52). Water samples generally were collected annually by MVWD and analyzed by Southwest Analytical, Inc. for major ions, trace metals, and selected chemical and physical parameters $(\mathrm{pH}$, specific conductance, total dissolved solids, and alkalinity). The results of the analyses of samples collected from December 1997 to August 2004 were provided by the MVWD are given in table B43.

On January 12 and May 18, 2004, water samples were collected at the pump house by Desert Research Institute and analyzed for major ions, selected chemical and physical parameters ( $\mathrm{pH}$, specific conductance, and dissolved solids), and stable hydrogen and oxygen isotopes. The results of the analyses are shown in table B44. 


\section{Baldwin Cuts Flume near Moapa, Nevada}

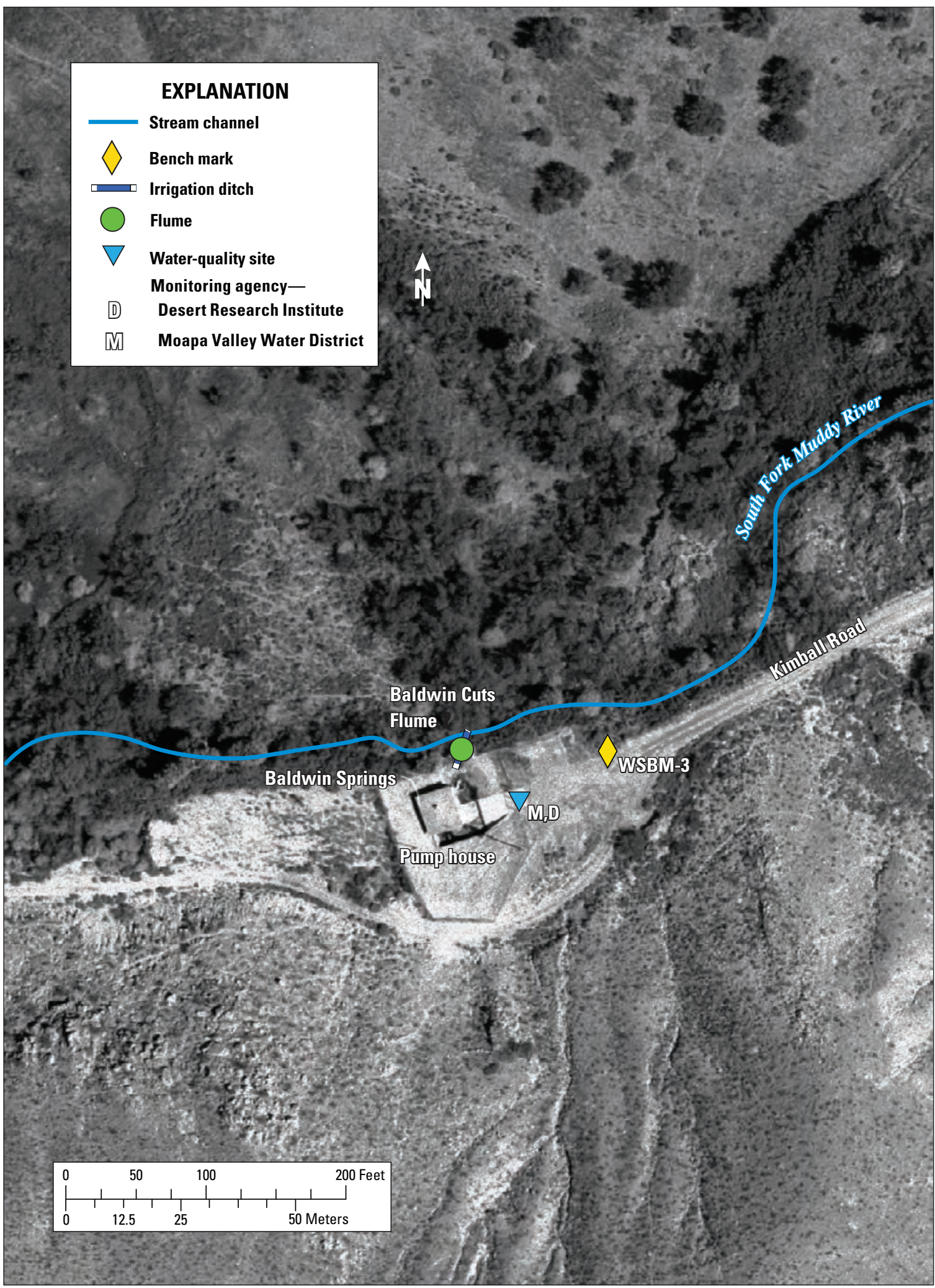

Figure B52. Location of Baldwin Springs, pump house, monitoring sites, and bench mark WSBM-3 in the Warm Springs area near Moapa, Nevada. 


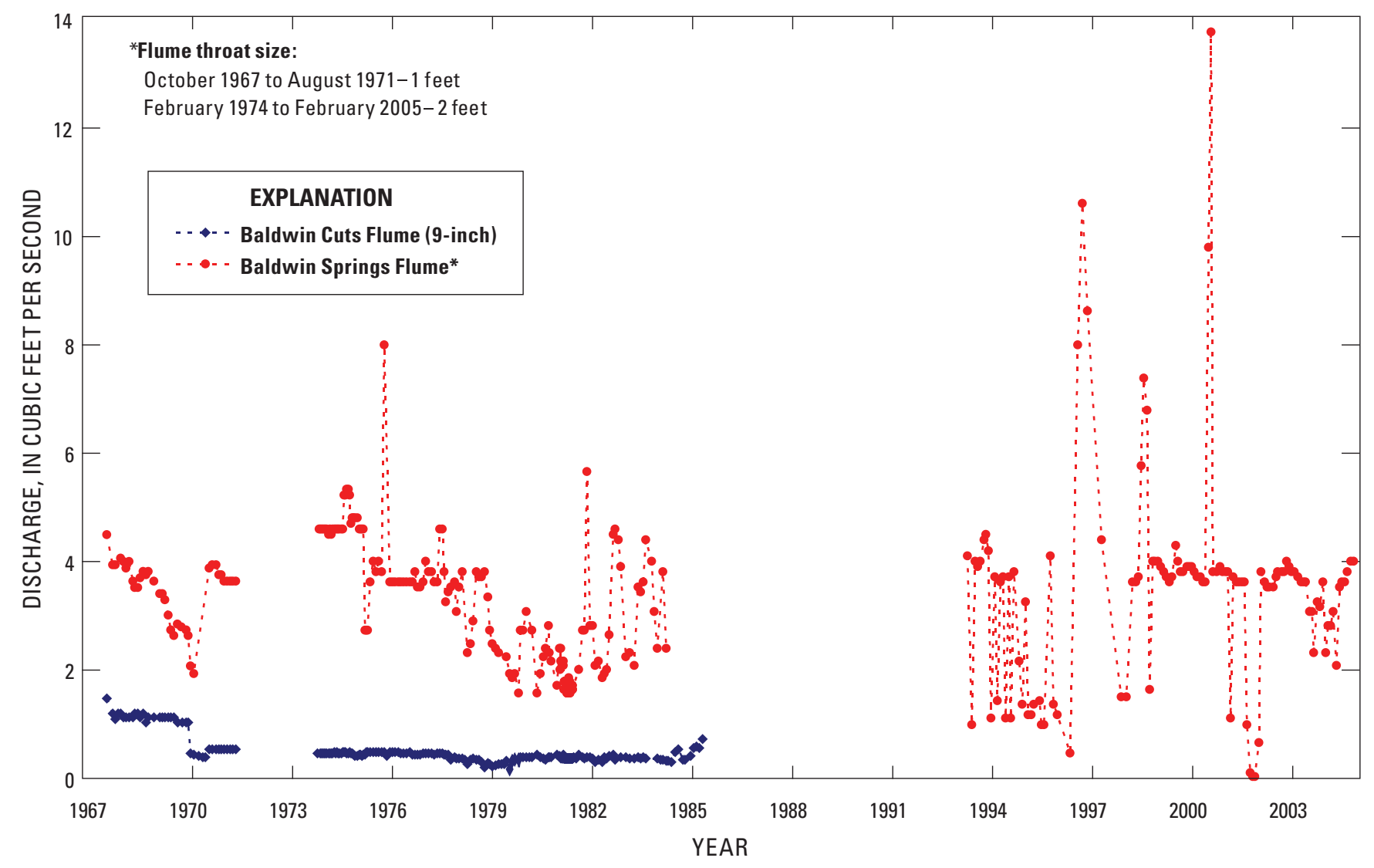

Figure B53. Instantaneous discharges computed from water-level measurements provided by Nevada Division of Water Resources for Baldwin Cuts and Baldwin Springs Flumes near Moapa, Nevada, 1967-2005. 
Table B40. Instantaneous discharges computed from water-level measurements for Baldwin Cuts Flume near Moapa, Nevada, $1967-85$.

Table B40 data are available in an Excel data base for download at URL: http://pubs.water.usgs.gov/ofr2006-1311. 


\section{Baldwin Springs Flume near Moapa, Nevada}

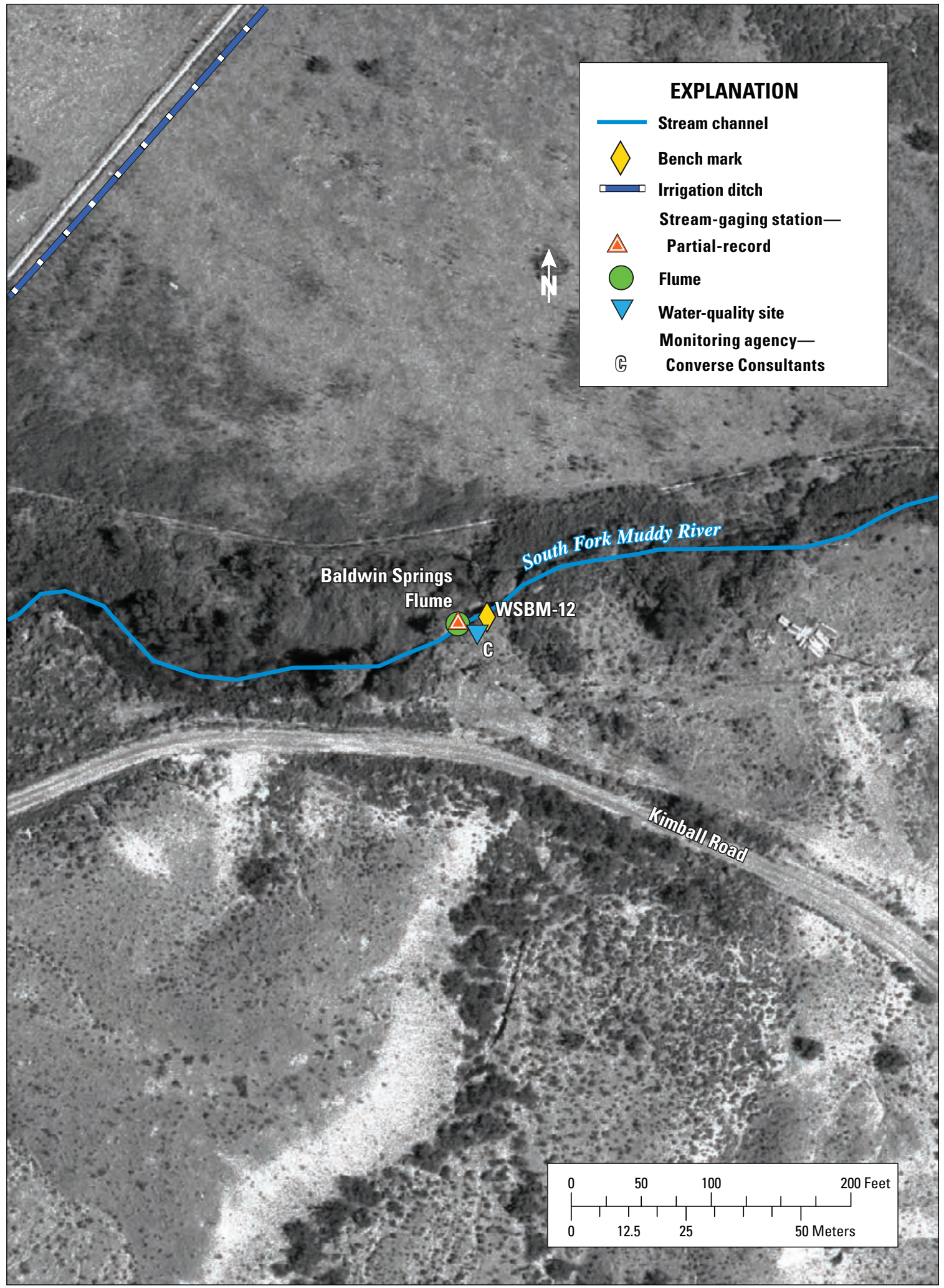

Figure B54. Location of Baldwin Springs Flume and bench mark WSBM-12 in the Warm Springs area near Moapa, Nevada. 
Table B41. Water levels and computed instantaneous discharges for partial-record stream-gaging station 09415875 Baldwin Springs Flume near Moapa, Nevada, 1967-2005.

Table B41 data are available in an Excel data base for download at URL: http://pubs.water.usgs.gov/ofr2006-1311. 


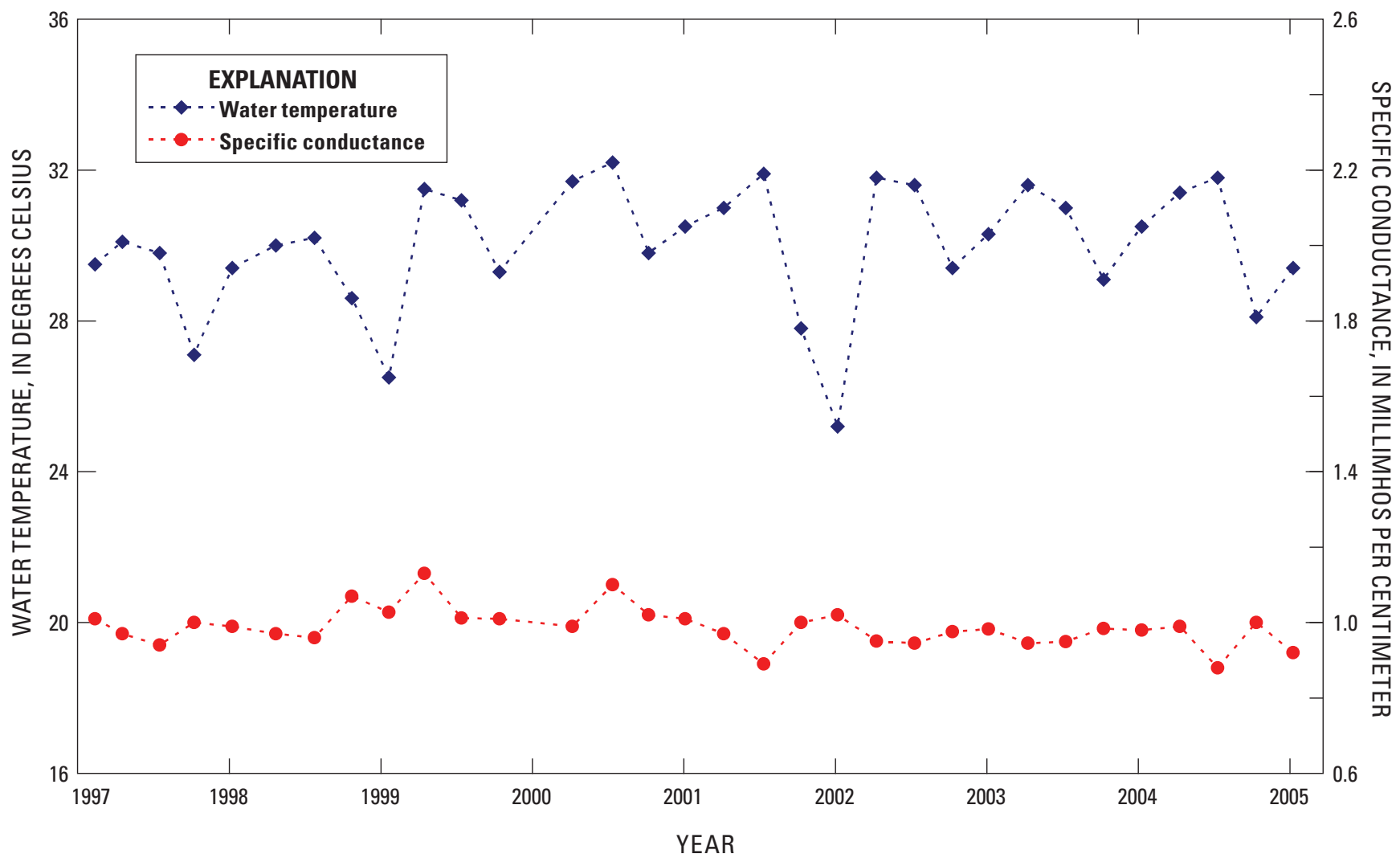

Figure B55. Water-temperature and specific-conductance measurements provided by Converse Consultants for Baldwin Springs Flume near Moapa, Nevada, 1997-2005. 
Table B42. Water-temperature and specific-conductance measurements provided by Converse Consultants for Baldwin Springs Flume near Moapa, Nevada, 1997-2005.

Table B42 data are available in an Excel data base for download at URL: http://pubs.water.usgs.gov/ofr2006-1311. 


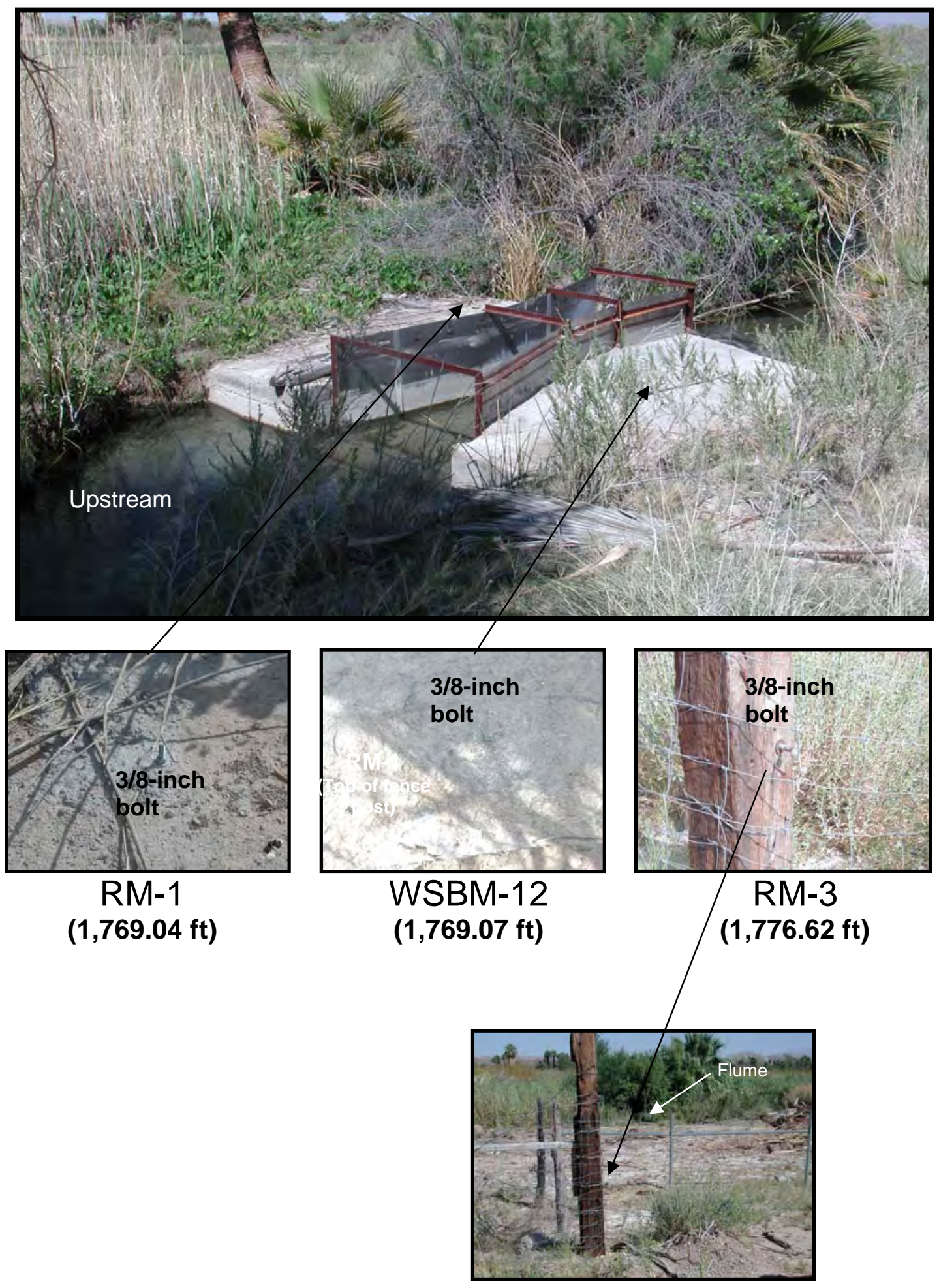

\section{Swimming pool upstream of $\mathrm{M}-20$}

Figure B56. Location of bench mark WSBM-12 and reference marks RM-1 and RM-3 for Baldwin Springs Flume in the Warm Springs area near Moapa, Nevada. Photographed June 2, 2004 by D. Beck. Elevation of bench and reference marks in feet above NAVD 88. 
Water-Quality Sites at Baldwin Spring Pump House near Moapa, Nevada 
Table B43. Water-quality data provided by the Moapa Valley Water District for pump house at Baldwin Springs near Moapa, Nevada, 1997-2004.

Table B43 data are available in an Excel data base for download at URL: http://pubs.water.usgs.gov/ofr2006-1311. 
Table B44. Water-quality data provided by the Desert Research Institute for pump house at Baldwin Springs near Moapa, Nevada, January 12 and May 18, 2004.

Table B44 data are available in an Excel data base for download at URL: http://pubs.water.usgs.gov/ofr2006-1311. 
162 Water-Surface Elevations, Discharge, and Water-Quality Data in the Warm Springs Area near Moapa, Nevada

This page left intentionally blank. 


\section{Cardy Lamb Springs}

The following sites are included within this section:

Baldwin House Spring \#1 (South) Flume (1967-80)

Baldwin House Spring \#2 (North) Flume (1967-80)

364327114430801 Muddy River Springs 10 (1986-2004)

Water-Quality Site (S-15) at Cardy Lamb Pond (1997-2005) 


\section{Cardy Lamb Springs near Moapa, Nevada}

Cardy Lamb Springs is about 0.1 mi east of Warm Springs Road and about 0.8 mi west-northwest of the L.D.S. Recreation Area (fig. 2). Discharge from this area generally trends to the southeast, but past agricultural and recreational developments in the area have modified or filled any preexisting natural drainage channels. An intricate network of concrete irrigation ditches installed during the 1950s and 1960s distributed most of the flow from the springs onto agricultural fields to the east (fig. 2). Sometime during 1980, a swimming pond and a bathhouse were constructed in the area in an attempt to develop a recreational facility (fig. B57). The pond was constructed over one of the spring discharge areas and a drainage pipe was installed at the northeast wall to allow the pond to drain into the irrigation drainage network (fig. B57). Although the recreational area never materialized, the pond is still used today by the current owners to irrigate fields to the east for livestock grazing.

On October 11, 1967, two 6-inch Parshall flumes (Baldwin House Spring \#1- South and Baldwin House Spring \#2-North) were installed by the Nevada Division of Water Resources (NDWR) as part of a program to monitor spring discharges within the Warm Springs area. The exact location of the two flumes is unknown, but they are believed to have been located between the pond and the irrigation ditch to the east (fig. B57). Data provided by NDWR show that waterlevel measurements for flumes \#1 and \#2 generally were made monthly from October 1967 to May 1980 and October 1967 to April 1980, respectively, except during September 1971 to January 1974. Since the last measurement at both sites coincides with the installation date of the pond, the flumes are believed to have been removed at that time. Because only water-level measurements were provided by NDWR, discharge rates were computed using a standard equation for the 6-inch Parshall flumes (Leupold and Stevens, 1987). Plots of the computed discharges for both flumes from October 1967 to May 1980 are shown in figure B58. Complete listings of the water-level measurements and computed discharges for Spring \#1 and Spring \#2 are given in tables B45 and B46, respectively.

The partial-record station at Muddy River Springs 10 (M-10) was established by the U.S. Geological Survey (USGS) on January 28, 1986 and is located about $250 \mathrm{ft}$ east of the swimming pond (fig. B57). The measurement site is inside an old concrete irrigation ditch about $2 \mathrm{ft}$ downstream from a small concrete culvert. Most of the flow at Muddy River Springs 10 originates from flow within the swimming pond that discharges through the drainage pipe. Water exiting the drainage pipe flows into a small pond approximately $10 \mathrm{ft}$ upstream of the concrete culvert and merges with flows from small springs to the southwest. Periodic discharge measurements have been made by the USGS since January 1986. Discharge measurements for the period of record are plotted in figure B59 and listed in table B47. Photographs of the bench mark, reference points, and selected reference marks established for the Muddy River Springs 10 monitoring site on June 3, 2004, are shown in figure B60.

In April 1997, Converse Consultants, on contract with Nevada Power Company, began quarterly field measurements of water temperature and specific conductance at site S15 (fig. B57) at the south end of the swimming pond. Measurements were compiled through March 2005 and are plotted in figure B61 and listed in table B48. 


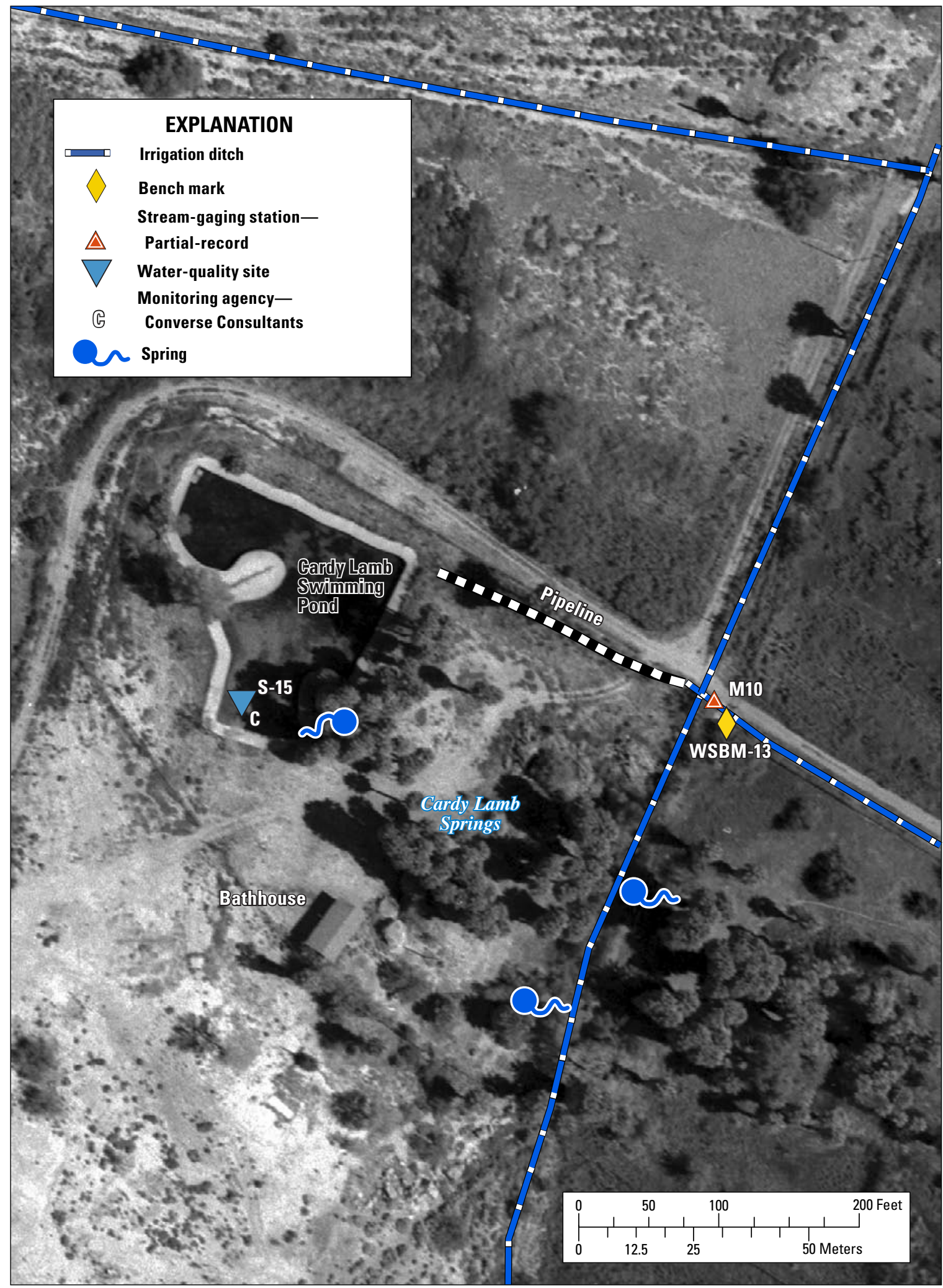

Figure B57. Location of Cardy Lamb Springs swimming pond, bench mark WSBM-13, and monitoring sites in the Warm Springs area near Moapa, Nevada. 


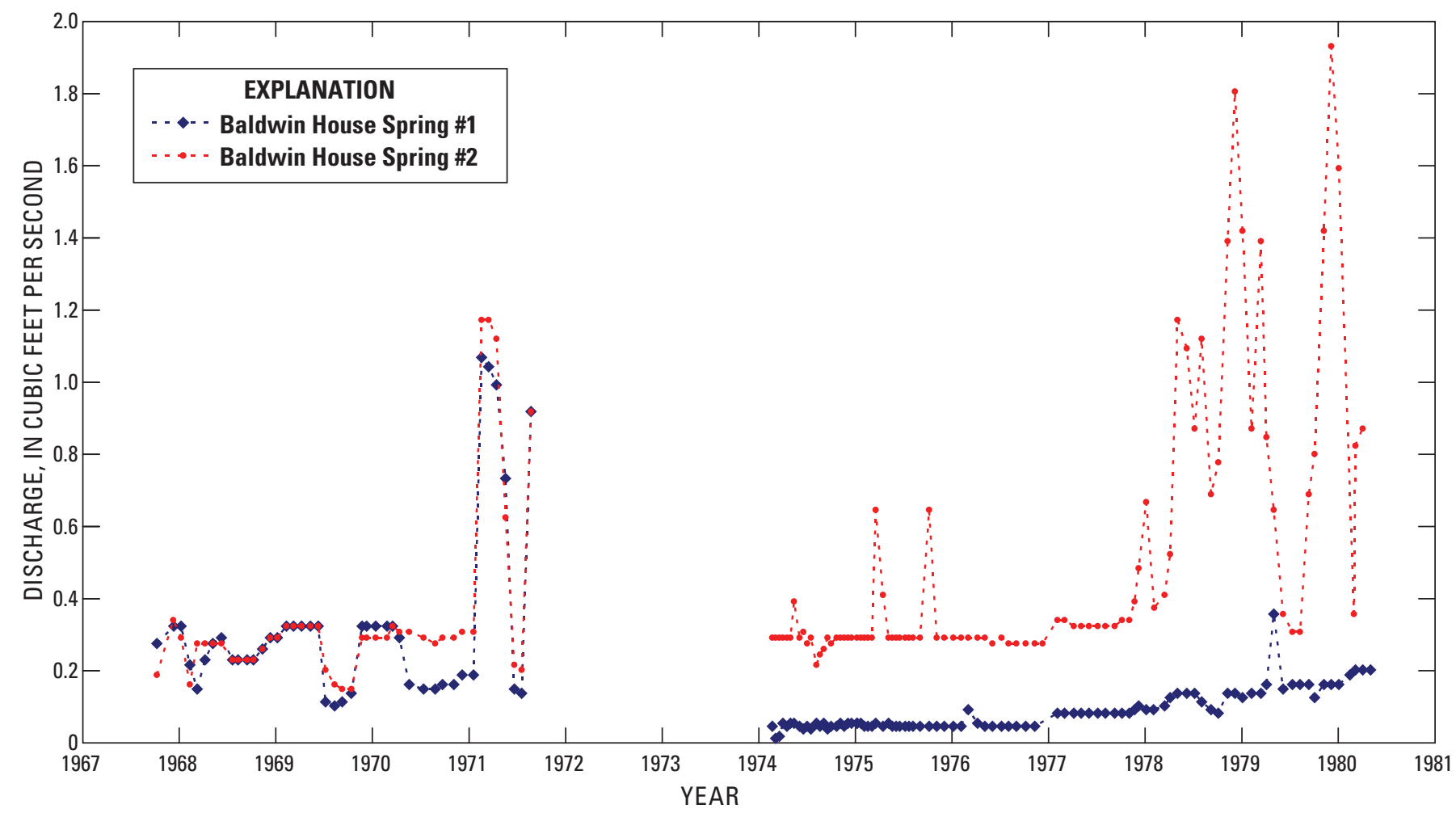

Figure B58. Instantaneous discharges for Baldwin House Springs \#1 and \#2 flumes at Cardy Lamb Springs near Moapa, Nevada, 1967-80. Data provided by Nevada Division of Water Resources. 
Baldwin House Spring \#1 (South) Flume near Moapa, Nevada 
Table B45. Water levels and computed instantaneous discharges for Baldwin House Spring \#1 (South) Flume at Cardy Lamb Springs near Moapa, Nevada, 1967-80.

Table B45 data are available in an Excel data base for download at URL: http://pubs.water.usgs.gov/ofr2006-1311. 
Baldwin House Spring \#2 (North) Flume near Moapa, Nevada 
Table B46. Water levels and computed instantaneous discharges for Baldwin House Spring \#2 (Nouth) Flume at Cardy Lamb Springs near Moapa, Nevada, 1967-80.

Table B46 data are available in an Excel data base for download at URL: http://pubs.water.usgs.gov/ofr2006-1311. 


\section{Muddy River Springs 10 (M-10) near Moapa, Nevada}

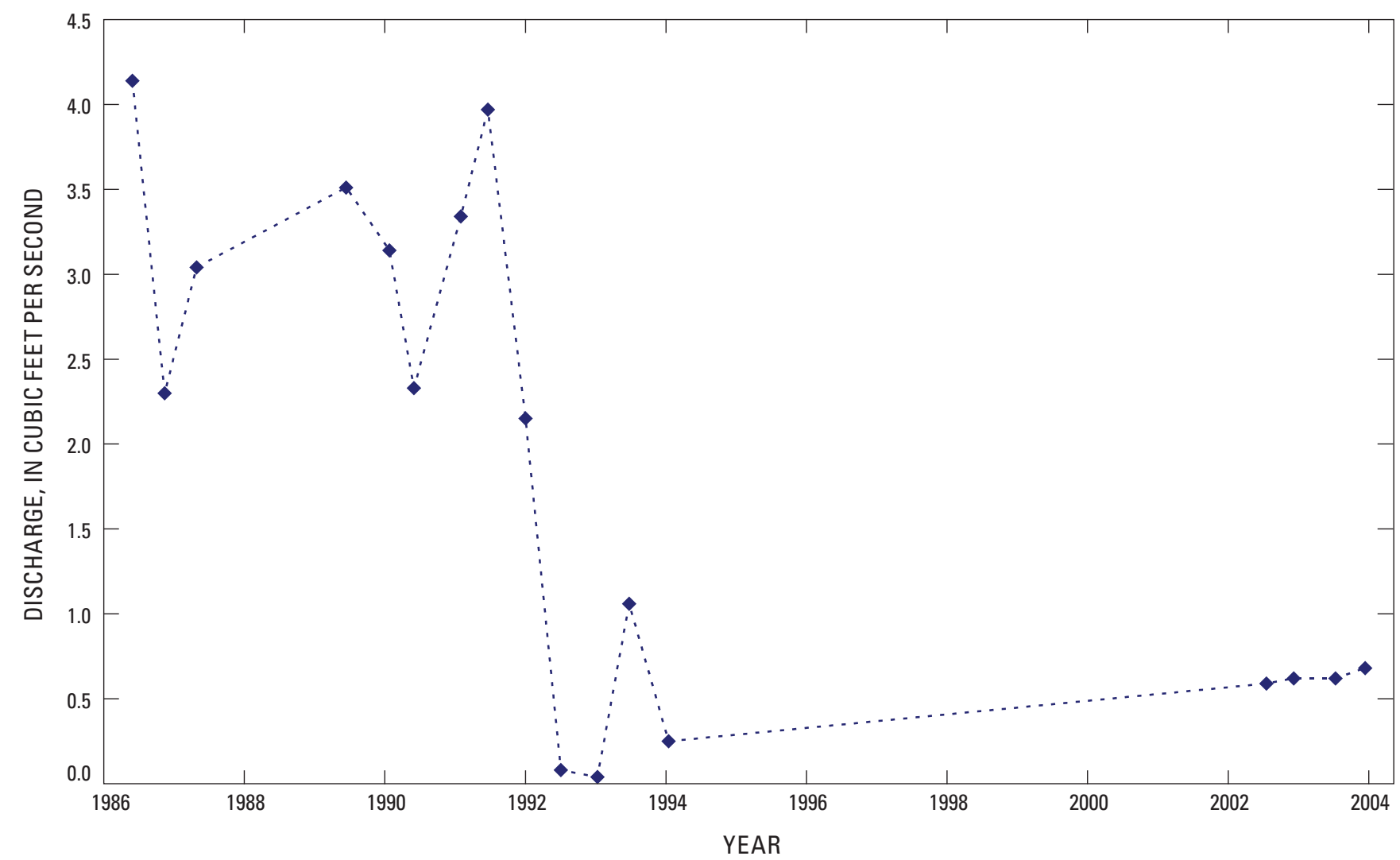

Figure B59. Periodic discharge measurements for partial-record stream-gaging station 364327114430801 Muddy River Springs 10 (M-10) at Cardy Lamb Springs near Moapa, Nevada, 1986-2004. 
172 Water-Surface Elevations, Discharge, and Water-Quality Data in the Warm Springs Area near Moapa, Nevada

Table B47. Periodic discharge measurements for partial-record stream-gaging station 364327114430801 Muddy River Springs 10 (M-10) at Cardy Lamb Springs near Moapa, Nevada, 1986-2004.

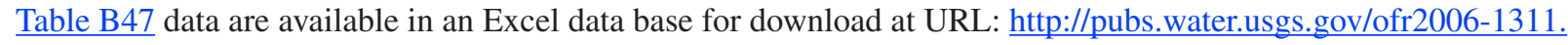




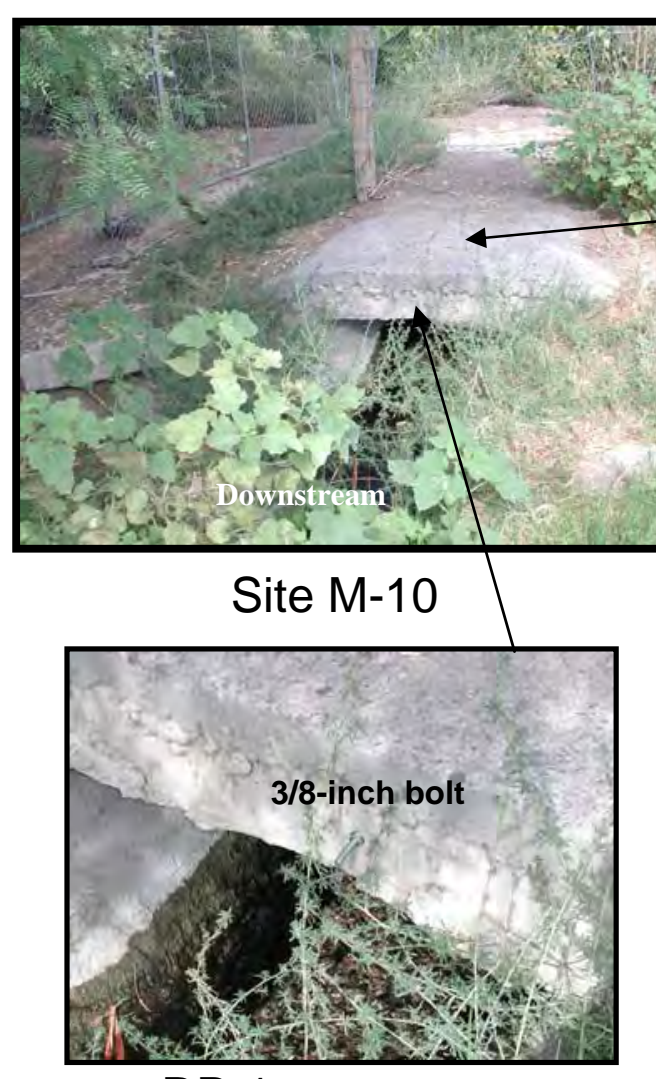

RP-1 (1,798.38 ft)

(Tape down point to measure water level)
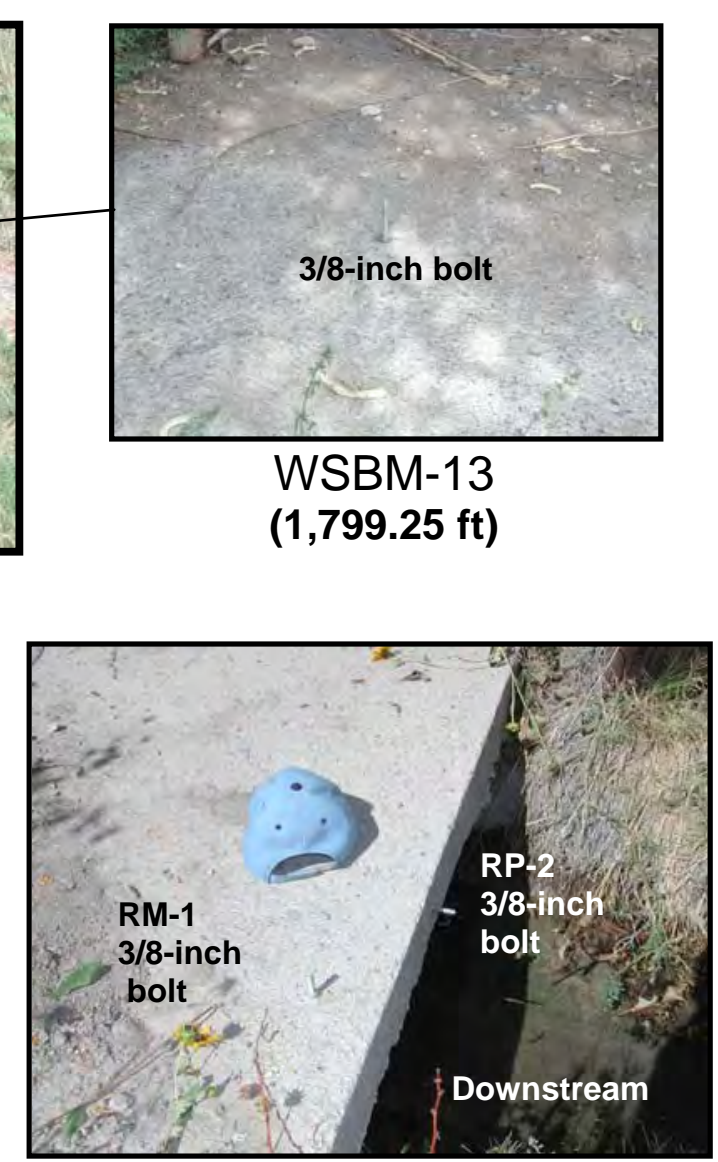

RP-2 (1,799.12 ft) and RM-1 $(1,799.46 \mathrm{ft})$ on North Ditch

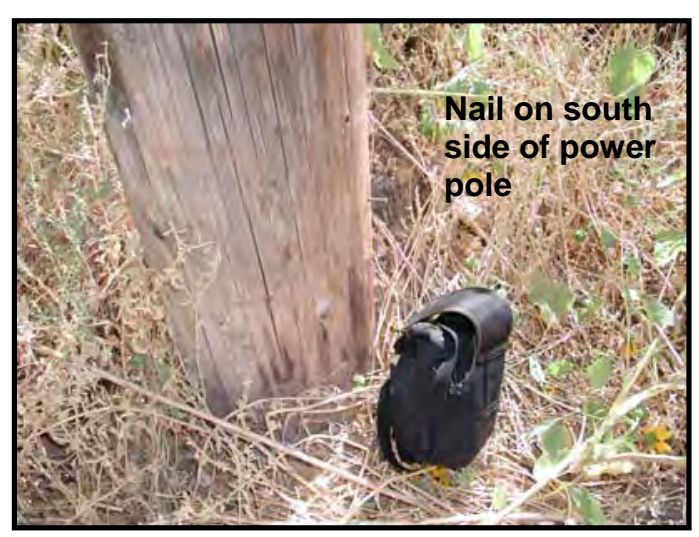

RM-2

$(1,800.51 \mathrm{ft})$

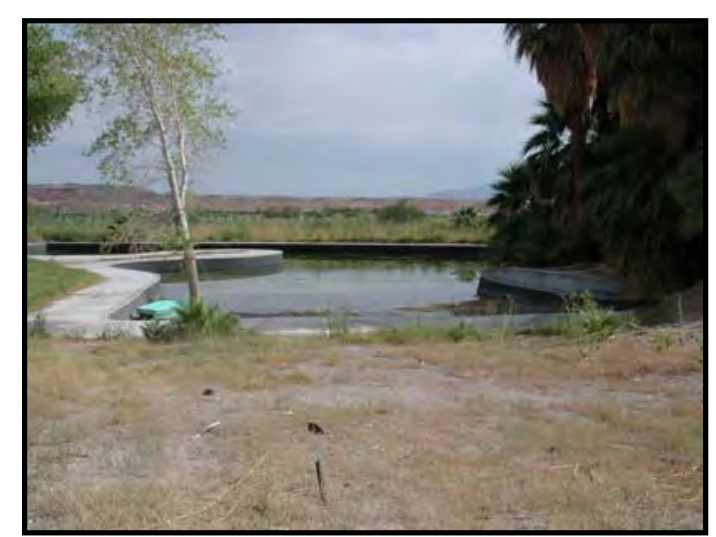

Cardy Lamb Swimming Pond upstream of M-10 channel

Figure B60. Location of bench mark WSBM-13, reference points RP-1 and RP-2, and reference marks RM-1 and RM-2 for partial-record station Muddy River Springs 10 (M-10) in the Warm Springs area near Moapa, Nevada. Photographed June 3, 2004 by D. Beck. Elevation of bench and reference marks in feet above NAVD 88. 


\section{Water-Quality Site at Cardy Lamb Pond near Moapa, Nevada}

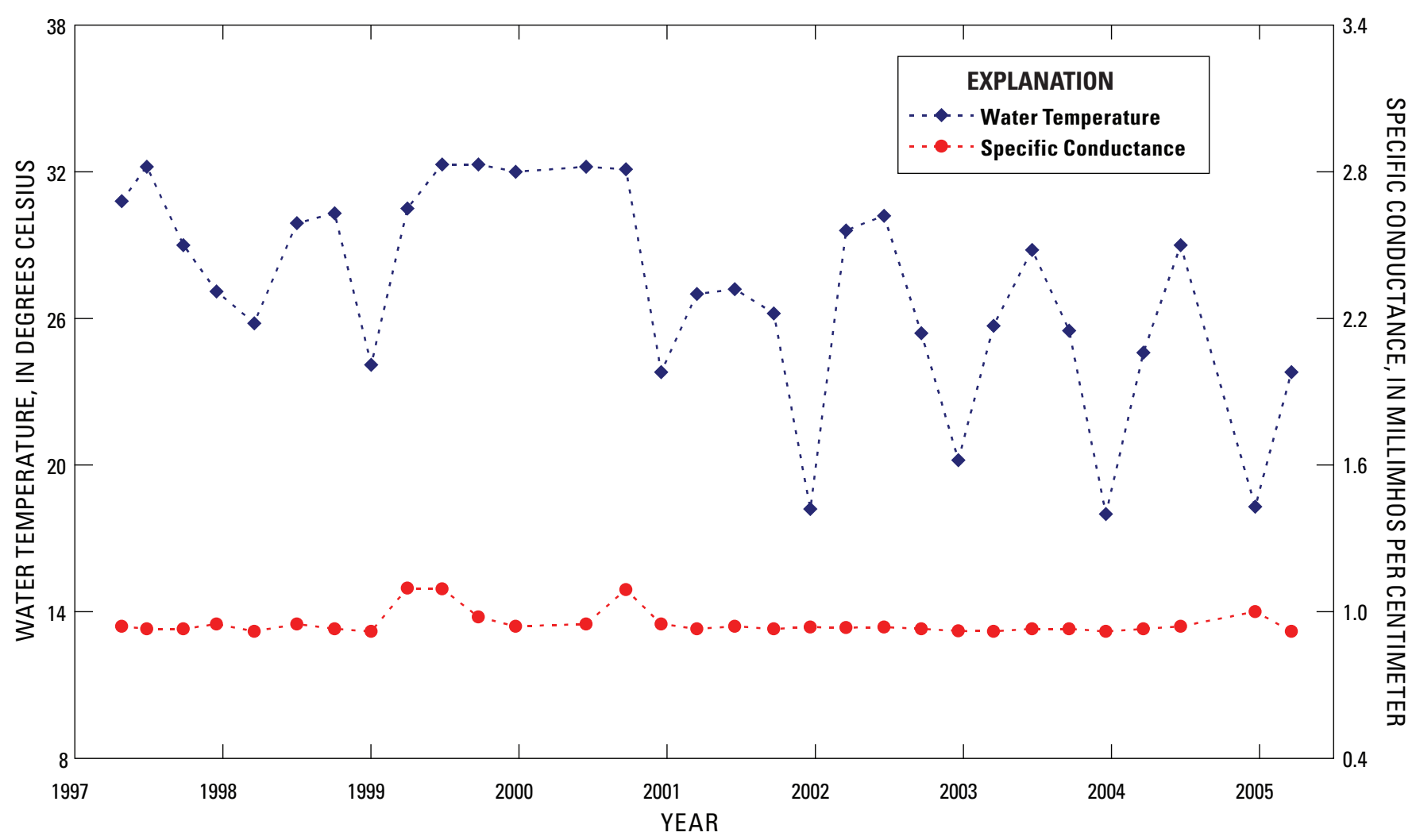

Figure B61. Water-temperature and specific-conductance measurements for site S15 at Cardy Lamb Springs near Moapa, Nevada, 1997-2005. Measurements provided by Converse Consultants. 
Table B48. Water-temperature and specific-conductance measurements provided by Converse Consultants for site S15 at Cardy Lamb Springs near Moapa, Nevada, 1997-2005.

Table B48 data are available in an Excel data base for download at URL: http://pubs.water.usgs.gov/ofr2006-1311. 
176 Water-Surface Elevations, Discharge, and Water-Quality Data in the Warm Springs Area near Moapa, Nevada

This page left intentionally blank. 


\section{Miscellaneous Sites}

The following sites are included within this section:

09415940 Apcar Stream at Pipeline Jones Flume near Moapa, Nevada (1967-2005)

09415927 Warm Springs Confluence at Iverson Flume near Moapa, Nevada (1967-2005)

Unnamed Springs at L.D.S. East well near Moapa, Nevada (2004)

Miscellaneous Water-Quality Sites (1997-2005) 


\section{Apcar Stream at Pipeline Jones Flume near Moapa, Nevada}

A 9-inch (in.) Parshall flume was installed on Apcar Stream on August 22, 1967, by the Nevada Division of Water Resources (NDWR). This flume is believed to have been located at or near the current flume site, which is about 670 $\mathrm{ft}$ north of Warm Springs Road (fig. B62) and about $0.6 \mathrm{mi}$ downstream of Apcar Springs (fig. 2). Although flow at the flume originates from Apcar Springs, additional water enters the stream channel from other springs and seeps downstream of the Warm Springs Road crossing. Below the flume, flow generally drains to the east and is tributary to Refuge Stream about 0.4 mi downstream.

Data provided by NDWR show that water-level measurements for the 9-in flume were made monthly from August 1967 until May 1969. Monthly measurements resumed on February 22, 1974, when a new, 2-ft Parshall flume was installed. Measurements ended on February 7 , 1985, and didn't resume until July 1993 when a new 3-ft Parshall flume was installed. Because only water-level measurements were provided by NDWR, discharge rates were computed using standard equations for the 9-in., 2-ft, and 3-ft Parshall flumes (Leupold and Stevens, 1987). A plot of the computed discharges from October 1967 to February 2005 is shown in figure B63. A complete listing of the water-level measurements and computed discharges is given in table B49.

Two discharge measurements were made at this site on February 7, 2001, as part of a multi-agency synoptic seepage run in the Warm Springs area. The discharges for the two measurements were averaged and the resulting value was plotted on figure B63. Discharge values and related information for the two measurements made during the seepage run are included in Appendix E.

On July 20, 2004, the U.S. Geological Survey installed a staff plate on the flume and established one bench mark and two reference marks at the site as part of this study. Photographs of the flume, bench mark, and reference marks are shown in figure B64. During the installation of the staff plate, backwater conditions were observed at the flume caused by a large palm tree that had fallen across the channel about $40 \mathrm{ft}$ downstream. Until the blockage is removed, computed discharges from water-level measurements will show erroneous higher rates of flow. 


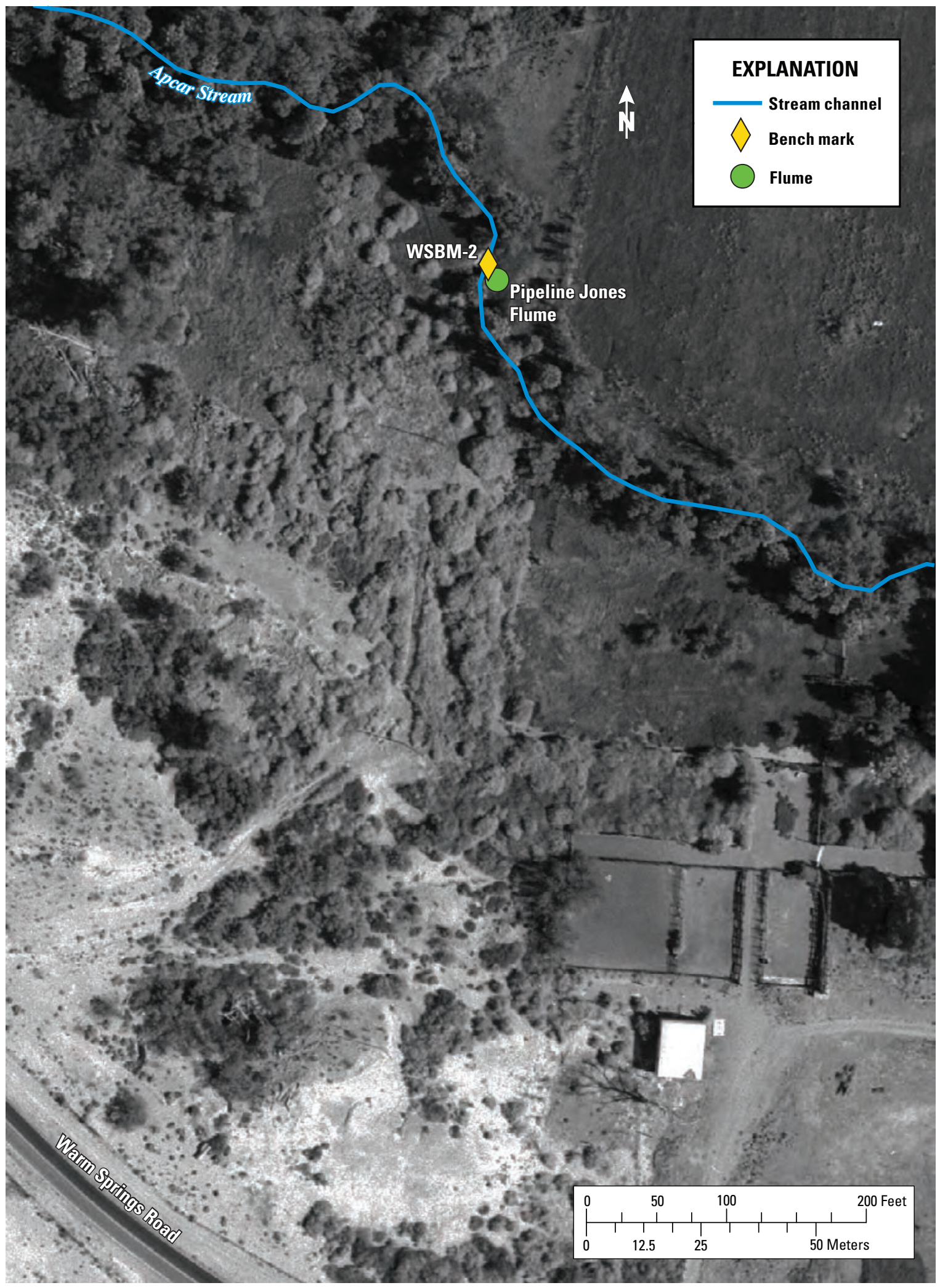

Figure B62. Location of Pipeline Jones Flume and bench Mark WSBM-2 in the Warm Springs area near Moapa, Nevada. 
Water-Surface Elevations, Discharge, and Water-Quality Data in the Warm Springs Area near Moapa, Nevada

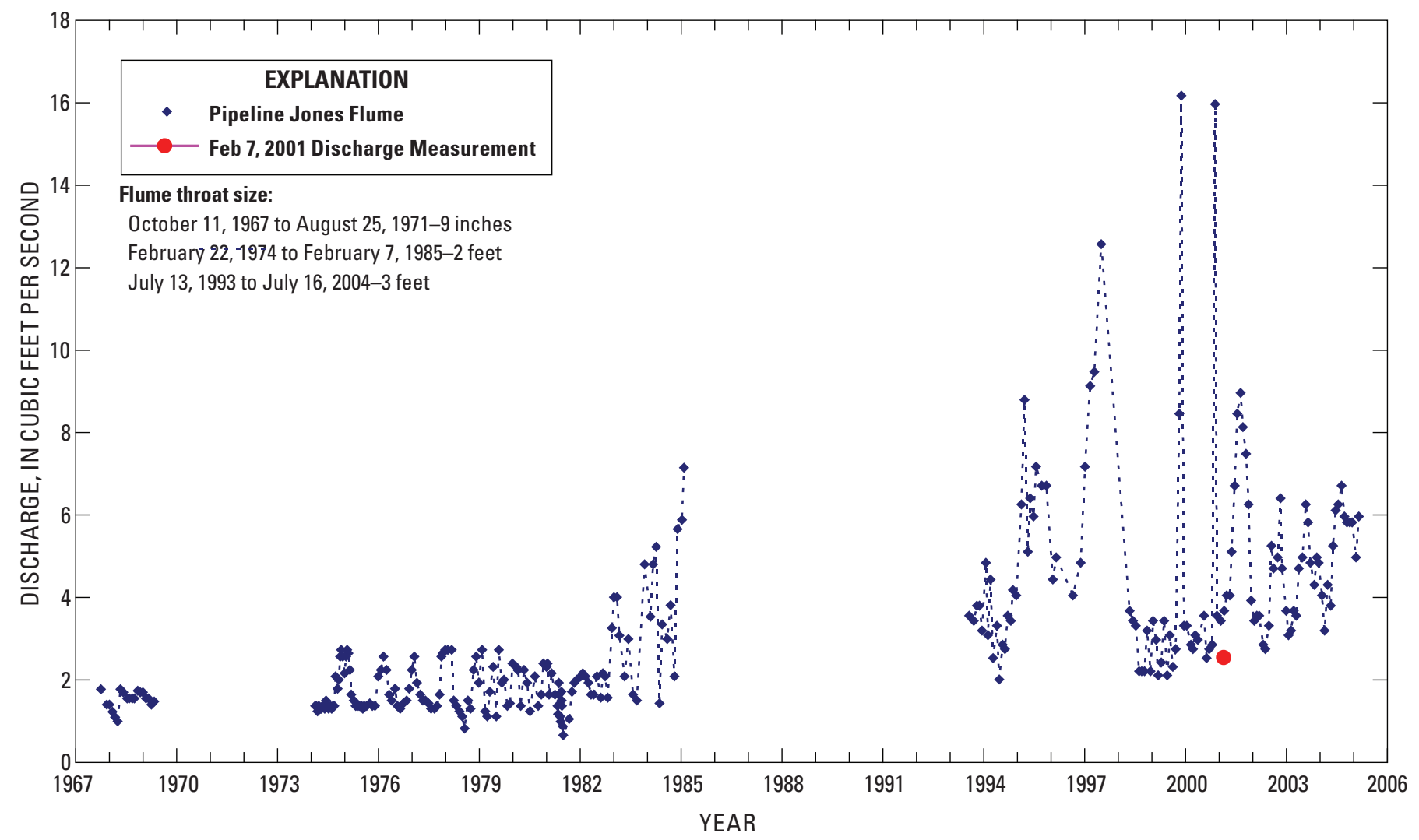

Figure B63. Instantaneous discharges compiled for 1967-2005, and discharge measurement made on February 7, 2001, for partial-record stream-gaging station 09415940 Apcar Stream at Pipeline Jones Flume near Moapa, Nevada. 
Table B49. Water levels and computed instantaneous discharges for partial-record stream-gaging station 09415940 Apcar Stream at Pipeline Jones Flume near Moapa, Nevada, 1967-2005.

[Data from Nevada Division of Water Resources.]

Table B49 data are available in an Excel data base for download at URL: http://pubs.water.usgs.gov/ofr2006-1311. 


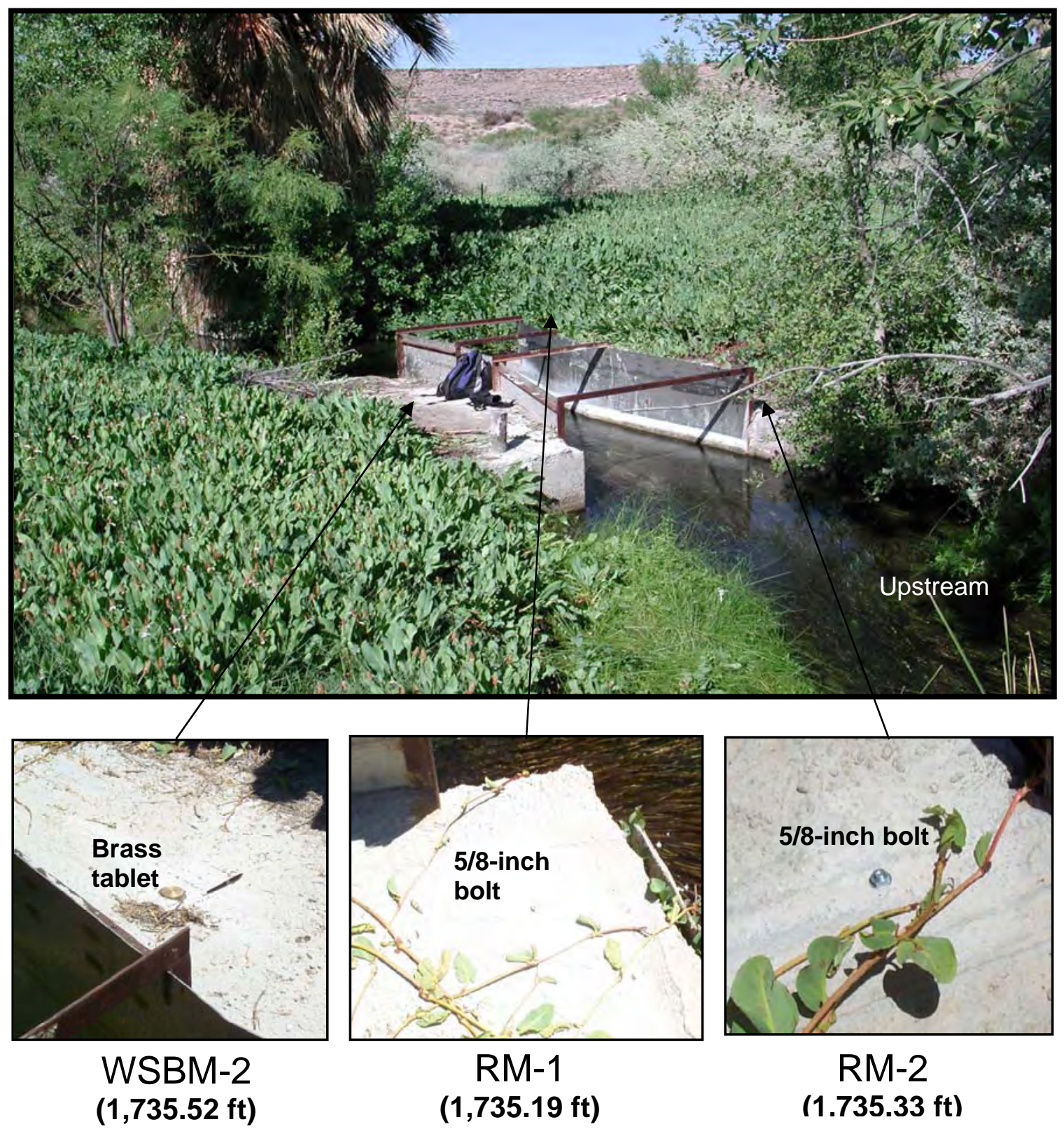

Figure B64. Location of bench mark WSBM-2 and reference marks RM-1 and RM-2 at partial-record streamgaging station 09415940 Apcar Stream at Pipeline Jones Fume near Moapa, Nevada. Photographed July 20, 2004 by D. Beck. Elevation of bench and reference marks in feet above NAVD 88. 


\section{Warm Springs Confluence at Iverson Flume near Moapa, Nevada}

A 1-foot (ft) Parshall flume was installed on Refuge Stream on October 11, 1967, by the Nevada Division of Water Resources (NDWR). The flume was located approximately 0.8 mi southeast of the L.D.S. Recreational Area and about $250 \mathrm{ft}$ north of Warm Springs Road (fig. B65). Flow at this flume is the combined discharges from the Plummer and Pederson Spring groups. Below the flume, flow generally drains to the northeast and is tributary to the Muddy River about 0.3 mi downstream. Flow from Apcar Stream enters Refuge Stream from the west about $800 \mathrm{ft}$ downstream from the flume.

Data provided by NDWR show that water-level measurements for the 1-ft Parshall flume generally were made monthly from October 1967 until August 1971. Monthly measurements resumed on February 24, 1974, when a new, 3-ft Parshall flume was installed. Measurements ended on November 19, 1987, and didn't resume until July 1993 when a new 3-ft Parshall flume was installed. The site is still visited monthly by NDWR. Because only water-level measurements were provided by NDWR, discharge rates were computed using standard equations for the $1-\mathrm{ft}$ and $3-\mathrm{ft}$ Parshall flumes (Leupold and Stevens, 1987). A plot of the computed discharges from October 1967 to February 2005 is shown in figure B66. A complete listing of the waterlevel measurements and computed discharges are given in table B50.

A continuous-stage recorder was installed at the flume by the U.S. Geological Survey on October 1, 2001, and maintained through September 30, 2004. From the time that the gage was installed, submerged flow conditions have been in effect owing to the growth of a large palm tree and other plants in the channel downstream from the flume. Discharge measurements are routinely made at the site and used to define the stage-discharge relation for the flume. Daily mean discharges computed for the period of record have been included for comparison on the plot in figure B66 and listed in table B51. Photographs of the current flume, bench mark, and a selected reference mark established for this gage on June 3, 2004, are shown in figure B67. 


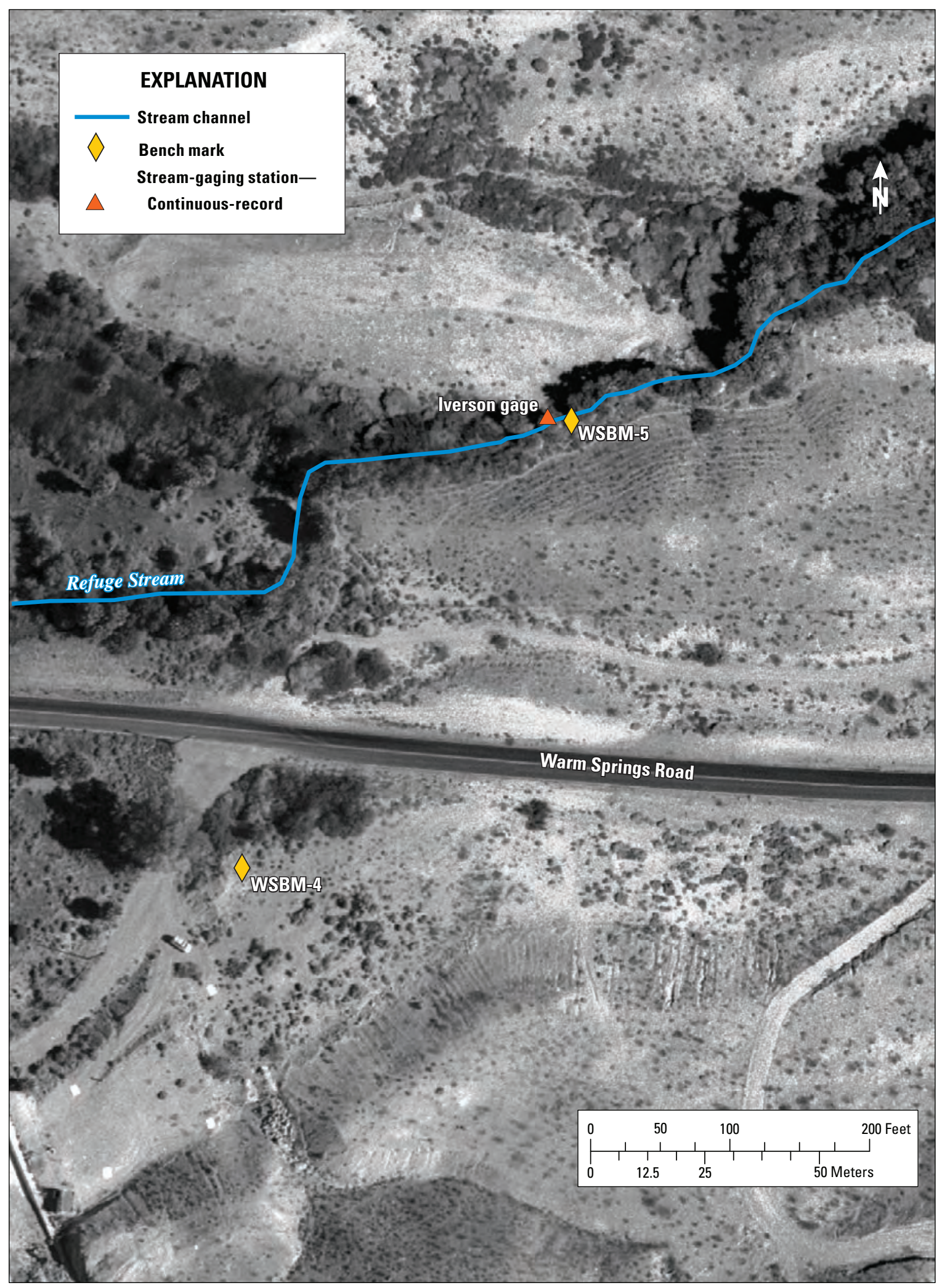

Figure B65. Location of continuous-record stream-gaging station 09415927 and bench marks, WSBM-4 and WSBM-5, Warm Springs Confluence at Iverson Flume near Moapa, Nevada. 


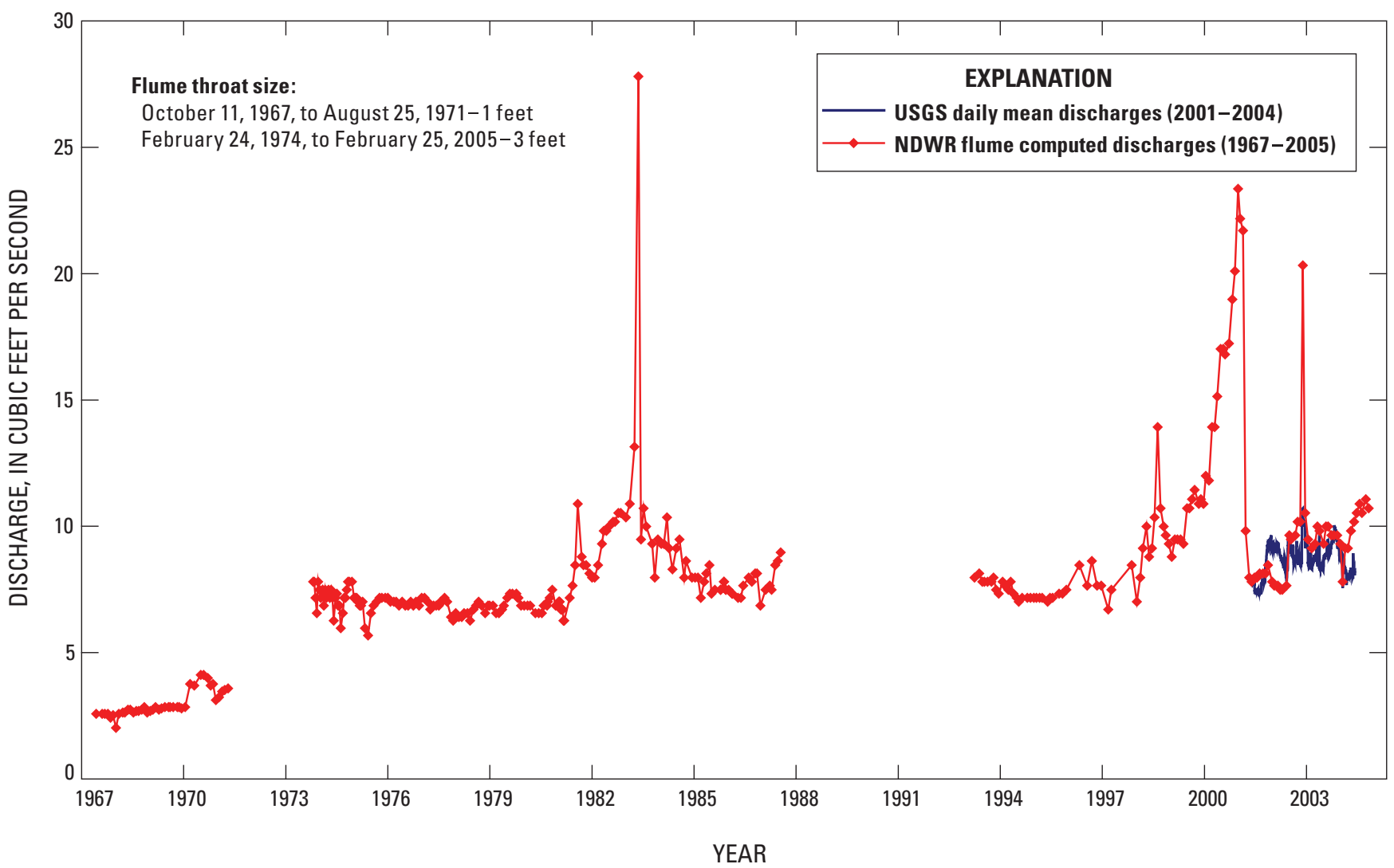

Figure B66. Instantaneous and daily mean discharges for continuous-record stream-gaging station 09415927 Warm Springs Confluence at Iverson Flume near Moapa, Nevada, 1967-2005. Data from U.S. Geological Survey (USGS) National Water Information System (NWIS) data base, accessed 2005 at http://waterdata.usgs.gov. Water level measurements used to compute discharges were provided by Nevada Division of Water Resources (NDWR). 
Table B50. Water levels and computed instantaneous discharges for continuous-record stream-gaging station 09415927 Warm Springs Confluence at Iverson Flume near Moapa, Nevada, 1967-2005.

[Water-level measurements provided by Nevada Division of Water Resources.]

$\underline{\text { Table B50 }}$ data are available in an Excel data base for download at URL: $\underline{\text { http://pubs.water.usgs.gov/ofr2006-1311. }}$ 
Table B51. Daily mean discharges for continuous-record stream-gaging station 09415927 Warm Springs Confluence at Iverson Flume near Moapa, Nevada, water years 2002-04.

[Data from U.S. Geological Survey (USGS) National Water Information System (NWIS) data base, accessed 2005 at http://waterdata.usgs.gov]

Table B51 data are available in an Excel data base for download at URL: http://pubs.water.usgs.gov/ofr2006-1311. 


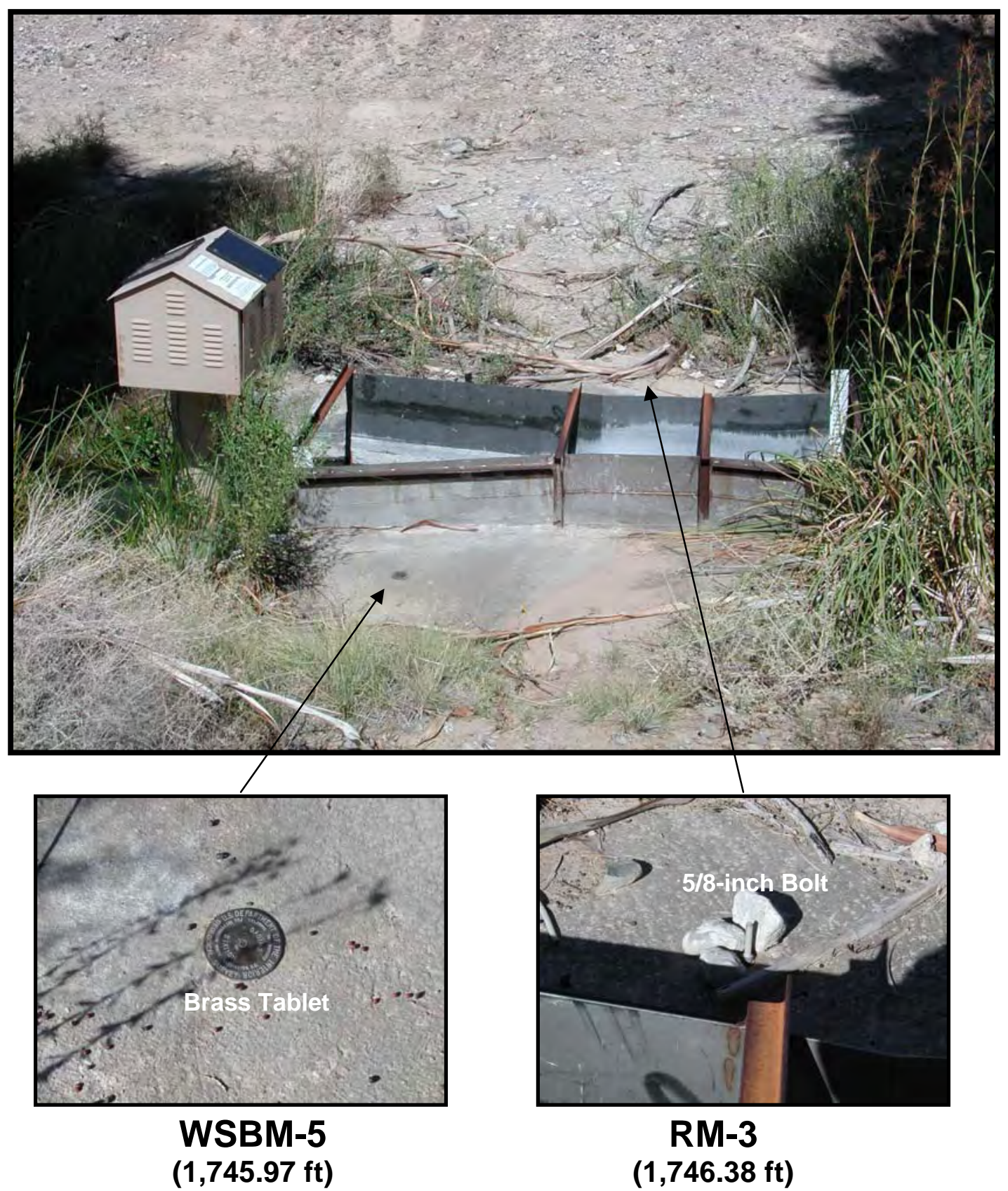

Figure B67. Location of bench mark WSBM-5 and reference mark RM-3 at continuous-record stream-gaging station 09415927 Warm Springs Confluence at Iverson Flume near Moapa, Nevada. Photographed June 3, 2004 by D. Beck. Elevation of bench and reference marks in feet above NAVD 88. 


\section{Unnamed Springs at L.D.S. East Well near Moapa, Nevada}

An unnamed group of springs is located just to the south and east of L.D.S. Well East adjacent to State Highway 168 in the north-central part of the Warm Springs area (figs. 2 and $\underline{B} 68)$. Discharge from the springs may have been perennial in the past; however, discharge is currently intermittent, occurring mainly during the winter when pumpage from the well and evapotranspiration rates are at their lowest. Flow from the area generally is to the southeast, but a network of irrigation ditches distributes flow to the east and south. During field reconnaissance of the Warm Springs area in February 2004, discharge from the springs was observed flowing into the Muddy River at two locations. The first site was about $100 \mathrm{ft}$ upstream of the confluence with Refuge Stream. The second site was about 0.3 mi downstream from the confluence with Refuge Stream.

On August 17, 2004, surface-water elevations at all U.S. Geological Survey monitoring sites within the Warm Springs area were measured. At this time, the unnamed springs were not discharging; therefore, the elevation of a small spring pool about $100 \mathrm{ft}$ to the east of L.D.S. Well East was measured using optical theodolite surveying techniques (Kennedy, 1988). Elevation for the water-surface measurement was determined using a bench mark (WSBM-10) established at the well by the Las Vegas Valley Water District (table 2). The surface-water elevation of the pond on August 17, 2004, is given in table 4. Photographs showing the location of the bench mark and measurement site are included in figure B69.

In April 1997, Converse Consultants, on contract with Nevada Power Company, initiated quarterly field measurements of water temperature and specific conductance at the unnamed spring area (fig, B68). Measurements were compiled through March 2005 and are plotted in figure B70 and listed in table B52. 


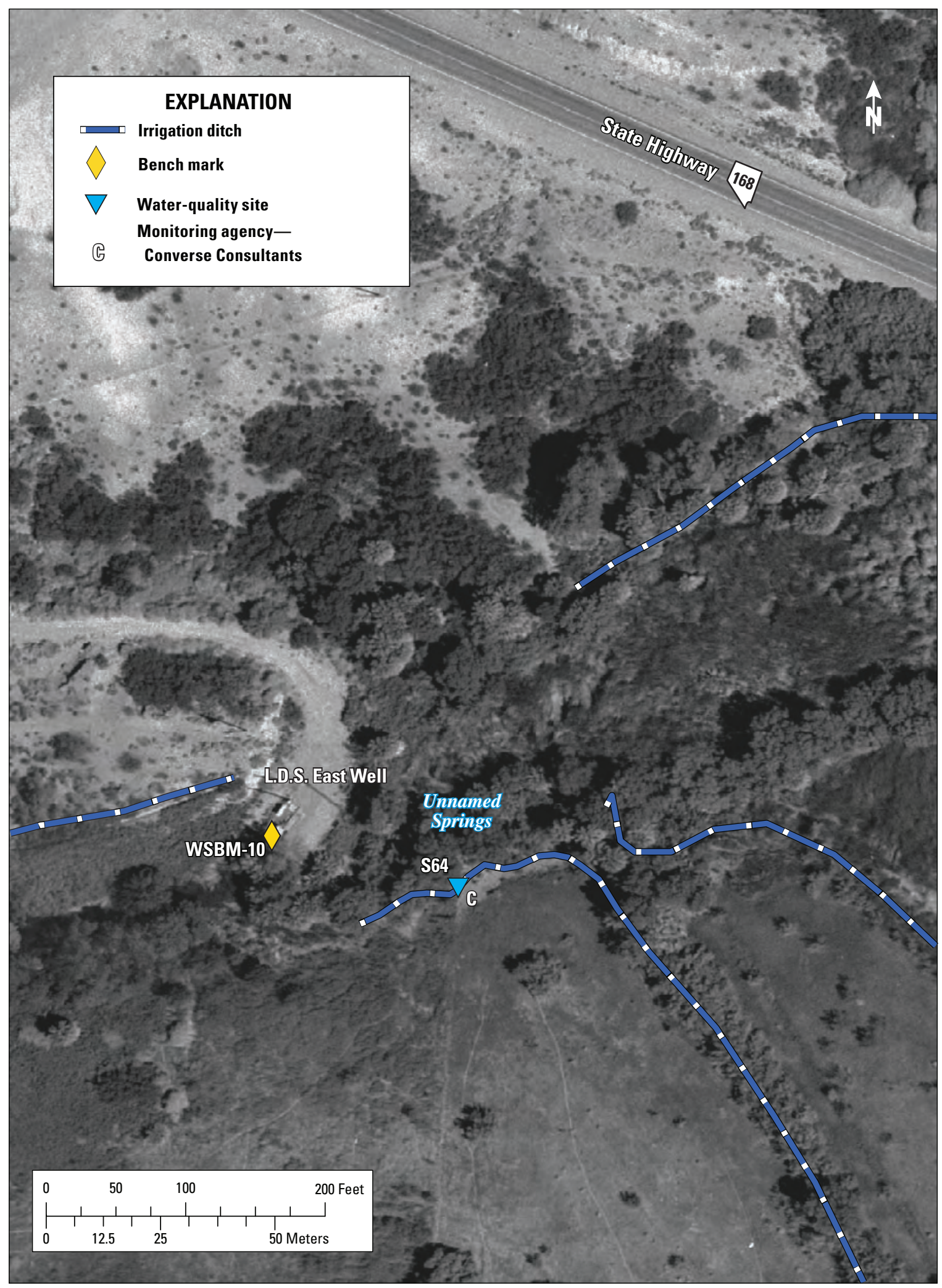

Figure B68. Location of unnamed springs near L.D.S. East well and bench mark WSBM-10 in the Warm Springs area near Moapa, Nevada. 

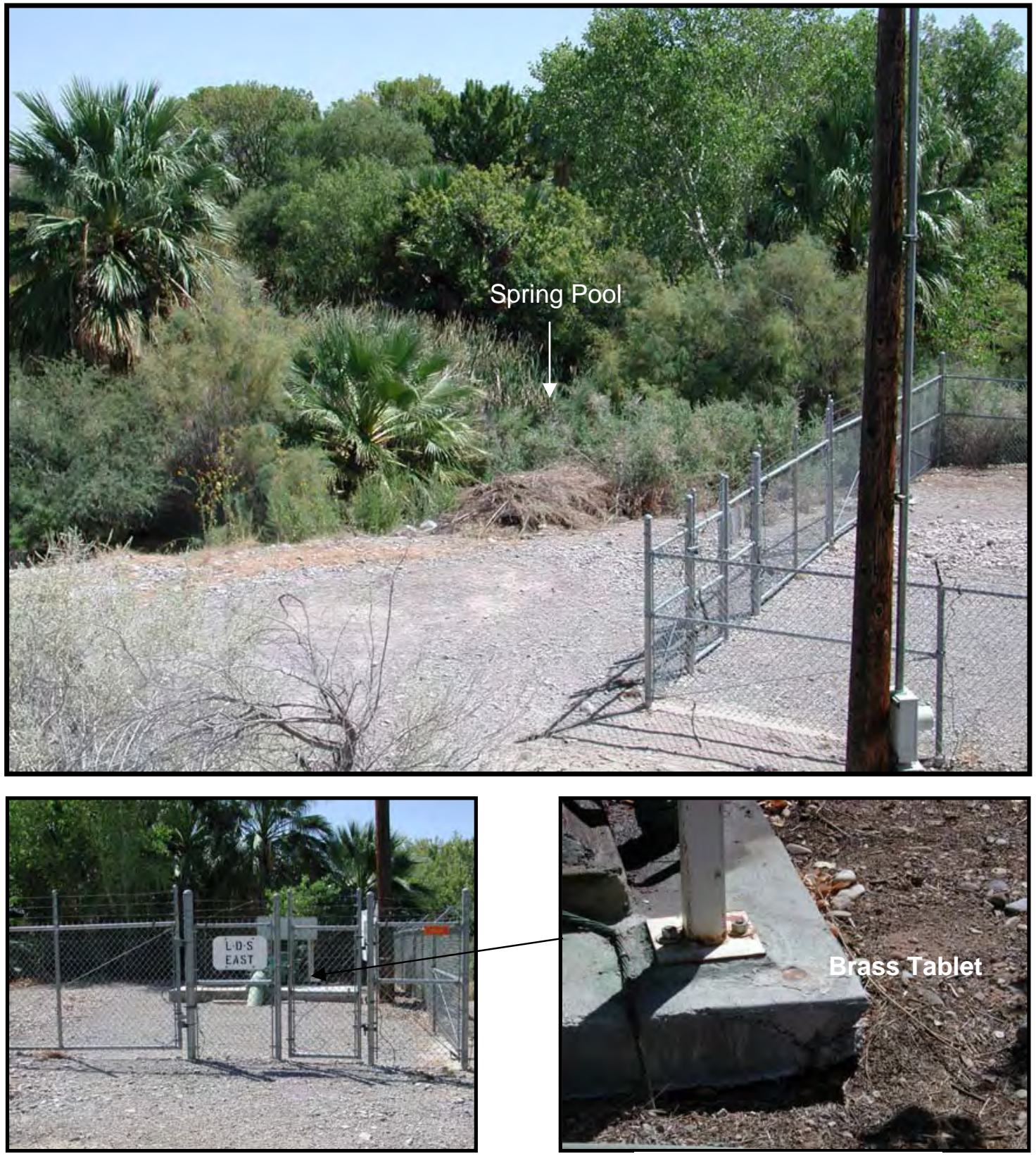

WSBM-10

$(1.752 .32 \mathrm{ft})$

Figure B69. Location of bench mark WSBM-10 at L.D.S. East well and spring-fed pool surveyed on August 17, 2004, at unnamed springs near Moapa, Nevada. Elevation of bench mark in feet above NAVD 88. 


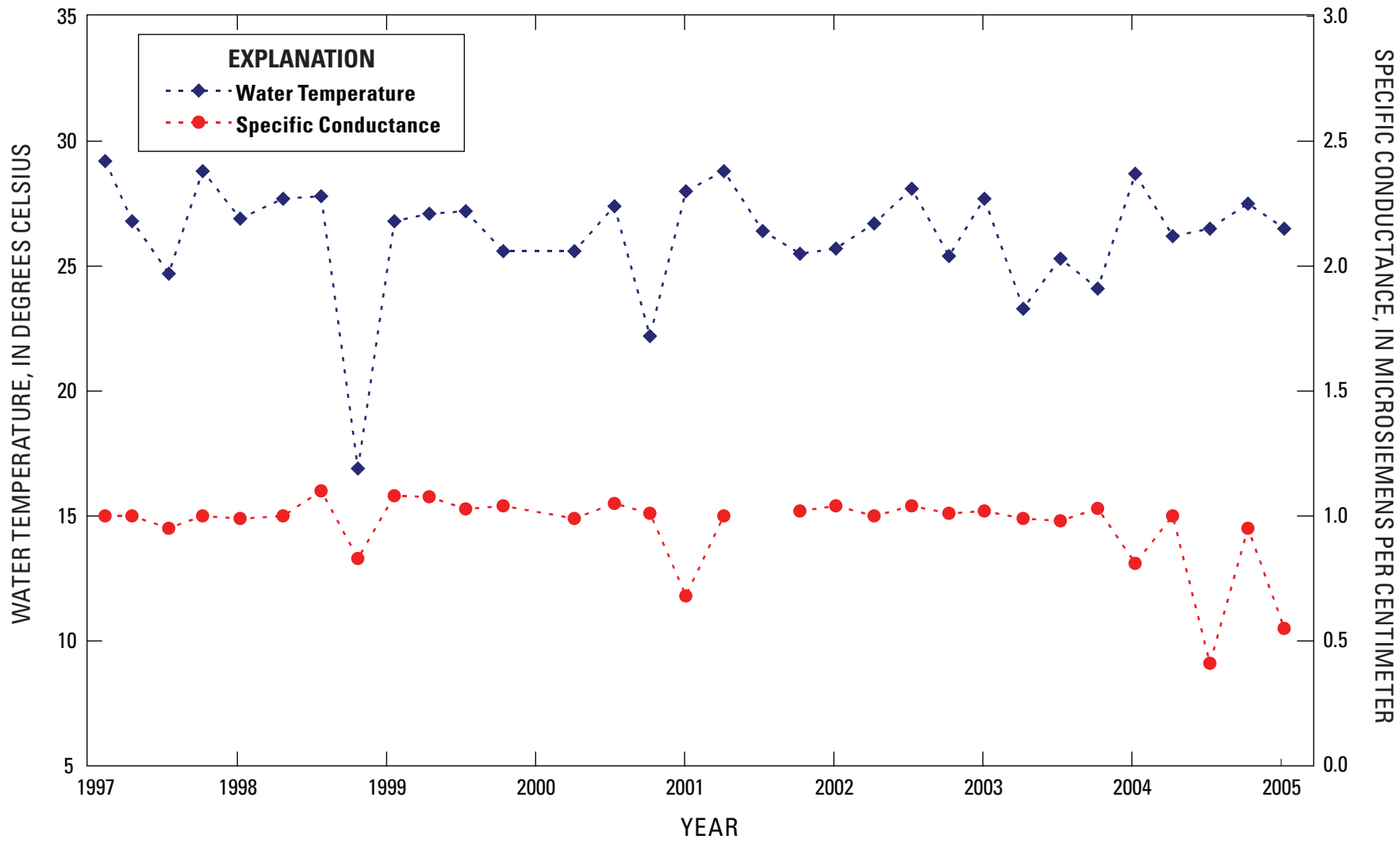

Figure B70. Water-temperature and specific-conductance measurements for spring pond at unnamed springs at L.D.S. East well near Moapa, Nevada, 1997-2005. Measurements provided by Converse Consultants. 
Table B52. Water-temperature and specific-conductance measurements by Converse Consultants for spring pond at unnamed springs at L.D.S. East well near Moapa, Nevada, 1997-2005.

Table B52 data are available in an Excel data base for download at URL: http://pubs.water.usgs.gov/ofr2006-1311. 


\section{Miscellaneous Water-Quality Sites in the Warm Springs area near Moapa, Nevada}

In April 1997, Converse Consultants, on contract with Nevada Power Company, began quarterly field measurements of water temperature and specific conductance at selected springs within the Warm Springs area. Most of the measurement sites are located at springs that are included as part of the major spring groups, such as Plummer, Pederson, Apcar, Muddy, and Cardy Lamb, and are discussed elsewhere in this report. Other measurement sites that are not part of the major spring groups include S6, S7a, and S65. The locations of these sites are shown in figure B71.

Water temperature and specific conductance data for the period of record for sites S6, S7a, and S65 are plotted in figures B72, B73, and B74 and listed in tables B53, B54, and B55, respectively. 


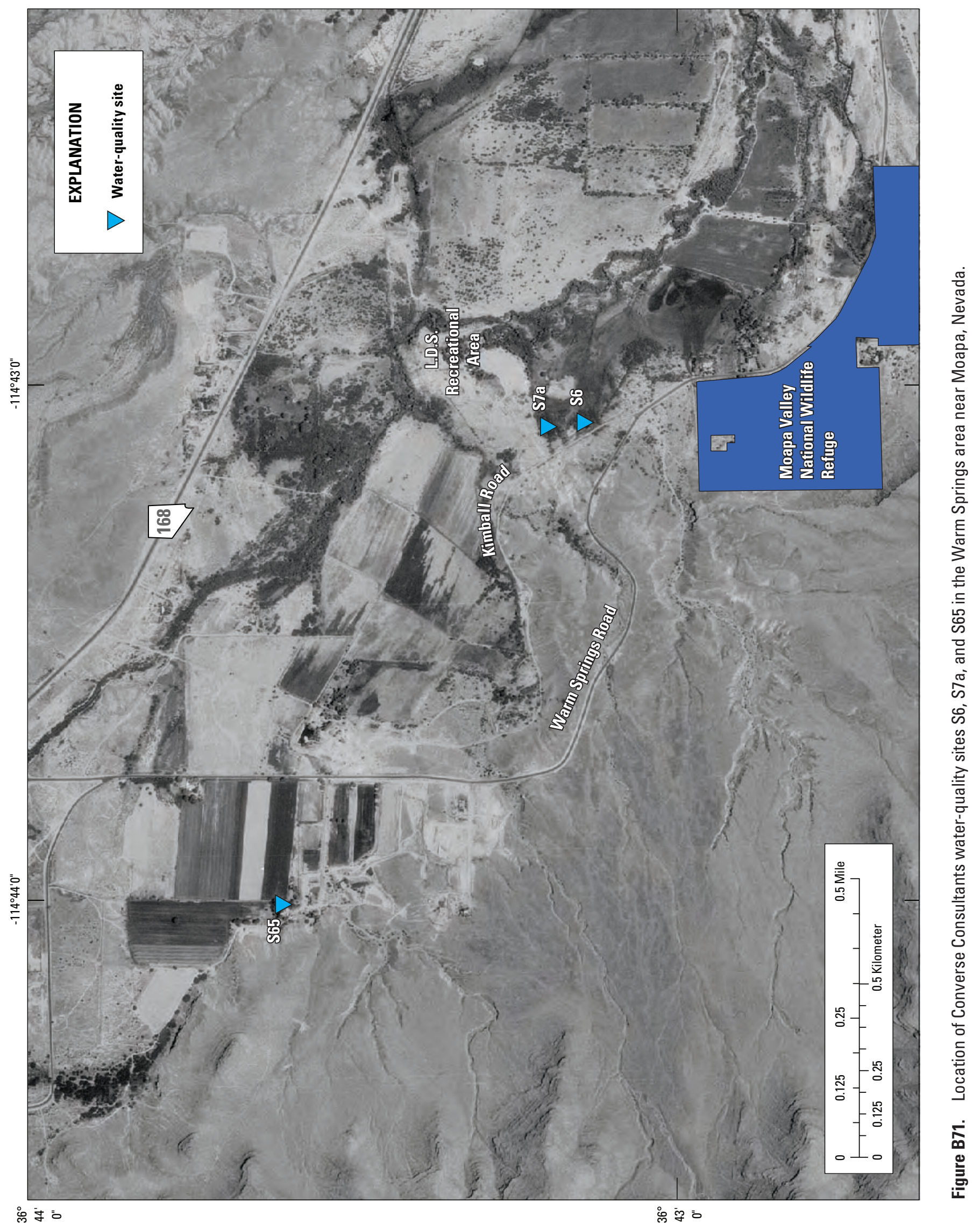




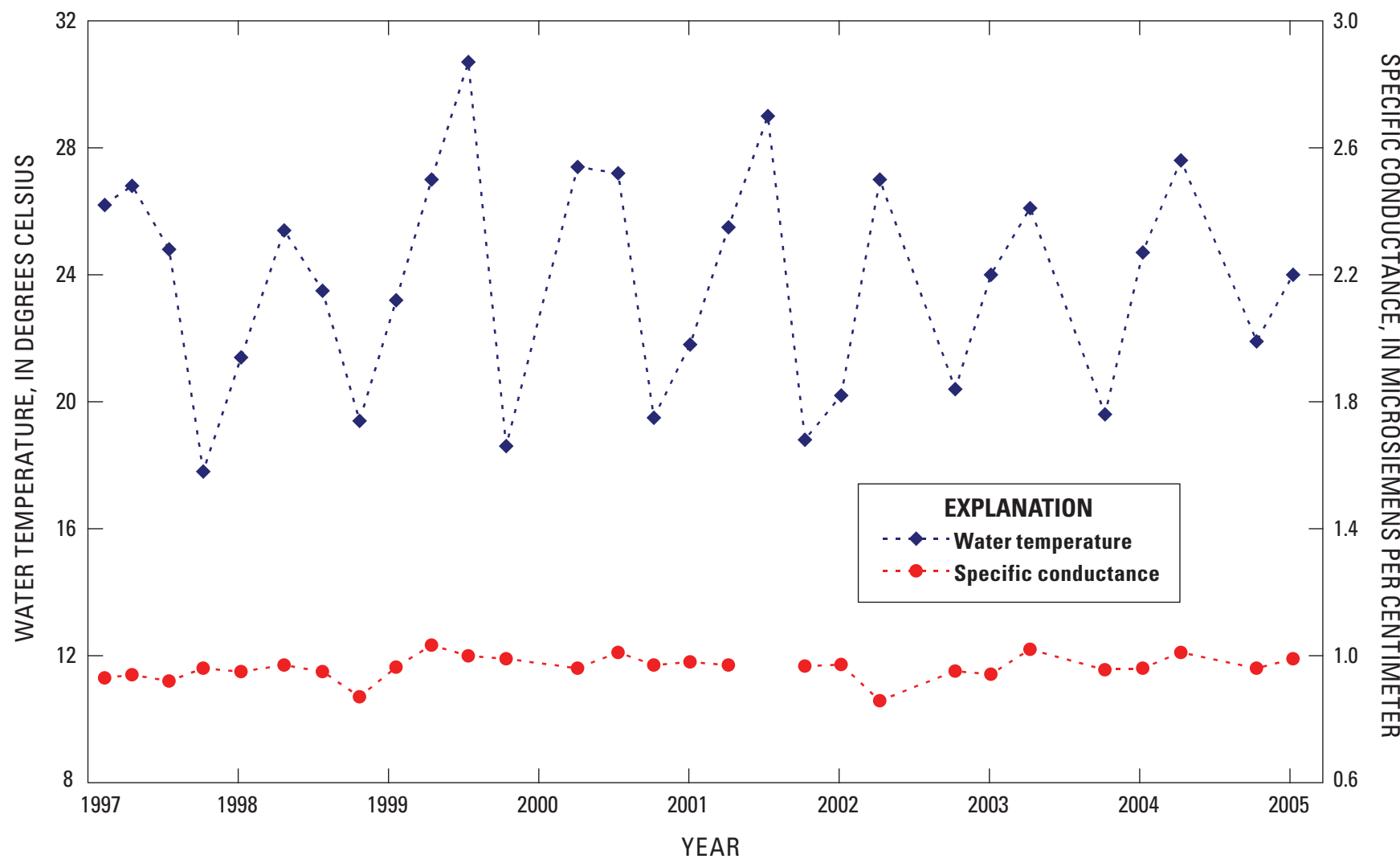

Figure B72. Water-temperature and specific-conductance measurements for site S6 in the Warm Springs area near Moapa, Nevada, 1997-2005. Measurements provided by Converse Consultants. 


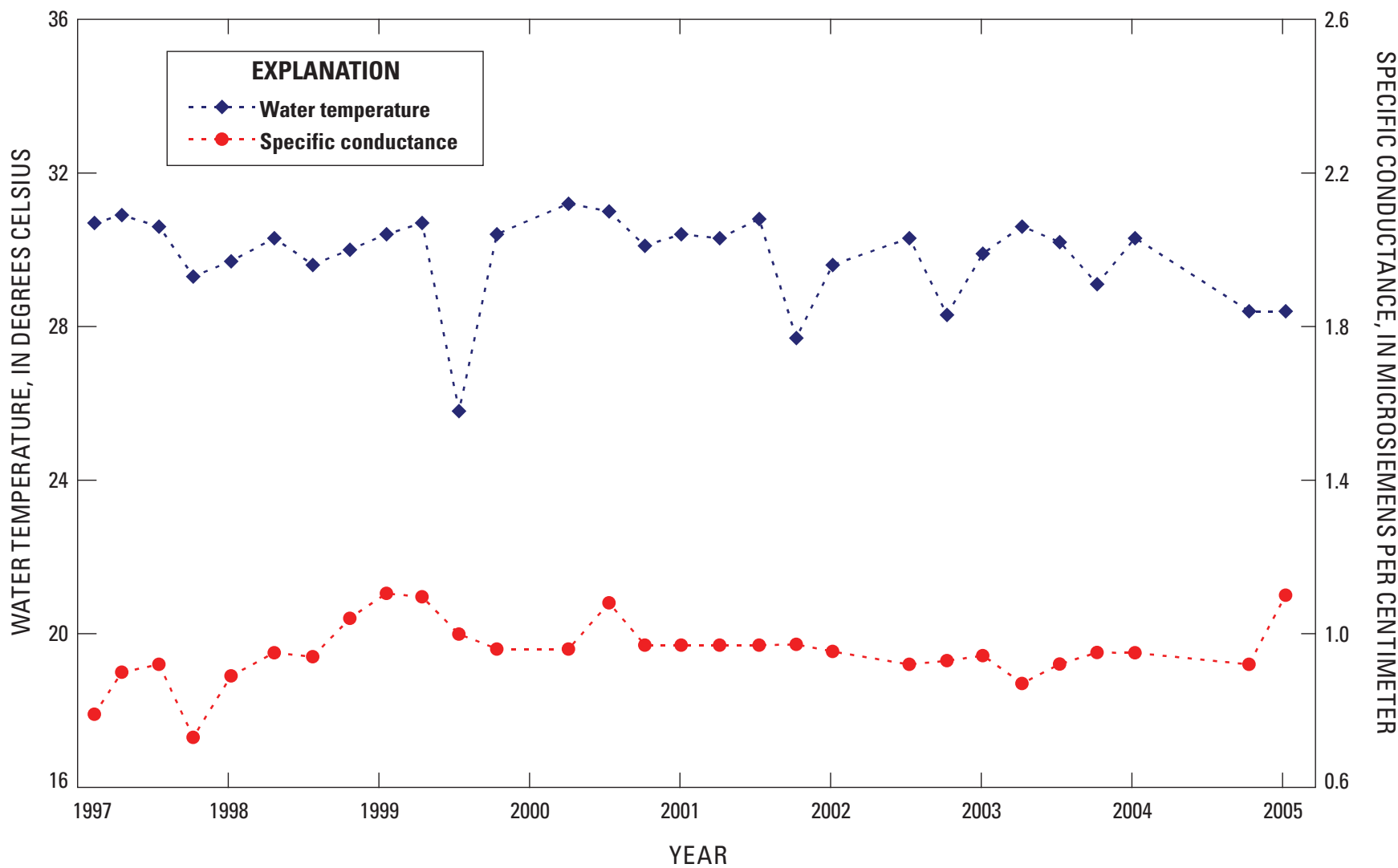

Figure B73. Water-temperature and specific-conductance measurements for site S7a in the Warm Springs area near Moapa, Nevada, 1997-2005. Measurements provided by Converse Consultants. 


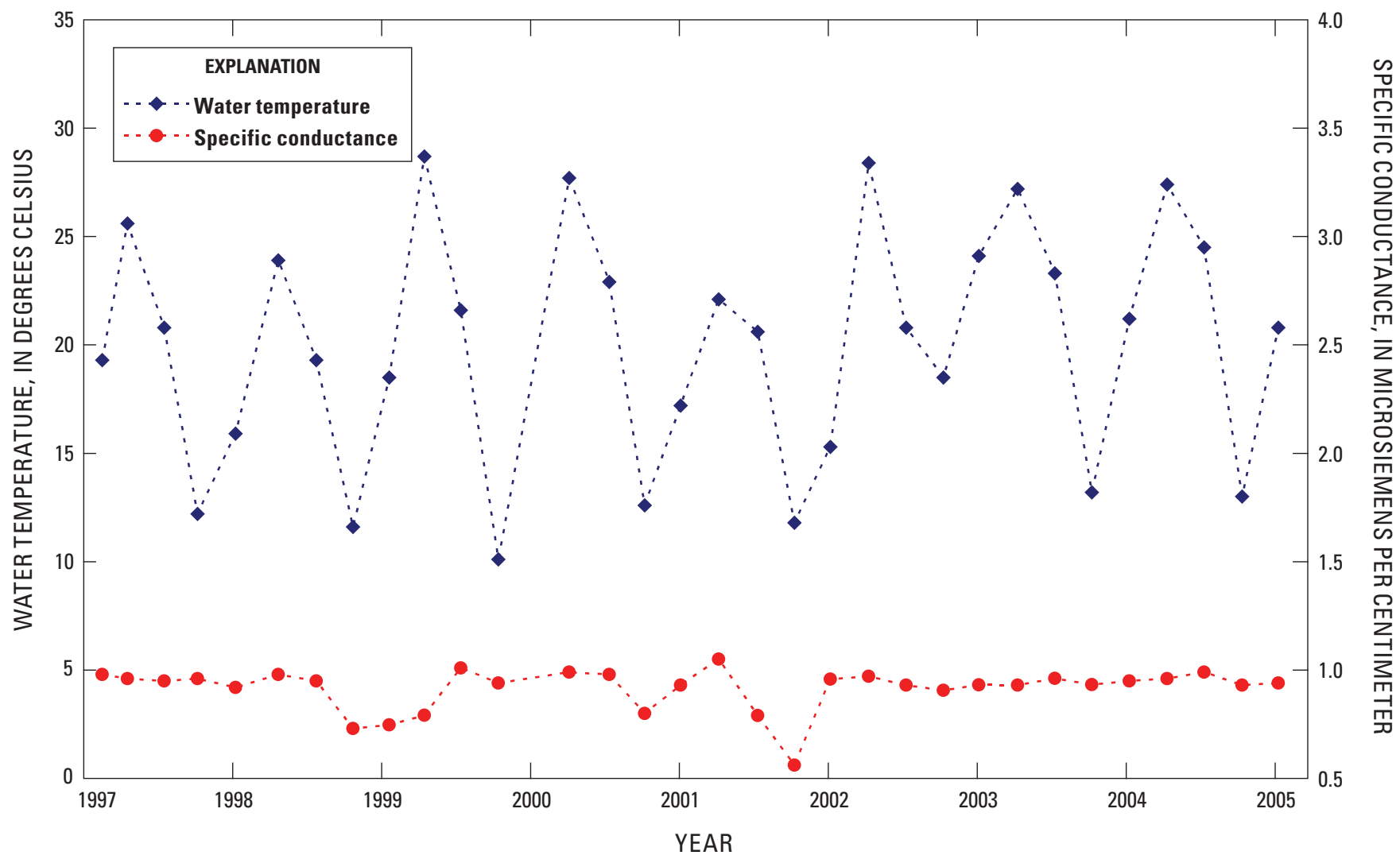

Figure B74. Water-temperature and specific-conductance measurements for site S65 in the Warm Springs area near Moapa, Nevada, 1997-2005. Measurements provided by Converse Consultants. 
Table B53. Water-temperature and specific-conductance measurements by Converse Consultants at site S6 in the Warm Springs area near Moapa, Nevada, 1997-2005.

Table B53 data are available in an Excel data base for download at URL: http://pubs.water.usgs.gov/ofr2006-1311. 
Table B54. Water-temperature and specific-conductance measurements by Converse Consultants at site S7a in the Warm Springs area near Moapa, Nevada, 1997-2005.

Table B54 data are available in an Excel data base for download at URL: http://pubs.water.usgs.gov/ofr2006-1311. 
Table B55. Water-temperature and specific-conductance measurements by Converse Consultants at site S65 in the Warm Springs area near Moapa, Nevada, 1997-2005.

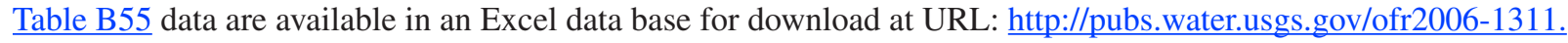


202 Water-Surface Elevations, Discharge, and Water-Quality Data in the Warm Springs Area near Moapa, Nevada

This page left intentionally blank. 

Appendix C. National Geodetic Survey OPUS Solution Reports for Bench Marks Established in the Warm Springs Area near Moapa, Nevada 
204 Water-Surface Elevations, Discharge, and Water-Quality Data in the Warm Springs Area near Moapa, Nevada

This page left intentionally blank. 


\section{WSBM-1 Jones Spring Box}

FILE: PJONES 0370.040 ๑๑०181204 WSBM-1 JONES SPRING BOX

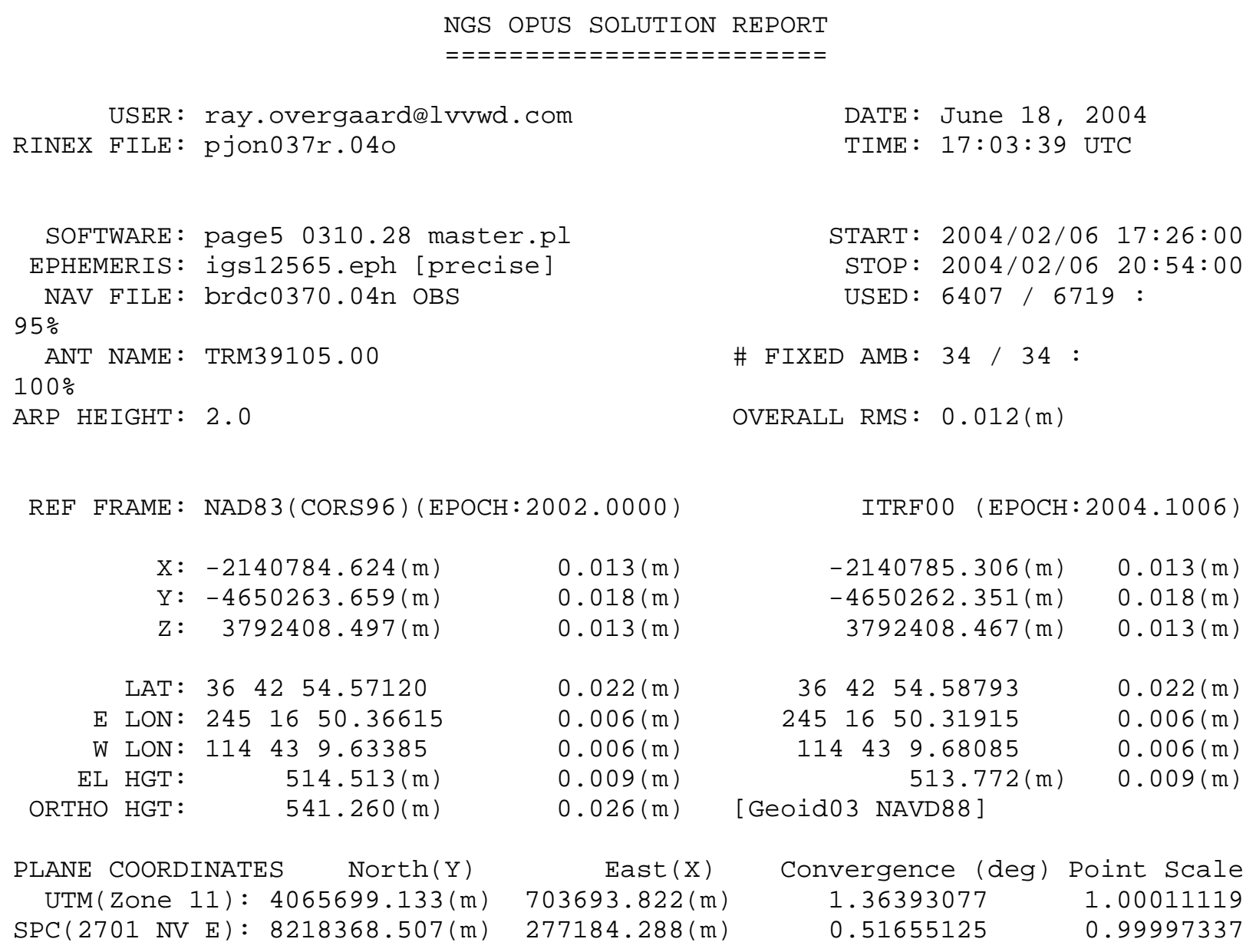

USER: ray. overgaard@lvvwd.com

RINEX FILE: pjon037r.040

SOFTWARE: page5 0310.28 master.pl

EPHEMERIS: igs12565.eph [precise]

NAV FILE: brdc0370.04n OBS $95 \%$

ANT NAME: TRM39105.๑๑

$100 \%$

ARP HEIGHT: 2.0

REF FRAME: NAD83(CORS96)(EPOCH: 2002.0000)

$$
\begin{array}{lr}
X: & -2140784.624(\mathrm{~m}) \\
Y: & -4650263.659(\mathrm{~m}) \\
Z: & 3792408.497(\mathrm{~m})
\end{array}
$$

LAT: $36 \quad 42 \quad 54.57120$

E LON: 2451650.36615

W LON: 114439.63385

EL HGT:

ORTHO HGT:

$514.513(\mathrm{~m})$

$541.260(\mathrm{~m})$

$\odot .013(\mathrm{~m})$

$0.018(\mathrm{~m})$

$0.013(\mathrm{~m})$

$0.022(\mathrm{~m})$

$0.006(\mathrm{~m})$

$0.006(\mathrm{~m})$

$0.009(\mathrm{~m})$

$\odot .026(\mathrm{~m})$

DATE: June 18, 2004

TIME : 17:03:39 UTC

START : $2004 / 02 / 06 \quad 17: 26: 00$ STOP: 2004/02/06 20:54:00 USED : 6407 / 6719 :

\# FIXED AMB: 34 / 34 :

OVERALL RMS: $0.012(\mathrm{~m})$

ITRFO९ (EPOCH: 2004.1006)

$$
\begin{array}{rr}
-2140785.306(\mathrm{~m}) & 0.013(\mathrm{~m}) \\
-4650262.351(\mathrm{~m}) & 0.018(\mathrm{~m}) \\
3792408.467(\mathrm{~m}) & 0.013(\mathrm{~m})
\end{array}
$$

$$
\begin{array}{rrr}
36 & 42 & 54.58793 \\
245 & 16 & 50.31915 \\
114 & 43 & 9.68085 \\
& \multicolumn{3}{c}{513.772(\mathrm{~m})}
\end{array}
$$$$
24516 \quad 50.31915
$$

[Geoid@3 NAVD88]

$$
\begin{aligned}
& \odot .022(\mathrm{~m}) \\
& 0.006(\mathrm{~m}) \\
& 0.006(\mathrm{~m}) \\
& 0.009(\mathrm{~m})
\end{aligned}
$$

\section{$\operatorname{East}(X)$}

Convergence (deg)

1.36393077

0.51655125

Point Scale

1.00011119

$\odot .99997337$

SPC(2701 NV E): 8218368.507(m) 277184.288(m)

US NATIONAL GRID DESIGNATOR: 11SQA0369465699(NAD 83)

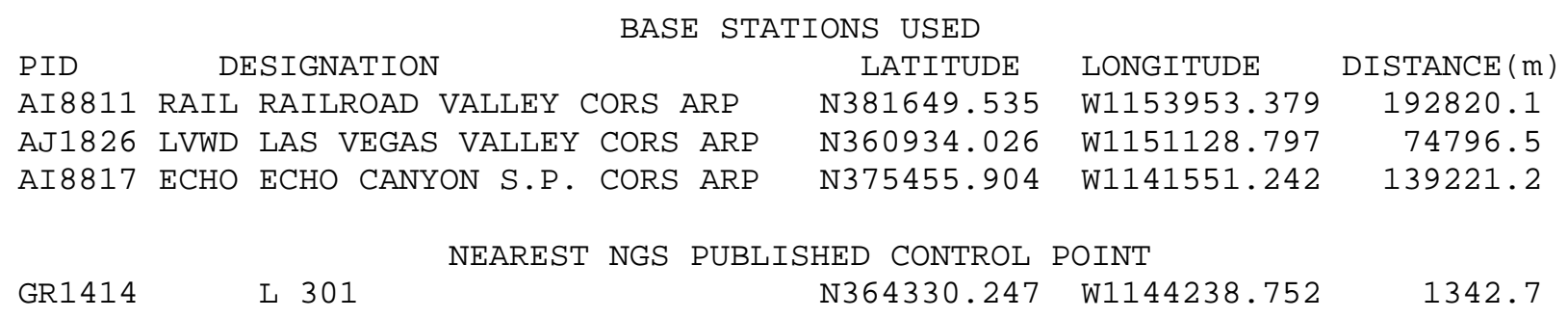

This position was computed without any knowledge by the National Geodetic Survey regarding the equipment or field operating procedures used. 


\section{WSBM-1 Jones Spring Box}

FILE : $63371260.040 \quad 000186248$

WSBM-1 JONES SPRING BOX

NGS OPUS SOLUTION REPORT

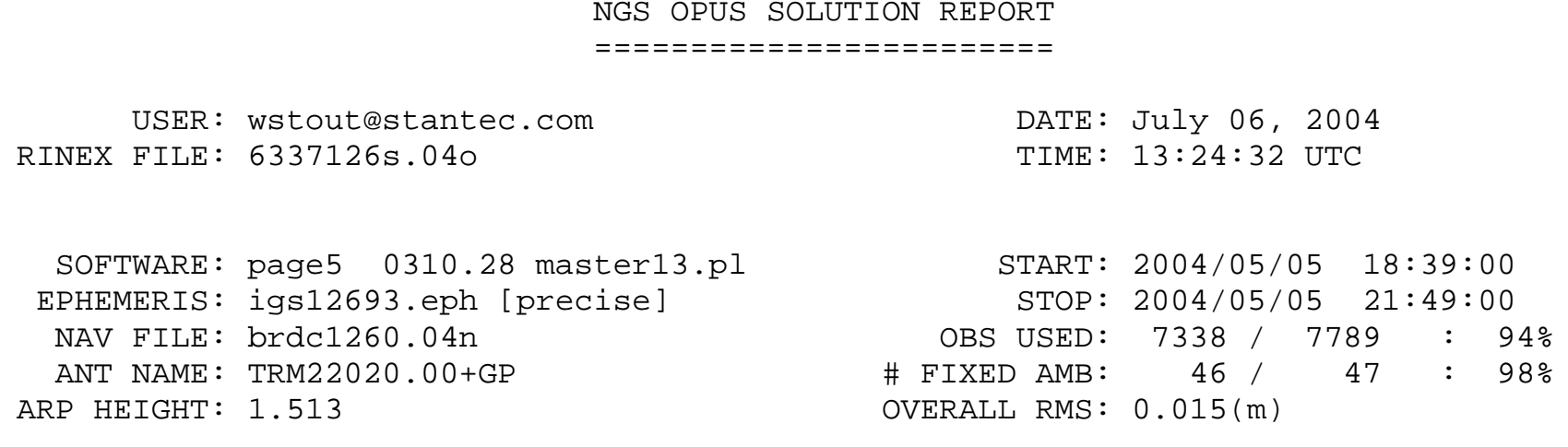

REF FRAME: NAD83(CORS96) (EPOCH : 2002.0000)

ITRFO९ (EPOCH:2004.3438)

$X: \quad-2140784.616(\mathrm{~m})$

$Y: \quad-4650263.643(\mathrm{~m})$

$\odot .0 \odot 8(\mathrm{~m})$

$0.020(\mathrm{~m})$

Z:

$3792408.487(\mathrm{~m})$

$\odot .016(\mathrm{~m})$

$-2140785.303(\mathrm{~m})$
$-4650262.335(\mathrm{~m})$
$3792408.455(\mathrm{~m})$

$0.008(\mathrm{~m})$

$\odot .020(\mathrm{~m})$

LAT: $\quad 3642 \quad 54.57129$

$\odot .025(\mathrm{~m})$

E LON: $24516 \quad 50.36617$

$0.007(\mathrm{~m})$

$0.007(\mathrm{~m})$

W LON:

$11443 \quad 9.63383$

$514.493(\mathrm{~m})$

$0.010(\mathrm{~m})$

ORTHO HGT:

$541.240(\mathrm{~m})$

$\odot .027(\mathrm{~m})$ [Geoid03 NAVD88]

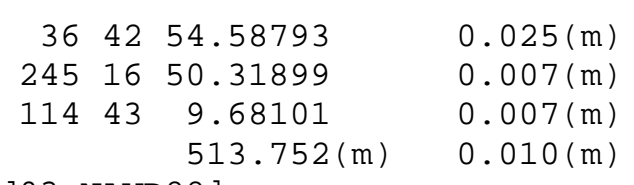

PLANE COORDINATES North $(\mathrm{Y})$

UTM(Zone 11): 4065699.136(m)

$\operatorname{East}(\mathrm{X})$
$703693.822(\mathrm{~m})$

Convergence (deg)

Point Scale

$\operatorname{SPC}(2701 \mathrm{NV} E): \quad 8218368.510(\mathrm{~m})$

$277184.288(\mathrm{~m})$

1.36393077

0.51655125

1.00011119

$\odot .99997337$

US NATIONAL GRID DESIGNATOR: 11SQA0369465699(NAD 83)

\begin{tabular}{|c|c|c|c|c|c|c|}
\hline \multicolumn{7}{|c|}{ BASE STATIONS USED } \\
\hline PID & & ESIGNATION & & LATITUDE & LONGITUDE & $\operatorname{DISTANCE}(m)$ \\
\hline AJ1826 & LVWD & LAS VEGAS VALLEY & CORS ARP & N360934 . 026 & W1151128.797 & 74796.5 \\
\hline AI8817 & $\mathrm{ECHO}$ & ECHO CANYON S.P. & CORS ARP & N375455.904 & W1141551. 242 & 139221.2 \\
\hline AM7015 & KING & KINGMAN CORS ARP & & N351150. 480 & W1140229. 275 & 179188.7 \\
\hline & & NEAREST NGS & PUBLISHED & CONTROL POINT & & \\
\hline GR1414 & & L 301 & & $N 364330.247$ & W1144238.752 & 1342.7 \\
\hline
\end{tabular}




\section{WSBM-2 Pipeline Jones Flume}

FILE：PLJF2@22.๑40 $\odot \odot \odot 19769 \odot$

WSBM-2 PIPELINE JONES FLUME

NGS OPUS SOLUTION REPORT

=ニニニニニニ=ニニニニ=ニ=ニニ=ニニニ=ニ=

USER: harper@usgs.gov

RINEX FILE: pljf202q.04o

SOFTWARE: page5 0407.16 master.pl

EPHEMERIS: igs12802.eph [precise]

NAV FILE: brdc2020.04n 91\%

ANT NAME: ASH701975.01B

85\%

ARP HEIGHT: 1.618994284

REF FRAME: NAD83(CORS96)(EPOCH: 2002.0000)

$X: \quad-2140422.324(\mathrm{~m})$

$Y: \quad-4650504.929(\mathrm{~m})$

$\mathrm{Z:} \quad 3792297.200(\mathrm{~m})$

$0.032(\mathrm{~m})$

$0.093(\mathrm{~m})$

$\odot .061(\mathrm{~m})$

LAT: $\quad 36 \quad 4250.36476$

E LON: $24517 \quad 7.69085$

W LON: 1144252.30915

EL HGT:

ORTHO HGT:

$502.227(\mathrm{~m})$

$528.987(\mathrm{~m})$ $0.014(\mathrm{~m})$

$0.014(\mathrm{~m})$

$0.014(\mathrm{~m})$

$0.114(\mathrm{~m})$

$\odot .117(\mathrm{~m})$
DATE: August 06,2004

TIME : 23:23:16 UTC

$\begin{array}{lcccc}\text { PLANE COORDINATES } & \text { North }(\mathrm{Y}) & \text { East }(\mathrm{X}) & \text { Convergence (deg) } & \text { Point Scale } \\ \text { UTM(Zone 11): } & 4065579.735(\mathrm{~m}) & 704126.795(\mathrm{~m}) & 1.36677342 & 1.00011337 \\ \text { SPC }(2701 \mathrm{NV} \text { E }): & 8218242.737(\mathrm{~m}) & 277615.388(\mathrm{~m}) & 0.51941452 & 0.99997419\end{array}$

US NATIONAL GRID DESIGNATOR: 11SQA0412765580(NAD 83)

\begin{tabular}{|c|c|c|c|c|c|}
\hline \multicolumn{6}{|c|}{ BASE STATIONS USED } \\
\hline PID & & ESIGNATION & LATITUDE & \multicolumn{2}{|c|}{ LONGITUDE DISTANCE $(\mathrm{m})$} \\
\hline AJ1826 & LVWD & LAS VEGAS VALLEY CORS ARP & N360934. $\odot 26$ & W1151128.797 & 74935.1 \\
\hline DG4673 & NVCS & CARLTON SQUARE CORS ARP & N361311. 196 & W1151019.335 & 68482.8 \\
\hline DG4263 & NVLK & A M SMITH WTF CORS ARP & N360410.758 & W1144847.501 & 72049.9 \\
\hline \multicolumn{6}{|c|}{ NEAREST NGS PUBLISHED CONTROL POINT } \\
\hline GR1414 & & L 301 & N364330. 247 & W1144238.752 & 1278.2 \\
\hline
\end{tabular}

This position was computed without any knowledge by the National Geodetic Survey regarding the equipment or field operating procedures used. 


\section{WSBM-3 Baldwin Spring}

FILE: BALDW0370.040 000179255 WSBM-3 BALDWIN SPRING

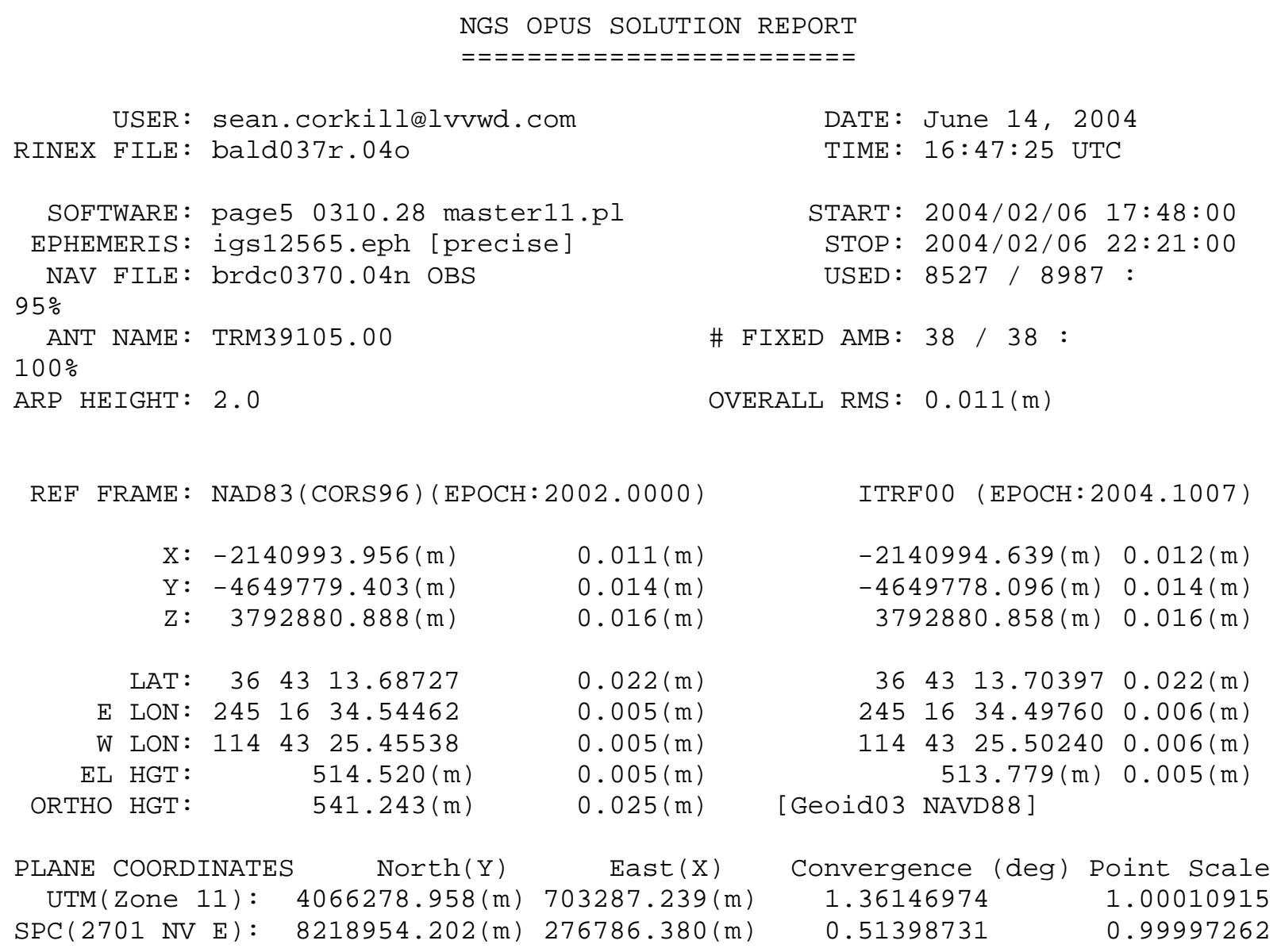

USER: sean.corkill@lvvwd.com

RINEX FILE: bald037r.040

SOFTWARE: page5 0310.28 master11.pl

EPHEMERIS: igs12565.eph [precise]

NAV FILE: brdc0370.04n OBS 95\%

ANT NAME: TRM39105.๑०

$100 \%$

ARP HEIGHT: 2.0

DATE: June 14, 2004

TIME : $16: 47: 25$ UTC

START: $2004 / 02 / 06 \quad 17: 48: 0 \odot$

STOP: $2004 / 02 / 06$ 22:21:00

USED : 8527 / 8987 :

\# FIXED AMB: 38 / 38 :

OVERALL RMS: $\odot .011(\mathrm{~m})$

REF FRAME: NAD83(CORS96)(EPOCH: 2002.0000)

$$
\begin{array}{lr}
X: & -2140993.956(\mathrm{~m}) \\
Y: & -4649779.403(\mathrm{~m}) \\
\mathrm{Z}: & 3792880.888(\mathrm{~m})
\end{array}
$$

LAT: $\quad \begin{array}{lll}36 & 43 & 13.68727\end{array}$

E LON: $24516 \quad 34.54462$

W LON: 1144325.45538

EL HGT:

ORTHO HGT:

$541.243(\mathrm{~m})$

$$
\begin{aligned}
& 0.011(\mathrm{~m}) \\
& 0.014(\mathrm{~m}) \\
& 0.016(\mathrm{~m})
\end{aligned}
$$

$0.022(\mathrm{~m})$

$0.005(\mathrm{~m})$

$0.005(\mathrm{~m})$

$0.005(\mathrm{~m})$

$\odot .025(\mathrm{~m})$

ITRFO९ (EPOCH:2004.1007)

$-2140994.639(\mathrm{~m}) \quad 0.012(\mathrm{~m})$

$-4649778.096(\mathrm{~m}) \quad 0.014(\mathrm{~m})$ $3792880.858(\mathrm{~m}) \quad 0.016(\mathrm{~m})$

\begin{tabular}{|c|c|c|c|c|}
\hline -AIVE COUR & $\operatorname{th}(Y)$ & East $(X)$ & Convergence (deg) & Point \\
\hline UTM(Zone 11): & $4066278.958(\mathrm{~m})$ & $703287.239(\mathrm{~m})$ & 1.36146974 & \\
\hline $\operatorname{SPC}(2701$ NV E $):$ & $8218954.202(\mathrm{~m})$ & $276786.380(\mathrm{~m})$ & $\odot .51398731$ & .9999 \\
\hline
\end{tabular}

$\begin{array}{llll}36 & 43 & 13.70397 \quad 0.022(\mathrm{~m})\end{array}$

$2451634.49760 \quad 0.006(\mathrm{~m})$

$1144325.502400 .006(\mathrm{~m})$ $513.779(\mathrm{~m}) \quad 0.005(\mathrm{~m})$

[Geoid03 NAVD88]

US NATIONAL GRID DESIGNATOR: 11SQA0328766279(NAD 83)

\begin{tabular}{lccccr}
\multicolumn{5}{c}{ BASE STATIONS USED } \\
PID & DESIGNATION & LATITUDE & LONGITUDE & DISTANCE $(\mathrm{m})$ \\
AI8811 & RAIL RAILROAD VALLEY CORS ARP & N381649.535 & W1153953.379 & 192119.4 \\
AJ1826 & LVWD LAS VEGAS VALLEY CORS ARP & N360934.026 & W1151128.797 & 75061.4 \\
AI8817 & ECHO ECHO CANYON S.P. CORS ARP & N375455.904 & W1141551.242 & 138770.8 \\
\multicolumn{5}{c}{ NEAREST NGS PUBLISHED CONTROL POINT } \\
GR0790 & M 301 & N364354. & W1144332. &
\end{tabular}

This position was computed without any knowledge by the National Geodetic Survey regarding the equipment or field operating procedures used. 


\section{WSBM-3 Baldwin Spring}

FILE: 98511260.040000186245

WSBM-3 BALDWIN SPRING

NGS OPUS SOLUTION REPORT

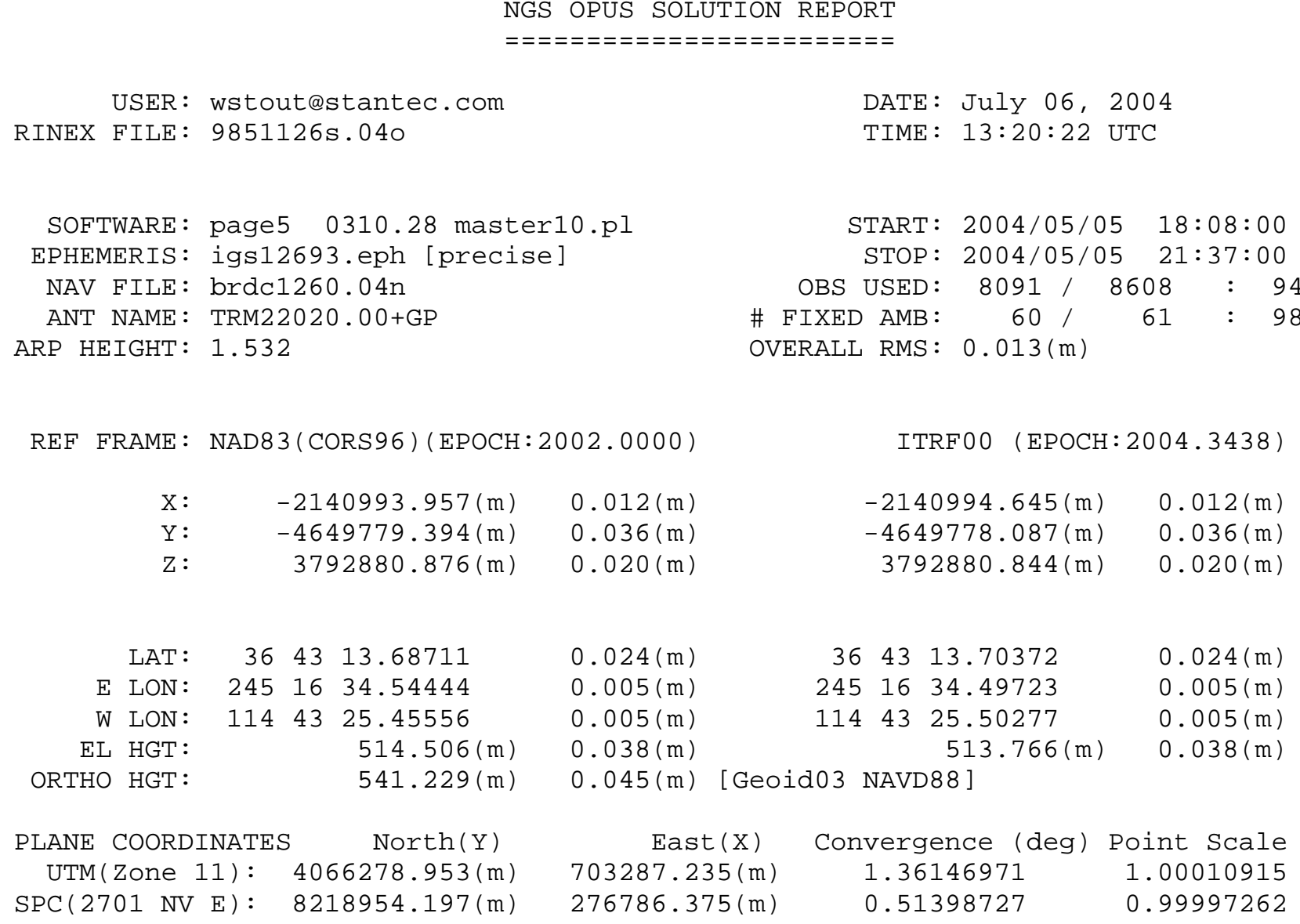

US NATIONAL GRID DESIGNATOR: 11SQA0328766279(NAD 83)

\begin{tabular}{|c|c|c|c|c|c|c|}
\hline \multicolumn{7}{|c|}{ BASE STATIONS USED } \\
\hline PID & & SIGNATION & & LATITUDE & LONGITUDE & $\operatorname{ISTANCE}(\mathrm{m})$ \\
\hline AJ1826 & LVWD & LAS VEGAS VALLEY & CORS ARP & N360934 . $\odot 26$ & W1151128.797 & 75061.4 \\
\hline AI8817 & ECHO & ECHO CANYON S.P. & CORS ARP & N375455.904 & W1141551. 242 & 138770.8 \\
\hline AM7015 & KING & KINGMAN CORS ARP & & N351150. 480 & W1140229. 275 & 179877.2 \\
\hline RO790 & & M $3011^{\text {NEAREST NGS }}$ & Sth & $\begin{array}{l}\text { TROL POINT } \\
\text { N364354. }\end{array}$ & W1144332. & 1257.1 \\
\hline
\end{tabular}

This position was computed without any knowledge by the National Geodetic Survey regarding the equipment or field operating procedures used. 


\section{WSBM-4 Warm Springs Road near Iverson Flume}

FILE : $63371280.040 \quad 000186246$

WSBM-4 WARM SPRINGS ROAD NEAR IVERSON FLUME

NGS OPUS SOLUTION REPORT

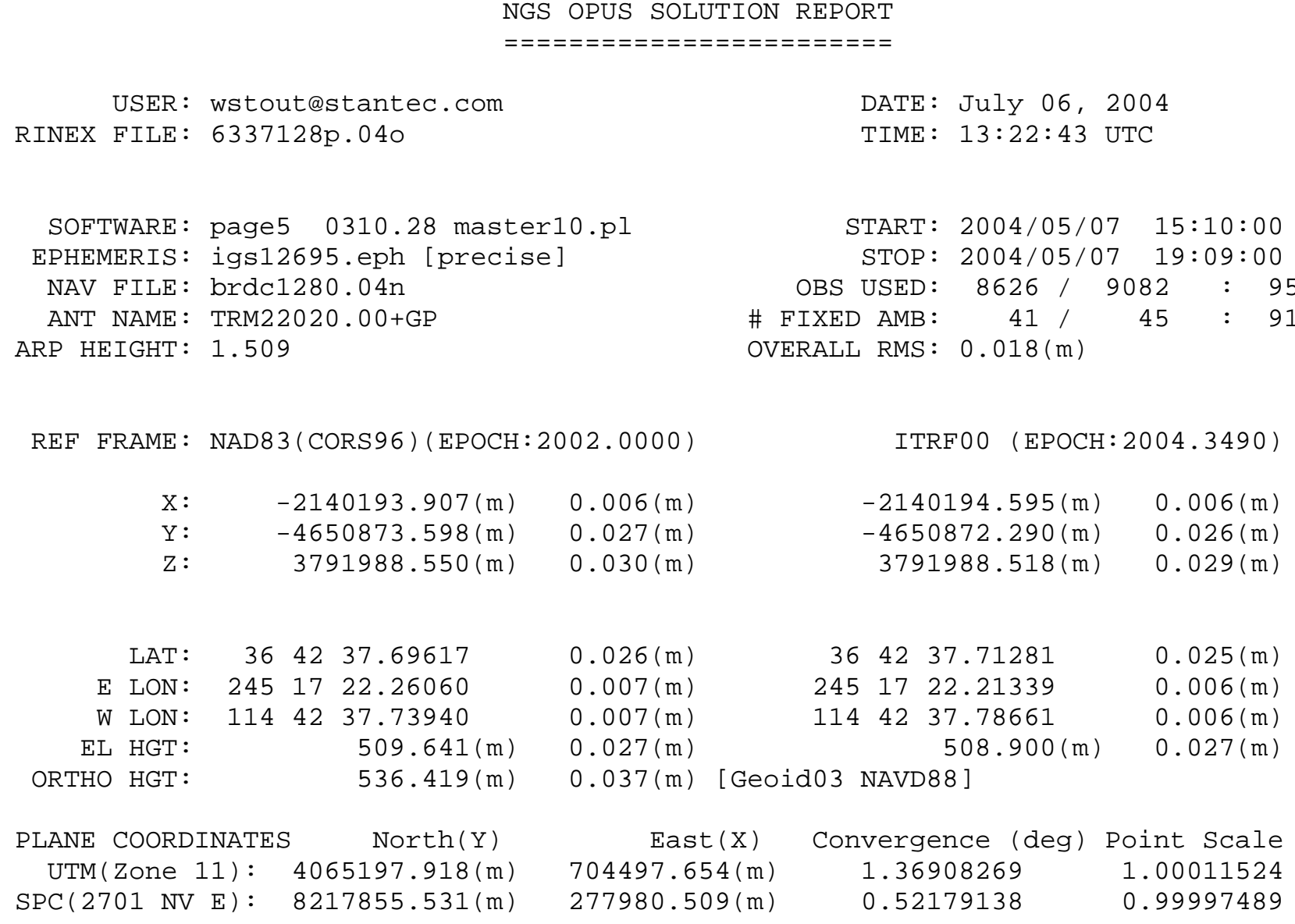

US NATIONAL GRID DESIGNATOR: 11SQAO449865198(NAD 83)

\begin{tabular}{lcccccc}
\multicolumn{2}{c}{ BASE STATIONS USED } \\
PID & DESIGNATION & \multicolumn{3}{c}{ LATITUDE } & LONGITUDE & DISTANCE $(\mathrm{m})$ \\
AJ1826 & LVWD LAS VEGAS VALLEY & CORS ARP & N360934.026 & W1151128.797 & 74823.8 \\
AI8817 & ECHO ECHO CANYON S.P. CORS ARP & N375455.904 & W1141551.242 & 139494.8 \\
AM7015 & KING KINGMAN CORS ARP & & N351150.480 W1140229.275 & 178428.4
\end{tabular}

GR1414

NEAREST NGS PUBLISHED CONTROL POINT

This position was computed without any knowledge by the National Geodetic Survey regarding the equipment or field operating procedures used. 


\section{WSBM-5 Iverson Flume}

FILE: IVRF1340.020 000181214 WSBM-5 Iverson Flume

\section{NGS OPUS SOLUTION REPORT}

USER: timothy.wolf \@lvvwd.com

RINEX FILE: ivrf1340.020

Iverson Flume

SOFTWARE: page5 0203.19

EPHEMERIS: igs11662.eph [precise]

NAV FILE: brdc1340.02n

ANT NAME: TRM33429.00-GP

ARP HEIGHT: 2.064

REF FRAME: NAD83(CORS96)(EPOCH:2002.0000)

$X: \quad-2140100.670(\mathrm{~m})$

$Y: \quad-4650849.449(\mathrm{~m})$

Z: $\quad 3792063.111(\mathrm{~m})$

LAT: $\quad 3642 \quad 40.81624$

E LON: 2451725.26635

W LON: 1144234.73365

EL HGT:

ORTHO HGT:

$505.380(\mathrm{~m})$

$532.232(\mathrm{~m})$

$\odot .040(\mathrm{~m})$

$0.039(\mathrm{~m})$

$\odot .035(\mathrm{~m})$

$0.043(\mathrm{~m})$

$0.045(\mathrm{~m})$

$0.045(\mathrm{~m})$

$0.020(\mathrm{~m})$

$0.032(\mathrm{~m})$

Zone 11

NORTHING :

EASTING :

SPC: Zone 2701(NV)

NORTHING : $\quad 8217952.382(\mathrm{~m})$

EASTING: $\quad 278054.227(\mathrm{~m})$
DATE: June 20, 2002

TIME : $0 \odot: 45: 56$ UTC

\author{
START: $2002 / 05 / 14 \quad 18: 19: 00$ \\ STOP: $2002 / 05 / 14$ 21:32:00 \\ OBS USED: $6548 / 8503: 77 \%$ \\ \# FIXED AMB: $56 / 88: 64 \%$ \\ OVERALL RMS: $0.031(\mathrm{~m})$
}

ITRFO९ (EPOCH:2002.3667)

$\begin{array}{rr}-2140101.316(\mathrm{~m}) & 0.039(\mathrm{~m}) \\ -4650848.146(\mathrm{~m}) & 0.039(\mathrm{~m}) \\ 3792063.095(\mathrm{~m}) & 0.035(\mathrm{~m})\end{array}$

$\begin{array}{llll}36 & 42 & 40.83353 & 0.044(\mathrm{~m})\end{array}$

$24517 \quad 25.22076 \quad 0.056(\mathrm{~m})$

$1144234.77924 \quad 0.056(\mathrm{~m})$

[Geoid99 NAVD88]

BASE STATIONS USED

$\begin{array}{lcccc}\text { PID } & \text { DESIGNATION } & \text { LATITUDE LONGITUDE } & \text { DISTANCE(m) } \\ \text { AJ1826 } & \text { lVwd LAS VEGAS VALLEY CORS ARP } & \text { N360934 W1151128 } & 74945 \\ \text { AI8817 } & \text { echo ECHO CANYON S.P. CORS ARP } & \text { N375455 W1141551 } & 139381 \\ \text { AM7015 king KINGMAN CORS ARP } & \text { N351150 W1140229 } & 178493 \\ & \text { NEAREST NGS PUBLISHED CONTROL POINT } & \\ \text { GR1414 } & \text { L } 301 & \text { N364330 W1144235 } & 1521\end{array}$

This position was computed without any knowledge by the National Geodetic Survey regarding the equipment or field operating procedures used. 


\section{WSBM-6 Pederson Spring}

FILE : $98511270.040 \quad 000186254$

\section{WSBM- 6 PEDERSON SPRING}

NGS OPUS SOLUTION REPORT

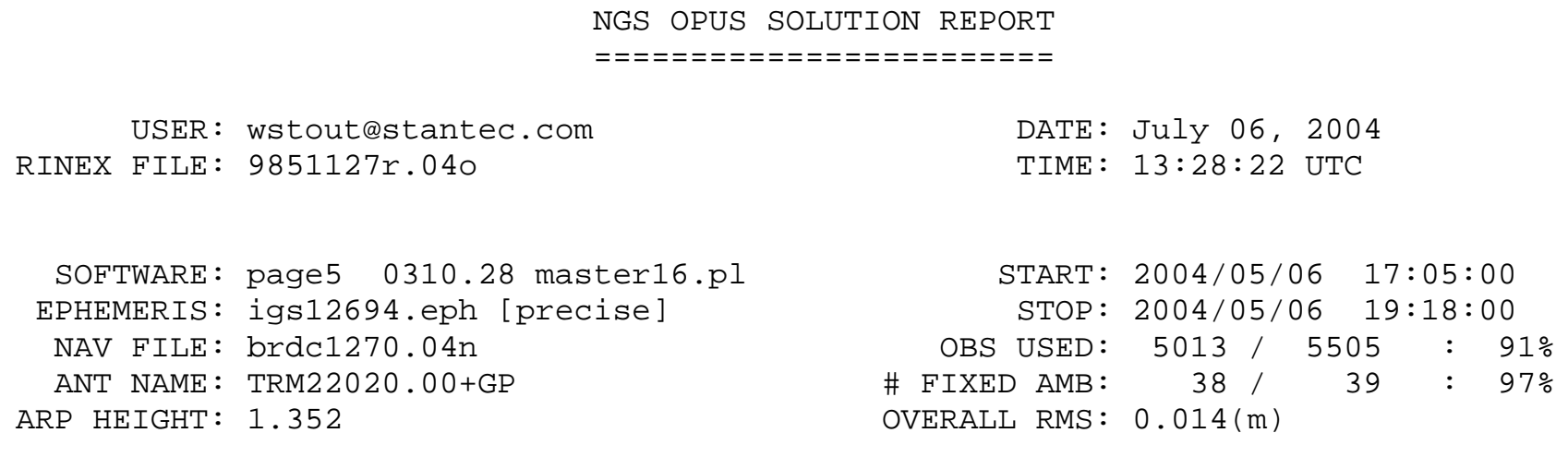

REF FRAME: NAD83(CORS96)(EPOCH : 2002.0000)

ITRFO९ (EPOCH: 2004.3463)
$X: \quad-2140635.851(\mathrm{~m})$
$\mathrm{Y}: \quad-4650789.717(\mathrm{~m})$
Z: $\quad 3791874.611(\mathrm{~m})$
$0.021(\mathrm{~m})$
$0.050(\mathrm{~m})$
$0.033(\mathrm{~m})$

$-2140636.539(\mathrm{~m})$
$-4650788.409(\mathrm{~m})$
$3791874.579(\mathrm{~m})$

$0.021(\mathrm{~m})$

$\odot .050(\mathrm{~m})$

LAT: $\quad 36 \quad 42 \quad 32.62813$

$\odot .023(\mathrm{~m})$

E LON: $24517 \quad 4.67332$

$0.006(\mathrm{~m})$

W LON :

$0.006(\mathrm{~m})$

EL HGT:

$114 \quad 42 \quad 55.32668$

$0.057(\mathrm{~m})$

ORTHO HGT:

$528.567(\mathrm{~m})$

$0.062(\mathrm{~m})$
$\begin{array}{lll}36 & 42 & 32.64476\end{array}$
$\begin{array}{lll}245 & 17 & 4.62611\end{array}$
$\begin{array}{lll}114 & 42 & 55.37389\end{array}$
$527.826(\mathrm{~m})$

$\odot .033(\mathrm{~m})$

PLANE COORDINATES North $(\mathrm{Y})$

UTM(Zone 11): 4065031.300(m)

$\operatorname{East}(\mathrm{X})$

$(\mathrm{X})$
$7(\mathrm{~m})$

$277545.456(\mathrm{~m})$

Convergence (deg)

1.36611433

0.51885352

$\odot .022(\mathrm{~m})$

$0.006(\mathrm{~m})$

$0.006(\mathrm{~m})$

$0.057(\mathrm{~m})$

SPC (2701 NV E): $\quad 8217695.352(\mathrm{~m})$

US NATIONAL GRID DESIGNATOR: 11SQA0406565031(NAD 83)

US NATIONAL GRID DESIGNATOR: 11SQA@406565031(NAD 83)

\begin{tabular}{|c|c|c|c|c|c|c|}
\hline \multicolumn{7}{|c|}{ BASE STATIONS USED } \\
\hline PID & & ESIGNATION & & LATITUDE & LONGITUDE & $\operatorname{ISTANCE}(\mathrm{m})$ \\
\hline AJ1826 & LVWD & LAS VEGAS VALLEY & CORS ARP & N360934. . 026 & W1151128.797 & 74444.4 \\
\hline AI8817 & $\mathrm{ECHO}$ & ECHO CANYON S.P. & CORS ARP & N375455.904 & W1141551.242 & 139768.1 \\
\hline AM7015 & KING & KINGMAN CORS ARP & & N351150 . 480 & W1140229.275 & 178431.5 \\
\hline GR1414 & & 301 NEAREST NGS & PUBLISHED & $\begin{array}{l}\text { CONTROL POINT } \\
\text { N364330,247 }\end{array}$ & $711111228 \quad 752$ & $1828 \quad 5$ \\
\hline
\end{tabular}




\section{WSBM-7 Warm Spring West}

FILE: 63371270.040000186256

WSBM-7 WARM SPRINGS WEST

NGS OPUS SOLUTION REPORT

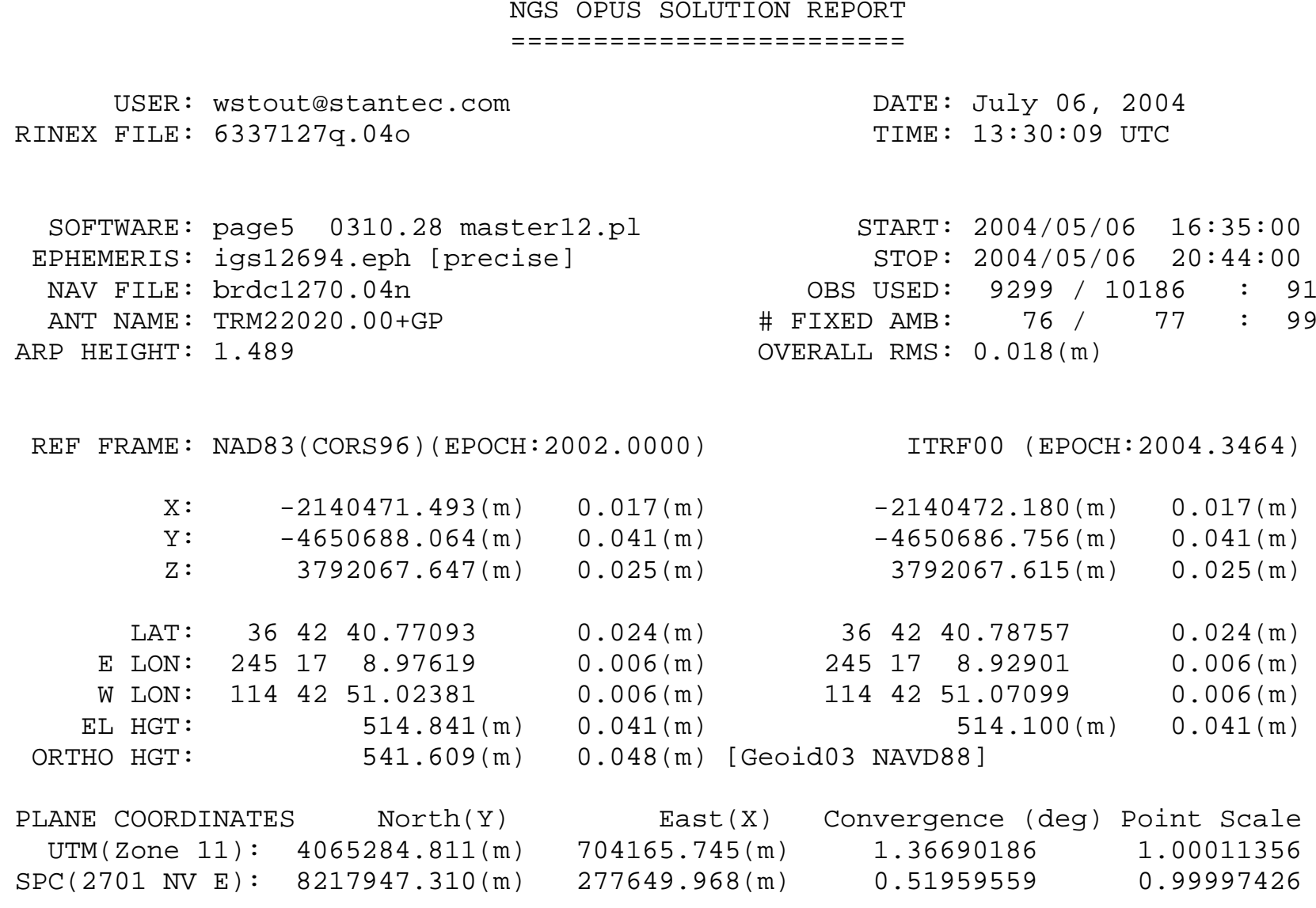

US NATIONAL GRID DESIGNATOR: 11SQAO416665285(NAD 83)

\begin{tabular}{|c|c|c|c|c|c|c|}
\hline \multicolumn{7}{|c|}{ BASE STATIONS USED } \\
\hline PID & & ESIGNATION & & LATITUDE & LONGITUDE & $\operatorname{ISTANCE}(m)$ \\
\hline AJ1826 & LVWD & LAS VEGAS VALLEY & CORS ARP & N360934 . 026 & W1151128.797 & 74711.2 \\
\hline AI8817 & $\mathrm{ECHO}$ & ECHO CANYON S.P. & CORS ARP & N375455. 904 & W1141551.242 & 139497.0 \\
\hline AM7015 & KING & KINGMAN CORS ARP & & N351150. 480 & W1140229.275 & 178630.4 \\
\hline GR1414 & & L $301{ }^{\text {NEAREST NGS }}$ & PUBLISHED & $\begin{array}{l}\text { ROL POINT } \\
\text { N364330.247 }\end{array}$ & W1144238.752 & 1559.9 \\
\hline
\end{tabular}

This position was computed without any knowledge by the National Geodetic Survey regarding the equipment or field operating procedures used. 


\title{
WSBM-8 Plummer Springs
}

FILE: lowerspg.๑40 000186250

\section{WSBM-8 PLUMMER SPRINGS}

NGS OPUS SOLUTION REPORT

\author{
=ニ=ニ=ニ=ニ=ニ=ニ=ニ=ニ=ニ=ニ=ニ== \\ USER: wstout@stantec.com \\ RINEX FILE: lowe127r.040 \\ SOFTWARE: page5 0310.28 master $11 . p 1$ \\ EPHEMERIS: igs12694.eph [precise] \\ NAV FILE: brdc1270.04n \\ ANT NAME: TRM22020.00+GP \\ ARP HEIGHT: 1.497 \\ DATE: July 06,2004 \\ TIME: 13:26:19 UTC \\ START: $2004 / 05 / 06 \quad 17: 44: 00$ \\ STOP: $2004 / 05 / 06 \quad 21: 10: 00$ \\ OBS USED: $6437 / 8167: 79 \%$ \\ \# FIXED AMB: $59 / 62: 95 \%$ \\ OVERALL RMS: $0.018(\mathrm{~m})$
}

REF FRAME: NAD83(CORS96) (EPOCH : 2002.0000)

$$
\begin{array}{lrl}
X: & -2140333.281(\mathrm{~m}) & 0.025(\mathrm{~m}) \\
\mathrm{Y}: & -4650782.745(\mathrm{~m}) & 0.059(\mathrm{~m}) \\
\mathrm{Z}: & 3792016.409(\mathrm{~m}) & 0.035(\mathrm{~m})
\end{array}
$$

LAT: $\quad 3642 \quad 38.89120$

E LON: 2451715.62940

W LON: 1144244.37060

EL HGT:

ORTHO HGT:

$$
506.840(\mathrm{~m})
$$$$
533.613(\mathrm{~m})
$$

$\odot .025(\mathrm{~m})$

$0.008(\mathrm{~m})$

$0.008(\mathrm{~m})$

$0.064(\mathrm{~m})$

$0.068(\mathrm{~m})$

$\begin{array}{ccccc}\text { PLANE COORDINATES } & \text { North }(\mathrm{Y}) & \text { East }(\mathrm{X}) & \text { Convergence (deg) } & \text { Point Scale } \\ \text { UTM }(\text { Zone 11): } & 4065230.818(\mathrm{~m}) & 704332.224(\mathrm{~m}) & 1.36799107 & 1.00011440 \\ \text { SPC }(2701 \text { NV E }): & 8217890.869(\mathrm{~m}) & 277815.607(\mathrm{~m}) & 0.52069416 & 0.99997458\end{array}$

US NATIONAL GRID DESIGNATOR: 11SQA@433265231(NAD 83)

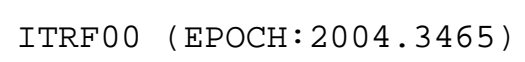

$$
\begin{array}{rr}
-2140333.969(\mathrm{~m}) & 0.025(\mathrm{~m}) \\
-4650781.438(\mathrm{~m}) & 0.059(\mathrm{~m}) \\
3792016.377(\mathrm{~m}) & 0.035(\mathrm{~m})
\end{array}
$$

\begin{tabular}{|c|c|c|c|c|c|c|}
\hline \multicolumn{7}{|c|}{ BASE STATIONS USED } \\
\hline PID & & ESIGNATION & & LATITUDE & LONGITUDE & $\operatorname{DISTANCE}(m)$ \\
\hline AJ1826 & LVWD & LAS VEGAS VALLEY & CORS ARP & N360934.026 & W1151128.797 & 74758.8 \\
\hline AI8817 & $\mathrm{ECHO}$ & ECHO CANYON S.P. & CORS ARP & N375455.904 & W1141551. 242 & 139505.8 \\
\hline AM7015 & KING & KINGMAN CORS ARP & & N351150 . 480 & W1140229.275 & 178519.3 \\
\hline & & NEAREST NGS & PUBLISHED & CONTROL POINT & & \\
\hline GR1414 & & L 301 & & N364330. 247 & W1144238.752 & 1594.2 \\
\hline
\end{tabular}

$\begin{array}{rrr}36 & 42 & 38.90782\end{array}$

$\begin{array}{lll}245 & 17 & 15.58221\end{array}$

$\begin{array}{lll}114 & 42 \quad 44.41779\end{array}$

$\odot .025(\mathrm{~m})$

$\odot .008(\mathrm{~m})$

$\odot .008(\mathrm{~m})$ $506.099(\mathrm{~m})$

$0.064(\mathrm{~m})$ 


\section{WSBM-9 Moapa Gage}

FILE: moapa. 040000186252

WSBM-9 MOAPA GAGE

NGS OPUS SOLUTION REPORT

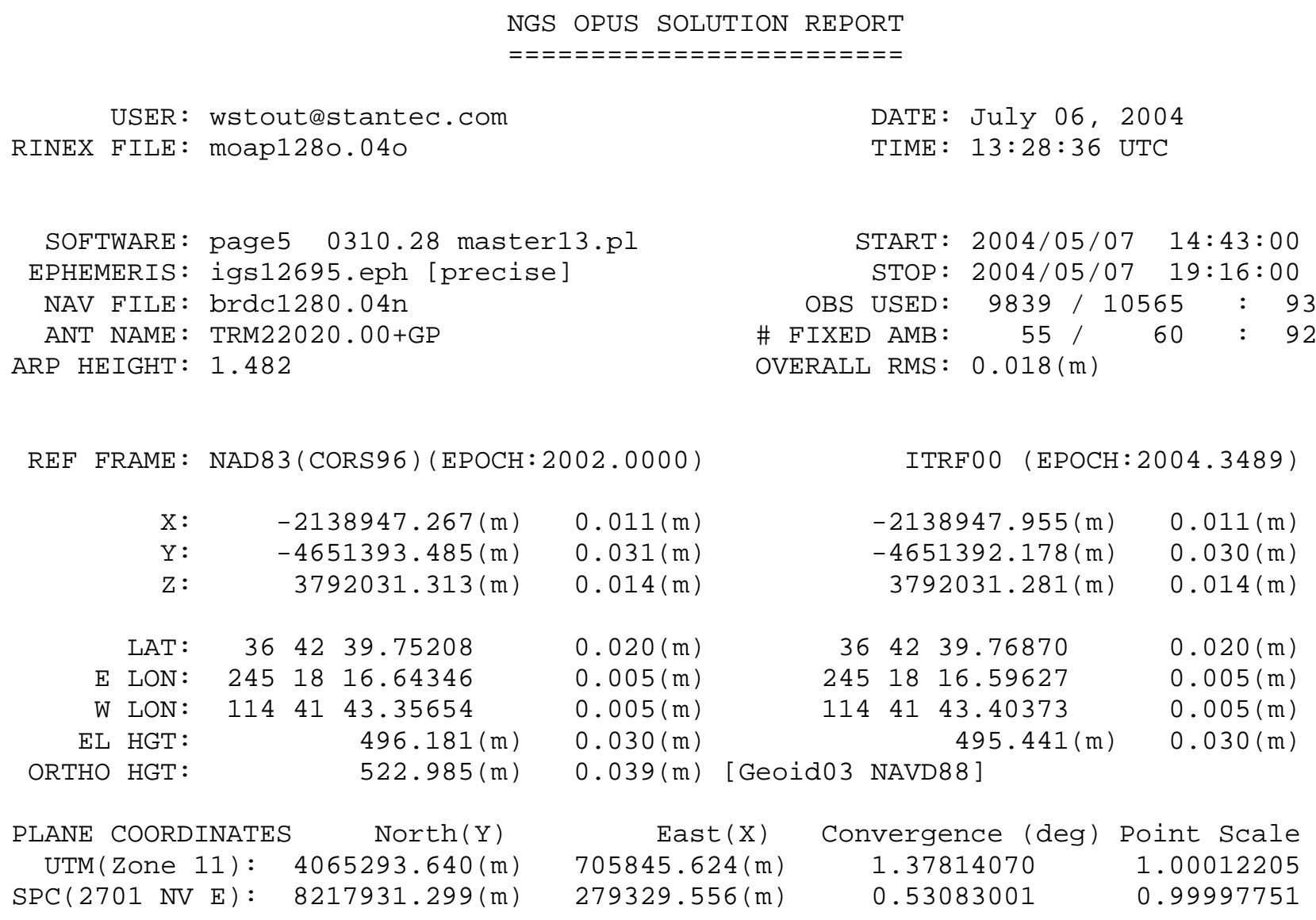

US NATIONAL GRID DESIGNATOR: 11SQA0584665294(NAD 83)

\begin{tabular}{lccccc}
\multicolumn{7}{c}{ BASE STATIONS USED } \\
PID & DESIGNATION & LATITUDE & LONGITUDE DISTANCE $(\mathrm{m})$ \\
AJ1826 & LVWD LAS VEGAS VALLEY CORS ARP & N360934.026 & W1151128.797 & 75663.6 \\
AI8817 & ECHO ECHO CANYON S.P. CORS ARP & N375455.904 W1141551.242 & 139059.9 \\
AM7015 KING KINGMAN CORS ARP & N351150.480 W1140229.275 & 178031.7 \\
\multicolumn{5}{c}{ NEAREST NGS PUBLISHED CONTROL POINT } \\
GR0789 & K 301 & N364305. & W1144136.
\end{tabular}

This position was computed without any knowledge by the National Geodetic Survey regarding the equipment or field operating procedures used. 


\section{WSBM-10 L.D.S. East Well}

FILE: LDSE1360.020 000181207 WSBM-10 L.D.S. EAST WELL

NGS OPUS SOLUTION REPORT

=ニニ=ニニニニニ=ニニニ=ニニニニニニニニニ=

USER: timothy.wolf \@lvvwd.com

RINEX FILE: ldse1360.020

LDS East

SOFTWARE: page 50203.19

EPHEMERIS: igs11664.eph [precise]

NAV FILE: brdc1360.02n

ANT NAME: TRM39105.00

ARP HEIGHT: 2.045

REF FRAME: NAD83(CORS96)(EPOCH: 2002.0000)

$X: \quad-2139830.827(\mathrm{~m})$

$\mathrm{Y}: \quad-4650119.731(\mathrm{~m})$

Z: $\quad 3793106.491(\mathrm{~m})$

LAT: $\quad \begin{array}{lll}36 & 43 & 22.98995\end{array}$

E LON: 2451722.85263

W LON: $114 \quad 42 \quad 37.14737$

EL HGT: $\quad 507.381(\mathrm{~m})$

ORTHO HGT: $\quad 534.195(\mathrm{~m})$

UTM: $\quad$ Zone 11

NORTHING: $\quad 4066594.241(\mathrm{~m})$

EASTING: $\quad 704478.975(\mathrm{~m})$

SPC: $\quad$ Zone 2701(NV)

NORTHING: $\quad$ 8219251.782(m)

EASTING: $\quad 277982.483(\mathrm{~m})$ $\odot .012(\mathrm{~m})$

$0.041(\mathrm{~m})$

$0.028(\mathrm{~m})$

$\odot .028(\mathrm{~m})$

$0.007(\mathrm{~m})$

$0.007(\mathrm{~m})$

$0.045(\mathrm{~m})$

$0.051(\mathrm{~m})$
DATE: June 20, 2002

TIME : $\odot \odot: 49: 18$ UTC

START: $2002 / 05 / 16 \quad 16: 39: 00$

STOP: $2002 / 05 / 16 \quad 18: 48: 00$

OBS USED: $4462 / 4699$ : $95 \%$

\# FIXED AMB: $29 / 31: 94 \%$

OVERALL RMS: $\odot . \odot 2 \odot(\mathrm{m})$

\section{BASE STATIONS USED}

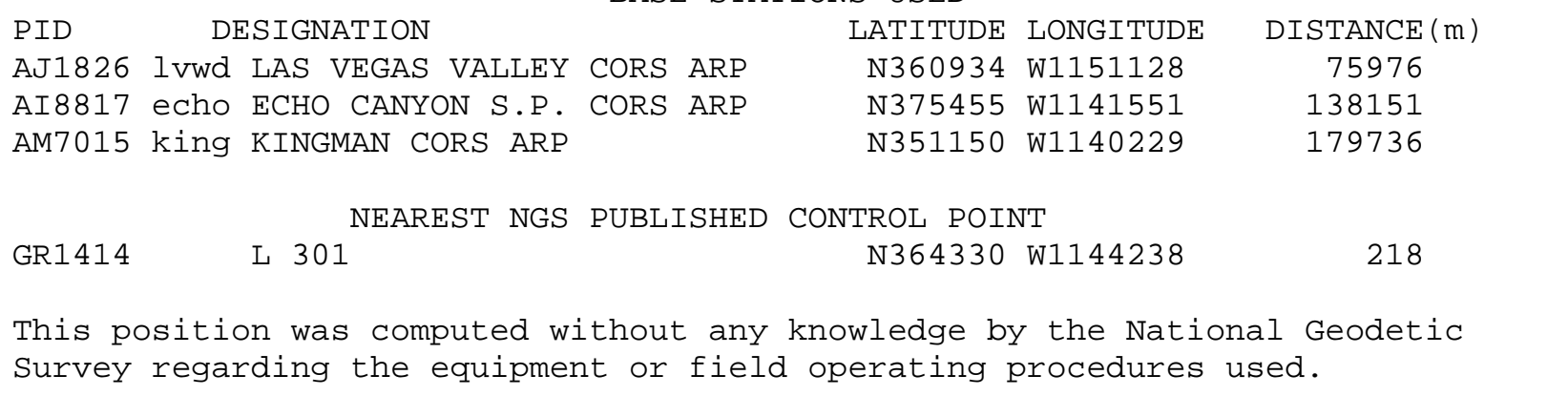

ITRFO९ (EPOCH:2002.3719)

$$
\begin{array}{rr}
-2139831.473(\mathrm{~m}) & 0.011(\mathrm{~m}) \\
-4650118.428(\mathrm{~m}) & 0.041(\mathrm{~m}) \\
3793106.474(\mathrm{~m}) & 0.028(\mathrm{~m})
\end{array}
$$

$\begin{array}{lll}36 & 43 & 23.00722\end{array}$

$\odot .028(\mathrm{~m})$

$\begin{array}{lll}245 & 17 & 22.80702\end{array}$

$\begin{array}{lll}114 & 42 & 37.19298\end{array}$ $506.639(\mathrm{~m})$

$0.009(\mathrm{~m})$

$\odot .009(\mathrm{~m})$

$0.045(\mathrm{~m})$

[Geoid99 NAVD88] 


\section{WSBM-11 L.D.S. Gage}

FILE：LDSG1340.020 000181206 WSBM-11 L.D.S. GAGE

NGS OPUS SOLUTION REPORT

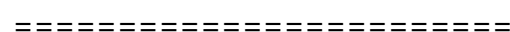

USER: timothy.wolf \@lvvwd.com

RINEX FILE: ldsg1340.020 LDS Gage

SOFTWARE: page5 0203.19

EPHEMERIS: igs11662.eph [precise]

NAV FILE: brdc1340.02n

ANT NAME: TRM39105.00

ARP HEIGHT: 2.045

REF FRAME: NAD83(CORS96)(EPOCH : 2002.0000)

$$
\begin{array}{lr}
X: & -2140313.027(\mathrm{~m}) \\
Y: & -4650051.452(\mathrm{~m}) \\
\mathrm{Z}: & 3792916.802(\mathrm{~m})
\end{array}
$$

$0.013(\mathrm{~m})$

$0.025(\mathrm{~m})$

$0.002(\mathrm{~m})$

LAT: $\quad \begin{array}{lll}36 & 43 & 15.35091\end{array}$

E LON: $24517 \quad 4.05180$

W LON: 1144255.94820

EL HGT:

ORTHO HGT:

$505.831(\mathrm{~m})$

$532.642(\mathrm{~m})$

$0.019(\mathrm{~m})$

$0.005(\mathrm{~m})$

$0.005(\mathrm{~m})$

$0.021(\mathrm{~m})$

$\odot .033(\mathrm{~m})$
DATE: June 20, 2002

TIME : $0 \odot: 44: 33$ UTC

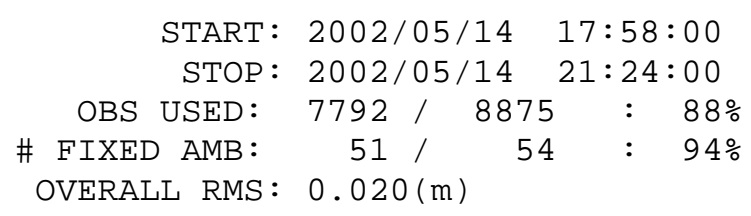

START: $2002 / 05 / 14 \quad 17: 58: 00$

STOP: $2002 / 05 / 14$ 21:24:00 OBS USED: $7792 / 8875: 88 \%$ \# FIXED AMB: $51 / 54: 94 \%$ OVERALL RMS: $\odot .020(\mathrm{~m})$

ITRFO९ (EPOCH: 2002.3666)

$$
\begin{array}{rr}
\text { UTM: } & \text { Zone } 11 \\
\text { NORTHING : } & 4066347.663(\mathrm{~m}) \\
\text { EASTING: } & 704018.131(\mathrm{~m}) \\
\text { SPC: } & \text { Zone } 2701(\mathrm{NV}) \\
\text { NORTHING : } & 8219012.081(\mathrm{~m}) \\
\text { EASTING : } & 277518.107(\mathrm{~m})
\end{array}
$$

BASE STATIONS USED

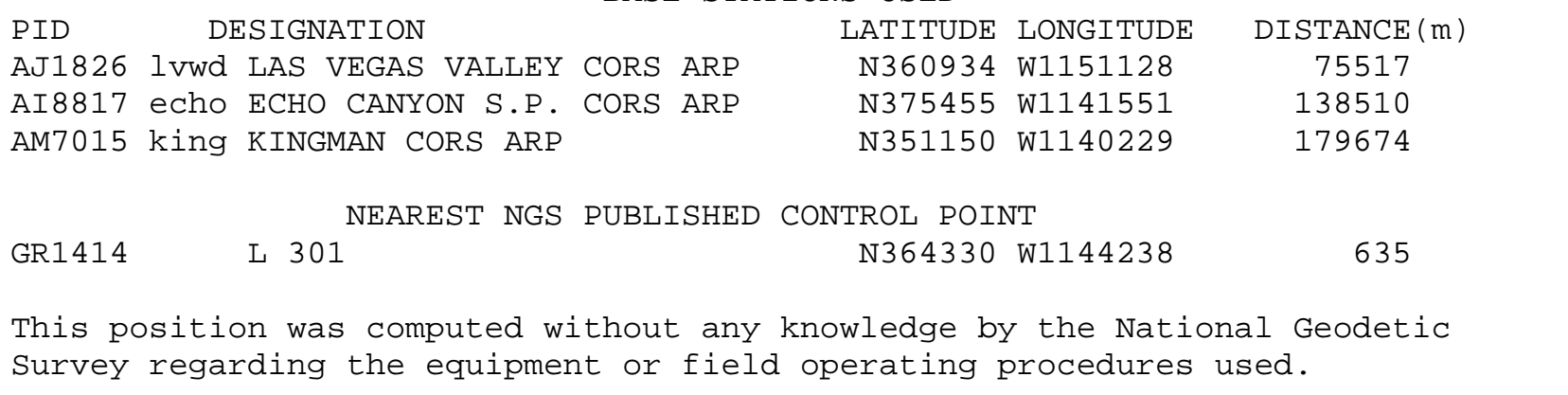




\section{WSBM-11 L.D.S. Gage}

WSBM-11 L.D.S. GAGE
REF FRAME: NAD83(CORS96) (EPOCH : 2002. .๑०९)
DATE: June 30,2004

TIME : 21:09:39 UTC
START: $20 \odot 4 / 06 / 02 \quad 17: 36: 0 \odot$ STOP: $2004 / 06 / 03 \quad 16: 02: 00$ OBS USED: 35159 / 37598 :

\# FIXED AMB: $164 / 192$ :

OVERALL RMS: $0.022(\mathrm{~m})$

\begin{tabular}{|c|c|c|c|c|c|c|c|}
\hline & $X:$ & \multicolumn{2}{|r|}{$-2140313.037(\mathrm{~m})$} & $\odot .001(\mathrm{~m})$ & \multicolumn{2}{|r|}{$-2140313.726(\mathrm{~m})$} & $\odot .001(\mathrm{~m})$ \\
\hline & Y: & & $-4650051.484(\mathrm{~m})$ & $\odot . \odot \odot 8(m)$ & & $-4650050.176(\mathrm{~m})$ & $\odot . \odot \odot 8(\mathrm{~m})$ \\
\hline & Z: & & $3792916.800(\mathrm{~m})$ & $\odot .006(\mathrm{~m})$ & & $3792916.767(\mathrm{~m})$ & $0.006(\mathrm{~m})$ \\
\hline & LAT : & 36 & 4315.35021 & $0.003(\mathrm{~m})$ & & 4315.36681 & $\odot .003(\mathrm{~m})$ \\
\hline $\mathrm{E}$ & LON : & 245 & 4.05198 & $\odot .0 \odot 4(\mathrm{~m})$ & 245 & $17 \quad 4.00472$ & $\odot .0 \odot 4(\mathrm{~m})$ \\
\hline W & LON : & 114 & 4255.94802 & $\odot .0 \odot 4(\mathrm{~m})$ & 114 & $42 \quad 55.99528$ & $0.004(\mathrm{~m})$ \\
\hline$E L$ & HGT : & & $505.856(\mathrm{~m})$ & $\odot .009(\mathrm{~m})$ & & $505.115(\mathrm{~m})$ & $\odot .008(\mathrm{~m})$ \\
\hline ORTHO & HGT: & & $532.593(\mathrm{~m})$ & $\odot .026(\mathrm{~m}) \quad[\mathrm{Geoj}$ & $d 03 N$ & NAVD88] & \\
\hline LANE C & & VATES & $S \quad \operatorname{North}(\mathrm{Y})$ & East $(X)$ & Conv & vergence (deg) & Point Scale \\
\hline UTM(Z & Zone 1 & & $4066347.642(\mathrm{~m})$ & $704018.136(\mathrm{~m})$ & & 1.36639033 & 1.00011282 \\
\hline $\operatorname{SPC}(270$ & $01 \mathrm{NV}$ & E): & $8219012.059(\mathrm{~m})$ & $277518.111(\mathrm{~m})$ & & ๑. 51889441 & $\odot .99997401$ \\
\hline
\end{tabular}

US NATIONAL GRID DESIGNATOR: 11SQA@401866348(NAD 83)

\section{BASE STATIONS USED}

$\begin{array}{lllll}\text { PID } & \text { DESIGNATION } & \text { LATITUDE } & \text { LONGITUDE DISTANCE }(\mathrm{m}) \\ \text { AJ1826 } & \text { LVWD LAS VEGAS VALLEY CORS ARP } & \text { N360934.026 } & \text { W1151128.797 } & 75516.6 \\ \text { DG4673 NVCS CARLTON SQUARE CORS ARP } & \text { N361311.196 } & \text { W1151019.335 } & 69046.4 \\ \text { DG4263 NVLK A M SMITH WTF CORS ARP } & \text { N360410.758 W1144847.501 } & 72803.4\end{array}$

\begin{tabular}{lrrrr}
\multicolumn{2}{c}{ NEAREST NGS PUBLISHED CONTROL POINT } \\
GR1414 301 & N364330.247 W1144238.752 & 627.6
\end{tabular}

This position was computed without any knowledge by the National Geodetic Survey regarding the equipment or field operating procedures used. 


\section{WSBM-12 Baldwin Flume}

FILE: BF011551.๑40 $\odot 00184853$

WSBM-12 BALDWIN FLUME

\section{NGS OPUS SOLUTION REPORT}

\section{ニニニニニニニニニニニニニニニニニニニニニニニニ}

USER: harper@usgs.gov

RINEX FILE: bf01155q.040
DATE: June 30, 2004

TIME : 21:10:27 UTC
SOFTWARE: page5 0310.28 master16.pl

EPHEMERIS: igs12734.eph [precise]

NAV FILE: brdc1550.04n $99 \%$

ANT NAME: ASH701975.01B

$99 \%$

ARP HEIGHT: 1.571906808

REF FRAME: NAD83(CORS96)(EPOCH:2002.0000)

$X: \quad-2140792.871(\mathrm{~m})$

$Y: \quad-4649818.555(\mathrm{~m})$

$\mathrm{Z}: \quad 3792942.552(\mathrm{~m})$

LAT: $\quad \begin{array}{lll}36 & 43 & 16.23194\end{array}$

E LON: $24516 \quad 42.56429$

W LON: $11443 \quad 17.43571$

EL HGT:

ORTHO HGT:

$512.486(\mathrm{~m})$

$539.212(\mathrm{~m})$ $0.009(\mathrm{~m})$

$\odot .010(\mathrm{~m})$

$0.004(\mathrm{~m})$

$\odot .009(\mathrm{~m})$

$\odot .008(\mathrm{~m})$

$\odot .008(\mathrm{~m})$

$0.006(\mathrm{~m})$

$0.026(\mathrm{~m})$

\author{
START: $2004 / 06 / 03 \quad 16: 19: 00$ \\ STOP: $2004 / 06 / 04$ 16:18:00 \\ OBS USED: $50723 / 51143$ : \\ \# FIXED AMB: $157 / 158$ : \\ OVERALL RMS: $\odot .015(\mathrm{~m})$
}

ITRFO९ (EPOCH : 2004.4240)

$$
\begin{array}{rr}
-2140793.561(\mathrm{~m}) & 0.009(\mathrm{~m}) \\
-4649817.248(\mathrm{~m}) & 0.010(\mathrm{~m}) \\
3792942.519(\mathrm{~m}) & 0.003(\mathrm{~m})
\end{array}
$$

$\begin{array}{llll}36 & 43 & 16.24851 & 0.009(\mathrm{~m})\end{array}$

$\begin{array}{llll}245 & 16 & 42.51701 & 0.008(\mathrm{~m})\end{array}$

$\begin{array}{lll}114 & 43 & 17.48299\end{array}$

$\odot .008(\mathrm{~m})$ $511.746(\mathrm{~m})$

$\odot .006(\mathrm{~m})$

Geoid03 NAVD88]

$\begin{array}{lcccc}\text { PLANE COORDINATES } & \text { North }(\mathrm{Y}) & \text { East }(\mathrm{X}) & \text { Convergence (deg) } & \text { Point Scale } \\ \text { UTM(Zone 11): } & 4066362.117(\mathrm{~m}) & 703484.353(\mathrm{~m}) & 1.36282560 & 1.00011014 \\ \text { SPC }(2701 \text { NV E }): & 8219034.425(\mathrm{~m}) & 276984.675(\mathrm{~m}) & 0.51532798 & 0.99997299\end{array}$

US NATIONAL GRID DESIGNATOR: 11SQA0348466362(NAD 83)

BASE STATIONS USED
PID
DESIGNATION
LATITUDE LONGITUDE DISTANCE $(\mathrm{m})$
AJ1826 LVWD LAS VEGAS VALLEY CORS ARP
N360934.026 W1151128.797
75238.1
N361311.196 W1151019.335
68752.7
DG4263 NVLK A M SMITH WTF CORS ARP
N360410.758 W1144847.501
72768.0
GR1414

$$
\text { L } 301
$$
NEAREST NGS PUBLISHED CONTROL POINT
This position was computed without any knowledge by the National Geodetic
Survey regarding the equipment or field operating procedures used. 


\section{WSBM-13 M-10}

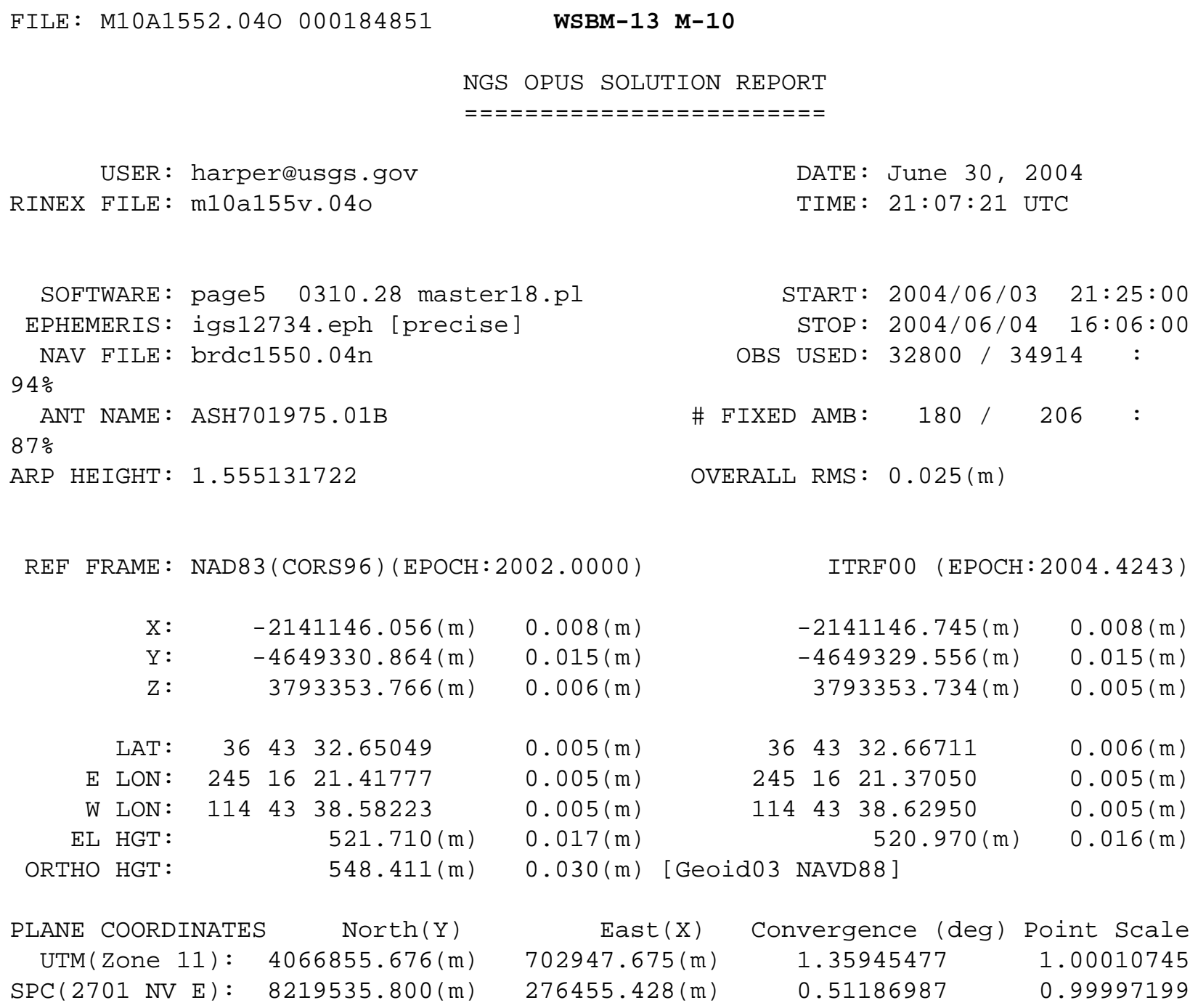

US NATIONAL GRID DESIGNATOR: 11SQAO294866856(NAD 83)

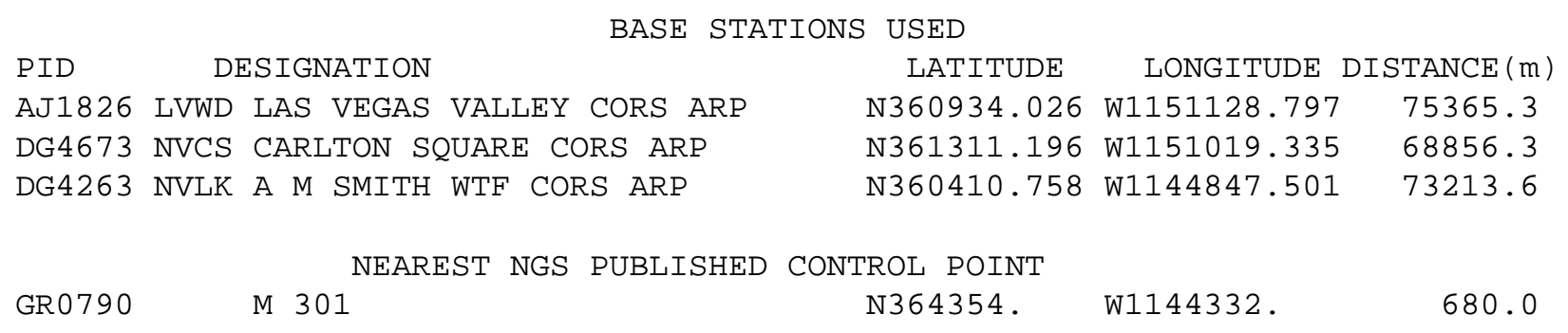

This position was computed without any knowledge by the National Geodetic Survey regarding the equipment or field operating procedures used. 

Appendix D. Discharge and Water-Quality Data Collected by the U.S. Geological Survey During September 10-12, 1963, in the Warm Springs Area Near Moapa, Nevada 
222 Water-Surface Elevations, Discharge, and Water-Quality Data in the Warm Springs Area near Moapa, Nevada

This page left intentionally blank. 


\section{WSBM-1 Jones Spring Box}

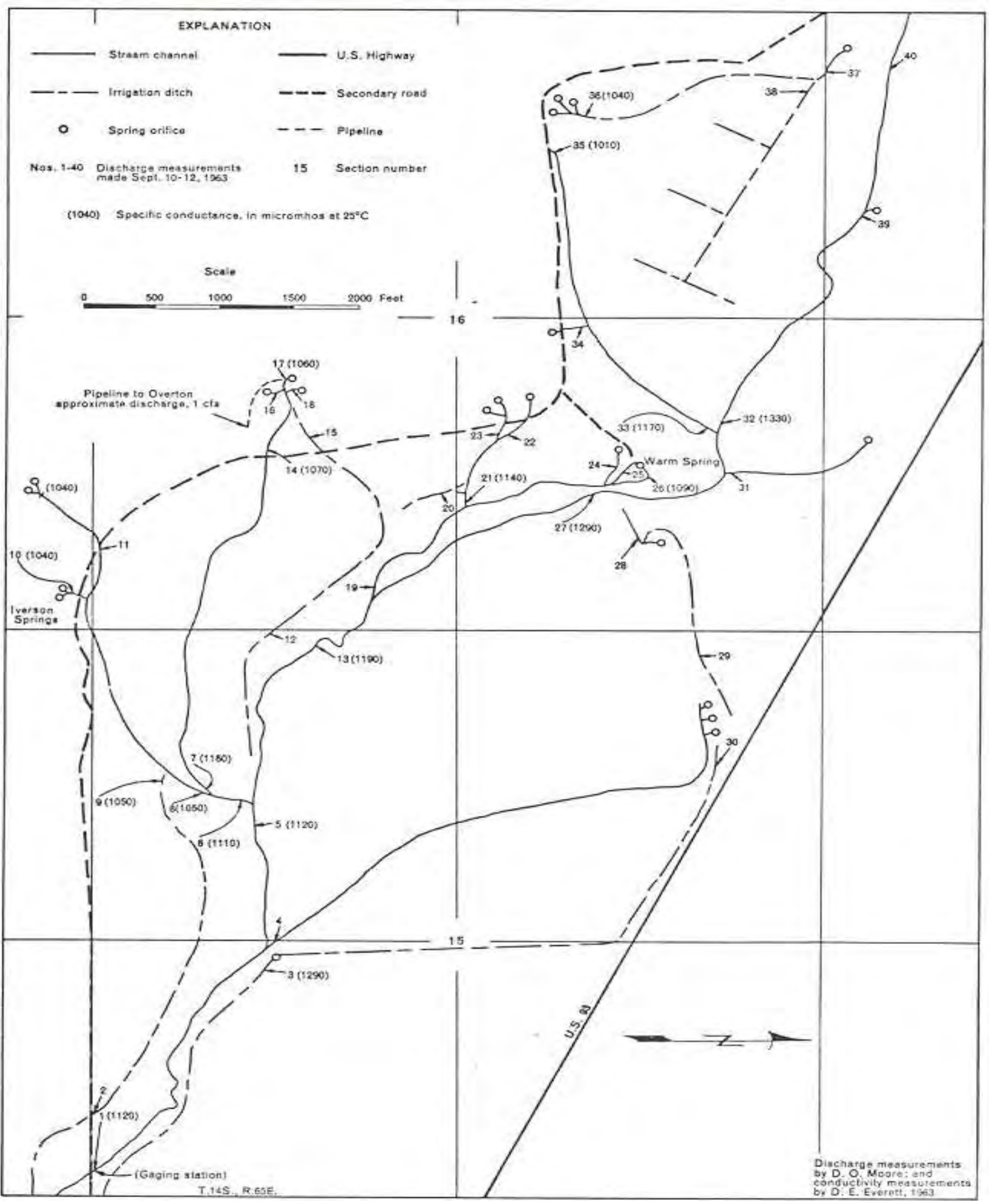

Figure D1. Sketch map showing location of discharge measurement sites in the Warm Springs area, September 12, 1963. (From Eakin, 1964.) 
Table D1. Index of discharge and specific-conductance measurements in the Warm Springs area, September 10-12, 1963. TableD1 data are available in an Excel data base for download at URL: http://pubs.water.usgs.gov/ofr2006-1311. 
Appendix E. Discharge and Water-Quality Data Collected by the U.S. Geological Survey, U.S. Fish and Wildlife Service, Nevada Division of Water Resources, and Southern Nevada Water Authority on February 6-7, 2001, in the Warm Springs Area Near Moapa, Nevada 
226 Water-Surface Elevations, Discharge, and Water-Quality Data in the Warm Springs Area near Moapa, Nevada

This page left intentionally blank. 
Table E1. Index of discharge and water-quality measurement sites in the Warm Springs area, near Moapa, Nevada. TableE1 data are available in an Excel data base for download at URL: http://pubs.water.usgs.gov/ofr2006-1311. 
Table E2. Discharge measurements made on February 7, 2001, in the Warm Springs area near Moapa, Nevada.

TableE2 data are available in an Excel data base for download at URL: http://pubs.water.usgs.gov/ofr2006-1311. 
Table E3. Water-quality data collected on February 6-7, 2001, in the Warm Springs area near Moapa, Nevada.

$\underline{\text { TableE3 }}$ data are available in an Excel data base for download at URL: http://pubs.water.usgs.gov/ofr2006-1311. 
This page left intentionally blank. 
Manuscript approved for publication, September 27, 2006

Prepared by the USGS Publishing Network,

Publishing Service Center, Tacoma, Washington

Bill Gibbs

Debra Grillo

Bobbie Jo Richey

Linda Rogers

Sharon Wahlstrom

Publishing Service Center, Sacramento, California

Myrna DeBortoli

Mary Gibbs

For more information concerning the research in this report, contact the

Director, Nevada Water Science Center

U.S. Geological Survey, 2730 N. Deer Run Road

Carson City, Nevada 89701

http://nv.water.usgs.gov 


\section{$\mathbb{Z}$ 蛋}

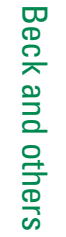

丽

옴

密 它

ल

需

三

㝘 흏

옳

동므.

cos

홍 흉

ํㅗㅇ

ำ

쪽 옥

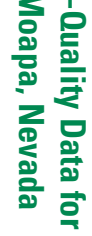

욱

옹 